\title{
Nicholas of Cusa and Islam
}

\section{Polemic and Dialogue \\ in the Late Middle Ages}

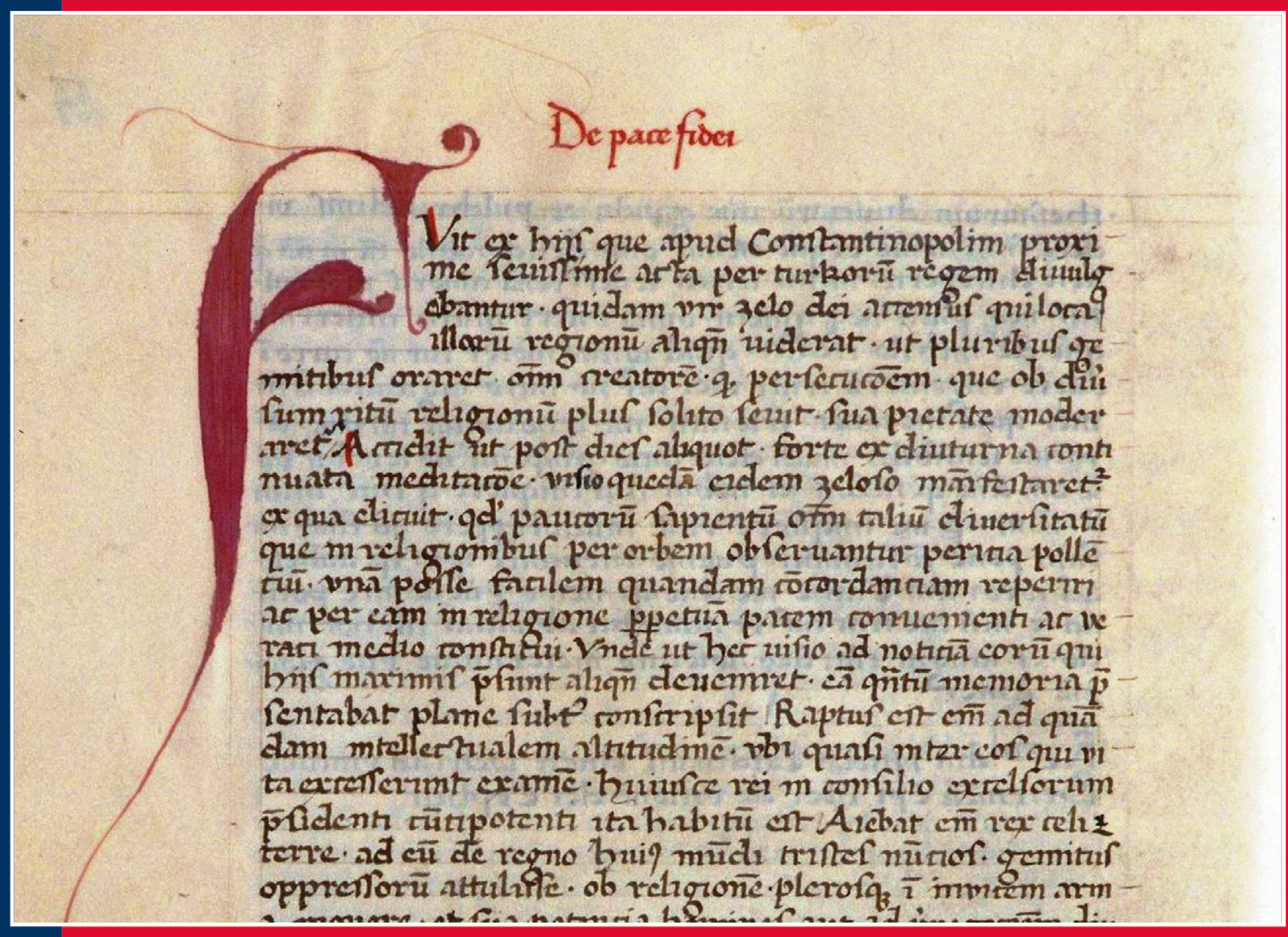

Edited by

Ian Christopher Levy,

Rita George-Tvrtković $\sigma$

Donald F. Duclow

B R I L L 
Nicholas of Cusa and Islam 


\title{
Studies in Medieval and Reformation Traditions
}

\author{
Edited by \\ Andrew Colin Gow (Edmonton, Alberta) \\ In cooperation with \\ Sylvia Brown (Edmonton, Alberta) \\ Falk Eisermann (Berlin) \\ Berndt Hamm (Erlangen) \\ Johannes Heil (Heidelberg) \\ Susan C. Karant-Nunn (Tucson, Arizona) \\ Martin Kaufhold (Augsburg) \\ Erik Kwakkel (Leiden) \\ Jürgen Miethke (Heidelberg) \\ Christopher Ocker (San Anselmo and Berkeley, California)
}

Founding Editor

Heiko A. Oberman †

VOLUME 183

The titles published in this series are listed at brill.com/smrt 


\title{
Nicholas of Cusa and Islam
}

Polemic and Dialogue in the Late Middle Ages

\author{
Edited by
}

Ian Christopher Levy

Rita George-Tvrtković

Donald F. Duclow

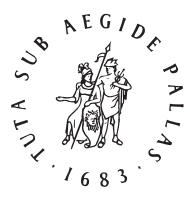

B R I L L 
This is an open access title distributed under the terms of the CC BY-NC 4.0 license, which permits any non-commercial use, distribution, and reproduction in any medium, provided the original author(s) and source are credited. Further information and the complete license text can be found at https://creativecommons.org/licenses/ by-nc/4.0/

The terms of the cc license apply only to the original material. The use of material from other sources (indicated by a reference) such as diagrams, illustrations, photos and text samples may require further permission from the respective copyright holder.

An electronic version of this book is freely available, thanks to the support of libraries working with Knowledge Unlatched. More information about the initiative can be found at www. knowledgeunlatched.org.

Cover illustration: Opening leaf of 'De pace fidei' in Codex Cusanus 219, fol. 24v. (April-August 1464). Photo: Erich Gutberlet / @ St. Nikolaus-Hospital/Cusanusstift, Bernkastel-Kues, Germany.

Library of Congress Cataloging-in-Publication Data

Nicholas of Cusa and Islam : polemic and dialogue in the late Middle Ages / edited by Ian Christopher Levy, Rita George-Tvrtkovic, Donald F. Duclow. pages cm. - (Studies in medieval and Reformation traditions, ISSN 1573-4188 ; VOLUME 183) Includes index.

ISBN 978-90-04-27475-4 (hardback : alk. paper) — ISBN 978-90-04-27476-1 (e-book) 1. Nicholas, of Cusa, Cardinal, 1401-1464. 2. Islam-Controversial literature-Early works to 1800. 3. Qur'an-Criticism, interpretation, etc.-Early works to 1800. 4. Islam—Relations-Christianity-Early works to 1800.

5. Christianity and other religions-Islam-Early works to 1800. 6. Nicholas, of Cusa, Cardinal, 1401-1464. De pace fidei. 7. Nicholas, of Cusa, Cardinal, 1401-1464. Cribratio Alkorani. I. Levy, Ian Christopher, editor of compilation.

BX4705.N58N49 2014

$261.2 ' 7092-\mathrm{dc} 23$

This publication has been typeset in the multilingual "Brill" typeface. With over 5,100 characters covering Latin, IPA, Greek, and Cyrillic, this typeface is especially suitable for use in the humanities.

For more information, please see www.brill.com/brill-typeface.

ISSN 1573-4188

ISBN 978-90-04-27475-4 (hardback)

ISBN 978-90-04-27476-1 (e-book)

Copyright 2014 by the Authors. Published by Koninklijke Brill NV, Leiden, The Netherlands.

Koninklijke Brill NV incorporates the imprints Brill, Brill Nijhoff, Global Oriental and Hotei Publishing. All rights reserved. No part of this publication may be reproduced, translated, stored in a retrieval system, or transmitted in any form or by any means, electronic, mechanical, photocopying, recording or otherwise, without prior written permission from the publisher.

Authorization to photocopy items for internal or personal use is granted by Koninklijke Brill NV provided that the appropriate fees are paid directly to The Copyright Clearance Center, 222 Rosewood Drive, Suite 910, Danvers, MA 01923, USA. Fees are subject to change.

This book is printed on acid-free paper. 



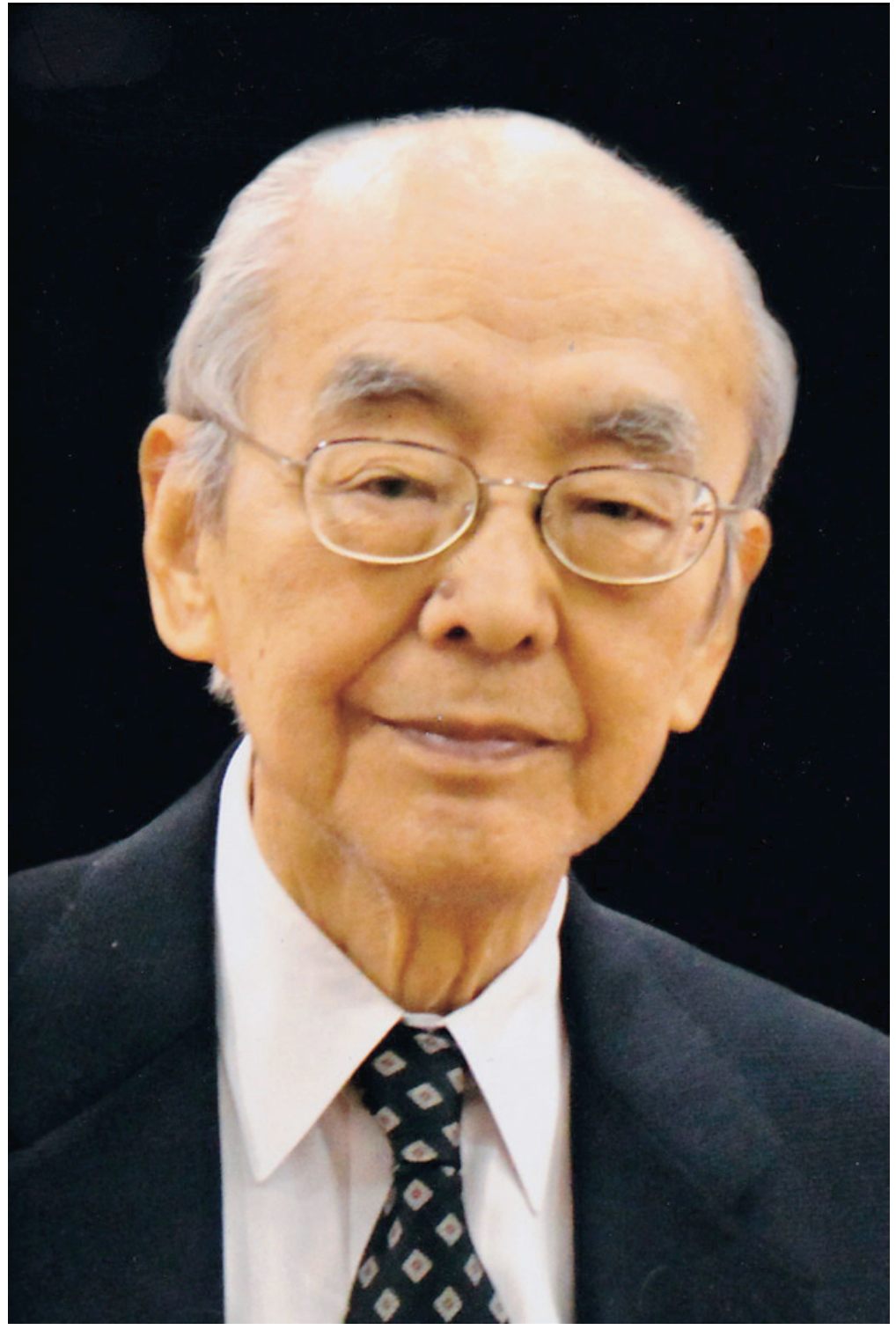

Morimichi Watanabe (1926-2012) 


\section{Dedication}

We dedicate this volume to the memory of Morimichi Watanabe (1926-2012). In virtue of his scholarship and organizational skills, Mori was the dean of Cusanus studies in America. His research centered on Cusanus from his first book, The Political Ideas of Nicholas of Cusa, with Special Reference to De concordantia catholica (Droz, 1963), up to his last, Nicholas of Cusa: A Companion to His Life and His Times (Ashgate, 2011). Mori also guided the American Cusanus Society as its President for twenty-five years (1983-2008), and remained active as President Emeritus and editor of the Society's Newsletter until his death. For his vision and persuasive leadership, Mori was affectionately known as the Society's Shogun - a title that he resisted, but that would not go away because the evidence was simply too strong. Under his leadership, the Society grew from an informal group sponsoring Cusanus sessions at the International Congress on Medieval Studies in Kalamazoo into an organization with an internationally prized Newsletter, a vigorous publication program, and biennial conferences at the Lutheran Theological Seminary at Gettysburg. The 2012 Gettysburg conference on "Christian-Muslim Dialogue in the Late Middle Ages" was also dedicated to Mori. Both the conference and this book continue his life-long work as a scholar and the guiding genius of the American Cusanus Society. Indeed, our book witnesses to this legacy by publishing Mori's article "Cusanus, Islam, and Religious Tolerance" at the start of Part I. This is especially fitting since Mori was thinking and writing about these issues long before the rest of us. As he notes with characteristic modesty, the article revisits the themes of a paper he presented at the landmark 1964 Cusanus conference in Bressanone, though he hopes that he has "gained more insight into the subject since that time." The article leaves no doubt on this score. Mori wrote it for the 2003 meeting of the Japanese Cusanus Society, and later translated it into English. It appears here in print for the first time. 



\section{Contents}

List of Contributors ix

Foreword by Thomas E. Burman: Nicholas of Cusa and Peter the Venerable's

Request xiii

Editors' Introduction $\quad 1$

\section{PART 1}

Cusanus and Islam

Cusanus, Islam, and Religious Tolerance $\quad 9$

Morimichi Watanabe

A Critical Survey of Cusanus's Writings on Islam 20

Walter Andreas Euler

Una Religio in Rituum Varietate: Religious Pluralism, the Qur'an, and Nicholas of Cusa $\quad 30$

Pim Valkenberg

Divine Difference and Religious Unity: On the Relation Between

De Docta Ignorantia, De Pace Fidei and Cribratio Alkorani 49

Knut Alfsvåg

Reading De pace fidei Christologically: Nicholas of Cusa's Verbum Dialectic of Religious Concordance $\quad 68$

Joshua Hollmann

The Trinity as a Challenge to Christian-Muslim Dialogue: Nicholas of

Cusa's Philosophical Translation of Trinitarian Faith as a Response to Islamic Rejection $\quad 86$

Felix Resch 


\section{PART 2 \\ Historical Perspectives}

Deficient Sacraments or Unifying Rites? Alan of Lille, Nicholas of Cusa, and Riccoldo da Montecroce on Muslim and Jewish Praxis $\quad 105$

Rita George-Tvrtković

Perspectives on Islam in Italy and Byzantium in the Middle Ages and Renaissance 123

Marica Costigliolo

Juan de Segovia on the Superiority of Christians over Muslims:

Liber de magna auctoritate episcoporum in concilio generali 10.6 Jesse D. Mann

How to Deal with Muslims? Raymond Lull and Ignatius of Loyola 160 Paul Richard Blum

PART 3

Muslim Responses to Christianity

The Messiah 'Isa, Son of Mary: Jesus in the Islamic Tradition $\quad 179$ Asma Afsaruddin

Revisiting the Charge of Tahrīf: The Question of Supersessionism in Early Islam and the Qurān $\quad 202$ Sandra Toenies Keating

Ibn Ḥazm's and al-Ghazzālī's Most Divergent Responses to Christianity: A Question of Epistemology and Hermeneutics $\quad 218$ Tamara Albertini

Jesus in the Muslim and Christian Mystical Traditions: Ibn 'Arabi and Meister Eckhart 235

RobertJ. Dobie

Index of Names and Terms 253 


\section{List of Contributors}

\section{Asma Afsaruddin}

is Professor of Islamic Studies and Chairperson of the Department of Near Eastern Languages and Cultures at Indiana University, Bloomington. She is the author and/or editor of six books, including Striving in the Path of God: Jihad and Martyrdom in Islamic Thought (Oxford: Oxford University Press, 2013) and The First Muslims: History and Memory (Oxford: OneWorld Publications, 2008). Her research has been funded by, among others, the Harry Frank Guggenheim Foundation and the Carnegie Corporation of New York, which named her a Carnegie Scholar in 2005.

\section{Tamara Albertini}

is Professor of Philosophy at the University of Hawai'i at Manoa, specializing in Renaissance and Islamic thought. She is also the Director of the Islamic Studies Certificate. Within Islamic philosophy her publications include: "Mystical Landscapes_-Places of the Mind. Emptiness and Plenitude in Islamic Philosophy," in Labirinti della mente, ed. Grazia Marchianò (2012); "Crisis and Certainty of Knowledge in al-Ghazzali and Descartes," Philosophy East and West (2005); and "The Seductiveness of Certainty. Fundamentalists' Destruction of Islam's Intellectual Legacy," Philosophy East and West (2003).

\section{Knut Alfsvåg}

was born in 1955 and graduated from the Norwegian School of Theology, Oslo. He is professor of systematic theology at the School of Mission and Theology, Stavanger, Norway, and has written on apophatic theology and the understanding of God.

\section{Paul Richard Blum}

is T. J. Higgins, S. J., Chair in Philosophy at Loyola University Maryland, Baltimore, USA. He obtained his PhD in Munich and his habilitation at Freie Universität Berlin. Among his recent publications are Giordano Buno-An Introduction (Amsterdam: Rodopi, 2012), Studies on Early Modern Aristotelianism (Leiden: Brill, 2012), and Philosophy of Religion in the Renaissance (Farnham: Ashgate, 2010).

\section{Thomas E. Burman}

is Distinguished Professor of the Humanities in the Department of History at the University of Tennessee, and is the author of Religious Polemic and the 
Intellectual History of the Mozarabs, 1050-1200 (Leiden: E.J. Brill, 1994) and Reading the Qur'an in Latin Christendom, 1040-1560 (Philadelphia: University of Pennsylvania Press, 2007), which won the American Philosophical Society's Jacques Barzun Prize for Cultural History. His research has been supported by fellowships from the Rockefeller Foundation (1992-93) and the National Endowment for the Humanities (2002-03, 2013-14). He is currently writing a book entitled The Dominicans, Islam, and Christian Thought, 1220-1320.

\section{Marica Costigliolo}

received her PhD in Political Thought at the University of Genoa. She is the author of Islam e cristianesimo: mondi di differenze nel Medioevo. Il dialogo con l'Islam nell'opera di Nicola da Cusa (Genova: Genova University Press, 2012). Her research is focused on the perception of otherness in Western culture.

\section{Donald F. Duclow}

is Professor of Philosophy Emeritus at Gwynedd-Mercy College. He is Secretary of the American Cusanus Society, and has published widely on the Christian Neoplatonic tradition in the Middle Ages. His book Masters of Learned Ignorance: Eriugena, Eckhart, Cusanus (Farnham: Ashgate, 2006) includes twenty of his articles.

\section{Walter Andreas Euler}

completed his Studies in Catholic Theology in Passau and Freiburg (1981-86), and his $\mathrm{PhD}$ at the University of Freiburg (1990). He has been the university lecturer of Cusanus Research at the Faculty of Theology in Trier (1992), Professor in Fundamental Theology and Ecumenical Theology at the Faculty of Theology in Trier (2001), Director of the Institute of Cusanus Research in Trier (2007), Chairman of the Scientific Advisory Board of the German Cusanus Society, and Member of the Board of Advisors of the American Cusanus Society. His publications treat matters of fundamental theology, Renaissance theology, and Nicholas of Cusa.

\section{Rita George-Tvrtković}

earned her PhD from the University of Notre Dame, and is Assistant Professor of Theology at Benedictine University in Illinois, where she specializes in historical theology and medieval Christian-Muslim relations. Her publications include the monograph A Christian Pilgrim in Medieval Iraq: Riccoldo da Montecroce's Encounter with Islam (Turnhout: Brepols, 2012). 


\section{Joshua Hollmann}

received his $\mathrm{PhD}$ from McGill University. He is Assistant Professor of Religion at Concordia College-New York. He has published essays on the thought of Nicholas of Cusa in Philosophy and the Abrahamic Religions: Scriptural Hermeneutics and Epistemology (Cambridge Scholars Publishing, 2012), Religion and Cultural Mediation in Early Modernity (Cambridge Scholars Publishing, 2013), and The Merton Annual, Volume 25 (2013).

\section{Sandra Toenies Keating}

is Associate Professor of Theology at Providence College. She earned her PhD at the Catholic University of America, and an STL at the Pontifical Institute for the Study of Islam and Arabic (PISAI) in Rome. She has published numerous articles and a book on Muslim-Christian relations, focusing specifically on the early centuries of Islam.

\section{Ian Christopher Levy}

is Associate Professor of Theology at Providence College in Providence, Rhode Island. His work focuses on medieval biblical exegesis, ecclesiology, and sacramental theology. His most recent book is Holy Scripture and the Quest for Authority at the End of the Middle Ages (Notre Dame: University of Notre Dame Press, 2012).

\section{Jesse D. Mann}

received his $\mathrm{PhD}$ from the University of Chicago. He is the author of numerous articles on Juan de Segovia and late medieval intellectual and ecclesiastical history. He is adjunct professor of Humanities at Montclair State University (Montclair, NJ).

\section{Felix Resch}

teaches Philosophy of Religion at the University of Freiburg, Germany, after having studied Philosophy and Theology at the Munich School of Philosophy, University of Trier, and Ibero-American University in Mexico City. His publications include his book Triunitas: Die Trinitätsspekulation des Nikolaus von Kues (Buchreihe der Cusanus-Gesellschaft; Münster: Aschendorff, 2014). 
Pim (Wilhelmus G.B.M.) Valkenberg

received his $\mathrm{PhD}$ in 1990 from the Catholic Theological University of Utrecht in the Netherlands, where he was born. After positions at the Catholic

University of Nijmegen and Loyola University in Maryland, he is currently an Ordinary Professor in the area of religion and culture at the Catholic University of America. Among his major publications are Words of the Living God (2000), The Three Rings (2005), and Sharing Lights on the Way to God (2006). His major field of research is Christian-Muslim relations, both in the medieval era and the present time. 


\section{Foreword by Thomas E. Burman: Nicholas of Cusa and Peter the Venerable's Request}

As the late Morimichi Watanabe points out later in this volume, Nicholas of Cusa wrote his remarkable Cribratio Alkorani, The Sifting of the Qur'an, in 1460-1461 at the request of his close friend, Pope Pius II (1458-1464). Yet I want to suggest here, at the beginning of a collection of essays about Cusanus and Islam, that we might just as well consider the Cribratio as the response to an invitation sent out more than three hundred years earlier, an invitation that had remained as of yet unfulfilled. For as a kind of preface to his well-known twelfth-century Latin anthology of Islamic texts, Peter the Venerable included a copy of a letter about the project that he had sent to Bernard of Clairvaux. After describing how he had located the various translators and organized their work, and after explaining that he had undertaken this project to insure that Christians recognize that Islam is the 'feces of all the heresies,' Peter writes that

I have notified you [Bernard] in particular about all this in order... to inspire your magnificence of learning - which God has uniquely bestowed on you in our days - to write against such a pernicious sect. ${ }^{1}$

This request tells us a great deal about Bernard's standing in Latin Christendom in the mid-twelfth century, but is otherwise a rather curious business-or so I have long thought. Peter had gone through all the trouble to arrange for fine linguists to translate Arabic texts into Latin, including the Qur'an and a wellinformed Arab-Christian apologetic work directed at Islam, and had done so in Spain since he knew that such translators and such texts could only be found there, but then turned immediately to a northern European abbot and asked him to write against Islam using the materials that he had made available in his

1 "Hoc ego de hoc precipuo errore errorum de hac faece universarum heresum, in quam omnium diabolicarum sectarum quae ab ipso Saluatoris aduentu ortae sunt reliquiae confluxerunt, facere volui, ut sicut ejus letali peste dimidius pene orbis infectus agnoscitur, ita quam exsecrandus et conculcandus detecta ejus stulticia et turpitudine a nescientibus agnoscatur.... Specialiter autem uobis haec omnia notificaui, ut et tanto amico studia nostra communicarem, et ad scribendum contra tam perniciosum errorem, illam uestram quam nostris diebus Deus uobis singulariter contulit doctrinae magnificentiam animarem." (Peter the Venerable, "Epistola Petris Cluniacensis ad Bernardum Claraevallis," in Peter the Venerable and Islam, ed. James Kritzeck (Princeton, N.J.: Princeton University Press, 1964), 212-14 at 213). 
influential anthology. Bernard was a towering intellect, to be sure, well known for his defense of orthodoxy, but why exactly approach him and not someone with much more immediate knowledge of Islam, such as one of the translators he had hired, or, say, Dominicus Gundassalinus, the Spanish Christian philosopher and Arabic-to-Latin translator? Moreover, what is equally intriguing is Bernard's complete disinterest in Peter's invitation: he never wrote anything remotely like a systematic refutation of Islam.

Peter's request, however, went unanswered not only in his own lifetime, but also, one might argue, for many generations thereafter. For indeed, Bernard's response to Peter's invitation foreshadowed that of nearly all the great thinkers-all those who were seen by contemporaries to have had 'magnificence of learning' bestowed upon them-of the later medieval Latin-Christian world. They similarly refused to take up the invitation to write against the 'pernicious sect' of Islam, until we arrive at the second half of the fifteenth century, with Nicholas of Cusa's lengthy writings on Islam. Indeed, if we page through the recently published volumes of the massive Christian-Muslim Relations: A Bibliographical History, ${ }^{2}$ we can't help but notice that most of the great scholastic thinkers-Abelard, Hugh of St. Victor, Peter Lombard, Albert the Great, Bonaventure, Duns Scotus, Ockham — are entirely absent. Important, indeed seminal, Latin treatises against Islam were being composed in the thirteenth and early fourteenth centuries, but they were the work of quirky, marginal, and often marginalized figures whom nobody considered the leading intellects of the age-men such as Ramon Martí, a brilliant Semitic linguist from Spain who wrote two short, learned works against Islam, but then turned his back on the 'Islamic question' and dedicated the bulk of his scholarly work to combating Judaism. Another such figure was his fellow Iberian, Raymond Lull, who was well aware that he seemed a crackpot (phantasticus) in his own time, despite his immense labors to learn Arabic and develop a complex philosophical system designed to convert Muslims (and everyone else) to properly reformed Latin Christianity. ${ }^{3}$ Richard Southern may have been correct in his argument that the purpose of the scholastic movement was to restore and systematize all knowledge for the purpose of reforming Christendom and defending it against its enemies, but for mainstream, northern scholastic thinkers in the high and later Middle Ages this did not mean actually writ-

2 David Thomas et al., eds., Christian-Muslim Relations: A Bibliographical History, 4 volumes published to date (Leiden-Boston: Brill, 2009-). Hereafter, $C M R$.

3 For the extensive bibliography on Martí and Lull, see respectively CMR 4, 381-90, 703-17. For Lull's frank self-assessment on the eve of the Council of Vienne in 1311, see his Phantasticus or Liber disputationis Petri et Raimundi, ссСм 78, 1-30. 
ing against the religion of Islam, as Peter the Venerable had asked Bernard of Clairvaux to do. ${ }^{4}$

Now it is true that a few scholastic thinkers do show up in the pages of the Christian-Muslim Relations bibliography. William of Auvergne (d. 1249) wrote against Islam in his De legibus, but the four relevant chapters hardly represent the sustained response that Peter seemed to have had in mind. Roger Bacon (d. after 1292), of course, also had much to say here and there about Muhammad and Islam in the Opus maius. Apart from them, however, scholastic authors did not find the refutation of Islamic belief and practice a compelling topic. ${ }^{5}$ Indeed, the closest thing to what Peter the Venerable was requesting - a wellinformed refutation of Islam by a leading northern European thinker-were his own two works on the subject. ${ }^{6}$

Of course, many have seen Thomas Aquinas' immense Summa contra gentiles as a treatise against Islam. This idea goes back to about a generation after his death, when the story began to circulate that Ramon de Penyafort, one-time master general of Aquinas' Dominican order, had asked him to write a manual for missionaries to Islam, to which Aquinas responded with his summa against whatever he meant by 'gentiles'. For many centuries this notion was widely accepted, and it has its defenders still. Yet on this issue, one must side with the series of modern scholars (including most prominently the late Dominican, René-Antoine Gauthier) who have argued that this certainly could not have been the case. ${ }^{7}$ Not only is the evidence for Penyafort's request suspect, but, as a whole, the Summa contra gentiles contains nothing that recommends it as a guidebook for real missionaries talking to real Muslims. Aquinas only mentions Islam nine times in the entire work, and only a brief paragraph (1.6) says anything remotely substantive about the religion. Here he sneers at Muhammad for attracting followers with promises of a carnal paradise, and claims that yes, Muhammad preached some true things, but only mixed together with fables and utterly false doctrines. Most importantly, however, having made utterly

4 Richard Southern, Scholastic Humanism and the Unification of Europe, vol. 1: Foundations (Oxford, u K-Cambridge, Mass: Blackwell, 1995), 4.

5 On William and Roger Bacon see CMR 4, 288-94, 457-70.

6 On which see $C M R 3$ [Dominique Iogna-Prat and John Tolan, "Peter of Cluny," in ChristianMuslim Relations. A Bibliographical History, General Editor David Thomas (Leiden: Brill Online, 2013). Accessed 28 May, 2013, http://referenceworks.brillonline.com/entries/christianmuslim-relations/peter-of-cluny-COM_24376].

7 He discusses this issue at a number of points in his many works, but comprehensively presents his views in his Somme contre les gentils: Introduction (Paris: Éditions Universitaires, 1993), passim, esp. 119-30. Here I take a position very different from John Tolan's in his article about Aquinas in $C M R$ 4, 521-29. 
clear a few paragraphs earlier (1.2) that his audience in writing the Summa contra gentiles was to be learned sages (sapientes), he pointedly asserts in the same short passage that Islam contained none: non aliqui sapientes, in rebus divinis et humanis excercitati, a principio crediderunt: sed homines bestiales in desertis morantes, omnis doctrinae divinae prorsus ignari. ${ }^{8}$

Moreover, though Aquinas suggests that he had read the Qur'an, which circulated in Latin within his own order, ${ }^{9}$ there is absolutely nothing in this work to suggest that he had actually done so. Indeed, Aquinas hardly thought at all about the religion that Muhammad preached. The fact that he was comfortable repeating overused Latin-Christian insults against Islam, as well as polemical arguments that he must have known were feeble, suggests that, as Gauthier put it, the problem of Islam "did not interest him at all." What Aquinas held up for careful, exacting criticism in the Summa contra gentiles was not "the errors of Muslim theologians ... [but] their philosophy."10

It is true that Aquinas engaged with Islam in one other work, the brief $D e$ rationibus fidei, which consists of the great Dominican's responses to questions sent to him by a contemporary confrere living in the Crusader States and known only as the 'Cantor of Antioch.' As Gabriel Said Reynolds has made clear, the questions that the cantor sent Aquinas are themselves precisely the sort of questions that real Muslims in the Middle East asked Christians. ${ }^{11}$ But since one of the key sources for De rationibus fidei is none other than the Summa contra gentiles, we will not be surprised to find that Aquinas answers these legitimate Muslim questions with ideas developed largely in response to ArabAristotelian philosophy, rather than Islamic beliefs. ${ }^{12}$ Furthermore, it is striking that later readers did not see this work as a treatise actually meant to convert

Thomas Aquinas, Opera omnia iussu impensaque Leonis XIII P. M. edita, t. 13: Summa contra gentiles 1.6 (Romae: Ex typographia polyglotta S. C. de Propaganda Fide, 1882), 17. "Nulla etiam divina oracula praecedentium prophetarum ei testimonium perhibent: quin potius quasi omnia veteris et novi testamenti documenta fabulosa narratione depravat, ut patet eius legem inspicienti" (ibid). On the circulation of the Qur'an among the Dominicans, see Thomas E. Burman, Reading the Qur'an in Latin Christendom, 1140-1560 (Philadelphia: University of Pennsylvania Press, 2007), 91-98, and id., "How an Italian Friar Read his Arabic Qur'an," Dante Studies 125 (2007): 93-109.

10 René-Antoine Gauthier, O.P., Somme contre les gentils: Introduction (Paris: Èditions Universitaires, 1993), 126-27.

11 Gabriel [Said] Reynolds, "Saint Thomas' Islamic Challenge: Reflections on the Antiochene Questions," Islam and Christian-Muslim Relations 12 (2001): 161-89.

12 Thomas Aquinas, Opera omnia iussu impensaque Leonis XIII P. M. edita, t. 40, pars b-c:De rationibus fidei (Romae: ad Santae Sabinae, 1968). On its connections with the Summa contra gentiles, see Jean-Pierre Torrell, O.P., Saint Thomas Aquinas, vol. 1: The Person and His Work, rev. ed., trans., Robert Royal (Washington, DC: The Catholic University of America Press, 2005), 124-25, 351-52. 
Muslims: none of the seventy-seven extant manuscripts (with the exception of one: Oviedo, Biblioteca del Cabildo, MS 24) are grouped together with any of the polemical and apologetic works of Ramon Martí, William of Tripoli, or Riccoldo da Monte di Croce, the three Dominican specialists in Arabic and the study of Islam whose works truly interrogated Islam and its holy book. ${ }^{13}$

What is true for Aquinas is true, I suggest, of scholastic philosophers and theologians in general in the thirteenth and fourteenth centuries. While there are plenty of signs that Islam was on the minds of Latin Christiansthe Quran, for example, circulated widely in two different Latin translations that were both read closely, as the frequent annotations in their margins sugges $\mathrm{t}^{14}$ - we nevertheless have little evidence of the leading schoolmen bothering with it. We can think of a variety of possible reasons for this: the university curriculum had no place for the investigation of Islam; unlike Jews, Muslims lived outside of Latin Christendom, Spain aside, and certainly far from the centers of the scholastic movement in France, Germany, and England; and unlike Judaism, Islam did not figure in the Bible, so there was no permanent exegetical need to think about it. For whatever reasons - whether some combination of the above or others - scholastic philosophers and theologians were remarkably uninterested in Islam. Other than those marginal figures like Raymond Lull, those in the Latin world who wrote about Islam in this period were overwhelmingly travelers and historians. ${ }^{15}$

It is striking in this connection to note that things were quite different in the Islamic world, where Christianity was often a central concern of precisely those scholars endowed with 'magnificence of learning.' The prodigious poet, jurist, and philosopher Ibn Hazm of Cordoba (d. 1064), "one of the greatest thinkers of Arabo-Muslim civilization," as the Encyclopaedia of Islam puts it, famously and relentlessly exposed the contradictions that he found in the Judeo-Christian scriptures in his exhaustive work on the great variety of Islamic sects and other religions with which he was acquainted. ${ }^{16}$ For example, in Matthew 10, he argues, we find Jesus saying that he did not come bringing peace, but the sword

13 In the Oviedo manuscript it appears alongside Riccoldo's Contra legem Saracenorum. See J. M. Mérigoux, "L'ouvrage d'un Frère Prêcheur Florentin en Orient à la Fin du XIIIe Siècle. Le Contra Legem Saracenorum de Riccoldo da Monte di Croce," Memorie domenicane 17 (1986): 35-36.

14 See Burman, Reading the Qur'an in Latin Christendom, 1140-1560, passim.

15 See, for example, $c M R$ 4, 295-306 (Jacques de Vitry), 373-80 (William of Rubruck), and 718-23 (Jean de Joinville).

16 "Ibn Ḥazm," in Encyclopaedia of Islam, 2nd ed. (Leiden: Brill Online), accessed 22 May, 2013, http://referenceworks.brillonline.com/entries/encyclopaedia-of-islam-2/ibn-hazmCOM_0325. On his life and works see, most recently, Camilla Adang, Maribel Fierro, and Sabine Schmidtke, eds., Ibn Hazm of Cordoba: The Life and Works of a Controversial 
of division, while in John 12 Jesus says that he has arrived not to judge and punish, but to save humankind. This and other obvious contrarieties, Ibn Hazm concludes, cannot be ascribed to Jesus but "to the four iniquitous men who wrote these corrupted, altered gospels."17 This eleventh-century attack on the Christian gospels runs to some eighty pages, but it pales in comparison with the book-length refutations of Christianity that Arab-Muslim scholars wrote in the age of Aquinas. For example, another Andalusī scholar known usually as the Imām al-Qurțubī, who died in the generation before Aquinas, responded to two short, Mozarabic works in defense of Christianity with a treatise, just under five hundred pages long in a modern edition, called Information about the Corruption and Delusions of the Religion of the Christians. ${ }^{18}$

Another brief Arab-Christian treatise of the late twelfth or early thirteenth century, Bishop Paul of Antioch's Letter to a Muslim Friend, together with a slightly later reworking of it, collectively provoked no less than three sustained attacks on Christianity, written between the mid-twelfth and early thirteenth centuries..$^{19}$ The last of these, The Correct Answer to those who have Changed the Religion of Christ, weighs in at more than a thousand pages in an edition from the mid-196os, and more than two thousand in a critical edition from three decades later. ${ }^{20}$ Its author, Ibn Taymiyyah (1263-1328), moreover, was a combative and profoundly influential scholar who came to be known as the Shaykh of Islam, and was as significant an intellectual in his lifetime and thereafter as Aquinas was to Christendom. Indeed, the editors of a recent collection of essays on him note: "Today, few figures from the medieval Islamic

Thinker (Leiden: E. J. Brill, 2012), whose editors characterize him as "one of the most brilliant minds produced by al-Andalus (xii)."

17 Muḥammad Ibrāhīm Nașr and 'Abd al-Raḥmān 'Umayrah, eds., Al-fișal fi al-milal wa-alahwā’ wa-l-nihal, 5 vols (Jiddah: Sharikat Maktabāt 'Ukāz, 1982). On his attack on the Bible see in particular Martin-Samuel Behloul, "The Testimony of Reason and the Historical Reality: Ibn Hazm's Refutations of Christianity," in Ibn Hazm of Cordoba, ed., Adang et al., $457-83$.

18 Aḥmad Hijāzī al-Saqqā, ed., al-I'tām bi-mā fì dīn al-nașārá min al-fasād wa-awhām wa-izhār maḥāsin dīn al-islām wa-ithbāt nubuwwat nabīnā Muhammad 'alayhi al-șalāt wa-al-salām (Cairo: Dār al-Turāth al-'Arabī, 1980). On this work see CMR 4, 391-94.

19 See CMR 4, 78-82, 583-87, 769-72.

$20 \quad$ On this work, see David Thomas, "Apologetic and Polemic in the Letter from Cyprus and Ibn Taymiyyah's Jawāb al-șahịh li-man baddala dīn al-Masīh," in Ibn Taymiyya and His Times, eds., Yossef Rapoport and Shahab Ahmed (Karachi: Oxford University Press, 2010), 247-65, and $C M R$ 4, 824-44. English readers are fortunate to have Thomas F. Michel's excellent translation and introduction: A Muslim Theologian's Response to Christianity. Ibn Taymiyya's Al-jawab al-sahih (Del Mar, New York: Caravan Books, 1984). 
period can claim such a hold on modern Islamic discourses."21 Moreover, the Correct Answer is only the longest of a number of different works that Ibn Taymiyyah wrote on Christianity. ${ }^{22}$ Even al-Ghazāli (d. 1111), 'the Proof of Islam,' whose works have shaped Islamic belief and thought more than anyone else's, felt obliged to read the Gospels carefully and write a lengthy treatise entitled The Fitting Refutation of the Divinity of Jesus through what is Evident in the Gospel. ${ }^{23}$

Furthermore, it stands to reason that Christianity was of greater concern to Muslim thinkers of 'magnificent learning' than Islam was to Latin-Christian intellectuals. Just as Christian scholars could never simply ignore Judaism because their Bible was peopled with Jews and, for the most part, written by them, Muslim scholars similarly could never pretend that Christianity was irrelevant because the Qur'an spoke so frequently about them-often negatively, but sometimes quite positively — and the Sharia required that Christians be protected within the House of Islam. As a result, there were long discussions in medieval Qur'anic commentaries, for example, about which particular Christian groups the Qur'an spoke about in the many different verses that mentioned them. ${ }^{24}$ Moreover, Christians were still a massive proportion of the population of most Islamic regimes throughout the pre-modern period. Christianity was, therefore, impossible for Muslim scholars to ignore. In later medieval northern Europe, on the other hand, Latin-Christian thinkers could still manage to behave as if Islamic religious belief hardly existed — or at least, hardly mattered. Those who read the Qur'an closely and wrote with real knowledge about Islam were overwhelmingly not the influential scholars of their age (or any age, for that matter), and what they wrote is of quite modest dimension-dozens of pages at best, not multiple hundreds.

Whether or not the Turkish conquest of Constantinople was the only reason for the remarkable change in the second half of the fifteenth century, it certainly marks it emphatically. Suddenly we find intellectuals such as Aeneus

21 Youssef Rapoport and Shahab Ahmed, "Introduction: Ibn Taymiyya and His Times," in Ibn Taymiyyah and his Times, $3^{-20}$ at 4.

22 See $C M R$ 4, 824-78.

23 See CMR 3 [Maha El Kaisy-Friemuth, "Al-Ghazālī," in Christian-Muslim Relations. A Bibliographical History, General Editor David Thomas (Leiden: Brill Online, 2013). Reference. University of Tennessee. Accessed 28 May, 2013, http://referenceworks. brillonline.com/entries/christian-muslim-relations/al-ghazali-COM_24677]. While doubts have been expressed about the attribution of this work to al-Ghazālī, recent scholarship tends to trust it and to insist that if it is not his work, then it is the work of someone in his circle.

24 See Jane Dammen McAuliffe, Qur'ānic Christians: An Analysis of Classical and Modern Exegesis (Cambridge-New York: Cambridge University Press, 1991), passim. 
Silvius Piccolomini (later Pope Pius II) and Juan de Segovia writing extensive treatises against Islam. Most notably, however, we find Cardinal Cusanus compiling his massive Cribratio Alkorani, in which he painstakingly sifted through the same Latin Qur'an (Robert of Ketton's mid-twelfth-century version) that Peter the Venerable had offered to send to a disinterested Bernard of Clairvaux three hundred years earlier, and which the leading lights of Latin-Christian thought had ignored for so long. ${ }^{25}$ Leaving aside Raymond Lull's massive and sui generis oeuvre on Islam, the Cribratio is really the first Latin-Christian work of a scale similar to Imām al-Qurțubỉs Information about the Corruption and Delusions of the Religion of the Christians or Ibn Taymiyyah's The Correct Answer to those who have Changed the Religion of Christ, and it is certainly the first work by a northern European of great significance to Latin-Christian thought that responds to Islam at real length. ${ }^{26}$ What I think is certain is that the Cribratio has a far greater claim to fulfilling Peter the Venerable's centuries-old request than anything that came before it.

That this is so tells us a great deal about the place of Islam in the intellectual culture of the high Middle Ages, where it was a pressing concern to many in this period, but not to the leading lights of scholastic thought. Moreover, it illustrates the central importance of Cardinal Cusanus in the broader history of European reflection on Islam. Hence, the essays in this volume will probe the many dimensions of Cusanus' engagement with the religion of the prophet, as well as explore its connections with broader intellectual trends in Europe. Collectively, they will assist enormously in resolving the puzzle of Peter the Venerable's three-hundred-year wait.

25 Reinhold F. Glei and Markus Köhler, eds., Pius II. Papa, Epistola ad Mahumetem: Einleitung, kritische Edition, Übersetzung (Trier: Wissenschaftlicher Verlag, 2001). Ulli Roth, ed., Johanes von Segovia, De gladio divini spiritus in corda mittendo Sarracenorum: Edition und deutsche Übersetzung mit Einleitung und Erläuterungen, 2 vols. (Wiesbaden: Harrassowitz Verlag, 2012).

26 Ludwig Hagemann, ed., Nicolai de Cusa opera omnia iussu et auctoritate Academiae litterarum heidelbergensis ad codicum fidem edita, vol 8: Cribratio alkorani (Leipzig: Meiner, 1932-). 


\section{Editors' Introduction}

This volume is the product of papers read at the 2012 conference of the American Cusanus Society and the International Seminar on Pre-Reformation Theology of Gettysburg Lutheran Seminary. The conference is held every two years at the Seminary in Gettysburg, Pennsylvania. Our 2012 theme, "ChristianMuslim Dialogue in the Late Middle Ages," hearkens back to the very first Gettysburg Conference in $1986 .{ }^{1}$ At that time, our fledgling society focused on Nicholas of Cusa's De pace fidei (On the Peace of Faith) in a new translation by $\mathrm{H}$. Lawrence Bond and with a concordance by James Biechler, which was published in 1990. ${ }^{2}$ Thus began the Society's publication program. With the 2012 conference and this book, we return once again to De pace fidei, but in new ways. Our focus is narrower and our textual base wider. Our conference theme this time was not world religions in general, but more specifically ChristianMuslim relations of the late medieval period. Our book's subtitle sharpens this theme by including the interrelated notions of polemic and dialogue, both of which played a role in medieval interreligious conversations. Finally, the essays in this volume consider not only De pace fidei, but also Cusanus's Cribratio Alkorani (Sifting the Qur'an), along with other Muslim and Christian texts, among them the Qur'an, Ibn al'Arabi's Jesus Bezel, and the writings of John of Segovia.

Why do we return to Christian-Muslim dialogue now? Two reasons come to mind. The first reflects the American Cusanus Society's own history. Of the Society's early members, only James Biechler has worked intensively on Cusanus and Islam. ${ }^{3}$ In recent years, however, a vigorous new crop of scholars has emerged and taken the stage in the Society's sessions at the International Medieval Congress in Kalamazoo, and in Thomas Izbicki's panels with the Renaissance Society of America. The scope and quality of these sessions led us to the 2012 Gettysburg conference, and their participants are well

1 See Gerald Christianson, "First Regional Conference: A Recollection," American Cusanus Society Newsletter 4/1 (March, 1987): 2-3.

2 James E. Biechler and H. Lawrence Bond, Nicholas of Cusa on Interreligious Harmony: Text, Concordance and Translation of De pace fidei (Lewiston, NY: Edwin Mellen Press, 1990).

3 See James E. Biechler, "Interreligious Dialogue," in Introducing Nicholas of Cusa: A Guide to a Renaissance Man, ed. C. M. Bellitto, T. M. Izbicki, and G. Christianson (New York: Paulist Press, 2004), 270-296. See also Biechler, "Three Manuscripts on Islam from the Library of Nicholas of Cusa," Manuscripta 27 (1983): 91-100. 
represented in this volume: Marica Costigliolo, Rita George-Tvrtković, and Joshua Hollmann. But this volume also includes essays from a wider circle of experienced scholars who discuss Muslim responses to Christianity, as well as responses to Islam by Cusanus and other medieval Christian writers.

The second reason for our theme concerns a broader history. Sometimes horrific events remind thoughtful people of the need for conversation and dialogue. In the wake of September 11, 2001, it serves us well to recall some Christian responses to the 1453 conquest of Constantinople by Mehmet II and his Ottoman forces. This event lent urgency to what Richard Southern called 'a moment of vision' when several Latin Christians saw Islam in a "larger, clearer, and more lifelike [way] than at any previous moment, or any later period for several centuries at least." ${ }^{4}$ Among these visionaries were Nicholas of Cusa and John of Segovia, who corresponded about a conference that would lead to peace via reasoned conversation rather than a new crusade. Segovia intensified his efforts on a new translation of the Qur'an as a basis for discussion, and Cusanus wrote the dialogue De pace fidei, seeking 'a single easy harmony' among religions that would bring 'a lasting peace. ${ }^{5}$ Enlightened as these efforts were, from our perspective they look conflicted, since conversion to Christianity remained a key aim for the proposed conference and translation, and Nicholas himself died while travelling to join Pope Pius II launch another crusade. For better or worse, neither the conference nor the crusade happened.

September 11 may be stimulating a new 'moment of vision' today. The attacks on the Twin Towers and Pentagon provoked a range of responses: the 'War on Terror', real wars in Afghanistan and Iraq, barrages of propaganda of every kind and from every quarter, an increase in Islamophobia, academic and policy debates about 'Islam and the West', and — most relevant for our purposes-renewed, energized dialogues between Muslims and Christians. These conversations range from local, informal meetings to academic conferences and gatherings of policy makers. At their best, they clear the air of stereotypes and simplistic notions like Samuel Huntington's 'clash of civilizations', ${ }^{6}$

4 R. W. Southern, Western Views of the Middle Ages (Cambridge: Harvard University Press, 1962), 103 .

5 Cusanus, De pace fidei, ch. 1, n. 1, in Biechler and Bond, Interreligious Harmony, 5 .

6 Following 9/11, Huntington's earlier book, The Clash of Civilizations and the Remaking of the World Order (New York: Simon \& Schuster, 1996), became the focus for intense debate. Huntington wrote: "The underlying problem for the West is not Islamic fundamentalism. It is Islam.... The problem for Islam is not the CIA or the U.s. Department of Defense. It is the West..." (217-218). For critiques, see Edward W. Said, "The Clash of Ignorance," The Nation, October 22, 2001, http://www.thenation.com/article/clash-ignorance?page=full, downloaded 8/25/2012, and Morimichi Watanabe, "Cusanus, Islam, and Religious Tolerance" in this volume. 
while sharing a simple, practical goal: to live together in peace. The point is not to gloss over differences and disagreements, but, in Anthony Appiah's phrase, 'to get used to one another' as we come to recognize both our differences and our common ground. ${ }^{7}$ This project is hardly new, as it also marked the convivencia of medieval Spain under Muslim rule, ${ }^{8}$ and - more to the point-it recalls Cusanus's dream in De pace fidei. We hope that this volume, which focuses on Nicholas's writings on Islam and explores their wider historical contexts, will contribute to lively scholarly dialogue today.

Yet we must also address another difficult question. When we first announced the conference's theme of "Christian-Muslim Dialogue in the Late Middle Ages," one colleague quipped, "Was there any?" For many, the answer is "No." The historian of Arabic philosophy, Rémi Brague, cautions against projecting our dream of interreligious dialogue and tolerance onto the Middle Ages, and writes: "In the Middle Ages, true dialogues between Islam and Christianity were extremely rare, and, if we mean by that such dialogues as we think desirable, simply nonexistent." John Tolan's book Saracens, which provides an overview of the complicated history of medieval Christian-Muslim relations, bears out Brague's observation to a certain extent. ${ }^{9}$ But while relations varied greatly across time and place, polemics do seem to have dominated, and a dialogue like De pace fidei appears "more a literary genre than a reality."10 Indeed, De pace fidei is no stenographic record of an interfaith summit meeting, but rather a dream vision, describing a conversation in a heavenly council where the Almighty God presides. But is not Nicholas's dream of peace among religions and nations more like ours than Brague allows? We may also question Brague's standards for 'true dialogue' - that is, according to our standards — and ask the question differently: what did dialogue look like in the

Kwame Anthony Appiah, Cosmopolitanism (New York: Norton, 2006), 85. See Mahmoud Ayoub, "Christian-Muslim Dialogue: Goals and Obstacles," in Ayoub, A Muslim View of Christianity: Essays on Dialogue, ed. I. A. Omar (Maryknoll, NY: Orbis Books, 2007), 64-69. There is a voluminous literature on Christian-Muslim-Jewish relations in medieval Spain. Here is just a sampling: Olivia Remie Constable, ed., Medieval Iberia: Readings from Christian, Muslim, and Jewish Sources (Philadelphia: University of Pennsylvania, 2011); Thomas E. Burman, Religious Polemic and the Intellectual History of the Mozarabs, c. 1050-1200 (Leiden: Brill, 1994); Lucy Pick, Conflict and Coexistence: Archbishop Rodrigo and the Muslims and Jews of Medieval Spain (Ann Arbor: University of Michigan Press, 2004); and María Rosa Menocal, The Ornament of the World: How Muslims, Jews, and Christians Created a Culture of Tolerance in Medieval Spain (Boston: Little, Brown, 2002).

9 John Tolan, Saracens (New York: Columbia University Press, 2002).

10 Rémi Brague, The Legend of the Middle Ages, trans. L. G. Cochrane (Chicago: University of Chicago Press, 2009), 202. 
Middle Ages? ${ }^{11}$ At the level of daily life, we can safely assume that Muslims and Christians talked to each other in areas where they lived together for centuries - the eastern Mediterranean, North Africa, Spain, Sicily, the Balkans, etc. Similarly, commerce required travel, so that Turkish merchants established their own centers in Venice, Ragusa, and elsewhere. Interestingly, in corresponding with John of Segovia, Cusanus suggests that merchants and lay people-not clerics and theologians - should participate in their proposed conference of Muslims and Christians. Missionaries also travelled, and the Dominicans Riccoldo da Montecroce and William of Tripoli not only wrote polemical works against Islam, but also praised the moral integrity of the Muslim communities where they lived. ${ }^{2}$

Sacred texts, their translations, and commentaries open other levels of engagement and dialogue. One of the authors in this volume, Asma Afsaruddin, emphasizes that the Quran "usually refers to itself as confirming prior revelations" - the Hebrew and Christian Bibles-rather than superseding them, as triumphalist commentators later claimed..$^{13}$ But even in claiming the Qur'an to be the final revelation that renders the Bible obsolete, these Muslim commentators acknowledge its biblical background. Either way, the issue concerns a complex textual history, where interpreters-depending on their points of view-often considered the Bible or the Qur'an to be riddled with distortions and corruptions. For example, as Sandra Keating discusses in this volume, Muslim critics like Ibn Ḥazm regularly identify falsifications (tahrif) in Biblical manuscripts, and Cusanus similarly blames Muhammad's Jewish

11 It is beyond the scope of this introduction to provide an overview of medieval ChristianMuslim relations, or to outline questions of genre, audience and manuscript tradition; we leave this to the articles that follow. For such an overview, see John Tolan's Saracens, or Norman Daniel's classic Islam and the West: The Making of an Image (Edinburgh: University of Edinburgh Press, 1962). For a comprehensive list of primary texts related to medieval Christian-Muslim relations, see the magisterial: David Thomas et al., eds., Christian-Muslim Relations: A Bibliographical History, 5 volumes (Leiden: Brill, 2009-2013).

12 See Rita George-Tvrtković, "After the Fall: Riccoldo da Montecroce and Nicholas of Cusa on Religious Diversity," Theological Studies 73 (2012): 641-662; George-Tvrtković, A Christian Pilgrim in Medieval Iraq: Riccoldo da Montecruce's Encounter with Islam (Turnhout: Brepols, 2012); and Thomas F. O'Meara, "The Theology and Times of William of Tripoli, O.P.: A Different View of Islam," Theological Studies 69 (2006): 80-98.

13 Asma Afsaruddin, "Finding Common Ground: 'Mutual Knowing,' Moderation and the Fostering of Religious Pluralism," in Learned Ignorance: Intellectual Humility among Jews, Christians, and Muslims, ed. James L. Heft, Reuven Firestone, and Omid Safi (Oxford: Oxford University Press, 2011), 77. See also her essay in this volume, "The Messiah 'Isa, Son of Mary: Jesus in the Islamic Tradition." 
advisors for introducing errors into the Qur'an. ${ }^{14}$ Translation and interpretation further complicate these hermeneutical issues. As Thomas Burman, the author of our preface, has documented in his earlier writings, close study and translation of the Qur'an lead to the 'slippages' that occur in Latin translations of the Qur'an:

The gradual and unaware transformation of purpose that extensive engagement with a text sometimes brings an insensible shifting of pragmatic, polemical interest in the text into a 'drive for completeness' and systematic coverage. ${ }^{15}$

Marica Costigliolo, another author in this volume, finds this slippage in Cusanus's Cribratio Alcorani, where his polemical intent led him to undertake "an out-and-out textual comparison between the Christian tradition and the Qur'anic text."16 She thus considers the Cribratio a 'dialogic work,' and describes "the medieval dialogue [as] a sort of exegetical commentary on the text."17 In this respect, dialogue becomes less a matter of face-to-face conversation than a hermeneutical affair, as polemicists, translators, and interpreters address each other through their readings of the Qur'an and Bible. Traditions of reading and interpretation thicken as Muslim and Christian commentators use and criticize their predecessors' works. In addition, theologians and mystics take these exegetical discussions in new directions, as when Ibn 'Arabi develops his novel Christology. The outcome resembles a maze of postmodern hypertexts within which medieval authors and we ourselves must find our way.

We therefore suggest that this hermeneutical view of medieval dialogue provides a useful framework for this volume of essays, which considers ChristianMuslim conversations by reading an assortment of texts, from the Qur'an to Cusanus to Ignatius of Loyola. In the process, we inevitably continue this dialogue among ourselves as we consider these texts' implications for ChristianMuslim relations today.

14 Nicholas of Cusa, "Cribratio Alkorani," in Nicolai de Cusa Opera Omnia, ed. L. Hagemann, vol. VIII (Hamburg: Meiner, 1986), n. 11.

15 Thomas Burman, Reading the Qu'rān in Latin Christendom, 1140-1560 (Philadelphia: University of Pennsylvania Press, 2007), 75 .

16 Marica Costigliolo, "Qur’anic Sources of Nicholas of Cusa," Mediaevistik 24 (2001): 237. See also Costigliolo, "Perspectives on Islam in Italy and Byzantium in the Middle Ages and Renaissance" in this volume.

17 Costigliolo, "Qur’anic Sources," 228. 
This volume is divided into three sections. Part I centers on Nicholas of Cusa's engagement with Islam, especially in the texts De pace fidei and Cribratio Alkorani. The essays place these works within Cusanus's career and trace their connections to his other writings on Islam, as well as to his wellknown treatise, De docta ignorantia. They also highlight Nicholas's Christology, Trinitarian theology, and his irenic formula: 'one religion in a variety of rites (una religio in varietate rituum).' Part II, "Historical Perspectives," considers the medieval Christian context out of which Cusanus wrote. Jesse D. Mann translates and analyzes a text by Juan de Segovia, who corresponded with Nicholas about Islam. Other essays take a wider view. Rita George-Tvrtković compares Cusanus's views of Muslim and Jewish religious practices or 'rites' with those of Alan of Lille and Riccoldo da Montecroce. Marica Costigliolo places Nicholas's work within the broad panorama of Latin and Byzantine perspectives on Islam, and Paul Richard Blum contrasts Raymond Lull's and Ignatius of Loyola's personal encounters with Muslims. By presenting a variety of medieval Muslim responses to Christianity, Part III marks an essential feature of the Gettysburg conference and this book. For if we are to take seriously dialogue and polemic between Christianity and Islam, we cannot limit ourselves to Christian views of Islam. We must consider Muslim perspectives as well. Here, Asma Afsaruddin and Robert J. Dobie discuss Muslim accounts of Jesus-'Isa ibn Maryam - from the Qur'an and the Islamic tradition up to the Sufi theologian, Ibn 'Arabi. Sandra Toenies Keating and Tamara Albertini survey critical views of Christianity and its sacred texts, and the interpretive strategies that drive these Muslim critiques.

To conclude, a collaborative book like ours incurs many debts, but here we can acknowledge only a few. Because the book stems from the 2012 Gettysburg conference, we thank the Gettysburg Lutheran Seminary for their gracious hospitality, and the Community of Christ in the City for their grant in memory of Fr. Richard John Neuhaus, whose generosity over the years as chair of the Arthur Carl Piepkorn Fund helped make these conferences possible. We thank the St. Nicholas Hospital in Kues and its librarian, Marco Broesch, for providing the perfect cover illustration for this book: the opening leaf of De pace fidei from the manuscript of Cusanus's works that he himself commissioned. We are also grateful to Christopher Bellitto for introducing this book project to Brill, and to Arjan van Dijk and Ivo Romein for skillfully guiding us through the editorial process. But most of all, we thank our authors. Not only are they colleagues, friends, and exemplary scholars, but their timely cooperation has made editing this volume a joyful task. 
PART 1

Cusanus and Islam 



\title{
Cusanus, Islam, and Religious Tolerance ${ }^{1}$
}

\author{
Morimichi Watanabe
}

Recently, it has become an urgent issue for us to consider the relationship between Christianity and Islam more seriously. This question, however, has existed since the seventh century, when Islam became a serious problem for Western Europe, resulting in numerous crusades between the twelfth and fifteenth century. As a medievalist who has for many years been studying one of the most prominent theologians, philosophers, and legalists of the fifteenth century, Nicolaus Cusanus (1401-1464), I wish to explore his ideas on religious tolerance, as expressed in his writings as well as in the activities throughout his life.

\section{Cusanus and Islam}

Cusanus must have had a great interest in Islam, even early in his career. This interest is already evident in his sermon given in Koblenz, Germany, in 1428 or 1430. In his Sermo I, the first part, De nominibus Dei, Cusanus mentions that in Turkey and among the Saracens, God's name, 'olla ubacber,' meant great and just God ("in Turkia et Saracenia 'olla ubacber,' id est 'iustus deus magnus'”). ${ }^{2}$ Also during 1433 and 1437, when he was attending the Council of Basel (14311449), Cusanus obtained the Latin translation of the Quran, and thus read and studied it, together with his close friend Juan de Segovia (c. 1400-1456), a Spaniard who is known for his keen interest in and knowledge about Islam. ${ }^{3}$ The aforementioned Latin translation of the Qur'an had been completed by an Englishman, Robert of Ketton (Robertus Ketenensis, fl. 1136-1157), ${ }^{4}$ under the

1 Editors' note: Professor Watanabe presented the first version of this article at the 2003 meeting of the Japanese Cusanus Society. In 2006 he revised and translated it into English. We thank his wife, Dr. Kiyomi Watanabe, for permitting us to publish this article.

2 Sermo I, n. 5 in Nicolai de Cusa Opera omnia XVI (Hamburg: Felix Meiner, 1970). Hereafter this edition will be cited as ' $h$ ' followed by volume number.

3 Cribratio Alkorani, Preface, n. 2; h VIII; Jasper Hopkins, trans., Nicholas of Cusa's De pace fidei and Cribratio Alkorani (Minneapolis: Arthur J. Banning Press, 1990), 75.

4 The birthplace of this mathematician and astronomer is said to be: Ketton-Kettenensis, Reading-Retinensis, Chester-Castrensis, etc. He went to Spain and studied astronomy and 
auspices of Peter the Venerable, the abbot of Cluny (1122-1156). The book is a part of the Toledo Collection (Collectio Toletana), which survives in Cusa's personal collection at the library of the St. Nicholas Hospital, established by Nicholas himself in Bernkastel-Kues, the town of his birth (Cod. Cus. 108). ${ }^{5}$

In the preface to his book Cribratio Alkorani (The Sifting of the Qur'an), Cusanus wrote the following account: while he was visiting Constantinople in 1437 he found an Arabic manuscript of the Quran which was owned by a Franciscan friar living at the Holy Cross church. Cusanus was also able to consult the same Latin translation of the Qur'an that he had previously obtained in Basel. ${ }^{6}$

The conquest of Constantinople by the Turks on May 29, 1453, must have been a shocking event for Cusanus, as for many other Europeans. ${ }^{7}$ Cusanus's famous book, De pace fidei (On the Peaceful Unity of Faith), completed in September 1453, can be considered as one of his responses to that catastrophe. As this work clearly shows, Cusanus was not only concerned with Islam, but also with Judaism, Hinduism, and other religions and nations. To discuss unity and peace among various religions, De pace fidei includes the following interlocutors: Greek, Italian, Arab, Indian, Chaldean, Jew, Scythian, Frenchman, Persian, Syrian, Spaniard, Turk, German, Tartar, Armenian, Bohemian, and Englishman. ${ }^{8}$ Cusanus included many nations and religions in the narrative's conversation, even Indians and Tartars (Mongols) from the East, though it is regrettable that he did not mention Buddhists. ${ }^{9}$

The general tone of De pace fidei is very peaceful and harmonious. It is clear that Cusanus took an attitude that sought harmony and tried to find a basic, common theme among the various world religions. Accordingly, Cusanus argued that although there are many differences in the rites (ritus) of various religions, their basic principles are "the one faith, una religio." ${ }^{10}$ Therefore, he

mathematics in Arabic in Toledo and other towns. He translated the Qur'an into Latin at the request of Peter the Venerable in 1142.

5 J. Marx. Verzeichnis der Handschriften Sammlung des Hospitals zu Kues bei Bernkastel a./Mosel (Trier: Selbstverlag des Hospitals, 1905), 106-108; James E. Biechler, "Three Manuscripts from the Library of Nicholas of Cusa," Manuscripta XXVII (July 1983): 92.

6 Cribratio Alkorani, Preface, n. 2; Hopkins, Nicholas of Cusa, 75.

7 Erich Meuthen "Der Fall von Konstantinopel und der lateinische Westen," Historische Zeitschrift 237 (1983): $1-35$.

8 For Cusanus's opinion on Tartars, see Kazuhiko Yamaki, "Shinko no Heiwa (De pace fidei)," Bunka Ronshu 23 (September, 2003): 1-21.

9 K. Yamaki, trans., Shinko no Heiwa, (De pace fidei), 582. According to Cusanus, Buddhists were "idol worshipping Indians" (Yamaki, 597-598).

10 De pace fidei, I, n. 6; Hopkins, Nicholas of Cusa, 35. 
concluded that religions must seek harmony and mutual help through discussions and reciprocal understanding, rather than choosing to compete or reject each other. Such was the interpretation of Cusanus's idea and consequent proposal: 'one religion in a variety of rites, una religio in rituum varietate.'11

The idea that many religions can co-exist - that is, the concept of religious pluralism - had been widely accepted in Europe; it was particularly popular among the scholars of the post-Enlightenment period. ${ }^{12}$ One of the best examples is seen in the book published in 1787 by Johann Salomo Semler (17251791), Des Kardinals Nikolaus von Cusa Dialogus von der Übereinstimmung oder Einheit des Glaubens. ${ }^{13}$ Growing up in pietistic surroundings as the son of a Lutheran pastor, Semler entered the University of Halle at age seventeen, where he became the disciple, the assistant, and finally the literary executor of the rationalistic Professor Sigmund Jacob Baumgarten (1706-1757). In $175^{2}$ Semler became a professor of theology in Halle. His numerous writings, said to number about two hundred and eighty-two, indicate his interest in theology, Church history, classical languages, logic, mathematics, and other areas. One of the first German theologians to apply the historical-critical method to the study of the Biblical canon and text, Semler, as 'frommer Aufklärer', became the leader of 'Neologie', the second phase of the Protestant theology of the Enlightenment (c. 1740-1780). His book on Cusanus reflects this kind of approach to theology and Church history. ${ }^{14}$

In this connection, I may be permitted to recall my own experience many years ago. In 1964, I was invited to an International Congress that was held at Bressanone (Brixen), Italy, to celebrate the passage of five hundred years since the death of Cusanus. At the Congress, I was given the chance to present a

11 Among many studies on this concept, the famous ones are: Michael Seidlmayer, "Una religio in rituum varietate: Zur Religionsauffassung des Nikolaus von Cues," Archiv für Kulturgeschichte 36 (1954): 145-207; and Bruno Decker, "Nikolaus von Kues und der Friede unter der Religionen," in Humanismus, Mystik und Kunst in der Welt des Mittelalters, ed. Josef Koch (Leiden: E. J. Brill, 1959), pp. 94-121.

12 Decker, "Nikolaus von Kues," 111-112, 118.

13 Johann Salomo Semler, Des Kardinals Nikolausvon Cusa Dialogusvon der Übereinstimmung oder Einheit des Glaubens (Leipzig: 1787).

14 On Semler's life and ideas, see Werner Raupp, "Johann Salomo Semler," BiographischBibliographisches Kirchenlexikon XIV (1998): 1444-1473; Encyclopedia Britannica, 11th ed. (1911), 631. For a helpful study of four leaders of the nineteenth-century German Awakening, see David Crowner and Gerald Christianson, ed., trans. and intro., Spirituality of the German Awakening (New York: Paulist Press, 2004). 
paper entitled "Nicholas of Cusa and the Idea of Religious Tolerance."15 The presiding officer of the meeting was Prof. Raymond Klibansky (1905-2005), one of the leading authorities in this field; I was then a young fellow who had just received a Ph.D. degree. I still remember the fright and thrill during my presentation in front of so many distinguished scholars. Though my paper was a rather immature product, I emphasized two points: 1) In order to understand Cusanus's De pace fidei, it is necessary not only to study its content but also to consider the background of the period; and 2) in support of some scholars' interpretations, I argued that Cusanus's attitude on the relationship between Christianity and other religions was not based on completely relativistic views of religious tolerance. Forty years later I am again discussing a similar subject. Hopefully I have gained more insight into the subject since then.

After writing De pace fidei in 1453, Cusanus had to face another and bigger challenge in dealing with Islam. At the request of his close friend, Pope Pius II (1458-1464), Cusanus wrote Cribratio Alkorani, The Sifting of the Koran, between 1460-1461. ${ }^{16}$ In its preface, Nicholas describes the books and manuscripts that he used to write the work. Those books are still kept in the library of the St. Nicholas Hospital, mentioned above as Cod. Cus. 107 and Cod. Cus. $108 .{ }^{17}$ The preface also reports that he had urged Dionysius the Carthusian (1402-1471) to write a book against Islam, and that Dionysius consequently wrote a voluminous work entitled Against the Infidelity of Mohammed (Contra Perfidiam Machometi $),{ }^{18}$ which was dedicated to Pope Nicholas V (1447-1455). ${ }^{19}$ Cusanus also mentions that he had consulted the following books: Against the Law of Saracens (Contra Legem Saracenorum), by the Dominican friar Ricoldus de Monte Crucis (c. 1243-1320); ${ }^{20}$ On the Basis of Faith written to Cantor of Antioch (De Rationibus Fidei ad Cantorem Antiochenum), by Thomas Aquinas; ${ }^{21}$ and

15 This paper was later published as: Morimichi Watanabe, "Nicholas of Cusa and the Idea of Tolerance," in Nicolò Cusano agli inizi del mondo moderno (Firenze: G. S. Sansoni, 1970), 409-418; and reprinted in Watanabe, Concord and Reform, ed. T. M. Izbicki and G. Christianson (Aldershot: Ashgate/Variorum, 2001), 217-226.

16 Cribratio Alkorani, h VIII, ed. Ludwig Hagemann (Hamburg: Felix Meiner, 1996).

17 Cf. Note 4.

18 Cribratio Alkorani, Prologue, n. 4.

19 Cod. Cus 107, fol. 1r-193v; Ludwig Hagemann, Christentum Contra Islam (Darmstadt: Wissenschaftliche Buchgesellschaft, 1999), 72.

20 Cod. Cus. 107, fol. 194r-232v; Hagemann, Christentum, 50, 55, 6o-61. For Ricoldus de Monte Crucis, see Ludwig Hagemann, Der Kur'an in Verständnis und Kritik bei Nikolaus von Kues: Ein Beitrag zur Erhellung islamisch-christlicher Geschichte (Frankfurt: Verlag Josef Knecht, 1976), 56-57.

21 Hagemann, Christentum, 51-54; Hagemann, Der Kur'an, 67-68. 
Against Basic Errors on Mohammed's Unfaithfulness (Contra Principales Errores Perfidi Mohameti), by Juan de Torquemada. ${ }^{22}$

There is no doubt that Cribratio Alkorani is much more critical of Islam compared to the harmonious attitude shown in De pace fidei. In the first book of Cribratio the emphasis is mostly on the oneness of God and, therefore, no strong criticism of Islam is set forth. However, in the latter part of the work, particularly in Chapter 19 of Book II, which is entitled "An Invective against the Qur'an," very severe criticisms are presented. ${ }^{23}$

In this connection I wish to cite a similar change in attitude toward Islam by Ramon Llull (1232-1316), who greatly influenced Cusanus. Llull was, in his early career, very much interested in Islam, making a great effort to study Arabic as well as the Qur'an. Llull's earlier works include his more irenic Book of the Gentile and Three Wise Men. However, in his later years Llull changed his attitude and developed a very strong criticism against Islam. This eventually led to Llull's activities that were based not on peaceful conversation and persuasion, but on more forceful and aggressive debates. ${ }^{24}$

There are many reasons why Cusanus, who at first adopted a very peaceful and cooperative attitude toward many religions, including Islam, later changed and became very critical of Islam. First, more serious and deeper studies of Islam may have brought a deeper understanding of the Qur'an and a clearer revelation of the nature of Islam, thus exposing its weaknesses and mistakes, or its anti-Christian doctrines..$^{25}$ The Qur'an denies Jesus Christ as Son of God several times. It also denies not only the death of Christ on the Cross, ${ }^{26}$ but also the Trinity, a most fundamental doctrine in Christianity. ${ }^{27}$

Second, there were changes in Cusanus's life and in his position within the Catholic Church. Since 1458 he resided in Rome, the center of the Catholic Church, and in 1459 he temporarily became a representative of Pope Pius II, who was at the Congress of Mantua (1459-1460); the holder of such a post had to defend the existing system of Christendom. The responsibilities of this position must have made Cusanus more sensitive to and critical of Islam; thus, he tried to defend Christianity against the attack on the Catholic Church and

\footnotetext{
22 Hagemann, Christentum, 72; Hagemann, Der Kur'an, 68.

23 Cribratio Alkorani, II, 19, nn. 154-158, Invectio Contra Alkoranum; Hopkins, Nicholas of Cusa, 146-149.

24 Hagemann, Christentum, 63-67.

25 For example, see the following verses of the Qur'an, Suras 5:66, 9:30-31, etc.

26 Sura $4: 157^{-158 .}$

27 Sura 4: 171 .
} 
Christian world. ${ }^{28}$ It should be remembered that Pope Pius II wrote his famous letter to the Ottoman sultan Mehmet II (1451-1481) in 1461, proudly stressing the strength of the Christian world. ${ }^{29}$

Third, Cusanus had a deep friendship with Pope Pius II, and desired to help him in his great effort to organize the crusade against the Turks, for which the pope had made a declaration at the Congress of Mantua. This is clearly shown in the beginning sentence of the Cribratio Alkorani, which Cusanus dedicated to Pope Pius II:

O, most holy Pope, accept this book composed with zealous faith by your humble servant. Accept it so that when ... you show ... that the Mohammedan sect (which has arisen from this heresy [the Nestorian heresy]) is in error and is to be repudiated, you may readily have at hand certain basic points needful to know. ${ }^{30}$

Fourth, the Latin translation of the Qur'an, which had been completed by Robert of Ketton in 1143, contained several errors, and thus Cusanus could have misunderstood parts of the Qur'an. ${ }^{31}$

\section{Cusanus and Pia interpretatio}

In Cribratio Alkorani Cusanus proposes a "generous, or sympathetic interpretation, pia interpretatio"32 of the Qur'an, hoping to apply this interpretation to understand the Muslim holy book. However, according to L. Hagemann, "it should be understood that such an interpretation of the Qur'an by Cusanus is nothing but a generous, harmonious and friendly attitude toward Islam, though standing firm at the basis of Christianity." ${ }^{33}$ As he did with his well-

\footnotetext{
28 Hagemann, Christentum, 6-63.

29 Giuseppe Toffanin, Lettera a Maometto II (Naples: Pironti, 1953); Albert R. Baca, ed., Aeneas Silvius Piccolomini: Epistola ad Mahomatem II (New York: Peter Lang, 1989).

$30 \quad$ Cribratio Alkorani, n. 1; Hopkins, Nicholas of Cusa, 75. Here Cusanus understands Islam as "Mohammad's sect." Hagemann, Christentum, 71.

31 For the faults in the Latin translation of the Koran by Robertus, see Thomas E. Berman, "Tafsir and Translation," Speculum 75/3 (July 1998): 703-732. Cf. James E. Biechler, "Nicholas of Cusa and Muhammad: A Fifteenth Century Encounter," The Downside Review 101 (January 1983): 55 .

32 Biechler, "Nicholas of Cusa and Muhammad," 55-56; Hagemann, Christentum, 69.

33 Hagemann, Christentum, 69.
} 
known revelation of the forgery of 'Emperor Constantine's donation' in $D e$ concordantia catholica (1433/34), ${ }^{34}$ Cusanus must have employed meticulous attention in studying the Qur'an, as well. His enthusiasm for a literal, interpretative, and humanistic approach is clearly seen in his Cribratio Alkorani. ${ }^{35}$

The phrase 'pia interpretatio' appears four times in Book II of Cribratio. ${ }^{36}$ Cusanus's own marginal notes, added to the Latin translation of the Qur'an that still exists in the St. Nicholas Hospital Library in Bernkastel-Kues, show that he must have written such notes three times. The first notes were probably written in 1433, at the time of the Council of Basel. The second notes were written in 1453, before the publication of his De pace fidei, and the third were in 1460-1461, during the writing of Cribratio Alkorani. ${ }^{37}$ Cusanus was almost sixty years old when he wrote the last footnotes, which was when he read the Qur'an most seriously. His notes are short, but they reveal his enthusiasm and meticulous attention to his study. ${ }^{38}$

In order to write Cribratio Alkorani, Cusanus studied the Qur'an intensely but ignored those Qur'anic verses that were problematic for Christians, such as the polygamy of Mohammed and his supposedly unethical lifestyle, as well as the erotic pleasures given at entering paradise, where one meets beautiful ladies with sparkling eyes. ${ }^{39} \mathrm{He}$ also suggested ignoring those parts that were related to the Jewish or Nestorian faiths. Cusanus recommended that, in the Qur'an, one should pay attention only to the teachings that are more agreeable to the Christian gospel and harmonious with the writings of the New and Old Testaments. In his letter to John of Segovia (1454) he wrote: "We must always strive to make that authoritative book for the Muslims applicable to us." ${ }^{\text {"0 }}$ Thus, it is easy to understand why Cusanus wrote the following in the Cribratio Alkorani:

Now, my intention is as follows: having presupposed the Gospel of Christ, to analyze the book of Muhammad and to show that even in it there are

Morimichi Watanabe, The Political Ideas of Nicholas of Cusa, with Special Reference to his De concordantia catholica (Genève: Librairie Droz, 1963), 145-156.

35 Biechler, "Three Manuscripts," 96, 100. Cf. R. W. Southern, Western Views of Islam in the Middle Ages (Cambridge, MA: Harvard University Press, 1962), 93-94.

36 Cribratio Alkorani II, 1, n. 86; II, 12, n. 119; II, 13, n. 124; and II, 19, n. 154; Hopkins, Nicholas of Cusa, 115, 129, 132, and 147; Hagemann, Christentum, 69.

37 Biechler, "Three Manuscripts," 93, 95.

38 Biechler, "Three Manuscripts," 95.

39 Suras 44:54, 52:20, 55:56, 72, and elsewhere. Cf. Biechler, "Nicholas of Cusa and Muhammad," 53, 55; Hagemann, Christentum, 61. Biechler, "Nicholas of Cusa and Muhammad," 53; Hagemann, Christentum, 69. 
contained those teachings through which the Gospel would be altogether confirmed, were it in need of confirmation, and that wherever the Koran disagrees with Christ, this disagreement has resulted from Muhammad's ignorance. ${ }^{41}$

This attitude of Cusanus in interpreting the Qur'an shows that he recognized the significance of Christianity, but also found a similar doctrine in the teachings of Islam. Accordingly, Hagemann says that Cusanus believed that he "could find even in the Qur'an, the gospel's principle."42

In 1464 Pope Pius II was at the port of Ancona in Italy. Although he had made a strong request to the kings of many countries to participate in a crusade, only a few vessels had come, and the Pope was greatly disappointed. Cusanus left Rome on July 3, traveling to Ancona to participate in the crusade for the Pope. However, he fell ill along the way and died at Todi on August 11. Three days later Pope Pius II also passed away in Ancona. I wonder what Cusanus would have done had he arrived in Ancona. Could he willingly support the crusade, though he had always believed in peace? If so, how would he have convinced himself to take such a position? Many questions remain unanswered; in history, ironic turns of events often occur.

\section{The Clash of Civilizations}

Professor Samuel P. Huntington of Harvard University published his article, "The Clash of Civilizations," in Foreign Affairs in 1993. Here, he wrote that world politics is now in a new age: it is no longer the age of ideology and economics as before, but now struggles center upon culture. Thus, world politics is governed by the clash of civilizations. The idea was further extended in his book, The Clash of Civilizations and the Remaking of World Order (1996), which evoked a great response. ${ }^{43}$

Huntington suggests that, although the famous historian Arnold Joseph Toynbee (1889-1975) proposed in A Study of History (12 volumes, 1934-61) that there were twenty-one major civilizations, at present only seven or eight among those twenty-one still exist. These are: Western, Confucian, Japanese, Islamic, Hindu, Slavic/Orthodox, Latin American, and, possibly, African civilizations.

\footnotetext{
41 Cribratio Alkorani, Prologue, n. 10; Hopkins, Nicholas of Cusa, 78-79.

42 Hagemann, Christentum, 78.

43 Samuel P. Huntington, The Clash of Civilizations and Remaking of World Order (New York: Simon \& Schuster, 1996).
} 
Whether or not such classification by Huntington is correct is not a question this essay can address. The real question for me is whether or not it is more appropriate and important to discuss present and future world politics on the basis of religion, rather than culture and civilization. This is because religion certainly lies at the base of civilization. I wonder why such an approach was not clearly taken by Huntington, though I suppose that it may be too problematic and may lead to too much struggle and fear among people. Aside from the question of whether Confucianism can be considered a religion, it is possible to divide Huntington's classification into Christian, Jewish, Islamic, and Hindu religions.

It is particularly clear that the relationship between Christianity and Islam has played an important role not only in European history, but also in present world politics.

We must remember that, throughout the medieval period and up to the present, many historical events brought about a big influence on the relationship between Christianity and Islam. One can recall some major events, such as the First Crusade beginning in 1095 and ending with the Eighth in 1291, the fall of Constantinople in 1453, the rise and fall of the Ottoman Empire (12991923), etc. It is unnecessary to point out that the current problems and unrest in the Near East are based on struggles between Christian and/or Jewish and Islamic countries. (As mentioned before, Cusanus did not have much knowledge of Buddhism, and, of course, this religion may not be classified as monotheistic. $)^{44}$ However, there is no doubt that Cusanus, as a great thinker, made a serious effort to reach a clear understanding of the relationships between the Jewish, Christian, and Islamic faiths.

Just before the terrorist attacks of September 11, 2001, Professor Bernard Lewis of Princeton University published a book entitled What Went Wrong, which criticizes Islamic countries. In the book, Lewis writes: "In the Muslim's own perception, Islam itself was indeed coterminous with civilization, and beyond its borders there were only barbarians and infidels." ${ }^{25}$ If faithful Muslims did take such a proud and arrogant attitude as Lewis suggests, it is understandable why there have been so many struggles between the Islamic, Jewish, and Christian religions. As a result, according to Hagemann, history has become "the history of aggression and suspicion." ${ }^{\text {"6 }}$

\footnotetext{
44 Cf. Note 9.

45 Bernard Lewis, What Went Wrong? The Clash Between Islam and Modernity in the Middle East (New York: Oxford University Press, 2002), 3.

46 Hagemann, Christentum, ix.
} 
Going back to Cusanus's solution toward Islam and the problems he faced, we recall that he emphasized mutual discussion without using military power. However, due to many conditions and problems in his time, it seems Cusanus eventually became inclined to support a crusade, as was already discussed. Regardless of his action (to help Pope Pius II in his crusade), though, Cusanus did not give up his peaceful and sympathetic attitude towards Islam, and tried also to interpret the Quran from the most favorable point of view. Although Cribratio Alkorani has been studied by many scholars in the past, in comparison with Cusanus's earlier books — such as De concordantia catholica (1433-34), De docta ignorantia (1440), and De conjecturis (1442) —Cribratio has received much attention only in recent years. As Volume VIII of the authoritative Heidelberg edition of Cusanus's Opera omnia, Cribratio Alkorani was published in 1986, with Hagemann as its editor. To those 'ecumenists' who were encouraged by the 'religious tolerance' expressed in Cusanus's De pace fidei, Cribratio may be disappointing. From the latter work one may get an impression that Islamic people are uneducated, ignorant, and idol worshippers - a view simply based on the old image of Arabs. The great Christian scholar on Islam, Georges C. Anawati, even said that it is better not to show Cribratio Alkorani to Muslims. ${ }^{47}$

The theology of Cusanus, however, is 'a theology that is meant to continue dialogue' (theologia sermocinalis). This means that one cannot lose hope of reaching an understanding and peace between the various religions. As mentioned before, ${ }^{48}$ in Cod. Cus. 107, which Cusanus had used for writing his Cribratio, he made a long footnote on 'the essence of love (De essentia amoris). ${ }^{49}$ There, he wrote: "Please note that love brings harmony and peace. As love is bigger, the larger concordance (harmony) is accomplished." The same discussion on the essence of love is also present in his Cribratio. ${ }^{50}$

47 Georges C. Anawati, "Nicolas de Cues et le problème de l'Islam," in Nicolò Cusano agli del mondo moderno (Firenze: Sansoni, 1970), 141-175, 179.

48 Cf. Note 4.

49 Biechler, "Three Manuscripts," 97.

$50 \quad$ "Nota amor unit. Et quanto maior et perfectior quanto magis unit," in Adnotatio de essentia amoris (Cod. Cus. 107, fol. 21), cited in Biechler, "Three Manuscripts," 100. In Cusanus's Cribratio Alkorani (II, n. 104), the following description is present: "Quoniam autem amor unit, amor perfectissimus, qui maior esse nequit neque minor, cum sit substantialis, maxime unit. Video igtur in essentia ipsius amoris unientis unitatem. Quomodo enim esset unus uniens amor sine unitate?" 


\section{Conclusion}

Presently there are about 1.6 billion Muslims in the world. They are not only in the Near East, but also in South and Southeast Asia, Europe, Africa, and the Americas. Among the forty-four countries in which the majority of the population is Muslim, there are great differences regarding their political stand on Islam. Some countries officially declare themselves to be Islamic countries, such as Afghanistan, Iran, Pakistan, and Saudi Arabia. In others, Islam is described as a 'national religion,' for example in Algeria, Bangladesh, Egypt, Iraq, and Malaysia. Others, moreover, have a constitution that does not mention Islam, such as Albania, Lebanon, Syria, Indonesia, and Sudan. Finally, some countries claim to be 'secular states,' such as Mali, Nigeria, Senegal, and Turkey.

In Cusanus's period, as in the present age (though problems differ), the clash between Christian countries in Western Europe and Islamic countries in the Middle East was a great concern. However, there are others who argue that present-day struggles may not be those between Christian and Islamic countries. In a book called No god but God, a young Iranian scholar, Reza Aslan, claims that in the future, the problem of the world will not be a struggle between Western European and Islamic countries. Rather, he claims, a more important problem is the intolerance and continuous fighting between Islamic countries and their people. ${ }^{51}$

Under such a state of the world as it is today, it may be argued that a religious concordance (harmony) based on 'discussion' and 'unity based on love' is ineffective and impossible. Even Cusanus appeared to have lost his confidence in this idea, due to the many hindrances he faced during his lifetime. On the other hand, when one takes a long view of human history, one can say that the very approach taken by Cusanus is the most hopeful and the best approach to solving important problems for mankind. As stated in the Bible: "Love is patient" (I Corinthians 13:4). 


\title{
A Critical Survey of Cusanus's Writings on Islam
}

\author{
Walter Andreas Euler
}

Cusanus authored three writings mainly dealing with Islam: De pace fidei, dating from September 1453, the letter addressed to John of Segovia from December 29, 1454, and Cribratio Alkorani, 1460/61. All three of these writings date from the second period of his career, after he had been appointed cardinal and bishop.

Yet Nicholas of Cusa had shown interest in Islam long before that. In his first preface to Cribratio Alkorani, Nicholas invokes his earlier endeavors to gain an understanding of Islam, referring to the Council of Basel, where he had been active from 1432 to 1437, and his journey to Constantinople in 1437. He claims to have acquired the Latin translation of the Qur'an by Robert of Ketton in Basel, and to have gone to Constantinople to search for further copies of the Qur'an. He stresses that Franciscan friars showed him an Arabic Qur'an there. ${ }^{1}$ Hence, if we want to believe him - and there is no reason to do otherwiseNicholas had already been studying the Qur'an for 17-20 years by the time he wrote De pace fidei. "I have always sought, with all that is in my power, to

1 Prol. I, Opera omnia Nicolai de Cusa (= h) VIII, n. 2: "As best I could, I made a careful attempt to understand the book-of-law of the Arabs- [a book] which I obtained at Basel in the translation commissioned for us by Peter, Abbot of Cluny. [I obtained it] together with a debate among those noble Arabs, [wherein] one of them, a follower of Muhammad, attempted to win over another of them-who, being eminent among the Arabs and quite learned, showed that the Christian faith, which he zealously observed, ought rather to be accepted. There were also [contained therein] certain other works on the origins of Muhammad, his twelve successors in the kingdom, and on his Doctrinae ad centum questiones. I left the book with Master John of Segovia and journeyed to Constantinople, where among the Minorites who were living at [the Church of] the Holy Cross, I found the Koran in Arabic. These brothers, as best they knew how, explained it to me in regard to certain of its points. But in Pera, at the Convent of St. Dominicus, [I found a copy of the Koran that] was translated in the [same] manner as [the one] I had left behind in Basel. I inquired whether any of the Greeks had written against these foolish errors. And I learned only that John of Damascus, who lived a little after the beginning of that sect, had written the very few things which were on hand there." Translated in Jasper Hopkins, Nicholas of Cusa's De pace fidei and Cribratio Alkorani: Translation and Analysis (Minneapolis: Arthur J. Banning Press, 1990), 75. Hereafter cited as Hopkins, Cusa's De pace fidei and Cribratio. 
understand the book of the law of the Arabs (= Qur'an)," says Cusanus in the opening pages of his Cribratio. ${ }^{2}$

Furthermore, alongside his Latin version of the Qur'an, translated by Robert of Ketton by order of Petrus Venerabilis in 1143 (Cod. Cus. 108 in the library of the St. Nicholas Hospital in Bernkastel-Kues), Cusanus might have also been in the possession of the Arabic original. The St. Nicholas Hospital disposed of an Arabic Quran that was sold in $1823 / 24 \cdot^{3}$

The American scholar James E. Biechler has written a remarkable essay entitled "Three Manuscripts on Islam from the library of Nicholas of Cusa," analyzing in detail the marginal notes in the Latin Quran of Nicholas of Cusa. Judging from the changes in his writing, Biechler comes to the conclusion that Cusanus must have studied the Qur'an thoroughly at least three times in his life: at the time of the Council of Basel in the first half of the 1430s, at the time of the composition of De pace fidei, and finally, when he was writing Cribratio Alkorani.

\section{De pace fidei: An Inclusive Approach to Islam}

Let us first take a look at De pace fidei. Nicholas's well-known plea, expressed in the introduction, sounds peculiar, a little bit wan and feeble against the tragic historical background of the conquest of Constantinople by the Turks. He writes: May God stop the horribly widespread persecution caused by religious differences, "ob diversum ritum religionum." ${ }^{5}$ One would normally expect a cardinal and bishop of the fifteenth century to explicitly name the responsible people and to formulate his plea in a correspondingly glaring way, for example:

May God stop the Muslim Turks and punish them with all his might for their crimes against the poor Byzantine Christians, although they themselves are more or less to blame for their fate. Therefore, they deserve a certain kind of chastisement because they have disgracefully broken off

2 Hopkins, Cusa's De pace fidei and Cribratio, 75.

3 See the discussion by Hermann J. Hallauer concerning the paper of Anton Schall: "Die Sichtung des Christlichen im Koran," Mitteilungen und Forschungsbeiträge der CusanusGesellschaft 9 (1971): 89 .

4 This article was published in the periodical Manuscripta 27 (1983): 91-100.

5 De pace fidei, ch. 1, h VII, 3, lines 3-8: "Fuit ex hiis, quae apud Constantinopolim proxime saevissime acta per Turkorum regem divulgabantur, quidam vir zelo Dei accensus, qui loca illarum regionum aliquando viderat, ut pluribus gemitibus oraret omnium creatorem quod persecutionem, quae ob diversum ritum religionum plus solito saevit, sua pietate moderaretur." 
the union with the Latins, but their guilt is by far less severe than that of the Turks.

All this is analogously expressed in the sermon that the cardinal and princebishop Nicholas of Cusa delivered in Neustift, near Brixen, on August 24, 1456. It is sermon CCXL. ${ }^{6}$ The occasion was a procession to celebrate the victory over the Turks near Belgrade on July 22, 1456. In that sermon, Cusanus calls the Turks a scourge, a flagellum - an image also found in his letter to John of Segovia from December 29, $1454^{7}$ — which is meant to wake up the somnolent Christians. And he adds:

God will prove to be the loyal guardian of us Christians if we, filled with faith, seek refuge in him, knowing that we will undoubtedly be saved ${ }^{8}$ if we trust in his protection, willingly and with all our heart. ${ }^{9}$

The reason Nicholas does not express any anti-Islamic ideas or announce an intellectual crusade plan in the introduction of De pace fidei, contrary to Sermon CCXL, is very simple. Islam, the religion of those who have invaded and conquered Constantinople, was meant to be integrated into the concordance of religions, which the cardinal became aware of after long days of contemplation. Thus, his argumentation in the introduction is already quite revealing. It shows 'in nuce' the theological conception concerning Islam that would develop throughout the work. All further explanations confirm that first impression. It becomes clear that Cusanus does not consider Islam to be hopelessly corrupted, anti-Christian, and demoniacal, but instead finds that it contains a true and sane core that needs to be carefully exposed first. His

6 Sermo CCXL, h XIX, n. 3-4.

7 Epistola ad Ioannem de Segobia, h VII, 100, lines 16-25: "Nam pluries tepiditate Ecclesiam subintrante excitata sunt flagella. Venerunt Romam aliquando Sarraceni et Ecclesiam sancti Petri depraederunt; excitata dormiens Ecclesia ad Dominum habuit refugium. Odit Deus tepiditatem, quia Deus zelotes. Unde, si occasiones tollerentur quare contra nos sed pro nostra salute et decore Ecclesiae Christus ista permittit, esset infallibile remedium. Ego firmissime credo non ad mortem sed vitam, non ad suppressionem sed exaltationem fidei persecutionem permitti. Ecclesia hoc proprium habet quod sub persecutione splendescit."

8 Here, Nicholas alludes not only to the eternal salvation, but also to the rescue from the threat of the Turks.

9 Sermo CCXL, h XIX, n. 5: "Haec est dies boni nuntii, in quo recepimus plures litteras huius miraculosae victoriae. Quapropter convenimus, ut laudemus Deum, qui mirabili ordine memoriam crucis renovavit, agente hoc per flagellum, quo somnolenti excitaremur ac quod invocemus eum, qui ostendit se pium protectorem, quando tota fide ad ipsum recurrimus, scientes quia indubie salvi erimus, si ex toto corde nos suae tuitione commendaverimus." 
program could be described as 'inclusion instead of exclusion'-inclusion and pro-Christian interpretation instead of exclusion and condemnation. Nicholas of Cusa consistently pursues this approach in his writing about peace in faith. Therefore, throughout his work there is not a single sentence, not a single thought condemning Islam as a fundamentally anti-Christian religious system.

How does this inclusion of Islam into the concept of De pace fidei work in detail? Cusanus simply calls the Muslims 'Arabs' —in Latin, 'arabes.' Every time that key term occurs, Nicholas invokes genuine Islamic concepts, which he seeks to link with his Christian views, the foundation of 'una religio,' the only true religion. The substance of the topics he thereby invokes can also be found in his letter to John of Segovia from December 29, $1454 \cdot{ }^{10}$ Moreover, Cusanus' argumentation is maieutic and manuductory. Maieutics is the art of midwifery attributed to Socrates in Plato's dialogues, allowing his interlocutors to gain insight into the philosophy step by step. 'Manuductio', hand guidance, is a term used by Nicholas of Cusa in his Cribratio Alkorani. ${ }^{11}$ It implies that all non-Christians, Muslims in particular, should be taken by the hand to introduce them to the Christian faith.

In chapter IX of De pace fidei, Cusanus points out that fertility is a part of God's nature. ${ }^{12} \mathrm{He}$ explains that perfection and divinity do not remain isolated; they are not sterile but procreate, because God-equally in accordance with the opinions expressed in the Quran ${ }^{13}$ — is spirit, rationality, and will. That is love in the Christian understanding. God as a spirit is aware of himself and therefore actively conceives the concept, the word of himself. The connection of both begets the will that originates from self-awareness.

According to Nicholas of Cusa, this insight is adequately represented by the Christian doctrine of the holy trinity, which in itself preserves the principle of divine unity. He is convinced that the criticism of the dogma of trinity expressed by Jews and Muslims is nothing but a misunderstanding, where the concept of the divine trinity is misinterpreted to be a tritheism, a belief in three Gods, and hence a variation of polytheism. In reality, however, Christians, Jews, and Muslims agree in this point, as all of them value the one and only true God as constructive force. Consequently, the quarrel is superfluous and senseless,

10 Cf. h VII, 97, lines 22-100, line 10.

11 The term 'manuductio' can be found in the second book of Cribratio Alkorani in the headings of chapters $5^{-7}$ and 10, which treat different aspects of the theology of the holy trinity; cf. h VIII, n. 99: "Manuductio ex his quae in mundo sunt, ut videatur deus trinus"; n. 101: "Manuductio de intellectuali trinitate ad divinam"; n. 103: "Manuductio eiusdem per amorem"; n. 111: "Iterum ex tribus personis manuductio."

12 Cf. h VII, 26, lines 11-28, line 4.

13 Cusanus refers to Sura 4:171, among others. 
caused by terms that generate different meanings. Furthermore, technically speaking Jews as well as Muslims do already believe in the holy trinity without being aware of it.

Concerning the hypostatic union of God and man in the person of Christ, Nicholas of Cusa not only aims at elucidating misunderstandings as to the use of the term, as he did with the concept of the holy trinity. Rather, he tries to dig deeper, in order to find a Christian foundation in the Qur'an. ${ }^{14}$ This 'crypto-Christian' factor is constituted by appreciative statements the Qur'an makes about Jesus the Islamic prophet, as found in Cusanus's Latin translation of the Qur'an. Such statements include: he was born by the Virgin Mary (Sura 3:47 and 19:20); he could work marvellous miracles, for instance raising the dead and making birds out of clay (Sura 3:49 and 5:110); he was the Messiah, the word and the spirit of God (Sura 4:171, among others); and finally, he was the face of all peoples and the highest being in the world. ${ }^{15}$ With exception of the last two notions, Jesus as 'the face of all peoples' and the highest being in the world, which were mistranslations in the Latin version of the Qur'an used by Cusanus, ${ }^{16}$ all other statements are authentic. Yet, though they can indeed be found in the Quran, they cannot always be interpreted from a Christian point of view. ${ }^{17}$

Nicholas of Cusa considers these statements about Jesus as maximal statements, setting the Nazarene apart from all other humans. Cusanus extensively develops this approach in his oeuvre De docta ignorantia (1440). In the first three chapters of the third book, he speculatively develops the idea that the highest individual of a species necessarily exceeds the limitations of the species. Applied to the human being as the highest of creatures, this means that the highest human is more than a mere human-he is God. Already in De docta ignorantia this consideration serves to explain and highlight the hypostatic union in Christ, without referring to the Holy Scripture. ${ }^{18}$ He then transfers this to the dialogue with Islam in De pace fidei as follows: if the Qur'an uses 'maximal' statements about Jesus of Nazareth, these statements imply that Jesus was more than a saint, more than an exceptionally gifted man through the grace of God, and that he must therefore be intimately joined to the divine nature. Cusanus frequently illustrates this point with the image of human nature as

\footnotetext{
14 Cf. h VII, 37, lines 9-39, line 15.

15 Cf. ch. 13 of De pace fidei, h VII, 40, lines 15-16: "facies omnium gentium et altissimus."

16 Cf. Adnotatio 24: h VII, 80.

17 Cf. inter alia, Claus Schedl, Muhammad und Jesus. Die christologisch relevanten Texte des Korans (Vienna: Herder, 1978). 
iron being pulled up by the divine magnet. Hence, in Christian terms, Jesus can be considered the son of God.

The cardinal does not say that the Qur'an teaches the hypostatic union in the person of Christ, but that the Muslims are 'facilius,' or more easily converted to the Christian faith, because the Qur'an gives clear hints that have just been neglected by the Muslims thus far. Nicholas of Cusa, as Christian interpreter of the Qur'an, discloses the hermeneutical key to the decryption of the Quran, without forgetting the Muslims' fear that the notion of Christ being the son of God may threaten the divine unity.

Chapter XIV of De pace fidei treats the death of Christ on the cross. ${ }^{19}$ From his Latin translation of the Qur'an, Cusanus was well aware that it categorically denies the crucifixion of Christ (Sura 4:157), though he realized the denial is meant to do Jesus honor ('ad reverentiam'). This aspect is of crucial importance for his argumentation. Cusanus ardently seeks to show that the 'mors turpissima crucis' (the ignominious death on the cross) only harmed Christ's honor at a first glance because the Muslims believe that such a death is not worthy of a true prophet. In fact, this makes it evidently clear that Jesus was only bound to God in truth and allegiance, and therefore deserves to be honored as the highest of all men. ${ }^{20}$ Furthermore, this shows that by taking a closer look at the 'gloria crucis,' or the glory of the cross, Muslims will come to acknowledge and respect it too. Cusanus's thoughts on the subject can be summarised as follows: the Muslims are doubtlessly wrong in denying the death of Jesus on the cross, but - and here the notion of inclusion becomes obvious- they are wrong because of good motives, because they want to pay honor to Jesus of Nazareth. Thus, Nicholas believes that their mistake can be reversed.

In sermon CCXL, Nicholas of Cusa identifies the vision of paradise in the Qur'an as the element of complete reversal of the message of the Gospel, done by the devil—with Mohammed working as his tool—-to seduce primitive, animalistic humans. ${ }^{21}$ Thus, the sermon claims that the vision of paradise in the Quran proves two things: it exposes the hand of the devil, as well as the intellectual inferiority of the Muslims. In chapter XV of De pace fidei, however, Cusanus introduces Mohammed as an intelligent pedagogue of the people, who succeeds in dissuading his addressees from polytheism

19 Cf. h VII, 44, lines 4-46, line 7.

20 Cf. Walter Andreas Euler, "Does Nicholas Cusanus Have a Theology of the Cross?," The Journal of Religion 80 (2000): 405-420; Euler, "Oboedire est vivere: Obedience and Freedom According to the Brixen Sermons of Nicholas of Cusa," in Nicholas of Cusa on the Self and Self-Consciousness, ed. Walter Andreas Euler, Ylva Gustafsson and Iris Wikström (ÅboTurku: Åbo Akademi University Press, 2010), 25-38. 
by evoking a land of milk and honey in his vision of paradise. ${ }^{22}$ Hence, Cusanus manages an inclusion of Islam by implying - similar to the Islamic philosopher Avicenna — that the Qur'an says something different from what it explicitly states.

\section{Cusanus and Segovia: Questioning Inclusion}

I have tried to characterize the theological approach of Nicholas of Cusa in De pace fidei regarding Islam by highlighting the notion of inclusion. This notion, however, leads to many questions. It can be seen as a legitimate inclusion of Islam or a sort of integration, but it can also be perceived as a problematic interpretation inspired by specifically Christian values that are alien, sometimes even contrary, to those of Islam.

After a while, Cusanus himself realised that his pro-Christian, inclusive interpretation entangles Islam in a certain one-sided interpretation. However, it is unknown as to when he came to this awareness. I suspect that he was still absolutely convinced that the Quran could be interpreted in a cryptoChristian way at the time he was writing De pace fidei. Nonetheless, it becomes obvious from an interesting remark in his letter to John of Segovia from December 29, 1454, that he had experienced a change of mind in the fifteen months that lay between De pace fidei and that letter.

The critical attitude of John of Segovia concerning Islam, expressed in his letter to Cusanus on December 2, 1454, might be a reason for this change. Concerning the content, Cusanus's argumentation in the letter to John of Segovia is still absolutely in line with the ideas of De pace fidei. Not without reason does Nicholas of Cusa point to that work, stating that he would send the book to the Spanish scholar once a copy became available. ${ }^{23}$ Yet, the following statement can be found after some considerations concerning the Islamic vision of paradise:

It seems as if we are obliged to keep trying to interpret that book [the Quran], so important to them, as being commissioned for our sake. For we find things in it that are useful to us; and we will interpret all the others which are contrary through the first ones. ${ }^{24}$

\footnotetext{
22 Cf. h VII, 47, lines 5-5o, line 2.

23 Cf. Epistola, h VII, 97, lines 2-4.

24 Epistola, h VII, 99, lines 22-25: "Unde videtur quod semper ad hoc conandum sit quod liber iste, qui apud eos est in auctoritate, pro nobis allegetur. Nam reperimus in eo talia quae serviunt nobis; et alia quae contrariantur, glosabimus per illa."
} 
This statement is the first literary proof that Cusanus had become aware of the Qur'an's ambivalence concerning the Christian faith. Nevertheless, he remains convinced that the pro-Christian essence of the Quran is far more substantial than the conflicting elements, and that a corresponding interpretation of Islam is therefore hermeneutically valid.

\section{Cribratio Alkorani and the Ambivalence of Islam}

Much happened during the years between the letter to John of Segovia and the composition of Cribratio Alkorani. According to Sermo CCXL, the victory over the Turks near Belgrade in the summer of 1456 seems to have raised Cusanus's hope that the expansion of Islam might be stopped and that, with God's help, everything would turn out fine for Christendom. That short moment of euphoria, however, did not last long. The sermon makes clear that Nicholas of Cusa supported the military resistance to the expansion of the Turks. He considered it as a legitimate resistance and not as an aggression, contradictory to Christ's commandment, as he points out in his letter to John of Segovia. ${ }^{25}$

Cribratio Alkorani, an utterly complex and manifold opus, is one of the most important works of Nicholas of Cusa in the last years of his life. Contrary to De pace fidei, Cribratio Alkorani does not show a clear goal in its discussion with Islam. Although the inclusive, pro-Christian interpretation of Islam is extensively represented, it is consistently thwarted by anti-Christian interpretations. Accordingly, Cusanus argues that due to 'pia interpretatione' (or pious, Christian interpretations), the Qur'an could be considered as a 'secret Gospel, ${ }^{26}$ yet it is the product of a debauchee who cared only for glory, might, and wealth. Following the older Christian apologetic, Cusanus claims that Mohammed died as a heretical Christian, ${ }^{27}$ and stresses that Mohammed's knowledge of

25 Epistola, h VII, 97, lines 5-11: "Assentio igitur rationibus vestris fundatissimis tam in iure divino quam humano; quia si iuxta doctrinam Christi processerimus, non errabimus, sed spiritus eius loquetur in nobis, cui non poterunt omnes adversarii Christi resistere; sed si invasionis gladio aggressionem eligerimus, formidare habemus ne gladio pugnantes gladio pereamus. Unde sola defensio sine periculo est Christiano."

26 Cusanus uses the phrase 'pia interpretatio' only in the second book of Cribratio Alkorani: II, 1 (h VIII, n. 86, lines 4-6); II, 12 (h VIII, n. 119, lines 1-2); II, 13 (h VIII, n. 124, lines 3-4); II, 19 (h VIII, n. 154, lines 8-9); cf. Tom Kerger, "Die cusanische Sichtung des Korans," in Cusanus und der Islam, ed. Walter Andreas Euler and Tom Kerger (Trier: Paulinus, 2010), 95-102.

27 Cf. Prol. II, h VIII, n. 11: "That noble Arab Christian whom I previously mentioned, reports the following: Sergius, a monk evicted from his monastery, journeyed to Mecca. There he found two groups of people, [viz.,] idolaters and Jews; and there he preached the 
the truth was contaminated by ignorance ('ignorantia') and perverse intentions ('perversitas intentionis'). ${ }^{28}$ Moreover, he contends that 'tres astutissimi Judaei' (three extremely sly Jews) had added anti-Christian amendments to the Qur'an, ${ }^{29}$ resulting in an even further alienation from Christianity.

Thus, in Cribratio Alkorani Cusanus considers the holy book of the Muslims to be a book containing contradictory tendencies with regard to its content, as well as a 'confusissimus liber' concerning its form. He regards the Qur'an as being a highly abstruse creation because every single chapter has to be analyzed separately, as the different Suras were not coherently connected with

Christian faith as Nestorius held it, [doing so] in order to regain favor with his [monastic] brothers, [who were also] of the sect of Nestorius. And he succeeded in converting all the idolaters to his own faith. Among these was Muhammad, who, having been converted from idolatry, died a Nestorian Christian. But three very clever Jews attached themselves to Muhammad in order to turn him aside, lest he become perfect; and they induced him to various evils. But after Muhammad's death, when all [the idolaters] returned to their own [respective] sect, these [three] Jews approached Alis—son of Abitalip—to whom Muhammad had sent his collection [of precepts], and persuaded him to elevate himself unto a prophet, even as Muhammad too [had elevated himself]. And with regard to Muhammad's book they added and deleted what they wanted to." Hopkins, Cusa's De pace fidei and Cribratio, 79.

28 Prol. I, h VIII, n. 9-10: "But Jesus, the son of the Virgin Mary and the Christ who was foretold by Moses and the Prophets to be coming, did come and did reveal most perfectly-according to the testimony even of Muhammad - the oft-mentioned way, for He was ignorant of nothing. Therefore, it is certain that anyone who follows Christ and His way will attain unto an understanding of the desired Good. Hence, if Muhammad in any respect disagrees with Christ, then it follows either that he does so out of ignorance, because he did not know Christ and did not understand Him, or that there is perverse intent, because he did not intend to lead men to that goal-of-rest to which Christ showed the way but rather sought his own glory under the guise of that goal. A comparison of the law of Christ with the law of Muhammad will teach [us] that both of these [alternatives] must be believed to be true. I believe that the following must be maintained: viz., that ignorance was the cause of [Muhammad's] error and malevolence. For no one who is acquainted with Christ disagrees with Him or detracts from Him. Now, my intention is as follows: having presupposed the Gospel of Christ, to analyze the book of Muhammad and to show that even in it there are contained those [teachings] through which the Gospel would be altogether confirmed, were it in need of confirmation, and that wherever [the Koran] disagrees [with Christ], this [disagreement] has resulted from Muhammad's ignorance and, following [thereupon], from his perverse intent. For whereas Christ sought not His own glory but the glory of God the Father and the salvation of men, Muhammad sought not the glory of God and the salvation of men but rather his own glory." Hopkins, Cusa's De pace fidei and Cribratio, 78-79.

29 Cf. Prol. II, h VIII, n. 11 (see note 27). 
each other. Nicholas of Cusa says forthrightly at the end of his second preface that he did not succeed in discerning a clear order in the Qur'an, and that was why his interpretations of the text were also rather confused..$^{30}$

With respect to the evaluation of Islam, Cribratio Alkorani ends with an odd result, which can be paraphrased as follows: the Qur'an exhibits 'inclusion and exclusion,' with pro- and anti-Christian assessments simultaneously and in equal measure. This result has led many scholars to ignore the Cribratio, and on the whole, the work does not offer a satisfactory solution for dialogue with Islam in religious and political terms. It is therefore not surprising that Pope Pius II hardly referred to the work of his cardinal when he was writing his politically motivated letter to the Turkish Sultan Mehmed II.

Yet, from the perspective of Christian theology, Cribratio clearly shows a deepened awareness of an underlying problem. The main difficulty for any Christian interpreter is the ambivalence of Islam, which displays both pro- and anti-Christian sides at the same time, as it is grounded in biblical transmissions on the one hand, but on the other hand categorically rejects the most important elements of the Christian faith: the notions of incarnation and divine trinity.

In this respect, an interesting development can be witnessed in Cusanus's writings. He ignores the anti-Christian side of Islam in De pace fidei, and presents it instead as a misunderstanding. Then, in his letter to John of Segovia, he implies that he is aware of the ambivalence (visible in his remark about the hermeneutic of the Quran), and finally he discusses it extensively in Cribratio Alkorani. It is clear that the uniformity of his interpretation of Islam and the Qur'an suffers from this very ambivalence. However, according to Cusanus's insight, the Janus face of Islam no longer allows for a uniform interpretation from a Christian point of view.

30 h VIII, n. 16. 


\title{
Una Religio in Rituum Varietate: Religious Pluralism, the Qur'an, and Nicholas of Cusa
}

\author{
Pim Valkenberg
}

This essay will focus on the possible origins of just five words. These words, however, might have been the most famous words that Nicholas of Cusa ever wrote during his long career: 'una religio in rituum varietate.' In the history of the interpretation of these words, much effort has been made to explain them by connecting them to Western philosophical or Christian theological concepts. Yet efforts to elucidate the idea of 'one religion in a variety of rites' by Nicholas of Cusa's own metaphysics have not been successful, as Thomas McTighe has shown. ${ }^{1}$ This essay will therefore interpret Nicholas of Cusa's famous words by taking seriously the historical context in which Cusanus wrote them, namely, Christianity's encounter with Islam. Consequently, the bulk of this chapter will retrace the historical sources of the words 'one religion in a variety of rites' in the Qur'an, as well as its subsequent interpretation by Muslim scholars.

Because this new approach, centered on the Islamic sources of Nicholas's famous formula, is not unrelated to contemporary debates about his role in the encounter between Christianity and Islam, it may be good to start with a few remarks about Nicholas of Cusa's role in the contemporary Christian theology of religions. In his recent book Allah: A Christian Response, Miroslav Volf uses Nicholas of Cusa as a model of a positive approach to Islam. ${ }^{2}$ He points out that Nicholas was one of the few Christian theologians who preferred to react to the Fall of Constantinople in 1453 with words rather than weapons. Exchanging letters with his friend John of Segovia, Nicholas developed the idea of organizing a sort of interfaith conference, and his work De pace fidei ('On the Peace of Faith'), written almost immediately after the conquest of Constantinople, may be seen as a blueprint for such a conference. Even though Volf is careful not to take Nicholas of Cusa out of his historical context, it is easy to see how the words 'one religion in a variety of rites' tend to be explained as a

1 See Thomas McTighe, "Nicholas of Cusa's Unity-Metaphysics and the Formula Religio Una in Rituum Varietate," in Nicholas of Cusa in Search of God and Wisdom, ed. Gerald Christianson and Thomas M. Izbicki (Leiden: Brill, 1991), 161-72.

2 See Miroslav Volf, Allah: A Christian Response (New York: HarperOne, 2011), chapter two, "A Catholic Cardinal and the One God of All," 40-59. 
foreshadowing of the pluralist approach in the present-day Christian theology of religions, according to which the different religious traditions are limited expressions of one universal faith. ${ }^{3}$ Associating Nicholas with a contemporary form of religious pluralism that is most famously represented by John Hick or Wilfred Cantwell Smith also explains why theologians who are critical of such a pluralist approach also find Cusanus's words quite ambiguous. ${ }^{4}$ Both proponents and critics of Nicholas of Cusa in the theology of religions, however, agree that the idea of 'one religion in a variety of rites' can easily be interpreted in a pluralistic way. Yet research into the sources of these words will show that they convey a different form of pluralism. They go back to an annotation that Nicholas made in his personal copy of the so-called Toledan Collection, containing Latin translations of the Qur'an and a number of other Islamic writings. His annotation, fides una—ritus diversus ('one faith—different rites'), indeed reflects a specific Islamic — or rather, Qur'anic - way of looking at religious plurality. This chapter will explain the connection between Nicholas of Cusa and an Islamic view of religious pluralism in two parts. The first part considers the two works related to Islam in which Nicholas of Cusa writes about this idea of 'one religion in a variety of rites,' and the second part is concerned with his sources in the Qur'an and the history of its interpretation in the Islamic world as it came to be known in the Latin West.

\section{Nicholas of Cusa and the Fall of Constantinople}

Nicholas of Cusa (1401-1464) served the Church as a diplomat and Cardinal, and was involved in attempts to reunite the Western (Latin) and the Eastern (Greek) Church. In order to facilitate the negotiations for reunification, Nicholas visited Constantinople sixteen years prior to its conquest by the Ottoman Sultan Mehmet II in 1453. The knowledge of Islam that he gained during his stay in Constantinople, and more specifically the Latin translations that he gathered during his travels, would help him later to express his theological reflections on the Fall of Constantinople.

The first reflection, De pace fidei, written shortly after the fall, contained a fervent plea for peace between religions. In this fictitious dialogue between

3 I have recently explored this aspect further in my article "One Faith-Different Rites: Nicholas of Cusa's New Awareness of Religious Pluralism," in Understanding Religious Pluralism: Perspectives from Religious Studies and Theology, ed. Peter C. Phan and Jonathan Ray (Eugene, OR: Wipf \& Stock, to be published in 2014).

4 See Karl J. Becker and Ilaria Morali, eds., Catholic Engagement with World Religions: A Comprehensive Study (Maryknoll, N.Y.: Orbis Books, 2010). 
representatives of many religions and cultures, Nicholas tests the possibility for a peaceful agreement. He introduces the notion of a utopian or eschatological ideal: how would the world be if all humans could know their Creator in one faith? What if they could recognize their differences as grounded in the same divine law or religion? Cusanus's literary fiction takes the form of a council, with which he was familiar as he had been present at the Council of Basel (1431). Yet Cusanus's fictitious meeting is not limited to Christians; its modern equivalent would be the League of Nations or the United Nations, with a large number of representatives of different nations. In religious terms, one could even think of the World Parliament of Religions in an eschatological setting, presided by the Word, by Christ himself. Cusanus introduces his fiction as follows:

After the brutal deeds recently committed by the Turkish ruler at Constantinople were reported to a certain man, who had once seen the sites of those regions, he was inflamed by a zeal for God; with many sighs he implored the Creator of all things that in his mercy he restrain the persecution, raging more than ever because of different religious rites. ${ }^{5}$

This man, in whom we might well recognize Cusanus himself, seems to be convinced that violence between religions can be overcome if religious practitioners would realize that their religious rites are in fact varieties of one basic faith: una religio in rituum varietate. In the imaginary story of De pace fidei, the King of heaven and earth receives a number of messengers who bring stories of religious strife and oppression. One of these messengers asks the heavenly King to manifest His face so that the enmity will end, and so all people will know that "there is only one religion in the variety of rites." ${ }^{\text {T }}$ This is the utopian ideal for Nicholas of Cusa: if only God would reveal Godself we would be able to acknowledge that we worship the same God in a variety of rites, and in that case all enmities between religions would cease. Here we come across a fun-

5 De pace fidei 1, 1: "Fuit ex hiis, quae apud Constantinopolim proxime saevissime acta per Turkorum regem divulgabantur, quidam vir zelo Dei accensus, qui loca illarum regionum aliquando viderat, ut pluribus gemitibus oraret omnium creatorem quod persecutionem, quae ob diversum ritum religionum plus solito saevit, sua pietate moderaretur." Latin text reproduced from the Heidelberg critical edition, and English translation by H. Lawrence Bond in: Nicholas of Cusa on Interreligious Harmony. Text, Concordance and Translation of De Pace Fidei, ed. James E. Biechler and H. Lawrence Bond (Lewiston, N.Y.: The Edwin Mellen Press, 1990), 3; hereafter cited as 'trans. Bond.'

6 De pace fidei 1, 6: "Si sic facere dignaberis, cessabit gladius et odii livor, et quaeque mala; et cognoscent omnes quomodo non est nisi religio una in rituum varietate"; trans. Bond, 7 . 
damental notion in the work of Nicholas the philosopher: the idea of learned ignorance. We know that ultimately we do not know God, and that we only know how God is worshipped in a variety of rites. But Nicholas is enough of a (church-)politician to add a healthy dose of realism here, and therefore adds:

But if perhaps this difference of rites cannot be removed or if it is not expedient to do so in order that the diversity may contribute to devotion ... at any rate, just as you are one, there should be one religion and one veneration of worship. ${ }^{7}$

As the editors of De pace fidei have noted, this is a clear allusion to a famous text from the Quran, which we will encounter again in the Cribratio Alkorani. ${ }^{8}$

In the debates between the representatives of the different nations, Nicholas of Cusa immediately broaches this theme of the unity and harmony of religions by letting the oldest representative, a Greek (clearly a reference to the importance of Greek philosophy), address this problem:

We give praises to our God whose mercy is above all his works; he alone is able to cause so great a diversity of religions to be brought into one concordant peace $[. .$.$] Therefore, we beseech you now to instruct us how$ this unity of religion could be introduced by us. ${ }^{9}$

After the Greek and an Italian, the third representative entering the discussion (presided by none other than the Word) is an Arab, who agrees with the others that all human beings by nature desire Wisdom. When he asserts that this Wisdom is the one God, the Word agrees and says: "Therefore, for all those who are of sound understanding there is one religion and worship, which is presupposed in all the diversity of the rites." ${ }^{\prime 10}$ Here the Word gives the formula

7 De pace fidei, "Quod si forte haec differentia rituum tolli non poterit aut non expedit, ut diversitas sit devotionis adauctio, quando quaelibet regio suis ceremoniis quasi tibi regi gratioribus vigilantiorem operam impendet: saltem ut sicut tu unus es, una sit religio et unus latriae cultus"; trans. Bond.

8 See notes 12 and 13 in Biechler and Bond, Nicholas of Cusa on Interreligious Harmony, $222-23$.

9 De pace fidei, 4, 10: "Laudes Deo nostro dicimus, cuius misericordia super omnia opera eius, qui solus potens est efficere quod in unam concordantem pacem tanta religionum diversitas conducatur... Oramus tamen nunc instrui, quo modo haec per nos religionis unitas possit introduci"; trans. Bond, 11.

10 De pace fidei, 6, 16: "Una est igitur religio et cultus omnium intellectu vigentium, quae in omni diversitate rituum praesupponitur"; trans. Bond, 15. See also James E. Biechler, 
in a somewhat elaborate form: "una est igitur religio et cultus ... quae in omni diversitate rituum praesupponitur." It is interesting to note that in these texts Nicholas of Cusa uses both the singular una religio and the plural diversitas religionum so that the word can be an equivalent of the one faith (fides) or worship (cultus) on the one hand, and of the multitude of rites (ritus) on the other. It would be interesting to further investigate this particular-and possibly unprecedented - use of the word religio as both a normative and eschatological ideal and as a description of existing plurality, since it seems to foreshadow much later conceptions of pluralism in the philosophy and theology of religions. ${ }^{11}$ Yet the introduction of a normative notion of orthodox faith to which all religions will be led in the first intervention by the incarnate Word seems to suggest otherwise: "Since truth is one and since it is not possible that it not be understood by every free intellect, all diversity of religions will be led to one orthodox faith."12 As we will see later, this tension between one orthodox faith and the multiplicity of religious rites corresponds to the tension in the Qur'an between the one divine law or religion revealed by God, and the many rites and customs brought by the prophets to the different nations. With this, we turn to the second major text that Nicholas of Cusa devoted to Islam.

While De pace fidei captures Nicholas's first reflection on the Fall of Constantinople, he came back to this event seven years later with a more elaborate theological reflection, in which he once again used the same idea about the variety of rites and the one faith. Having read the Qur'an in its Latin translation, he wanted to help Pope Pius II give a more theological answer to the Fall of Constantinople in the form of a letter to Sultan Mehmet, the Conqueror (al-Fatih) of Constantinople. Nicholas hoped that his Christian interpretation of the Qur'an would show that it in fact supports Christian claims about Jesus Christ, and might consequently convince the Sultan that he should convert to Christianity. In order to substantiate his proposal for a papal letter to the Sultan, Cusanus wrote a long theological treatise. This work, the Cribratio Alkorani or "Sifting of the Qur'an," is often seen as representing a much more polemical approach to Islam than the peaceful setting of De pace fidei. ${ }^{13}$ The literary form

"A New Face toward Islam: Nicholas of Cusa and John of Segovia," in Nicholas of Cusa in Search of God and Wisdom, ed. Gerald Christianson and Thomas M. Izbicki (Leiden: Brill, 1991), 185-202, here 197 .

11 This is what makes Nicholas of Cusa's use of the term ambiguous, according to the editors of Catholic Engagement with World Religions.

12 De pace fidei, 3, 8: "Quae [= veritas] cum sit una, et non possit non capi per omnem liberum intellectum, perducetur omnis religionum diversitas in unam fidem orthodoxam"; trans. Bond, 10.

13 See, among others, Norman Daniel, Islam and the West: the Making of an Image (1st ed. 1960; reprinted Oxford: Oneworld, 1993), 307. 
of this work differs as well, as Sifting of the Qur'an endeavors to approach the holy book of Islam with the mindset of a Christian theologian. However, in this work we come across the same words-'una religio in rituum varietate'-once again, which might indicate that the same form of pluralism is operative here as well. More importantly, Nicholas expressly identifies these words as pertaining to a specific Islamic way of looking at the plurality of messengers, and at the guidance given by God to humankind. Thus, it is this Islamic view on the history of prophecy and revelation that is behind Nicholas's familiar phrase: 'one religion in a variety of rites.'

At the beginning of the first book of the Cribratio Alkorani, Nicholas explains this Islamic point of view on religious plurality as follows:

[Followers of Muhammad] also say that God sent to all nations indigenous messengers and that [through them] He admonished these nations regarding what they had to believe and had to do in order to be numbered, on the day of judgment, among those who are good and in order to attain unto the Paradise full of joy. [. . .] Accordingly [followers of Muhammad] conclude that if the variety of laws and of rites is found to be present in the identity-of-faith that is exhorted within the various nations by the messengers of God, then indeed this [kind of diversity] cannot at all prevent one who is obedient from obtaining a fitting reward at the hands of the most gracious and most just Judge. ${ }^{14}$

Again, we meet here an eschatological vision of interreligious harmony, but this time the diversity is not to be overcome until God speaks the truth in the final judgment, since this variety is meant to teach humankind how to believe and to act faithfully. In a formula that sounds much like the famous words from De pace fidei, Cusanus has the Muslims say that the one faith can be found in the variety of laws and rituals prescribed by the prophets of God to the various nations, though it is intended as a hidden guidance that will be fully uncovered by God on the Day of Judgment. ${ }^{15}$ In the meantime, diversity serves as an incitement to do good, and in this way arrive at eternal bliss.

14 Cribratio Alkorani I, 2, n. 27; Latin text in Nicolai de Cusa Cribratio Alkorani (Opera omnia, vol. VIII), ed. Ludwig Hagemann (Hamburg: Felix Meiner, 1986), 27-28; translation in Jasper Hopkins, Nicholas of Cusa's De pace fidei and Cribratio alkorani: Translation and Analysis (Minneapolis: The Arthur J. Banning Press, 1994), 88.

15 Cribratio Alkorani I, 2, n. 27: "Quare concludunt, quod, si varietas legum vel rituum in identitate fidei in variis gentibus per dei nuntios praecepta reperiatur, hoc quidem oboedienti nequaquam, quominus apud piissimum atque iustissimum iudicem condignum praemium assequatur, obese poterit." 
At this place in the Cribratio Alkorani, Nicholas of Cusa summarizes what Muslims have to say about the Qur'an: it is a book that came down from heaven and tells about the unity of God and the plurality of books and prophets; thus, the Qur'an confirms the various messengers and books given by God before. And indeed, one can find a number of texts in the Qur'an that confirm Cusanus's summary here. A rather famous text from Surat al-Ma'ida (Qur'an 5:48), often mentioned by Muslims as an important source for thinking about religious pluralism, ${ }^{16}$ seems to correspond quite well with what Nicholas has his Muslim interlocutors say:

We have assigned a law (shirah) and a path (minhaj) to each of you. If God had so willed, He would have made you one community (ummatan wahidatan) but He wanted to test you through that which He has given you, so race to do good: you will all return to God and He will make clear to you the matters you differed about. ${ }^{17}$

Hence, the basic view on religious differences in the Qur'an is that God sent different messengers to different nations with their own rites and beliefs in order that they emulate one another in doing good, and God will in the end pass judgment over their differences.

\section{Sources for 'One Faith—Different Rites'}

Yet it would be quite a stretch to assert that Nicholas of Cusa received the inspiration for his idea about the God-given meaningfulness of religious plurality from the Quran. In order to make this assertion plausible, we need to go back from Nicholas of Cusa in the fifteenth century to Peter the Venerable and Hermann of Dalmatia in the twelfth century — one of the first encounters between the world of Islam and the world of the Latin West. From there, we

16 See Muhammad Shafiq and Mohammed Abu-Nimer, "The Qur'anic Perspectives of Interfaith Dialogue," in Interfaith Dialogue: A Guide for Muslims (Herndon, va: The International Institute of Islamic Thought, 2007), 49-84; Reza Shah-Kazemi, The Other in the Light of the One: the Universality of the Qur'an and Interfaith Dialogue (Cambridge: Islamic Texts Society, 2006). Some reflections also in Pim Valkenberg, Sharing Lights on the Way to God: Muslim-Christian Dialogue and Theology in the Context of Abrahamic Partnership (Amsterdam-New York: Editions Rodopi, 2006), 152-62.

17 Qur'an 5:48 in the interpretation by M. A. S. Abdel Haleem, The Qur'an: English Translation and Parallel Arabic Text (Oxford: Oxford University Press, 2010), 117. I added a transliteration of the most important Arabic words in this text. 
need to go back even further to 'Abdallah ibn Salām, believed to be an early Jewish convert to Islam in the seventh century, and finally, we will come to none other than Prophet Muhammad himself, in conversation with 'Abdallah ibn Salām.

We begin with Nicholas of Cusa and his copy of the Qur'an. In the introduction to the Cribratio Alkorani, Nicholas states that he made quite an effort to obtain a good Latin translation of the Qur'an. ${ }^{18}$ Since he could not read Arabic and his efforts to commission a Latin translation failed, in the end he had to settle for the twelfth-century translation by Robert of Ketton. This work was part of the so-called Toledan Collection, a number of translations commissioned by Peter the Venerable, Abbot of Cluny, in Toledo around 1140. ${ }^{19}$ Interestingly, Peter's translation project was inspired by the same idea as Nicholas' De pace fidei: to prefer the battle of words over the battle of arms - the Crusades-as reaction to the emerging political power of Islam. ${ }^{20}$ The Toledan collection was for a long time the main instrument for the Christian West to become acquainted with the world of Islam. Thus, it has been reprinted many times since its first printing in 1543 by the Reformed theologian Theodor Buchmann (or Bibliander) in Basel, with introductory essays by Martin Luther and Philipp Melanchthon. ${ }^{21}$ Writing a century before that though, Nicholas of Cusa used a manuscript copy of the collection, which can still be consulted today since it has been preserved in his own personal library as Codex Cusanus 108. James Biechler has made a careful study of this manuscript and has ventured the hypothesis that Nicholas studied the Qur'an and other writings associated with it, making notes in the margin of these works at least three times. ${ }^{22}$ The first notes date from the period in which Nicholas worked as a young canon

18 Cribratio Alkorani, prologue, nn. 2-4; translation in Hopkins, 75-76.

19 See James Kritzeck, Peter the Venerable and Islam (Princeton: Princeton University Press, 1964).

20 Kritzeck, Peter the Venerable and Islam, 21. For a similar comparison, see Rita GeorgeTvrtković, "After the Fall: Riccoldo da Montecroce and Nicholas of Cusa on Religious Diversity," Theological Studies 73 (2012): 641-62.

21 Kritzeck, Peter the Venerable and Islam, viii. A somewhat later edition from $155^{\circ}$ is reproduced on the internet by the Bibliothèque Nationale de France: gallica.bnf.fr. The first part of the title in Latin is: Machumetis Saracenorum principis ejusque successorum vitae, doctrina, ac ipse Alcoran. The text was reprinted by Les Mondes Humanistes (GRAC-UMR 5037) in 2010.

22 See James E. Biechler, “Three Manuscripts on Islam from the Library of Nicholas of Cusa," Manuscripta 27 (1983): 91-100. 
lawyer in Basel. ${ }^{23}$ The second series of notes is connected with the composition of De pace fidei in 1453, while the last series of notes is related to the meticulous preparation of the Cribratio Alkorani in 1460-61. One of the notes in the second series is of particular interest, since it seems to indicate the origins of the famous words, 'religio una in rituum varietate.' It is a note, together with a hand pointer, on fol. 25 of Codex Cusanus 108, which reads: "fides una, ritus diversus. ${ }^{24}$ Now, the work that inspired Nicholas to write this note was not the Latin translation of the Quran by Robert of Ketton, but rather an obscure Islamic treatise that formed part of the Toledan Collection, entitled Lex sive Doctrina Machumet (Law or Teaching of Muhammad) and translated by Hermann of Dalmatia in $1143 .{ }^{25}$

It is next to this text on the teaching of Muhammad that Nicholas of Cusa wrote 'fides una, ritus diversus.' Biechler comes to the conclusion that

Cusanus's note seems to be the root of his principle 'religio una in rituum varietate' expressing his theoretical solution to the problem of the world religions: there is really only one religion existing in a variety of rites or forms. ${ }^{26}$

Ludwig Hagemann, the German medievalist and editor of the Cribratio Alkorani, is even more outspoken about the importance of this marginal note, claiming: it is of great importance and without a doubt shows the source and origin of the phrase 'religio una in rituum varietate. ${ }^{27}$ The emphasis on Muslim sources in Hagemann's remark makes sense if one links the discussion about the origins of the famous phrase 'una religio in rituum varietate' to the history of its reception in the twentieth century. Various scholars have connected these words instead with neo-Platonic and other philosophical backgrounds, as well

23 For biographical information, see Erich Meuthen, Nicholas of Cusa: A Sketch for a Biography, trans. D. Crowner and G. Christianson (Washington, D.C.: The Catholic University of America Press, 2010).

24 Biechler, "Three Manuscripts," p. 94; Biechler, "Interreligious Dialogue," in Introducing Nicholas of Cusa: A Guide to a Renaissance Man, ed. C. Bellitto, T. Izbicki and G. Christianson (New York-Mahwah, N.J.: Paulist Press, 2004), 270-96, here 279.

25 See Guillaume Frédéric Pijper, Het boek der duizend vragen (Leiden: Brill, 1924), 4.

26 Biechler, "Three Manuscripts," 94-95.

27 Cribratio Alkorani 223, in note 77 on the text quoted earlier, I, 2, n. 27: "Verba fides una, ritus diversus' a Nicolao in margine adscripta magni ad illam Nicolai sententiam 'religio una in rituum varietate' (De pace 1 n.6) momenti sunt. Si quaeremus, quibus e fontibus ea doctrina hausta sit, dubium non potest esse, quin Doctrina fons et origo illius sententiae sit...." 
as with Catholic and other forms of ecclesiology. ${ }^{28}$ Against this tradition, I agree with Hagemann that a reference to Islamic sources makes much more sense if the formula is used by Nicholas in both De pace fidei and Cribratio Alkorani, and if it is used in the latter book in an explicit reference to what defenders of the Qur'an say. Yet the marginal note in itself does not necessarily indicate that Nicholas derived the formula from the Doctrina Machumet; he might simply have recognized a formula that he had met before as a student of canon law or conciliar history, as Erich Meuthen observes in a note on the historical sources of the formula. ${ }^{29}$ Yet Biechler's remark on the threefold series of notes in Cusanus's copy of the Toledan Collection suggests an even more interesting possibility, namely, that Nicholas noticed the formula for the first time in several sources when he was a student and young practitioner of canon law, but that this knowledge was activated when he went through the Collectio Toletana for the second time, looking for a solution to the problem of religious plurality occasioned by the Fall of Constantinople.

In any case, the presence of the hand pointer and the marginal note makes a strong case for an Islamic notion of unity-in-plurality behind the formula 'one faith, different rites,' which would have such a lasting influence through its rephrasing in De pace fidei. In order to see what exactly this Islamic notion of unity-in-plurality might be, we need to look at the Arabic text that was translated by Hermann of Dalmatia, one of the assistants of Peter the Venerable in the 1140s. The work is known in its Arabic original as the Kitāb al-masāill, or "Book of questions," attributed to 'Abdallah ibn Salām. The genre of this book is well known in early Islamic apologetics: a group of Jews (or Christians) comes to Prophet Muhammad and poses him some questions whose answers, according to their tradition, are known only to a true prophet. It is the goal of apologetic works such as these to show that the Jews in the text converted to Islam because Muhammad, being a true prophet, knew all the right answers,

28 For two good examples, see Maurice de Gandillac, "Una religio in rituum varietate," in Nikolaus von Kues als Promotor der Ökumene, ed. R. Haubst, Mitteilungen und Forschungsbeiträge der Cusanus-Gesellschaft, 9 (1971): 92-105; Michael Seidlmayer, "'Una religio in rituum varietate': zur Religionsauffassung des Nikolaus von Cues," Archiv für Kulturgeschichte 36 (1954): 145-207.

29 See Erich Meuthen, "Der Dialogus concludens Amedistarum errorem ex gestis et doctrina concilii Basiliensis," Mitteilungen und Forschungsbeiträge der Cusanus-Gesellschaft 8 (1970): 11-114, here 58-62. During the conference of the American Cusanus Society in Gettysburg in October 2012, Walter Euler remarked that Cusanus seems to use the formula about the one religion and the many rites already in his conversation with Bohemian (Hussite) representatives to the Council of Basel. See Meuthen, Nicholas of Cusa, 38-39. 
thereby suggesting that Jews who are confronted with this apology should do the same.

Even though the name of 'Abdallah ibn Salām is mentioned quite a few times in early Islamic sources, we do not currently possess a reliable Arabic text attributed to him. The reason is that the genre of the 'questions' lends itself to additions and changes, since later copyists and editors tended to add their own questions as well. Therefore, the Latin text translated by Hermann of Dalmatia is often considered to be the most reliable textual basis of this work. ${ }^{30}$ In this paper, I will first look at the significance of 'Abdallah ibn Salām in early Islamic sources; next, I will look at the Latin text that Nicholas of Cusa used; and finally, I will compare that text to a later-and unreliable-Arabic text version in order to see what exactly the Arabic terms could have been that occasioned Nicholas to write his note 'fides una-ritus diversus,' later reformulated as 'religio una in rituum varietate.'

'Abdallah ibn Salām is one of the few Jews who are looked upon favorably in early Islamic sources. The earliest source that mentions him is probably Ibn Ishaq's biography of Prophet Muhammad, written about two centuries after the death of the Prophet. In this biography (as handed down in the later version by Ibn Hisham), Ibn Ishaq mentions 'Abdallah ibn Salām, together with three other Jews, as rabbis who came to the true faith of Islam. Ibn Ishaq mentions this example as an explanation of the following verses in surah Al Imran (3:113-114):

They are not all alike; of the scripture folk there is an upright community who read God's verses in the night season prostrating themselves. They believe in God and the last day and enjoin good conduct and forbid evil and vie with one another in good works. They are the righteous. ${ }^{31}$

A little before that, Ibn Ishaq had told the conversion story of 'Abdallah ibn Salām in the following words:

I was told the story of 'Abdullah b. Salām, a learned rabbi, by one of his family. He said: 'When I heard about the apostle I knew by his descrip-

30 Pijper, Het boek der duizend vragen, 40. Kritzeck, Peter the Venerable and Islam, 73-74, describes a manuscript (MS 1162 of the Bibliothèque de l'Arsenal) that he believes to be the original Toledan Collection, written in Spain before 1150 and bound in Cluny shortly thereafter.

31 Quoted according to the English translation by A. Guillaume in The Life of Muhammad: A Translation of Ishaq's Sīrat Rasūl Allāh (Oxford-New York: Oxford University Press, 1955), 262. 
tion, name, and the time at which he appeared that he was the one we were waiting for, and I rejoiced greatly thereat, though I kept silent about it until the apostle came to Medina. When he stayed in Qubä' among the b. 'Amr b. 'Auf a man came with the news while I was working at the top of a palm-tree and my aunt Khālida b.al-Hārith was sitting below. When I heard the news I cried Allah Akbar and my aunt said: "Good gracious, if you had heard that Moses b. Imrān had come you could not have made more fuss!" "Indeed, aunt," I said, "he is the brother of Moses and follows his religion, being sent with the same mission." She asked, "Is he really the prophet who we have been told will be sent at this very time?" and she accepted my assurance that he was. Straightway I went to the apostle and became a Muslim, and when I returned to my house I ordered my family to do the same.

I concealed the matter from the Jews and then went to the apostle and said, "The Jews are a nation of liars and I wish you would take me into one of your houses and hide me from them. Then ask them about me so that they may tell you the position I hold among them before they know that I have become a Muslim. For if they know it beforehand, they will utter slanderous lies against me." The prophet housed me; the Jews came; and the apostle asked them about my standing among them. They said: "He is our chief and the son of our chief; our rabbi, and our learned man." When they said this, I emerged and said: "O Jews, fear God and accept what He has sent you. For by God you know that he is the apostle of God. You will find him described in your Torah and even named. I testify that he is the apostle of God, I believe in him, I hold him to be true, and I acknowledge him." They accused me of lying and reviled me. Then I reminded the apostle that I had said that they would do this, for they were a treacherous, lying and evil people. I publicly proclaimed my conversion and my household and my aunt Khālida followed suit. ${ }^{32}$

This rather long story teaches us three things about the relationship between the first Muslims and the Jewish community. First, the story functions as part of the anti-Jewish polemics in Medina, where a large majority of the important Jewish population was not ready to accept Muhammad as a prophet. In this context, the Qur'an and early Islamic tradition argue that most Jews are not to be trusted, in part because they do not read their own Scriptures properly. Second, as the text just quoted from the Qur'an mentions, there is a minority among the Jews who do know how to read the Scriptures and the signs of the times. They are the upright and the just ones, but they are of course 
also the ones who convert to Islam. Thus, 'Abdallah ibn Salām is portrayed as a leader of this community: he is the most learned scholar, and is able to read the announcement of the future prophet in the Jewish Scriptures. Finally, 'Abdallah ibn Salām is portrayed as someone who does not need to be convinced, as he just goes to Muhammad and converts to Islam. In fact, as later Muslims would say, he does not convert but he reverts to his true nature ( fitra) as muslim, someone who submits himself freely and willingly to God.

This final characteristic, viz. that 'Abdallah ibn Salām immediately converts without further questions, changes in subsequent traditions. The later traditions about the 'questions' posed by Ibn Salām to the Prophet have their origin in a hadith (a traditional story about Muhammad and his first followers) transmitted by Bukhari in the context of the stories of the prophets, in which the story about Ibn Salām serves to highlight the prophethood of Muhammad. Bukhari recounts:

Narrated Anas: when 'Abdullah ibn Salam heard of the arrival of the Prophet at Al-Madina, he came to him and said: "I am going to ask you about three things which nobody knows except a Prophet: (1) What is the first portent of the Hour? (2) What will be the first meal taken by the people of Paradise? (3) Why does a child resemble its father, and why does it resemble its maternal uncle?" Allah's messenger said: "Jibrael (Gabriel) has just now told me of their answers." "Abdullah said: "He, from amongst all the angels, is the enemy of the Jews." Allah's Messenger said: "The first portent of the Hour will be a fire that will collect the people from the east to the west; the first meal of the people of Paradise will be extra lobe (caudate lobe) of fish-liver. As for the resemblance of the child to its parents: If a man has sexual intercourse with his wife and gets discharge first, the child will resemble the father, and if the woman gets discharge first, the child will resemble her. On that, 'Abdullah bin Salam said: "I testify that you are the Messenger of Allah." 'Abdullah bin Salam further said: "O Allah's Messenger! The Jews are liars, and if they should come to know about my conversion to Islam before you ask them (about me), they would tell a lie about me." The Jews came to Allah's Messenger and 'Abdullah went inside the house. Allah's Messenger asked (the Jews) "What kind of man is 'Abdullah bin Salam amongst you?" They replied, "He is the most learned person amongst us, and the best amongst us, and the son of the best amongst us." Allah's Messenger said: "What do you think if he embraces Islam?" The Jews said: "May Allah save him from it." Then 'Abdullah bin Salam came out in front of them saying, "I testify that La ilaha ill-Allah (none has the right to be worshipped but Allah) and 
Muhammad is the Messenger of Allah." Thereupon they said, "He is the most wicked among us, and the son of the most wicked among us," and continued talking badly of him. ${ }^{33}$

A new element in this hadith is the enmity between the Jews and Jibrill or Gabriel, the angel that functions as an important messenger of God and mediator of God's revelation in Islam and Christianity. Ibn Kathīr, who uses stories from the hadith collections many times to interpret the Quran, uses this particular story to explain the meaning of the Qur'anic verse: "Whoever is an enemy to Jibril, because he has brought it [the Qur'an] down to your heart."34 Yet this new element serves to underline the common point in the two stories, which is the trustworthiness of 'Abdallah ibn Salām in contrast to the moral depravity of most other Jews. 'Abdallah ibn Salām is so noteworthy precisely because he represents an exceptional case of a trustworthy Jew who converts to Islam. This same point is made in an English translation of the Qur'an published by the same publishing house from Saudi Arabia, where the reference to 'Abdallah ibn Salām is even translated into the text, with a footnote that gives the text just quoted from Bukhari. ${ }^{35}$ Hence, it is clear that in a traditional Islamic reading of the Qur'an, 'Abdallah ibn Salām is well known as one of the few Jews who converted to Islam because he believed in the prophethood of Muhammad. Consequently, according to another tradition, Ibn Salām is praised by Muhammad as one of the 'men of paradise.'36

33 Quoted with some omissions from Summarized Sahîh Al-Bukhâri Arabic-English, translated by Dr. Muhammad Muhsin Khan (Riyadh: Darussalam, 1996/1417), no. 1400, 658-59 (no. 4:546 in the original Sahîh Bukhâri).

34 See Tafsir ibn Kathir, abridged, vol. I (Riyadh: Darussalam, 2003), 305, with reference to Qur’an 2:97.

35 In this translation, Qur'an 5:66 goes as follows: "And if only they had acted according to the Taurāt (Torah), the Injil (Gospel), and what has (now) been sent down to them from their Lord (the Qur'ān), they would surely, have gotten provision from above them and from underneath their feet. There are from among them people who are on the right course (i.e. they act on the Revelation and believe in Prophet Muhammad ... as 'Abdallah bin Salam...), but many of them do evil deeds." Quoted from Dr. Muhammad Muhsin Khan and Dr. Muhammad Taqi-ud-Din Al-Hilali, Interpretation of the Meanings of the Noble Qurân in the English Language (Riyadh: Darussalam, 1996), 165-66.

36 The tradition is in the collection by Muslim. For the reference, see Ronit Ricci, "A Jew on Java, a Model Malay Rabbi and a Tamil Torah Scholar: Representations of Abdullah Ibnu Salam in the Book of One Thousand Questions," Journal of the Royal Asiatic Society, series 3/18 (2008): 481-95. 
The importance of 'Abdallah Ibn Salām for early Islamic apologetics comes into focus by a remark often repeated in early Muslim sources, namely, that Jews seldom convert to Islam while Christians convert-or, as Muslims would say, revert - to Islam more frequently. The traditionalist Ibn Kathir, for instance, explains in reference to Qur'an 3:199: "There are, certainly, among the People of the Scripture, those who believe in Allah and in that which has been revealed to them, humbling themselves before Allah": "These qualities exist in some of the Jews, but only a few of them. For instance, less than ten Jewish rabbis embraced the Islamic faith, such as 'Abdullāh ibn Salām. Many among the Christians, on the other hand, embraced the Islamic faith."37

Sometimes 'Abdallah ibn Salām is mentioned by name with reference to places where the Quran talks about some of the People of the Book who accepted the revelation brought to Muhammad. For instance, Al-Wāhidi, in his Asbāb al-Nuzūl (the traditional work on the "Occasions of the Revelations"), connects 'Abdallah with the following verse: "Those unto whom We gave the Scripture recognize (this revelation) as they recognize their sons" (Qur'an 2:146). Furthermore, he states:

This was revealed about the believers of the People of the Book: 'Abd Allah ibn Salam and his companions ... Said 'Abd Allah ibn Salam: 'I knew Allah's Messenger ... better than I knew my son.38

Other reports tell how 'Abdallah still observed the customs of the Torah after becoming a Muslim, so that he is mentioned as an authority about a number of Jewish customs, the so-called Isra'iliyyāt. ${ }^{39}$

Because of Ibn Salām's important function as one of the few people who connected the values, customs, and expectations of Judaism with the religion of Islam in a positive way, his name was associated with a much later literary tradition in which the questions he posed to Muhammad became the nucleus of an extended series of questions that were to show the truth of the Islamic

Tafsīr ibn Kathir, abridged, II (Riyadh: Darussalam, 2003), $35^{8}$.

38 See Mokrane Guezzou, trans., Al-Wāhidìs Asbāb al-Nuzūl, Great Commentaries on the Holy Qur’an, vol. III (Louisville, KY: Fons Vitae, 2008), 18.

Other places where Abdallah is mentioned as one of the believers from the People of the Book are Qur'an 3:113 and 4:136. See Al Wahidi, Asbāb al-Nuzūl, 56 and 88. For the tafsìr concerning Qur'an 3:113 ("There are among the People of Scripture an upright community reciting God's revelations through the watches of the night as they bow down"), see also Mahmoud Ayoub, The Qur'an and Its Interpreters, vol. II: The House of Imran (Albany: State University of New York Press, 1992), 296-300. 
faith in answer to Jewish (and other) questions of several kinds. This tradition developed in many forms, ${ }^{40}$ one of which was translated by Hermann of Dalmatia into Latin, the language in which Nicholas of Cusa came to read it in his copy of the Toledan Collection.

Hermann of Dalmatia's Doctrina Mahumet describes how while in Medina, Muhammad is informed by Gabriel that a delegation of four Jewish religious leaders, led by 'Abdia iben Salon' ('Abdallah ibn Salām), is about to visit him. ${ }^{41}$ Abdia explains that he has come to question Muhammad about things that are not clear in their Jewish faith. The first question is: "Are you a prophet (propheta) or a messenger (nuncius)?" Muhammad replies: "God has made me both a prophet and a messenger." Next, Abdia asks: "Do you preach your law or the law of God (lex Dei)?" When Muhammad answers that he preaches the law of God, Abdia asks what this law is, and Muhammad answers: "Faith (fides)." When asked which faith, Muhammad responds with the two basic tenets of monotheism and resurrection of the dead. Abdia then asks: "How many laws of God are there?" Muhammad responds: "There is one law of God." "But what about the prophets that have come before you?" asks Abdia, to which Muhammad replies: "The law or the faith of the prophets is one, but the rites of the different ones were of course different" (Lex quidem, siue fides, omnium una, sed ritus diuersorum nimirum diuersi). The discussion then goes on about whether people can attain paradise by faith, by certain beliefs, or by works (pro fide, aut credulitate, aut pro opere). This discussion in the Doctrina Mahumet comes close to the context and the terminology of Qur'an 5:48 (surah al-Maida), which Nicholas of Cusa quoted at the beginning of his Cribratio Alkorani: God could have made us one community, but He has given us different rites and customs in order for us to rival one another by doing good, and in the end God will pass judgment about the differences.

After this short discussion about these fundamental issues in Islamic theology, the Latin text of the Doctrina Mahumet continues with a discussion of the book that Muhammad claims to have received from God, and then it goes on with a number of seemingly disconnected issues: questions about the meaning of numbers, about God's creation of the heavenly bodies, and riddles such as "what woman came forth only from a man, and what man only from a woman?" What these seemingly disparate matters have in common is that regular human beings do not know the truth about them, but a true prophet

\footnotetext{
$40 \quad$ See Pijper, Het boek der duizend vragen, and Ricci, "A Jew on Java."

41 In the following paragraph, English paraphrases are mine; the Latin words are from the Bibliander edition on the internet, http://gallica.bnf.fr/ark:/12148/bpt6k114531g/f214. image; see footnote 21), fol. 189-190.
} 
would know how to answer the questions and riddles. Since Muhammad succeeds in responding to Abdia's challenges, the Jewish delegation accepts that he is a true prophet and consequently converts to Islam. This means that the remark about the one law of faith and the diversity of rites also functions in the context of what we may call Islamic 'prophetology,' which has always been one of the foremost issues in dialogues and apologetics between Muslims and Jews, for instance in the Kuzari by Judah Halevi. ${ }^{42}$

In order to find out what the phrase in Islamic theology was that Hermann of Dalmatia translated as 'Lex quidem, siue fides, omnium una, sed ritus diuersorum nimirum diuersi,' it would be nice if one could go back to the Arabic text of the Masāill. Unfortunately, though, the history of the genre of apologetic 'questions' is very complicated, and so we do not possess any original form of the text or any critical edition. ${ }^{43}$ I have been able to read one version of an Arabic text attributed to Ibn Salām on the Internet, which represents a much later adaptation of the text and reflects a stricter form of Islamic apologetics than the text translated by Hermann of Dalmatia. However, one may assume that the basic concepts have been preserved, even if the theological context in this Arabic version represents a later development.

When going back to the Arabic roots of the Latin phrase about the one lex or fides and the diversity of ritus, one will find that it matches perfectly with Islamic prophetology: Muslims believe in a plurality of prophets and scriptures, because God has revealed God's guidance at different times to different nations that each have their own rites. Yet, at the same time, there is only one true faith, which is - in accordance with the apologetic style of this Arabic adaptation-immediately identified with the religion of Islam. In answer to 'Abdallah Ibn Salām's question about the message that he brings as prophet and messenger, we find Muhammad saying, according to the Arabic text:44 "There is one din" - a word that is usually translated as 'religion,' but 'Law' is possible as well because the word refers to the 'Law of God.' In medieval Latin, the word lex is often used where modern readers would expect 'religion. ${ }^{\prime 5}$ Muhammad

42 See the introductory remarks by Barbara Roggema, Marcel Poorthuis, and Pim Valkenberg in The Three Rings: Textual Studies in the Historical Trialogue of Judaism, Christianity and Islam (Leuven: Peeters, 2005).

43 See Kritzeck, Peter the Venerable and Islam, 89.

44 I quote a contemporary Arabic version on the Internet, which represents a more advanced stage of Islamic theology, as most Arabic text versions do (see Pijper, Het boek der duizend vragen, 39.) The text quoted can be found on: cb.rayaheen.net/showthread. php?tid=27739.

45 I want to thank Dr. Thomas Burman for bringing this to my attention during the conference of the American Cusanus Society in Gettysburg, October 2012. The very title of Hermann of Dalmatia's translation, Lex sive doctrina Mahumeti, is a case in point. 
continues: "The religion of the prophets was the pure religion of God, the religion of His angels, and the religion of Islam."46 When 'Abdallah ibn Salām then asks how many religions (or Laws) of God there are, Muhammad answers: "One religion, and that is Islam." ${ }^{47}$ In this later adaptation of the text, the word islām in Arabic is interpreted as referring to the institutionalized religion of Islam rather than to an attitude of faith, of submitting (or rather, aligning) oneself to God's will and guidance. But in older text versions of the Masāill, the attitude of faith might be the subject under discussion, since the text makes the famous distinction between isläm as the enacting of the five pillars, and imān (belief) as holding the six basic tenets of the faith. ${ }^{48}$

After this discussion, Abdallah wants to know how many paths or ways there are- the question 'how many?' refers back to similar questions concerning the number of prophets. He uses the Arabic word shir'ah, which literally refers to a path to the water well, which is essential for survival in the desertthe word shariah is derived from the same root. ${ }^{49}$ Muhammad answers: "There were different paths (or laws) with the peoples of the past." ${ }^{20}$ So we have two words, din and shir'ah, that can both be translated as 'law,' and it is precisely this ambiguity that defines the issue at hand between Abdallah and Muhammad. It creates a tension that is germane to Islamic theology: there are many customary laws (plural: shara $\bar{a} i$ ), while at the same time there is only one Law of God. Again, in the context of Jewish-Muslim dialogue one is reminded of the role of Jewish halakhah, the 'way to walk' and enact the Torah of God.

The theology in this Arabic text is clearly not pluralist, as it immediately identifies the one religion or din of the prophets with the established religion of Islam. However, one can still recognize the Quranic theology of religions from surah al-Maida (5:48) here, in the verse that gave Nicholas of Cusa occasion to make his remark about fides una, ritus diversus in his Cribratio Alkorani: "If God had willed, He could have made you one community, but He has given each of you a law and a way, ${ }^{51}$ and He will judge about the differences on the day of the resurrection." So, fides una, ritus diversus is a translation of din wāhid, sharā'i' (or manāhij) mukhtalifa: there is one religion revealed by God,

على دين الله الخالصودين ملائكتهودين الإسلام 46

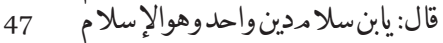

48 This distinction goes back to the famous "hadith of Gabriel" quoted by Muslim and Bukhari in the "book of faith" in their hadith collections. The famous book by Sachiko Murata and William C. Chittick, The Vision of Islam (St. Paul, MN: Paragon House, 1994) is built around the distinction between islam, iman and ihsan according to this hadith. كركانت الشرائع

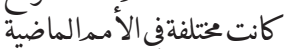

$5^{1} \quad$ Murata and Chittick, The Vision of Islam, 133, translate: "We have appointed a right way and an open road." 
but there are different ways or customs or rites in which this religion is enacted by the different peoples. ${ }^{52}$ In Nicholas of Cusa's De pace fidei, this ambiguity of the notion of Law (din in the singular, or sharä $\imath^{\prime}$ in the plural) translates into an ambiguity in the notion of religion (lex / fides / cultus / religio in the singular; ritus / religiones in the plural). This translation is possible, however, because both in the Qur'anic theology of religions and in Cusanus's Christian theology of religions, there is an identity-in-tension between the one proper religion willed by God as the ultimate destination of humankind, and the diversity of religions willed by God as a way to learn from one another and to reach peace and harmony between religions, which is the horizon of the eschatological vision in De pace fidei.

$5^{2}$ Michel Cuypers, The Banquet: A Reading of the Fifth Sura of the Qur'an (Miami, Fl: Convivium, 2009), 242 remarks that the word minhaj ('path') in 5:48 "in its technical meaning of 'religious custom,' way of life, is borrowed from rabbinical language." The same is true for the entire Masā'il: Muhammad responds to Jewish questions about religion and laws. 


\title{
Divine Difference and Religious Unity: On the Relation Between De Docta Ignorantia, De Pace Fidei and Cribratio Alkorani
}

\author{
Knut Alfsvåg
}

Nicholas Cusanus is commonly known as a promoter of religious dialogue and tolerance. His phrase 'religio una in rituum varietate' is often quoted ${ }^{1}$ and interpreted as an anticipation of a goal of peaceful coexistence, ${ }^{2}$ which certainly is not realized, but has become even more important now than it was five hundred years ago when Cusanus wrote De pace fidei, his book on the peaceful unity of different faiths. This is not to say that it was unimportant then. Cusanus wrote the book from which the aforementioned quotation is taken within a few months of receiving the news of the Muslim Turks' conquest of Constantinople, a conquest that meant the end of a Christian empire with a history of more than a thousand years, and within whose borders were, or had been, the historical sites of the origins of the Christian faith. ${ }^{3}$ Furthermore, with news of the conquest there followed the all-too-common stories of persecution and violence. If we think that the relationship between Christians and Muslims is difficult today, we probably cannot even begin to understand the

1 The quotation is from De pace fidei I, 6. For the Latin text of this work, see Nicolaus Cusanus, Opera omnia, ed. Heidelberger Akademie der Wissenschaften, vol. VII (Hamburg: Meiner, 1932ff). All Cusanus citations will be to the Opera omnia by title, book (where applicable), chapter, and paragraph number. For Jasper Hopkins' useful English translations of Cusanus's works, see Nicholas of Cusa, English translations, accessed 30 April, 2012, http://jasperhopkins.info/.

2 See, e.g., David J. Bosch, Transforming mission: Paradigm shifts in theology of mission (Maryknoll, N.Y.: Orbis Books, 1991), 475. The story of the loss of interest in Cusanus's work and the rediscovery of its significance by Lessing is told in Raymond Klibansky, "Die Wirkungsgeschichte des Dialogs De pace fidei," in Der Friede unter die Religionen nach Nikolaus von Kues, ed. Rudolf Haubst, Mitteilungen und Forschungsbeiträge der CusanusGeselleschaft 16 (1984): 113-125; cited hereafter as Friede unter der Religionen.

3 For an overview of the historical context of Cusanus's works on religious dialogue, see James E. Biechler, "Interreligious Dialogue," in Introducing Nicholas of Cusa: A Guide to a Renaissance Man, ed. Christopher M. Bellitto, Thomas M. Izbicki, and Gerald Christianson (New York: Paulist Press, 2004), 270-296. 
feeling of catastrophe that filled the Christians when they heard the news of the fall of Constantinople. They had fought for centuries to avoid this outcome, and now it was the new reality with which they had to cope. What to do now? Was there anything to do beyond calling for a new crusade, thus attempting to reverse the apparently unavoidable process of history? ${ }^{4}$

There was, however, an alternative, a peaceful approach, and Cusanus is among its best-known proponents. He was an unlikely candidate though, ${ }^{5}$ as he represented the only remaining politically powerful Christian institution in Western Europe: the Catholic Church. As one of its cardinals, he had a vested interested in maintaining its integrity and position as a power player on the international scene, and as an expert of church law and administration, he was well aware of the significance of the ongoing power struggle between the Christian and Muslim empires. Although he had a broader intellectual orientation than many of his contemporaries, it was still one-sidedly Christian, though it did include a familiarity with the tradition of the Eastern Church, which must have let him feel the anguish of what happened in Constantinople to an even greater extent than most. ${ }^{6}$ Still, he seems to have been opposed to the idea of a new crusade, and advocated instead for a peaceful approach to the problem of religious plurality, an approach that emphasized the need for informed dialogue and discussion, with the explicit goal of promoting understanding and unity among the adherents of different religions.

Why did Cardinal Nicholas choose this approach? What was it in his intellectual history that led him along this alternative path? Was it possible for him to promote religious tolerance and dialogue without compromising his position as a representative of the Christian church? Moreover, was he consistent in maintaining his position, and thus presumably representing a theological and philosophical approach to the problem of religious diversity that could be of interest even in a contemporary perspective? Or do his writings reveal compromises and adjustments that make his approach appear more as a haphazard collection of incoherent ad hoc statements? The problem of religious

4 This is what Pope Nicholas V did; see Biechler, "Interreligious Dialogue," 281.

5 For introductions to Cusanus's biography, see Donald F. Duclow, "Life and Works," in Introducing Nicholas of Cusa: A Guide to a Renaissance Man, ed. Christopher M. Bellitto, Thomas M. Izbicki, and Gerald Christianson (New York: Paulist Press, 2004), 25-56; Erich Meuthen, Nicholas of Cusa: A Sketch for a Biography (Washington, D.C.: Catholic University of America Press, 2010).

6 This personal background for Cusanus's work with the unity of religions is emphasized in M. de Gandillac, "Das Ziel der una religio in varietate rerum," in Friede unter die Religionen, 192-204, especially 193. 
pluralism has not left us, and neither has the danger of it being exploited by violent extremists of differing persuasions. ${ }^{7}$ Thus, the question begs to be asked: could the fifteenth-century cardinal have something to say that is still worth exploring by us today, in the twenty-first century?

I will try to answer these questions by first presenting the approach to the problem of religious pluralism that is found in Cusanus's first important theological and philosophical work, De docta ignorantia, ${ }^{8}$ written more than ten years before the fall of Constantinople. Next, I will investigate how far this approach informs what is probably his best-known work in this area, De pace fidei (1453). Finally, I will look at Cribratio Alkorani, a considerably more detailed investigation of Islam that Cusanus wrote in $1461 .{ }^{9}$ This will hopefully give us an overview of the basic elements of Cusanus's understanding of religion, and will consequently allow for a conclusion concerning how far these elements remained constant throughout Cusanus's career.

\section{The Presence of the Infinite as Christian Theology}

The starting point of Cusanus's philosophy of religion is the close connection he finds between God and the idea of infinity. ${ }^{10}$ This has two immediate consequences that orient all he has to say on God and on God's relation to the world. Firstly, there can only be one infinity, since to be counted, entities must be limited in relation to each other and thus cannot be infinite. Hence, there can only be one infinite God, and accordingly, monotheism is established as the only appropriate kind of theology. Secondly, there is no proportionality between the finite and the infinite; thus, relations that presuppose proportionality (and for Cusanus that includes both purpose and causality) are from the outset disabled as possible avenues of thought in exploring the relation between God and the world. Therefore, God cannot be considered either as the end or the

While I am writing this, we have in Norway commemorated the anniversary of the massacre in Oslo and at Utøya in July 2011, when 77 persons were murdered as a protest against the allegedly devastating influence of Islam on Christian Europe. theologische Werke, 4 vols. (Hamburg: Felix Meiner Verlag, 2002), vol. 1 (Latin text with German translation).

9 Cusanus, Opera omnia, vol. VIII.

10 For a more extensive presentation of the thought world of De docta ignorantia and the relevant research, see Knut Alfsvåg, What No Mind Has Conceived: An Investigation of the Significance of Christological Apophaticism (Leuven-Paris-Walpole: Peeters, 2010), $126-146$. 
cause of worldly events, in analogy with the relationships between finite phenomena; ergo, the teleological and cosmological proofs of God's existence fail.

Cusanus therefore finds participation to be the only possible concept that lets one explore the relation between God and the world in a way that lets both maintain their integrity. Thus, the finite participates in infinity by having its very finitude defined by infinity, which neither conflates the two nor reduces one to the other. ${ }^{11}$ Infinity is therefore present in the finite world as that which determines its finitude, and the finite manifests its finitude through participation in the infinite.

This is an approach that in Cusanus's view is easily aligned with biblical monotheism. ${ }^{12}$ But he is also open to the possibility that this understanding of the infinite as present within, but not reducible to, finite phenomena might also be found within pagan religions. Admittedly, pagans tend to conflate divinity with its manifestations, thus committing the sin of idolatry by worshipping finite phenomena as divine, instead of considering them as transparent to but never identical with infinity. But they do not necessarily do so. ${ }^{13}$ Cusanus thus upholds the philosophical and biblical criteria for distinguishing between idolatry and true worship, but without insisting that idolatry is a sin that all pagans necessarily commit.

There are reasons, though, for the traditional identification of paganism with idolatry, and in Cusanus's view, the main reason is that the two central Christian doctrines of Trinity and Incarnation make the Christian faith unique precisely in the way it understands the relation between God and the world. All phenomena in the finite world are characterized by alterity (or otherness) and inequality; if not, they cannot be explored as finite phenomena. But oneness logically precedes alterity, and is ipso facto eternal. In the same way, equality also manifests eternity by preceding all inequality. Oneness, equality, and their union are thus all eternal and manifest the same infinity. God is therefore not only present in finitude; he is also present as the triune identity of oneness, equality, and union. ${ }^{14}$

11 E.g., a finite line participates in the indivisibility of an infinite line by not being divisible beyond the point where it no longer is a line; De docta ignorantia I, 17, 47 .

12 Due to the Hegelian influence on twentieth century theology, this conflation of biblical monotheism and the simplicity of apophatic infinity has been heavily contested. For a contemporary defense of a perspective closely related to Cusanus's, see David Bentley Hart, The Beauty of the Infinite: The Aesthetics of Christian Truth (Grand Rapids, MI: W. B. Eerdmans, 2003).

13 De docta ignorantia I, 25, 84.

14 De docta ignorantia I, 7, 10. 
This exploration of Augustinian Trinitarianism as modified by the school of Chartres ${ }^{15}$ may sound abstract and speculative, but the point Cusanus is trying to make is valid, given the idea of infinity as his philosophical point of orientation. Alterity and inequality are basic phenomena in the finite world in the sense that they are presupposed in the investigation of all other phenomena, in other words, things and concepts can only differ by being different. As transparent to infinity, phenomena manifest infinity in two different ways that are each equally transparent to the same infinity. The infinite can thus only be present in the finite through the identity of difference.

With these arguments, Cusanus succeeds in integrating divine oneness and threeness so that, without succumbing to modalism, he avoids the critique leveled against Peter Lombard for emphasizing God's unity to the extent that it acts as a fourth element besides the three persons. ${ }^{16}$ The only consistent alternatives ${ }^{17}$ to the Trinitarian approach Cusanus advocates here are either a severing of the relation between God and the world (resulting either in a sharply dualist or a one-sidedly atheist worldview), or their conflation, leading to idolatry or pantheism. From Cusanus's point of view, these options may be flip sides of the same coin. God may be inexplorable in his infinite inexplicability; in his relation with the world, however, God can only be consistently approached as triune.

Whereas the doctrine of the Trinity presents a non-idolatrous understanding of finite participation in the infinite as a logical necessity, the doctrine of the Incarnation presents it as a temporal reality. As a thought experiment, however, it is possible to develop a Chalcedonian Christology of the hypostatic union of the divine and human in Christ without separation or conflation, and in the beginning of Book III of De docta ignorantia, this is exactly what Cusanus does. ${ }^{18}$ Nevertheless, the Gospel story insists that this hypothetical union is actually realized, ${ }^{19}$ where the full realization of the participation of

15 See Bernard McGinn, The Harvest of Mysticism in Medieval Germany (1300-150o), The Presence of God: A History of Western Christian Mysticism, vol. 4 (New York: Crossroad, 2005), 470-475.

16 See, e.g., Martin Anton Schmidt, "Dogma und Lehre im Abendland II: Die Zeit der Scholastik," in Handbuch der Dogmen- und Theologiegeschichte, ed. Carl Andresen, vol. 1 (Göttingen: Vandenhoeck \& Ruprecht, 1989), 567-754, 6o9-61o.

The question whether the Orthodox approach to the Trinity as origin, birth, and procession is to be considered as an alternative to the modified Augustinian approach maintained by Cusanus, is beyond the scope of the present investigation. Hart, The Beauty of the Infinite, tries to combine them.

18 De docta ignorantia III, $1-3$.

19 De docta ignorantia III, 4. 
finite createdness in infinity is given with the perichoretic unity of God and human in Christ. Accordingly, Book III of De docta ignorantia is an exploration of faith, unfolded with an appropriation of the doctrine of the Incarnation as the key to understanding the relation between God and the world. ${ }^{20}$

The worldview explored in De docta ignorantia is Christian at its core and unlimited in its scope. Cusanus's starting point is the exploration of the philosophical concepts of finitude and infinity. But he insists that the participation of the finite in the infinite (without which the world either falls apart in disparate fragmentation or merges into undifferentiated fuzziness) can only be upheld through strict adherence to the Chalcedonian emphasis on the immutability and inseparability of the two natures of Christ. Here we see an intriguingpossibly even provocative-insistence on the necessity of a Christ-centered exploration of the world, even within a philosophical context. Given Cusanus's basic presuppositions, though, his position can hardly be seen as inconsistent.

\section{Trinitarian Christological Monotheism as Theology of Religion}

How, then, does Cusanus apply his Christologically informed dialectic of finitude and infinity to the problem of religious pluralism? In response to this question, we will see that he does this basically by repeating and extending the approach of De docta ignorantia, seemingly without finding it necessary to undertake any major shifts in the positions maintained within the work.

In De pace fidei, Christian faith is taken for granted as the point of orientation, in the sense that from the outset, the Incarnation is seen as what enables the ordering of human existence toward its divine origin. ${ }^{21}$ The means by which religions can be reduced to a harmonious unity is thus, on the one hand, through an exploration of the extent to which elements from the doctrines of the Trinity and Incarnation can be accepted within the other religions, and on the other hand, through an investigation of how far one can go in accepting the variety of religious rites from the perspective of Christian worship. A number of wise figures from different religions and traditions are therefore summoned to the heavenly throne, in order to discuss and to be instructed in how to realize this inherent unity within the apparent plurality of world religions. ${ }^{22}$

20 For references to literature discussing the centrality of Christology in the thought of Cusanus, see Alfsvåg, What No Mind Has Conceived, 127-128.

21 De pace fidei II, 7.

22 De pace fidei III, 9. 
Monotheism is the obvious presupposition of this approach: All true believers seek the one God, as there is no other to be sought. ${ }^{23}$ The problem of polytheism is therefore the first to be dealt with, and this is easily done, as Cusanus claims that even polytheists maintain the oneness of the concept of deity, common to all deities. ${ }^{24}$ Thus, in the council of the wise (as it is called in the book), both the monotheist Arab Muslim ${ }^{25}$ and the presumably polytheist Indian ${ }^{26}$ accept this solution.

The doctrine of the Trinity presents a larger - though still not insurmountable-hurdle. To address this, Cusanus simply reiterates the doctrine of the Trinity from De docta ignorantia, again emphasizing how the ineffability of divine infinity informs the Trinitarian structure of God's work as Creator, ${ }^{27}$ and presenting Christ as the manifestation of the equality through which God establishes the difference of the world. ${ }^{28}$ Muslim and Jewish critiques of the Trinity are interpreted as the consequence of an obviously misguided idea of a plurality of gods, whereas everyone in the heavenly council agrees that to reject the Trinity as it is here explained would be to isolate God and creation from one another, thus nullifying the idea of divine fecundity and creativity. Understandably, the latter is a position nobody wants to defend. ${ }^{29}$

Having thus established that all the wise have reached a common understanding of the Trinity, ${ }^{30}$ the investigation proceeds to Christology, ${ }^{31}$ and the discussion shifts towards the question of whether one can maintain the idea of human nature participating in God, though without compromising God's oneness. The apostle Peter, who at this point in the discussion is the one representing Cusanus's position, argues that one cannot distinguish between the

23 De pace fidei I, 5 .

24 For a discussion of this argument in the context of Cusanus's thought, see Klaus Kremer, "Die Hinführung (Manducatio) von Polytheisten zum einen, von Juden und Muslimen zum dreienen Gott," in Friede unter die Religionen, 126-159, 127-136.

25 De pace fidei $\mathrm{VI}, 17$.

26 De pace fidei VII, 20.

27 De pace fidei VII, 21. Kremer ("Hinführung von Polytheisten, Juden und Muslimen," 143146) explores how, in spite of this emphasis on unity, the distinction between the persons is sufficiently treated. For a discussion of Cusanus's doctrine of the Trinity in De pace fidei and Cribratio Alkorani and its historical provenance, see also Walter Andreas Euler, Unitas et Pax: Religionsvergleich bei Raimundus Lullus und Nikolaus von Kues (Würzburg: Echter Verlag, 1990), 161-170.

28 De pace fidei VIII, 24.

29 De pace fidei VIII, 24-IX, 26.

$30 \quad$ De pace fidei $\mathrm{X}, 27$.

31 For a discussion of this part of the work, see Euler, Unitas et Pax, 171-183. 
nature of maximally realized wisdom at its source and in its manifestation, and that the Nicene doctrine of consubstantiality must therefore be upheld. ${ }^{32}$ This is a doctrine that even the Muslim Persian accepts can be taught without hurting the doctrine of God's oneness. ${ }^{33}$ The Jews may still disagree, Cusanus admits, but since they are few and unarmed, it does not present much of a problem. ${ }^{34}$ Furthermore, insofar as humans have a hope of immortality, they in fact all presuppose the possibility of a union between the divine and human, since only through participation in divinity can humans be carried across the divide of death. Christ demonstrates the realization of this union through his resurrection, which in reality is presupposed by all who hope for immortality. ${ }^{35}$ Hence, Christology is the fulfillment of the hope of all religions, not their rejection. ${ }^{36}$

32 De pace fidei XII, $37-38$. The idea of having the fisherman from Galilee arguing the finer points of Nicene Christology may strike a modern reader as somewhat counterintuitive. By seeing in Cusanus's Christological argument nothing but "laborious and contrived... convolutions" (Biechler, "Interreligious Dialogue," 277), however, one just declares one's lack of willingness and/or ability to engage with the central elements of Christian thought with anything even remotely close to the seriousness Cusanus brings to the question. As documented in Rudolf Haubst, "Die Wege der christologischen manuductio," in Friede unter den Religionen, 164-191, 172, both the Qur'an and contemporary Muslims may express a view of Christ considerably closer to Cusanus's.

33 De pace fidei XII, 39. By letting a Persian represent Islam here, Cusanus may be thinking of, and speaking to, the alleged Nestorian influence on Mohammad; see Haubst, "Wege der christologischen manuductio," 167-168; Euler, Unitas et Pax, 171. Historically, Mohammad's rejection of Christ's divinity is hardly due to Nestorian influence; as maintained by Siegfried Raeder, Der Islam und das Christentum: Eine historische und theologische Einführung (Neukirchen-Vluyn: Neukirchener, 2001), 28, the tendency toward a kind of Pelagianism among Syrian monks may be a more likely candidate.

34 De pace fidei XII, 41. Cusanus employs here a strangely pragmatic argument that differs substantially from the otherwise very principled discussion in the rest of the book; one may therefore, as Biechler suggests ("Interreligious Dialogue," 278), speak of a certain 'anti-Jewish bias' at work here.

35 De pace fidei XIII. As Euler emphasizes (Unitas et Pax, 175-176), Cusanus defends here the necessity of the incarnation without any reference to the doctrine of original sin.

36 As maintained by Gandillac ("Das Ziel der una religio," 210), Cusanus thus finds the unity of religions in "die Bejahung der Heiligsten Dreifaltigkeit und des erlösenden Selbstopfers des fleischgewordenen Gottlichen Wortes." Euler (Unitas et Pax, 180) emphasizes that this leads to a correlation between Christology and anthropology that may remind a modern reader of the work of Karl Rahner. 
The Muslims represent an additional problem in that they do not accept the death of Christ on the cross. ${ }^{37}$ Cusanus handles this problem in the same way he handles the objection against the doctrine of the Trinity: it is commendable as an expression of respect for Christ's significance, but when Muslims understand that Christ's death on the cross in fact enhances his glory, they will readily accept even the reality of his death. ${ }^{38}$ Furthermore, Cusanus employs allegorical interpretation to solve the fact that Muslims and Jews seem to expect a more sensual and temporal heavenly kingdom than the one expected by Christians; he argues, therefore, that the heavenly maidens of the Qur'an should be understood 'similitudinaliter,' i.e., as parables. ${ }^{39}$

Having thus solved all doctrinal problems to the satisfaction of (almost) all the learned representatives of the different religions, Cusanus finally comes to the issue of the variety of rites. Here he finds inspiration in the New Testament emphasis on unity in spite of differences concerning the practice of the law, ${ }^{40}$ and therefore tries to solve the problem by referring to the doctrine that informs the New Testament approach, namely, Paul's message of justification by faith alone, as founded on the biblical faith in the one God. ${ }^{41}$ Salvation is therefore brought through faith in the divine promise. ${ }^{42}$ This faith is served by various signs, though these signs may change even if what they signify does

37 For an extensive treatment of this problem within the contemporary context, see A. H. Mathias Zahniser, The Mission and Death of Jesus in Islam and Christianity (Maryknoll, N.Y.: Orbis Books, 2008). His main argument is that Jesus' prediction of his death is hardly compatible with his voluntary escape from this destiny; this is an argument that should speak even to Muslims. His approach is thus methodologically quite close to Cusanus's.

38 De pace fidei $\mathrm{XIV}, 47-48$.

39 De pace fidei $\mathrm{XV}, 51$.

40 See Romans 14 and 1 Corinthians 8 and 10.

41 As emphasized, e.g., by Euler (Unitas et Pax, pp. 203-224) and Biechler ("Interreligious Dialogue," 279), Cusanus approaches the problem of religious unity and diversity informed by his Neoplatonic emphasis on oneness, but the close relation he then finds for good reasons between his own approach and that of the Pauline link between monotheism and justification by faith (see Romans 3:30-31) is generally overlooked in the scholarship on Cusanus's theology of religion. Albrecht Peters, "Zum christlichen Menschenbild: Freiheit, Erlösung und Rechtfertigung, Glaube und Werke," in Friede unter die Religionen, 214-242, 227-234, discusses Cusanus's reception of the Pauline doctrine of justification by faith in De pace fidei, but more in the context of his anthropology than in relation to his theology of religion.

"Vis igitur quod sola fides illa iustificet ad perceptionem aeternae vitae?" is the question Paul is asked by his somewhat confused interlocutor, according to De pace fidei, to which his answer is affirmative (XVI, $\left.5^{8}\right)$. 
not. ${ }^{43}$ As an example, Cusanus-still following in Paul's footsteps-refers to the problem of circumcision (cf. Galatians 5:6). This rite does not necessarily lead to salvation, and should therefore be avoided; still, for the sake of peace, the majority may accept the differing practice of a minority, so long as it takes place within the framework of a mutual agreement. ${ }^{44}$

But are there, then, no necessary rites? A cardinal of the Catholic Church cannot be expected to treat the sacraments in quite the same way as Paul treats circumcision, thus Cusanus's answer to this question is clearly affirmative: there are necessary sacraments. Concerning the rites of everyday worship, however, he limits their number to two: Baptism and Eucharist. Admittedly, according to Cusanus it is faith that saves, not the sacrament. ${ }^{45}$ But by not making use of the sacraments, one shows oneself to be lacking in faith. ${ }^{46}$ The sacraments are therefore to be taken seriously, ${ }^{47}$ and his defense of them includes an attempt at making the doctrine of transubstantiation acceptable for a representative of the Bohemian opposition. ${ }^{48}$ Concerning the other sacraments, Cusanus argues that no conformity is necessary, with the exception that monogamous marriage and some form of priesthood are to be upheld. In other matters, all are entitled to maintain their respective ceremonies, as long as faith and peace are served. ${ }^{49}$

Cusanus's attempt at solving the problem of ritual diversity through the doctrine of justification through faith alone gives his reflections in this part of De pace fidei an almost Lutheran flavor. Parts of his discussion thus read

43 "Signa autem mutationem capiunt, non signatum." De pace fidei XVI, 55.

44 De pace fidei XVI, 6o. This is essentially a repetition of Paul's argument in Galatians: Circumcision is acceptable as long as it is not considered necessary.

45 In this respect Cusanus, like Luther a few decades later, just follows Augustine; see Martin Luther, Luther's works, ed. Helmut T. Lehmann and Jaroslav Pelikan, 55 vols. (St. Louis: Concordia, 1958-1967), vol. 32, 17 .

46 "Fides est necessitatis in adultis, qui sine sacramento salvari possunt, quando assequi non poterunt. Ubi vero assequi possent, non possunt dici fideles, qui se tales esse per regenerationis sacramentum [baptismum] ostendere nolunt" (De pace fidei XVII, 62).

Cf. the summary of Cusanus's view in Peter Casarella, "Sacraments," in Introducing Nicholas of Cusa, 347-372, especially 347: "Cusanus's Christ-centered mysticism... highlights rather than ignores their necessity."

48 De pace fidei XVIII, 67-68. It is therefore hardly correct to say that Cusanus in De pace fidei "betrachtet...verehrungswürdige Gebräuche als Nebensache auf dem Gebiete der Sakramente" (Gandillac, "Das Ziel der una religio," 204), or that Cusanus downplays unus cultus for a one-sided emphasis on una fides (Klibansky, according to the discussion recorded on 205 in the same volume). 
as an exposition of article seven in Confessio Augustana. ${ }^{50}$ There are two important differences though. Cusanus's reflections are structured by a dualist reception of the Augustinian res/signum dialectics that Luther, however, rejected; ${ }^{51}$ in this respect, Luther's insistence on the reality of the sacramental manifestation of divine presence arguably maintains the perichoretic emphasis of Chalcedonian Christology more consistently than Cusanus and Augustine's perspectives. On the other hand, there is a breadth of scope in the Cusan approach that leaves all internally Christian applications of the rite problem behind; as there is only one God, all worship service is-willingly or unwillingly — related to him, and has to be evaluated as such. ${ }^{52}$

Cusanus may seem naive in his apparent optimism concerning the universal applicability of a Neoplatonic philosophy of religion and the Pauline doctrine of justification by faith alone, viewing them as closely related aspects of a unified approach to the problem of religious pluralism. After all, religions are not that easily reconciled. But naiveté may not be the appropriate description. Cusanus may well have been aware that De pace fidei could hardly expect immediate approval in all quarters. ${ }^{53}$ It is probably more appropriate to say that he was trying to work out the implications of the basic points of orientation constituting his own worldview. He had already come to the conclusion that one cannot reject the doctrines of Trinity and Incarnation without committing idolatry by destroying the possibility of developing a coherent doctrine of divine creativity. This argument is worked out in detail in De docta ignorantia, while in De pace fidei it is applied in a way that invites the adherents of other

50 "And it is enough for the true unity of the Christian church to agree concerning the teaching of the gospel and the administration of the sacraments. It is not necessary that human traditions, rites, or ceremonies instituted by human beings be alike everywhere"; Robert Kolb and Timothy J. Wengert, eds., The Book of Concord (Minneapolis, MN: Fortress Press, 2000), 43.

51 As far as the word of God and the divinely instituted sacraments are concerned, there is in Luther's view an identity between signum and signatum; see Alfsvåg, What No Mind Has Conceived, 227-228. But even Luther does not identify revelation and Bible to the extent that he questions the translatability of the latter in the way Muslims traditionally have done with the Qur'an (Raeder, Der Islam und das Christentum, 211-212).

$5^{2}$ Luther would, however, basically agree, and one may read his exposition of the first commandment in the Large Catechism (Kolb and Wengert, eds., The Book of Concord, $386-390)$ as an attempt at undertaking just such an evaluation.

53 According to Euler (Unitas et Pax, 223), Cusanus may have thought of this as an eschatological goal. Gandillac ("Das Ziel der una religio") speaks of the utopian character of De pace fidei, carried by a hope for what "vom rein menschlichen Standpunkt aus als unerreichbar gelten muß" (204). 
religions to consider its merits. ${ }^{54}$ Given Cusanus's basic presuppositions, this was probably the only way of doing it.

Thus, there are no major shifts in Cusanus's thinking between De docta ignorantia and De pace fidei; there is a difference of emphasis, but not of content. The argument is expanded, however, in Cusanus's exploration of the relevance of the Pauline argument concerning the link between monotheism and justification by faith. If God, as Cusanus argues in De docta ignorantia, is always present in finite phenomena as the condition of their being perceived as finite phenomena, all finite phenomena can therefore be seen as manifestations of the divine, so long as finitude and divinity are not conflated. Hence, the irreplaceable phenomena explicitly singled out by divine revelation (the sacraments) are respected. Cusanus may thus advocate (to a considerable extent) the possibility of a rituum varietas. However, he unabashedly emphasizes that the one criterion for their evaluation is the existence of the idea of the Creator's presence within creation, which informs the Christian doctrines of Trinity and Incarnation, the absence of which Cusanus views as leading unfailingly to the idolatry of a dualist spirit/matter reductionism. If God is not really present - and how can he be if the possibility of Incarnation is rejected?then all worship degenerates to idolatry. But once the specificity of the sacraments is upheld and the centrality of the doctrines of Trinity and Incarnation is accepted as undisputable, one should then courageously explore the principle of 'religio una in rituum varietate.'

\section{The Inconsistency of Alternative Religiosity as Critique of Islam}

Although De pace fidei is in principle universal in its approach to the problem of religious plurality, the Abrahamic religions are still nevertheless the main frame of reference. Other religious traditions come into view insofar as the problem of polytheism is briefly considered, but beyond that the discussion is limited to problems related to Judaism, Islam, and different Christian tra-

54 This Christological foundation of Cusanus's theology of religion is emphasized also by Euler (Unitas et Pax, 215), whereas in Wolfgang Heinemann, Einheit in Verschiedenheit: Das Konzept eines intellektuellen Religionsfriedens in der Schrift De pace fidei des Nikolaus von Kues (Altenburg: CIs-Verlag, 1987), the author — though clearly aware of it (138) — pays scant attention to it in his analysis of Cusanus's theology of religion, thus coming to the conclusion that Cusanus considers religious pluralism as a necessity both for ontological and epistemological reasons (177-179). 
ditions. Still, the approach is somewhat general in the sense that not much attention is paid to the specific doctrines of the different religions. ${ }^{55}$

This is different, however, in Cusanus's Cribratio Alkorani ("Sifting of the Qur'an"), which, as the title suggests, discusses only the Qur'an, the holy book of the most important alternative to the Christian faith at the time. But it is also not completely different, since Cusanus reads the Qur'an as a book from within the Abrahamic tradition that shows considerable Christian influence in the way it treats the person of Christ and some of the Christian doctrines. Accordingly, Cusanus's objective in Cribratio is to discover the truth of the Gospel in the Qur'an, in spite of the fact that in his view, Mohammad was far removed from a correct understanding of it. ${ }^{56}$ Cusanus does this by showing that the Qur'an maintains some Christian doctrines that are fairly unaltered, while those that criticize and reject other parts of the Christian faith are inconsistent and self-contradictory. One can certainly consider this a far cry from the peaceful approach demonstrated in De pace fidei. ${ }^{57}$ Arguably, however, the main difference is the greater realism of the Cribratio, as Cusanus here actually engages with Muslim theology and does not satisfy himself with lofty affirmations of what all wise members of the heavenly council ought to agree on.

In Cusanus's view, the Qur'an is of course to be commended for its monotheism. ${ }^{58}$ The problem is, however, that the Qur'an understands the Trinity (the view of Christ as the Son of God) and Christ's death on the cross as incompatible with true monotheism. ${ }^{59}$ Cusanus has a nuanced approach in response to these problems. Concerning the Trinity, he repeats the main points from $D e$ docta ignorantia and De pace fidei concerning the close relationship between the doctrines of Trinity and creation. In Cusanus's view, it is impossible to reject the one without rejecting the other, and he remains convinced that he can make this point in a way that should be relevant for Muslims. ${ }^{60}$ Apart from the rationality of the Trinitarian doctrine, Cusanus points to the Qur'an's doctrine of the Spirit of $\mathrm{God}^{61}$ and its esteem for the New Testament (which clearly

55 Cf. Euler, Unitas et Pax, 216: "Die Aussagen zu den dogmatisch-theologischen Gehalten der nichtchristlichen Religionen bleiben in De pace fidei äußerst vage."

56 Cribratio, I, 16: "in Alkorano reperiri evangelii veritatem, licet ipse Mahumetus remotissimus fuit a vero evangelii intellectu."

57 See, e.g., Biechler, "Interreligious Dialogue," 285.

$5^{8}$ Cribratio, I, 2.

59 Cribratio I, 3.

6o Cribratio II, 1-11.

61 Cribratio II, 11, 112. 
has a doctrine of the Trinity) as a holy book ${ }^{62}$ as arguments that should lead Muslims to accept a Trinitarian view of God.

The Qur'an holds Christ in high esteem, considering him a man of God born by the Virgin Mary. Despite the fact that the Quran denies Christ to be the Son of God, Cusanus tries to show that the Qur'an does in fact consider Christ divine by describing him as the word sent from heaven who could perform miracles. ${ }^{63}$ Furthermore, the Qur'an also accepts the Christian view that Christ is still alive.$^{64}$ Hence, Cusanus considers the Muslim rejection of Christ's death on the cross as an example of accommodation, since the Arabs at Mohammad's time would not have been able to reconcile Christ's exalted position with his lowly death on the cross. ${ }^{65}$ Again, basically following the argument of De pace fidei, Cusanus thus seems fairly confident that he can use the Qur'an as a testimony to Christ's divinity.

What, then, is the reason that the Qur'an both rejects and confirms the Trinity, as well as the divinity of Christ? Here Cusanus becomes somewhat more ambiguous, entertaining the view that Mohammad was both misguided ${ }^{66}$ and willingly deceived others to maintain his own position. ${ }^{67}$ The outcome is that his message is unclear; ${ }^{68}$ consequently, Cusanus claims that the Qur'an cannot be considered a book of God. ${ }^{69}$ In some of his critical passages, there-

62 Cribratio II, 11, 114. For a summary of this argument, see Euler, Unitas et Pax, 168.

63 Cribratio I, 12, 59. Cusanus's reference is to Surah 3:45: "O Mary! Lo! Allah giveth thee glad tidings of a word from him, whose name is the Messiah, Jesus, son of Mary, illustrious in the world and the Hereafter, and one of those brought near (unto Allah)"; and to Surah 3:49: "And will make him [Messiah] a messenger unto the Children of Israel, (saying): Lo! I come unto you with a sign from your Lord. Lo! I fashion for you out of clay the likeness of a bird, and I breathe into it and it is a bird, by Allah's leave. I heal him who was born blind, and the leper, and I raise the dead, by Allah's leave." Cusanus used the Latin translations of the Qur'an available to him, whose interpretations of the text are not always confirmed by modern translations. My quotations are taken from Mohammed Marmaduke Pickthall, trans., Holy Qur'an (Hyderabad: Mir Osman Ali Khan, 1976).

64 Cribratio II, 13, 121.

65 Cribratio II, 13, 124. Cusanus does not discuss the New Testament view that this skándalon is a necessary aspect of the Christian message; see 1 Corinthians 1:23.

66 Cribratio I, 1, 23. Cusanus is here following the traditional view that Mohammad was influenced by the Nestorian Sergius; see, e.g., Euler, Unitas et Pax, 157.

67 Cribratio III, 8.

68 Cribratio III, 2, 163; III, 9-10.

69 Cribratio I, 1. Cusanus states this in no ambiguous terms; it cannot be true that the Quran is from God, "cum illa in libro contineantur, quae ob suam turpitudinem iniustitiam et notorietatem mendacii et contradictionis deo sine blasphemia adscribi nequeant" $(\mathrm{I}, 1,22)$. 
fore, Cusanus seems less interested in inviting Muslims into a reasonable dialogue, and instead clearly states what he as a Christian thinks of this book. Thus, it may well be the case that Cusanus is mainly writing to convince Christians who have converted to Islam..$^{70}$ Still, Cusanus generally interprets the Qur'an as a humanist scholar, taking the book seriously as it presents itself, namely, as a religious tract, written from within the Christian tradition to the extent that it refers to the Old and New Testaments, the prophets, and Christ as undisputable religious authorities. And, given his point of departure, Cusanus may very well be right in maintaining that the contradictions and ambiguities of the Quran may be too many to neglect.

As a scholarly work, Cribratio Alkorani does not quite reach the level of De docta ignorantia and De pace fidei. It is somewhat haphazardly organized, and - apart from the obvious fact that it engages with Muslim positions considerably more in detail than the former works-does not really advance the philosophical and theological arguments contained in the other two books. One may even argue that the Cribratio falls behind since it nowhere discusses the rites question. Cusanus does not say why it is left out, but perhaps the more detailed study of the doctrine and practice of Islam had made him doubt the feasibility of his earlier position. Except for the anti-Islamic rhetoric of Cribratio, it is still a work that recommends a peaceful approach to the problem of religious pluralism. It encourages religious leaders to relate to one another by means of argument and discussion, taking care not to let doctrinal differences disappear in a cloud of fuzzy benevolence. Compared to the somewhat high-minded declaration of a Christian-based unity of religions in De pace fidei, it is not at all clear whether this is to be considered a mistake.

\section{Cusanus's Theology of Religion in a Contemporary Perspective}

As demonstrated, Cusanus's understanding of the finite world's relation to the infinite informed his theology of religion. It made for a consistent and fruitful approach through which Cusanus sought to guide his contemporaries away from violence and toward a peaceful dialogue, aiming to establish a common point of reference for all religions without overlooking their obvious differences. A last question, however, remains to be asked: if Cusanus's approach were to be extended into today's debates, where would it take us?

70 This is the view of Biechler, "Interreligious Dialogue," 285. Cusanus explicitly refers to this group in Cribratio I, 3, 28. 
In contemporary scholarship, the discussion concerning the evaluation of the relation between religions is usually structured according to four different models: Christological exclusivism, Christological inclusivism, universalism (also known as pluralism), and parallelism (or incompatibilism). ${ }^{71}$ Of these, universalism is obviously incompatible with Cusanus's position. An understanding of all religions as equally valid approaches toward the Unknowable One is clearly far removed from Cusanus's insistence on Christocentric Trinitarianism as indispensable for any rationally defensible approach to the question of religious pluralism. ${ }^{72}$ The one question to be asked from the Cusan perspective to the universalists is whether they can integrate the distinction between idolatrous and non-idolatrous worship into their approaches with the seriousness that all monotheist religions presuppose. If this question is answered in the negative, it seems quite difficult to avoid the conclusion that religious universalism is misguided..$^{73}$

Furthermore, Christological exclusivism and inclusivism are not necessarily opposites, since the question of how far one should go in looking for confirmation of an incarnational way of thinking within different religious traditions may have a variety of answers. Exactly where on this axis Cusanus should be positioned may well remain an open question. ${ }^{74} \mathrm{He}$ is certainly not a narrow-minded exclusivist, but how far his inclusivism really extends is a difficult question to answer without becoming anachronistic. Today, we know

71 For a summary of these positions, see Alister E. McGrath, Christian Theology: An Introduction (Malden, MA: Blackwell, 2007), 457-463. Christological exclusivism maintains that Christ alone saves; Christological inclusivism agrees, but finds the saving Christ in a variety of religious contexts; pluralism or universalism maintains the basic equality of all religions, while parallelism or incompatibilism rejects the possibility of comparing them.

72 Heinemann, Einheit in Verschiedenheit (cf. note 54 above) reads universalism into Cusanus by systematically ignoring his Christological and Trinitarian emphases. As maintained by Thomas P. McTighe, "Nicholas of Cusa's unity-metaphysics and the formula religio una in rituum varietate," in Nicholas of Cusa In Search of God and Wisdom, ed. Gerald Christianson and Thomas M. Izbicki, (Leiden: E. J. Brill, 1991), 161-172, this would amount to seeing the differing religions as explicationes of the one true religion as their complicatio; this way of thinking, however, is contrary to what is maintained by scholars like Stallmach and Biechler, absent from De pace fidei.

73 According to Clark H. Pinnock, A Wideness in God's Mercy: The Finality of Jesus Christ in a World of Religions (Grand Rapids, Minn.: Zondervan, 1992), 70, universalism is founded on modernity's rejection of the possibility of definite divine presence, which (pace Heinemann) is the very foundation of Cusanus's theology of religion.

74 Euler, Unitas et Pax, 256-258 discusses this problem as "die Differenzierung zwischen exklusiver und inklusiver Absolutheit." 
more about religions and the hermeneutical problems involved in interpreting them, thus the question of what Cusanus's position would have been if he had known as much as we do today rapidly dissolves into speculation and counterfactuality.

The question of the relation between Cusanus's approach and that of incompatibilism remains an intriguing one. It does not allow for a direct answer, as the discussion of incompatibilism has been mostly informed by a discussion of the relationship between Christianity and Buddhism, and as there was hardly any engagement with Buddhism in the West before the nineteenth century, this is something entirely outside Cusanus's horizon. Contemporary Buddhist philosophy of religion, however, has engaged with Cusanus and found his perspective fruitful and interesting. ${ }^{75}$ Before one concludes that the relationship might have been mutual, we have to address how the Cusan emphasis on oneness relates to the possibility of its being manifest in incompatible ways. In spite of Cusanus's emphasis on Christocentric Trinitarianism, he is sufficiently informed by apophaticism to recognize clearly the unknowability of the infinite. Still, in Cusanus's view, a religious or philosophical tradition that does not understand itself as the manifestation of the One cannot even hope to be taken seriously as a credible contender in the quest for truth. ${ }^{76}$ Is this approach at all compatible with the idea of the One being present in multiple and mutually incompatible instantiations? It is one thing to maintain the idea of the unknowability of the infinite; it may, however, be something quite different to entertain the possibility of the multiplicity of its simultaneous and incompatible manifestations.

Yet to relate Cusanus's discussion of religious pluralism to the contemporary debate concerning the theology of religion may unduly limit its relevance. Cusanus insists that the idea of an ineffable infinity is indispensable for the exploration of the world. This issues in an emphasis on the rationality of a Trinitarian theology of creation that may still be relevant for current explorations of the relation between God and the world. Modern scholarly

75 See Roger Corless, "Speaking of the unspeakable: Negation as the way in Nicholas of Cusa and Nágárjuna," Buddhist-Christian Studies 2 (1982): 107-117. There is also some discussion of this perspective in relation to the Kyoto school in Alfsvåg, What No Mind Has Conceived, 268-282.

76 Josef Stallmach, "Einheit der Religion-Friede unter den Religionen," in Friede unter die Religionen, $61-81$ is therefore correct in summarizing Cusanus the following way: "Es gibt eine Grundgestalt von Religion, einen Wesenskern, einen gemeinsamen Grundbestand aller Religionen-weil Gott einer ist" (66, italics in original). Cusanus differs from the universalists, though, by never applying this criterion positively to the differing religions; see McTighe, "Nicholas of Cusa's unity-metaphysics," 166. 
investigations of the world tend to proceed from a presupposition of its alleged independence from any kind of theological framework. From Cusanus's point of view, however, this kind of secularized scientism is philosophically flawed. In his view, the possibility of giving a consistent definition to concepts like difference and unity (which are basic for all kinds of intellectual and scientific endeavors) is lost once the idea of infinity is abandoned and deemed philosophically irrelevant. For Cusanus, scientism is a worldview that should be approached like other inherently religious worldviews. ${ }^{77}$ Moreover, the idea of its absoluteness can only be taken seriously to the extent that it appropriates the idea of the unknowability of the infinite.

On the other hand, much contemporary theology has interpreted the relation between God and the world in a way that tends toward letting the world appear as necessary for God to be God, the doctrine of creation thus becoming more of a logical necessity than a free decision by the eternal One. For example, this perspective has informed much of the (Hegelian) insistence on the identity between the so-called immanent and economic Trinity. ${ }^{78}$ For Cusanus, however, God does not need the world in order to be God, and what he is and is not in his infinite unknowability is not for humans to know or guess. It is an indisputable fact that he has created the world and thus made his eternal Trinity manifest and knowable. But the creational and historical (i.e., economic) aspect of the doctrine of the Trinity is still limited in the sense that it can never totally inform our understanding of God in his immanence; in fact, we do not know anything about God beyond the relation he establishes with us through a decision that is entirely his own. ${ }^{79}$

For Cusanus, the idea that the unfolding of the Trinity in creation and salvation should define God in the core of his divinity would imply a conflation of

77 This does not imply the idea of an evaluation of the results of scientific research according to the standard of received religious Orthodoxy; it is, after all, Cusanus's emphasis of the disproportionality of God and the world that informs his recommendation of experiment and observation that was to become the methodological foundation of modern science. What it does imply is that science, for the sake of its own integrity, is dependent on a theological framework for a consistent understanding of its own epistemological situation. Accordingly, John Henry, "Religion and the Scientific Revolution," in The Cambridge companion to science and religion, ed. Peter Harrison (Cambridge: Cambridge University Press, 2010), 39-58 maintains that this is the world view within which the modern scientific revolution took place.

78 See, e.g., Peter C. Phan, "Systematic Issues in Trinitarian Theology," in The Cambridge Companion to the Trinity, ed. Peter C. Phan (Cambridge: Cambridge University Press, 2011), 13-29, 16-18.

79 On this problem, see Hart, The Beauty of the Infinite, $155^{-167 .}$ 
faith and understanding. From his perspective, all understanding - both scientific and theological - starts with trust in the eternal One as irreplaceable and definitive, as there is no other way for God to remain divine and the world to remain worldly in its transparency for the infinite. This is an approach that might be as critically important today as it was when the cardinal wrote his treatises.

In this context, Islam for Cusanus appears ambiguous. It is informed by Christocentric Trinitarianism to the extent that all central elements of the Christian faith may be found in the Qur'an. But in Cusanus's view, this is partly obscured by the partially misguided attempts at accommodation and selfserving religiosity found in the Quran. The honesty Cusanus shows in pointing this out is certainly to be recommended, since attempts at dialogue that do not take difference and disagreement into account lead nowhere. Whether this particular starting point is the most fruitful one is another question. We should, however, have no problems in recommending it as an alternative to discrimination, violence, and persecution. 


\title{
Reading De pace fidei Christologically: Nicholas of Cusa's Verbum Dialectic of Religious Concordance
}

\author{
Joshua Hollmann
}

In 2007, amidst the often polarizing tone of contemporary political and religious discourse regarding Islam and the West, various Muslim scholars from around the world jointly published A Common Word Between Us and You, an open and pacific letter addressed to Christian religious leaders worldwide. ${ }^{1}$ The preface to the letter proposes that since Muslims and Christians comprise more than half of the world's population, "[w]ithout peace and justice between these two religious communities, there can be no meaningful peace in the world," after which it goes on to emphasize that "the future of the world depends on peace between Muslims and Christians." 2 The letter also observes that the source of this peace is found in the revealed sources of both religions, ${ }^{3}$ for both the sacred texts of Christianity and Islam believe that God is one and affirm that followers of God should love their neighbours as themselves. In a similar vein, upon hearing the news of the fall of Constantinople to the Ottomans in 1453, the philosopher and prelate Nicholas of Cusa composed De pace fidei as a creative prayer for peace and a cogent plea for understanding the common religious concepts of Wisdom and the Word of God. ${ }^{4}$ For Cusanus,

1 The text of the Letter is found in Miroslav Volf, Ghazi bin Muhammad and Melissa Yarrington, eds., A Common Word: Muslims and Christians on Loving God and Neighbor (Grand Rapids, MI: Eerdmans, 2010), 28-50.

2 A Common Word, 28.

3 A Common Word, 28-29.

4 While this event is also referred to as the Ottoman conquest of Constantinople, for Cusanus and his Western Christian contemporaries this ominous occurrence marked more than merely a city's fall, but a full-scale catastrophe filled with foreboding of the impending religious and political conflict now exploding along the eastern front of European Christendom. For a classic overview of the early to mid-fifteenth-century conflict between the Ottoman and Christian powers see Franz Babinger, Mehmed the Conqueror and his Time, ed. William C. Hickman, trans. Ralph Manheim (Princeton, NJ: Bollingen Series XCVI, Princeton University Press, 1978). 
the source of peace between Christians and Muslims is found in the source of the cosmos: the Word and Wisdom of God, which the sacred texts of both Christianity and Islam affirm. ${ }^{5}$

Nicholas of Cusa's religious dialogue De pace fidei unfolds his theological view that the common Word and Wisdom between Christians and Muslims is Christ. In this essay we will consider a sapiential and Christological reading of De pace fidei. By reading De pace fidei through a dialectical Wisdom-Word theological lens, Cusanus's complex Christocentric universal and exclusivist approach to Islam will come into focus. Cusanus transmits the intrinsic tension between the exclusivity and inclusivity of orthodox Christology to address his understanding of the intricate relationship between Christianity and Islam. For Cusanus, the cosmic and incarnate Christ (the Verbum of God) forms the basis of an entire Christian philosophy to such a degree that the more he studies the cosmos, the more he sees Christ as the center of the coincidence of opposites wherein the many rites coincide within one religion. ${ }^{6}$ In order to examine the centrality of Christ in De pace fidei, we will begin with the text itself and first read the dialogue theologically through the locus of the Logos, or the Word of God (Verbum). This close read will then unfold through a contextualization of the Logos-Verbum Christology of De pace fidei within the greater Western Christian tradition. Finally, we will conclude with considering what Cusanus's philosophical and theological conversation on the Word and Wisdom of God might contribute to current dialogues between Christians and Muslims.

5 De pace fidei I, 1; h VII, ed. R. Klibansky and H. Bascour (1959); this edition incorporates Klibansky and Bascour's earlier edition, Nicolai de Cusa De Pace Fidei cum Epistula ad Ioannem de Segobia, Medieval and Renaissance Studies Supplement III (London: Warburg Institute, 1956), 1-90. James E. Biechler and H. Lawrence Bond reproduce the Latin text of $\mathrm{h}$ with an English translation in Nicholas of Cusa on Interreligious Harmony: Text, Concordance and Translation of De Pace Fidei (Lewiston, NY: Edwin Mellen Press, 1990). Unless otherwise noted, I shall cite Biechler and Bond for De pace fidei's Latin text and English translation by chapter and paragraph number. Cribratio Alkorani (h VIII), alius prologus 15-16; I, 6, 42; I, 12, 58; I, 14; De pace fidei VI, 16; IX, 26; X, 27; XIX, 68.

6 F. Edward Cranz, "Saint Augustine and Nicholas of Cusa in the Tradition of Western Christian Thought," Speculum 28 (1953): 297-315, especially p. 298. Reprinted in Cranz, Nicholas of Cusa and the Renaissance, ed. Thomas M. Izbicki and Gerald Christianson (Aldershot: Variorum, 2000), 31-40. 


\section{Reading the Word and Wisdom of God in De pace fidei}

In 1446 Cusanus wrote a brief and bizarre treatise on the end of the world: Coniectura de ultimis diebus. ${ }^{7}$ In the work, Cusanus surmises that the world will end sometime between 1700 and $1734 .{ }^{8}$ While today this seems eccentric, in the context of the fifteenth century, conjectures on the ensuing apocalypse were far from strange. Cusanus's predictions are patterned on Augustine's eight epochs found in the conclusion of the City of God and the pervasive apocalyptic speculation of Joachim of Fiore. ${ }^{9}$ Fears of the impending end of the world would continue well after Cusanus with the likes of the Dominican Savonarola and the magisterial reformer Martin Luther, who was often depicted in his time as the prophetic second Elijah sent to proclaim the return of Christ. ${ }^{10}$ Cusanus also believed he lived in the latter days. Thus, in a letter to Jacob von Sirck from October 1453, after the fall of Constantinople, Cusanus writes: "I fear greatly that this violence may defeat us, for I see no possible uniting in resistance. I believe that we must address ourselves to God alone, though He will not hear us sinners."11 In De pace fidei, Cusanus claims that his prayer, at least mystically and metaphysically, has been answered. ${ }^{12}$

What is worth noting is not the conjectured end of the world, but rather, why Cusanus even forges ahead with his speculation. After all, Jesus of Nazareth had warned that no one knows the hour of his coming, which implied the condemnation of those vain seers who attempted to wrest knowledge of the future away from God. ${ }^{13}$ According to Cusanus, however, one may only endeavor to know in this lifetime the incomprehensible truth, even though in this world

Coniectura de ultimis diebus, in the Heidleberg Academy's edition, Nicolai de Cusa opera omnia, vol. IV, Opuscula I, ed. P. Wilpert (1959) (Hamburg: Felix Meiner Verlag, 1932ff.). Hereafter this edition will be cited as "h" followed by volume number. Coniectura de ultimis diebus, 127.

9 Augustine, De civitate Dei XXII, 30. On Joachim and Savanarola, see Bernard McGinn, trans., Apocalyptic Spirituality: Treatises and Letters of Lactantius, Adso of Montier-en-Der, Joachim of Fiore, the Franciscan Spirituals, Savonarola (New York: Paulist Press, 1979). On Luther as Elijah of the last times, see Andrew Cunningham, Andrew Ole, and Peter Grell, eds., The Four Horsemen of the Apocalypse: Religion, War, Famine and Death in Reformation Europe (Cambridge, uk: Cambridge University Press, 2000), 23-25. History 9 (1983): 227-236.

11 Quoted in Karl Jaspers, Anselm and Nicholas of Cusa, ed. Hannah Arendt, trans. Ralph Manheim (New York: Harvest, 1966), 170.

12 De pace fidei I, 1.

13 Mark 13:32; Matthew 24:36. 
of conjectures, and echoing Augustine, we only know incomprehensible truth through symbolism that is infinitely distant from the truth itself. ${ }^{14}$ Or, as he says in his Apologia doctae ignorantiae, true theology remains hidden in sacred Scripture, the very Word of God..$^{15}$ Therefore, Cusanus argues that he speculates because he claims to know only this Word of God, namely, the preincarnate Logos and the person of Christ. ${ }^{16}$ According to the dialogical structure of Cusanus's tract on religious concordance, De pace fidei, it is in Christ that the metaphysical and the physical coincide. According to Cusanus, concordance is the principle by which there is harmony between the one and the many. ${ }^{17}$ De pace fidei identifies the Word of God as Logos and the incarnate interlocutor between the one (God) and the many (representatives of the religion of the world)..$^{18}$ Indeed, for Cusanus, Christ is the very wisdom of God. ${ }^{19}$ Therefore, this Divine Word-Wisdom is the ground for speculating about time and eternity, as well as the basis and starting point for his conciliatory and complicated approach to Islam in De pace fidei and Cribratio Alkorani. ${ }^{20}$ Furthermore, according to Cusanus, every human assertion on what is true is conjecture, yet when connected to Christ - the hypostatic union of God-Man, the infinite and finite, the very way and truth - these conjectures become closer to hidden wisdom. ${ }^{21}$ In De pace fidei and the prologue to the Cribratio Alkorani, this truth is none other than the Word and Wisdom of God, in whom all things are unfolded and from whom they are enfolded. ${ }^{22}$

In De pace fidei, Cusanus identifies Wisdom as the pre-incarnate Logos and the incarnate Christ through whom all things are unfolded and enfolded, and thereby knowable. ${ }^{23}$ Wisdom is therefore made known in the Word of God (Verbum). This Wisdom may be read in the reasonable order and symmetry of creation. ${ }^{24}$ In addition, this Wisdom became incarnate in Christ, who further and supremely reveals the concordance of 'religio una in rituum varietate. ${ }^{25}$ Thus, in the Logos and in Christ, this Wisdom is recognizable and attainable

14 Coniectura de ultimis diebus, 123. Cf., De pace fidei XVI, 55; Augustine, De doctrina Christiana, I, 4-5.

15 Apologia doctae ignorantiae (h II), 4.

16 Coniectura de ultimis diebus, 124.

17 De concordantia catholica (h XIV) I, 1, 4.

18 De pace fidei III, 8; IV, 10; X, 27.

19 Coniectura de ultimis diebus, 124; 1 Corinthians 2:2; Colossians 2:3.

20 De pace fidei III, 9; Cribratio Alkorani prologus, 8-10.

21 De Coniecturis (h III) I, prologus; De pace fidei II, 7; John 14:6.

22 De pace fidei II, 7; III, 8; Cribratio Alkorani prologus, 8-10; Idiota de sapientia (h V) I, 21-23.

23 De pace fidei II, 7; VI, 17.

24 De pace fidei IX, 26.

25 De pace fidei I, 6. 
by Divine illumination, by grace. In De pace fidei, after Cusanus proposes that there remains an infinite gap between human and divine wisdom, he goes on to discuss how there is only one Christ, "in whom human nature is united with the divine nature in supposited unity."26 In Christ, the divine intellect is united to the human intellect. However, in order to reassure Muslims, Cusanus affirms that in this union the unity of God is preserved. For Cusanus, not only are the Divine and human intellects united in the Word, but De pace fide $i$ also holds that human nature is united with the divine nature in the incarnate Christ. He is, as Cusanus writes, "the face of all peoples and the highest Messiah and Christ, as the Arabs and Jews call Christ."27 As the face of all peoples, Christ's face is especially turned toward the great prophets of the 'religio una in rituum varietate. ${ }^{28}$ As demonstrated in the preface to Cusanus's exposition on the Qur'an, the Cribratio Alkorani, this includes the Prophet Mohammed ${ }^{29}$ De pace fidei proposes a global Pentecost - a reversal of the confusion of Babelthat entails the dialectical concordance of discordant religious languages in the one Word of God. The Wisdom and the Word, words and the Word, signs and that which is signified in everything: for the Word and Wisdom of God, according to Cusanus, flows through all ranks of being, and encompasses all things. ${ }^{30}$

Cusanus's dialogue proper of De pace fidei begins with the Wisdom of God, which leads straightaway to the synonymous Word of God. From there, the complexities of unity and plurality and Trinity in unity are discussed, followed by an exposition of the tension between finite and infinite in the incarnation of the Word of God. Finally, resurrection, paradise, faith, tradition, and rites are explored. Together, these propositions or 'storeys,' from natural reason to divine revelation, further expand one by one the foundational element or building block of 'religio una in rituum varietate. ${ }^{31}$ What joins these levels of understanding together with peace is the Wisdom or Word of God. For it is the Word (Verbum) of God who builds, initiates, furthers, clarifies, and finally ratifies the religious discussion. It is, after all, the Word's house of religious peace. Sapientia is unique and through it the cosmos came to be. ${ }^{32}$ Furthermore, towards the beginning of De pace fidei, sapientia is clearly identified as the

\footnotetext{
26 De pace fidei XII, 39; trans. Biechler and Bond, p. 37.

27 De pace fidei XIII, 43: "in illo scilicet qui est facies omnium gentium et altissimus Messias est Christus, prout nominant Christum Arabes et Iudaei"; trans. Biechler and Bond, p. 40.

28 De pace fidei I, 6.

29 De pace fidei I, 6; Cribratio Alkorani, alius prologus, 13-15.

$30 \quad$ De pace fidei II, 7; De concordantia catholica I, 2, 10.

31 De pace fidei I, 6.

32 De pace fidei IV, 11: "Non potest esse nisi una sapientia."
} 
eternal and generating Word of God. ${ }^{33}$ And the cosmos is, after all —at least for Cusanus and his western Christian forbears and contemporaries- the created domain of the Word and Wisdom of God. ${ }^{34}$ Ultimately, the Cusan thesis 'religio una in rituum varietate' flows from the Wisdom and Word of God, and moves dialectically and hierarchically through the cosmos. ${ }^{35}$

According to Cusanus and his medieval predecessors, the world is created in Wisdom, by Wisdom, and for Wisdom. For Christians, this powerful Wisdom of God is further identified with the person and work of Jesus Christ (who, according to orthodox Christian doctrine, is in his twofold nature both Creator and creature). ${ }^{36}$ Thus, the cosmos is rational, and can (and should) be 'read' by the senses and deciphered in the mind and in the harmonious pursuit of being made wise unto the peace of faith. ${ }^{37}$ Cusanus posits that Divine Wisdom may be 'read' in the mind, although owing to the ignorance of sin, it is difficult although not impossible to decipher. ${ }^{38}$ As Book I of De docta ignorantia shows, the cosmos may be read in geometry and mathematics. It may also be read in

33 De pace fidei V, 15: Sapientia igitur est aeternitas"; De pace fidei VI, 17: the Arab (as one well acquainted with wisdom in the Arab philosophical tradition) addresses the Word (Verbum), "Tu es sapientia, quia Verbum Dei."

34 Cf., Augustine, Confessions, XII, xi; XII, xix. Augustine seeks the eternal house of God in the heavens of heavens. This house does not experience the vicissitudes of time. It is the abode of peace and harmony, the goal of the pilgrim. In De pace fidei, Cusanus sets his council in the heaven of reason and the court of God (i.e., the house of reason and house or domos of God, the place of religious peace and the goal of the pilgrim still struggling in a world torn apart by religious violence). In this heavenly house, the 'Trinity' of memory, understanding, and will is one (Cf., Augustine, De Trinitate $\mathrm{X}$, iv). For the religious representatives of the world become one in peaceful accord (not only with each other, but also with angels and the Word of God and the saints). They understand 'religio una in rituum varietate' and remember what has transpired in the heaven or altitude of reason within (the mind's road to God) in order to will it to become reality in the world without (senses) and below (earth). Their actions resemble and participate in the Trinity (by the economy of the Wisdom and Word of God) in memory, understanding, will, and the concord of God's undivided peace.

De pace fidei I, 6.

$36 \quad 1$ Corinthians 1:24.

37 Cf., 2 Timothy 3:15. For Cusanus and St. Paul, Christ, the ultimate Word and Wisdom to whom Scripture testifies, makes seekers of truth and concord wise unto the peace of reconciliation with God and one another, and, hence, harmony between heaven and earth.

38 De pace fidei I, 3: "excitatus admiratione eorum quae sensu attingit, posit aliquando ad te omnium creatorem oculos mentis attollere et tibe caritate summa reuniri, et sic demum ad ortum suum cum fructu redire." De pace fidei I, 4: "Ex quo factum est, quod pauci ex omnibus tantum otii habent, ut propria utentes arbitrii libertate ad sui notitiam pergere queant." Cf., Aquinas, Summa Theologice, Ia, 1, 1: "Quia veritas de Deo per rationem 
Holy Scripture and in the Qur'an. ${ }^{39}$ As De pace fidei illustrates, it may also be read in the writings of the ancient Hellenic philosophers. ${ }^{40}$ The ultimate way in which God makes his Wisdom and the way to happiness and immortality known is through the Incarnation of the Word made flesh - the Word beyond words, the sure via of knowledge, beatitude, and peace. ${ }^{41}$ Thus, in De pace fidei, drastic times (such as the fall of Constantinople) call for drastic measures: the Word and Wisdom of God reason face-to-face with the religious leaders of the world in order to establish an enduring peace of faith..$^{42}$ To realize this peace and avert the maelstrom of religious violence, Wisdom and the Word make opposites known (the many rites and the many adherents of those rites) in relation to the One (both one God and the one religion).

At the outset of De pace fidei, Cusanus identifies truth as the Word of God in which all things are enfolded (complicantur) and through which all things are unfolded (explicantur). ${ }^{43}$ This Truth, this Word and Wisdom, speaks words of truth and wisdom, which in turn reveal-point by point in an unfolding manner - the concordance of one single religion in a variety of rites. Cusanus affirms that "between 'contracted wisdom,' i.e., human wisdom, and wisdom per se, which is divine and maximum and infinite, there always remains infinite distance." 44 Thereby, in this confusing world of conjectures and similitudes, Cusanus's conception of the incarnate Word in De pace fidei utters in dialogical form the path to the signified one religion by means of a variety of signs. ${ }^{45}$ For Cusanus, the human nature of Christ united to the Divine Word leads the imagined wise readers of De pace fidei to the final happiness of religious concord. Cusanus's hermeneutic of Wisdom and the Word through signs and things signified as flowing from and returning to the Word of God as

investigata a paucis, et per longum tempus, et cum admixtione multorum errorum homini proveniret."

39 Cribratio Alkorani, alius prologus, 16.

40 De pace fidei XIX, 68.

41 De pace fidei II, 7; De pace fidei XIV, 49.

42 De pace fidei III, 8: "indiget humana natura crebra visitatione, ut fallaciae quae plurimum sunt circa Verbum tuum extirpentur et sic veritas continue elucescat."

43 De pace fidei II, 7: "Quae quidem veritas intellectum pascens non est nisi Verbum ipsum, in quo complicantur omnia et per quod omnia explicantur."

44 De pace fidei XII, 36 ; trans. Biechler and Bond, p. 36 .

45 De pace fidei II, 7. The Verbum has put on human nature so that humans may attain to the truth of one religion in the variety of rites and eternal felicity: "[Verbum] et quod humanam induit naturam, ut quilibet homo secundum electionem liberi arbitrii in sua humana natura, in homine illo qui et Verbum, immortale veritatis pabulum se assequi posse non dubitaret." Cf., De pace fidei III, 8; De coniecturis I, 2. 
dialogical dialectic of peace. ${ }^{46}$ This Word speaks words in the dialogue form of De pace fidei, and enlightens Cusanus to write words of religious concordance. As his Idiota de sapientia et de mente and De veneratione sapientiae reveal, the master of learned ignorance spent his scholarly and spiritual life searching for the Wisdom and "the peace of God, which surpasses all understanding."47 According to Cusanus, the mysterious and cosmically generating Wisdom cries out in the streets to be welcomed readily by laymen (idiota) and even by the proponent of 'the barbarous ineptitudes' of learned ignorance-Cusanus himself. ${ }^{48}$ And yet, this wisdom leads to greater insight: the final vision of God, whereupon "God grants that He be made visible to us without enigma." ${ }^{49}$

\section{Reading the Christology of De pace fidei within the Christian Tradition}

Cusanus spent his life hunting for this known-yet unknown-wisdom. As Karl Jaspers notes, Cusanus is the only major thinker of his century who did not belong to any school or found a school..$^{50} \mathrm{He}$ was somewhat of a metaphysical loner, much like the great scholars of the ninth century, such as John Scotus Eriugena. And yet, his ideas still remain and he sometimes seems strangely at home in our multi-religious age. His individual quest for the plenitude of wisdom uncovers a new Christocentric and communal understanding of religious peace. Cusanus's Christocentric ideas on religious peace in De pace fidei are deeply rooted in ancient Hellenic thought and the Bible-wisdom as found in both reason and revelation. The Christology of De pace fidei is Johannine. Indeed, for Cusanus as for the author of the Gospel according to John, there is nothing beyond the horizon of the Word (Logos-Verbum)..$^{51}$ Cusanus's cosmic Christology of De pace fidei also transmits the tradition of ancient Hebraic wisdom from the Book of Proverbs, as well as the Hellenic Lady Philosophy

46 Augustine, De doctrina Christiana, I, 4-10. Cf., Hans-Georg Gadamer, Truth and Method, trans. Joel Weinsheimer and Donald G. Marshall, 2nd ed. (London: Continuum, 2004), $435-436$.

47 Philippians $4: 7$ NRSV.

48 Proverbs 8-9; De docta ignorantia, prologus; trans. Biechler and Bond, 87.

49 Idiota de sapientia (h V) II, 47: "sine quo in hoc mundo Dei visio esse nequit, quousque concesserit Deus, ut absque aenigmate nobis visibilis reddatur"; translation in Nicholas of Cusa, The Layman on Wisdom and the Mind, trans. M. L. Führer (Ottawa: Dovehouse, 1989), 49 .

$50 \quad$ Jaspers, Anselm and Nicholas of Cusa, 164.

$5^{1} \quad$ John 1:1-18; De pace fidei II, 7 . 
of Boethius's Consolation..$^{2}$ As in the Gospel of John, there are two dialectical aspects to Cusanus's Christological approach to Islam: universalism and exclusivism. ${ }^{53}$ As a late-medieval churchman, Cusanus inherited both the universalist and exclusivist Christologies of the ecumenical councils of Nicaea (325) and Chalcedon (451). The former included the fundamental tenet of orthodox Christian faith that the Logos is the same substance as God (homoousios, unius substantiae cum patre), through whom all things came to be, while the latter incorporated Pope Leo's famous Tome, which stated that the incarnate Logos, the Son of God, is one person with two natures (divine and human, 'unitatem personae in utraque natura'). ${ }^{54}$ Leo's Tome, serving as prolegomena to the Cribratio Alkorani, weaves together the two threads of universality and exclusivity into the one tapestry of Christ. For these purposes, Leo quotes Proverbs and the Gospel of John: "As Wisdom built a house for herself, the Word was made flesh and dwelt among us." This Word becomes flesh so that the proper character of both natures can be maintained while coming together in a single person..$^{55}$

While Cusanus's sapiential ideas of religious concordance are rooted in reason and revelation, in conciliar and constructive thought, they are also formulated within the catholic historical theological tradition. Another angle for viewing Cusanus's dialectic of reason and revelation, the exclusivity and universality of his Christology as evidenced in De pace fidei, sees Cusanus inheriting both the catholic exclusivity as represented by the late medieval reading of the third-century bishop Cyprian of Carthage, as well as the mystical inclusivity of an Augustian conception of religion. It was Cyprian who famously

52 Proverbs 8-9; Boethius, Consolation of Philosophy I, 1.

53 John 1:1-18; 14:6. On universalist Verbum Christology, see De pace fidei VI, 17-18. On exclusivist Christology, see De pace fidei XI, 30-35.

54 Leo's Tome is a famous letter sent by Pope Leo I, 'the Great,' to the Council of Chalcedon (451) on Christology. It is generally accepted as classic formulation of Christian orthodoxy on the person of Christ. Cribratio Alkorani, preface 1. Council of Nicea, Expositio fidei CCCXVIII partum in Norman P. Tanner, ed., Decrees of the Ecumenical Councils, 2 vols. (London: Sheed \& Ward, 1990), vol. 1, 5. Leo's Tome, Epistula Papae Leonis in Tanner, Decrees of the Ecumenical Councils, vol. 1, 80.

Cribratio Alkorani, preface 1, citing Pio Secundo Universalis Christianorum Ecclesiae Summo Sactissimoque Pontifici. Leo's Tome in Tanner, Decrees, vol. 1, 78: "Fecuditatem virginis spiritus sanctus dedit, veritas autem corporis sumpta de corpore est, est aedificante sibi sapientia domum verbum caro factum est habitavit in nobis, noc est in ea carne quam sumpsit ex homine et quam spiritu vitae rationalis antimavit. Salva igitur proprietate utriusque naturae et in unam coeunte personam." Cf., Proverbs 9:1; John 1:14. 
stated: "Outside the church, there is no salvation (extra ecclesiam nulla salus)."56 Cyprian, much like Cusanus, was adamant in maintaining the unity of the catholic church, especially in the face of heresies and schisms threatening to rend concordance asunder. Thus, Cusanus appeals to a late medieval reading of Cyprian. According to Cusanus, the source of this unity is Christ, as represented on earth by the bishops and preeminently the Bishop of Rome. ${ }^{57}$ In $D e$ concordantia catholica, Cusanus notes that from ancient tradition there is only one cathedra and one rule established in hierarchical gradations. ${ }^{58}$ Similarly, Cyprian had asked rhetorically: "If a man does not hold fast to this oneness of the Church, does he imagine that he still holds the faith?"59 The precursor to the Cribratio Alkorani, turning us back again to Leo's Tome, is evidence that Cusanus considers Islam to be an ancient Nestorian heresy now continued as a sect. In De pace fidei, moreover, Cusanus conceives that schisms exist because many longstanding customs confuse rites for religion and eventually become lost in the diffuse manifestations of the one unity of religion. ${ }^{60}$ Therefore, the goal of De pace fidei is the eradication of global religious schism through conciliar and Christocentric dialogue. Furthermore, for Cyprian and Cusanus, "the Church forms a unity, however far she spreads and multiplies by the progeny of her fecundity." 61 And, for Cyprian, "[y]ou cannot have God for your Father

$5^{6}$ Cyprian of Carthage, Epistle LXXII, Ad Jubajanum de haereticis baptizandis, section 21: "Salus extra ecclesiam non est." See also how Cyprian is quoted by Pope Boniface VIII in the high water mark of the medieval papacy, Unam sanctam (1302).

57 Cyprian, De Ecclesiae catholicae unitate, 4-6. On the primacy of the Roman chair, see 4 (first edition of the treatise, note the two versions of the treatise on this pivotal section): "Super illum aedificat ecclesiam et illi pascendas oves mandat et, quamvis apostolis omnibus parem tribuat potestatemm unam tamen cathedram constituit et unitatis originem adque rationem sua auctoritate disposuit. Hoc erant utique et ceteri quod fuit Petrus, sed primatus Petro datur et una ecclesia et cathedra una monstratur."

$5^{8}$ De concordantia catholica I, VI, 36 : "Unde sicut episcopatus unus, ita una cathedra et una praesidentia gradualiter et hierarchiæ constituta."

59 Cyprian, De Ecclesiae catholicae unitate, 4 (2nd edition of the treatise): "Hanc ecclesiae unitatem qui non tenet, tenere se fidem credit?" For an English translation of the above, see Cyprian, De Lapsis and De Ecclesiae Catholicae Unitate, text and trans. Maurice Bévenot (London: Oxford University Press, 1971), 64-65.

6 De pace fidei I, 4 .

61 Cyprian, De Ecclesiae Catholicae Unitate, 5 (2nd edition of the treatise); trans. Bévenot, 65 : "Ecclesia una est quae in multitudinem latius incremento fecunditatis extenditur." Cf., $D e$ concordantia catholica I, I, 7; I, VI, 35; I, VIII, 43; I, XIV, 58; XV, 60; II, XVII, 141; II, XXVI, 209; II, XXXIV, 256. Consider also the global scope of the church or one religion in the variety of rites in De pace fidei. 
if you no longer have the Church for your mother."62 In the pivotal and foundational beginning of De concordantia catholica, on the Word of God, Cusanus cites this very same passage of Cyprian. ${ }^{63}$ There he writes that "concordance is highest truth itself," and after citing Cyprian, describes how those in the church are united to Christ. ${ }^{64}$ Accordingly, Cusanus writes:

Christ is the way, the truth, and the life, and the head of all creatures, the husband or spouse of the church, which is constituted in a concordance of all rational creatures - with him as the One, and among themselves, the many—in various [hierarchical] gradations. ${ }^{65}$

Cusanus, like Cyprian before him, clearly connects the unity of the church to the person of Christ. Yet, in a distinctly innovative turn, he moves beyond the confines of the catholic church in De pace fidei to include Judaism, Islam, and Hinduism, through a hierarchical gradation of one religion in the variety of rites. These religious rites are coincidently and consubstantially joined as one concordance of peace through the dialogical Verbum and by way of his hierarchical emissaries, most notably, the apostle and first pope, Peter. ${ }^{66}$ According to Cusanus, it is the Verbum of God that reveals the religious concordance of one religion in the variety of rites dialectically, one theological proposition after another, until the conversation continues onto the crucial intricacies of Christology with Peter, who takes his turn in the dialogue of De pace fidei after Christ, "the eternal pontiff." 67

The Christology of De pace fidei is exclusive in its appeal to ancient formularies of Christian thought, but it is also inclusive and universal in its conception of religious concordance through the Word of God. Cusanus brings

62 Cyprian, De Ecclesiae Catholicae Unitate 6; trans. Bévenot, 66: "Habere iam non potest Deum patrem qui ecclesiam non habet matrem." Cf., De concordantia catholica I, I, 7 . Cited by Cusanus in the context of arguing for the primacy of I, VI, 35 .

63 De concordantia catholica I, I, 7.

64 De concordantia catholica I, I, 7.

65 De concordantia catholica I, I, 8; Paul E. Sigmund, trans., The Catholic Concordance (Cambridge: Cambridge University Press, 2003), 7. Cf., John 14:6. "Unde haec est summa dicendorum, quod Christus est via, veritas et vita et omnium creaturarum caput, maritus sive sponsus ecclesiae, llquaell per concordantiam creaturarum omnium rationabilium ad eum unum et inter se plurium constituitur secundum varias graduationes."

66 Peter leads the conversation of De pace fidei on Christology proper from chapters XI to XVI. Cf. Mark 8:29 where Christ asks Peter, "But who do you say that I am?" (NRSv). The question of who Christ is in De pace fidei is answered by Peter.

67 De concordantia catholica I, III, 13; trans. Sigmund, Catholic Concordance, 11. 
Neoplatonic philosophy into the service of catholic truth. For Cusanus, the hypostatic Word of God has its own exclusive substantial reality (contra modalism), and the Word universally flows through all things. Yet in De pace fidei, Cusanus aims to hold the universal and the exclusive together in his Christocentric approach to Islam. According to the prologue to the dialogue, through the art of contemplation he sees all this as the complete metaphysic of religious peace. God reveals the truth of one religion in the variety of rites. To echo Anselm of Canterbury, Cusanus sees and believes in order to understand the religious concordance of the Word of God. ${ }^{68}$ For Cusanus, Athens coincides with Jerusalem, in other words, the City of God as reason coincides with revelation to form one universal metaphysic of unity. Unlike Tertullian, however, Athens has everything to do with Jerusalem. ${ }^{69}$ Thus the dialogue begins in a metaphorical Athens, as signified by the Greek interlocutor, and concludes in the heavenly and earthly Jerusalem, where the unity of the peace of faith is pronounced as concurrent with ancient philosophy and Christian theology as one complete religious metaphysic. ${ }^{70}$

In De pace fidei, Cusanus dialectically and hierarchically holds together Athens and Jerusalem, reason and revelation, universalist and exclusivist outlooks, conciliar-catholic tradition and the pragmatic concerns of the present, all of which are centered in the cosmic and incarnate Christ. ${ }^{71}$ Another way of reviewing the two aspects of the universalist and exclusivist polarities of Cusanus's Christology focuses on his love of cataphatic and apophatic theology (as the master of learned ignorance). Cusanus begins the theological dialogue of De pace fidei with the Word as Truth and Wisdom, which embraces all things and is embraced by the philosophers. ${ }^{72}$ What humanity can say about God arises, then, (to allude to Dionysius the Areopagite) from the sum total of creation, but also, more precisely, from the sum total of religious rites. Cusanus believed that Wisdom made the world. Therefore, this cosmos is rationally knowable by all those seeking truth. Yet for Cusanus, all human assertions are but conjectures. Thus, the revelation of Wisdom made flesh is required in order to clarify confusions of rites with religion, or creation with the creator.

68 Anselm of Canterbury, Proslogion I, 1.

69 Tertullian, Prescription of the Heretics, 7.

70 De pace fidei IV; XIX, 68. On the primacy of Jerusalem as city of ecclesiastical and hierarchical synthesis, see De concordantia catholica XVI, 64 .

71 For a succinct overview of the universalist and exclusivist impulses of Christology, see Richard Viladesau and Mark Massa, eds., World Religions: A Sourcebook for Students of Christian Theology (New York: Paulist Press, 1994), 9-16.

72 De pace fidei II, 7; IV-VI. 
Cataphatic verbosity may lend itself to catastrophic confusion of words for the Word. The names for God "are fittingly derived from the sum total of creation,"73 and indeed, according to Dionysius, theologians praise God "by every nameand as the Nameless One."74 Thus, since God created all things, everything shares in beauty and is good. ${ }^{75}$

Dionysius's hierarch, the Word of God, appears as the central character of Cusanus's religious dialogue and as the foundation of his conception of one religion in the variety of rites. ${ }^{76}$ We therefore see a Dionysian, cataphatic (universalist) side to Christology: the Word embraces all things. Even so, this Word speaks for the hidden God who remains ever unknown and unknowable. ${ }^{77}$ Within this cataphatic sum total of creation, some rites are better than others, and some theological, dialogical points are higher than others. According to Dionysius and Aquinas, hierarchy operates from the lower to the higher by way of the middle-according to the so-called 'lex divinitatis. ${ }^{78}$ As Dionysius maintains, theologians discuss hierarchies in order to make known the ranks of heaven, but also to reveal the mystery of God. ${ }^{79}$ Thus, "[ $\left.t\right]$ he most evident idea in Christian theology, namely, the sacred Incarnation of Jesus for our sakes, is something which cannot be enclosed in words nor grasped by any mind." ${ }^{80}$ What can be grasped with more certainty is that Christology and the sacred incarnation of the preexistent Logos come to the fore in Cusanus's conversation with Islam. Moreover this Christological approach to Islam in De pace fidei is not only conciliar and catholic, but also hierarchical and dialectical. Christ mediates between the lower to the higher, between discursive rites and speculative religious concordance. The angels receive the truth of one religion in the variety of rites through intellectual purity, while humanity receives it by means of sensible signs. ${ }^{81}$ It is the Word, moreover, that mediates this

73 De divinis nominibus I, 7, 597A, p. 56. Translation by Colm Luibheid, Pseudo-Dionysius: The Complete Works (New York: Paulist Press, 1987). Cf., De pace fidei VII, 21: "Nam nomina quae Deo attribuuntur, sumuntur a creaturis, cum ipse sit in se ineffabilis et super omne quod nominari aut dici posset."

74 De divinis nominibus I, 6, 596A, p. 54; trans. Luibheid.

75 De coelesti hierarchia II, $3,141 \mathrm{C}$.

$7^{6}$ De ecclesiatica hierarchia II, 1, 393A.

77 De pace fidei I, 4-5; II, 7 .

78 Ephesians 1:20-21; De coelesti hierarchia III, 1, 164D; Pope Boniface VIII, Unam sanctam; Aquinas, Summa Theologice Ia., 108, 1; Summa Theologice Ia., 108, 6.

79 De coelesti hierarchia II, 5, 144C.

8 o De divinis nominibus II, 9, 648A, p. 65; trans. Luibheid.

81 De coelesti hierarchia I, 1-3, 120B-124A; Aquinas, Summa Theologice Ia, 108, 1; De pace fidei I, 2 ; XVI, 55 . 
concordance from the angels (higher) to humanity (lower). The dialogue proper of De pace fidei begins more generally (with concepts such as Divine Wisdom and Word), and then by the end of the imagined conversation moves to touch upon all forms of diverse rites and practices. Yet the dialogue concludes with the stillness of peace, which surpasses all human power of utterance. Final realization of religious peace remains mystical and speculative, beyond this world, the theoria of vision, and is envisioned in the dialogue to be the New Jerusalem. The dialogue is bookended as Cusanus's own recollection of an intellectual vision and as the culmination of the contemplation of religious concordance. ${ }^{82}$ Cusanus attempts to unfold the enigmatic aspect of Wisdom and the Word from memory in the flux of conjecture as if peering through a dark mirror. ${ }^{83}$ What does shine forth in De pace fidei is Christ as both creative cataphatic revealer of the concordance of every conceivable religious rite, and as narrow apophatic mystical way to unity beyond the finite dialogical conundrum, "where a sentence has both a beginning and an ending." 4

Cusanus's Christocentric synthesis of religious concordance is formulated through the concepts and categories of Christian theology, Christian Neoplatonic mysticism, and Greek philosophy. Cusanus's frequent use of the word religio in De pace fidei echoes ancient Hellenic ideas, but also Augustine, the great harmonizer of Neoplatonism and Christianity. ${ }^{85}$ In De vera religione, Augustine explores the universal nature of religio, but also moves beyond the dialectic of inclusivity and exclusivity to discover the contemplative within the Christian faith. Cusanus had read Devera religione, and cites the work in Depace fidei. ${ }^{86}$ There, Augustine argues that the good and blessed life "is to be found entirely in the true religion wherein one God is worshipped and acknowledged with purest piety." 87 Furthermore, vestiges of this true religion are to be found everywhere through the agency and providence of Divine Wisdom. ${ }^{88}$ Even so, Augustine summons lovers of wisdom to "turn to God so that we may deserve to be illumined by his Word, the true light." 89 This path is open to everyone.

\footnotetext{
82 De pace fidei I, 1; XIX, 68.

83 De pace fidei $\mathrm{I}, 1$.

84 Augustine, Confessions IX, x (24); English translation by Henry Chadwick (Oxford: Oxford University Press, 1998), 171.

85 Cusanus employs religio or its declensions 27 times throughout De pace fidei.

86 De pace fidei II, 7; De vera religione 39. See critical apparatus of h VII, 8.

87 Augustine, De vera religione I, 1; translation in John H. S. Burleigh, trans., Augustine: Earlier Writings, The Library of Christian Classics, vol. VI (Philadelphia: Westminster Press, 1953), 225. Cf., De pace fidei I, $5^{-6 .}$

88 De vera religione XXXIX, 72; trans. Burleigh, p. 262. Cf., De pace fidei IV, 10-12.

89 De vera religione XLII, 79; trans. Burleigh, p. 266.
} 
There is one God alone to be worshipped, according to Augustine, "and [it is] his Wisdom who makes every wise soul wise." ${ }^{90}$ Augustine concludes De vera religione by urging: "Let our religion bind us to the one omnipotent God, because no creature comes between our minds and him whom we know to be the Father and the Truth, i.e., the inward light whereby we know him." ${ }^{\prime 1}$ As Wilfred Cantwell Smith detects, Augustine barely mentions Christianity in De vera religione, and instead, "[t]he culmination is mystic," ${ }^{92}$ much like the ideal religious dialogue envisioned by Cusanus in the framework of contemplation. ${ }^{93}$ For religio is the bond that unites creatures to the Creator, the Truth and inner light of revelation. Smith also reminds us that the non-Augustinian introduction of the post-enlightenment notion of revealed religion into eighteenth-century Europe has led to confusion. ${ }^{94}$ Cusanus, however, as inheritor of ancient and Augustinian contemplative and universal concepts of religion, reminds readers who venture into his conceptual context that God does not reveal religions, but rather, God reveals God's self as the way and means to beatitude and religious concordance: the Word in relation to words, the finite in hierarchical dialectical gradations to the infinite. Cusanus's religion is not one of the many religions, but the religion: the peace of faith for the peace of the cosmos. In Cusanus's all-encompassing vision and conception of one religion in the variety of rites we detect not even a hint of Pascal's matter of the heart, nor Schleiermacher's intuition of the numinous universe. ${ }^{95}$ As Biechler and Bond note, there are indeed pointers to Luther in De pace fidei, regarding religion and justification by faith. ${ }^{96}$ For Cusanus, this peace of faith is bonded to its object: the Word, the dialogical-incarnational and cosmic-hierarchical

$90 \quad$ De vera religione LV, 112; trans. Burleigh, p. 282.

91 De vera religione LV, 113; trans. Burleigh, p. 282.

92 Wilfred Cantwell Smith, The Meaning and End of Religion: A New Approach to the Religious Traditions of Mankind (New York: Mentor Books, 1964), 31.

93 De pace fidei I, 1.

94 Smith, Meaning and End of Religion, 116.

95 Blaise Pascal, Pensées (Brunschvicg, 1897 edition), 277: "Le coeur a ses raisons que la raison ne connaît point; on le sait en mille choses. Je dis que le coeur aime l'être universel naturellement, et soimême naturellement selon qu'il s'y adonne; et il se durcit contre l'un ou l'autre à son choix." In his second speech, Schleiermacher writes: "I entreat you to become familiar with this concept: intuition of the universe. It is the hinge of my whole speech; it is the highest and most universal formula of religion on the basis of which you should be able to find every place in religion, from which you determine its essence and its limits" (Friedrich Schleiermacher, On Religion: Speeches to its Cultured Despisers, trans. and ed. Richard Crouter (Cambridge: Cambridge University Press, 1996), 24).

96 On faith in De pace fidei, see Biechler and Bond's introduction to Nicholas of Cusa on Interreligious Harmony, xxxvi-xlviii. 
Word of God, through which all things are enfolded and unfolded. ${ }^{97}$ Cusanus even peers subtly ahead to a central tenet of Christian theology, reaffirmed in the Lutheran Confessions: the ubiquity of Christ. ${ }^{98}$

\section{Reading the Christology of De pace fidei in Contemporary Christian-Muslim Dialogue}

Given Cusanus's penchant for Christocentric theology and Greek philosophy, his ideas on one religion in the variety of rites are not without criticism. First and foremost, Cusanus had no real exposure to Muslims, ${ }^{99}$ though for a churchman of his time and place he was remarkably well versed on Islam. ${ }^{100}$ Nonetheless, today he would sound naïve in his belief that rational discourse could indeed achieve lasting religious peace between these two great Abrahamic faiths. Secondly, Cusanus may indeed be guilty of the fallacy of equivocation: while the theological subjects may be the same for Christians and Muslims - for example God, Word, prophets - the predicates are nevertheless different. Thirdly, in our fragmented contemporary world, we have, no doubt, lost faith in the power of logical, dialectical thought as envisioned in De pace fidei. Perhaps it never really worked in reality, but only in Plato's and Cusanus's imaginations. Finally, what about the uniqueness of Christ as mediator between the infinite and finite, God and humanity? ${ }^{101}$ For Augustine, this was not to be found in the books of the Platonists. ${ }^{102}$ Cusanus, on the other hand, seems to suggest in De veneratione sapientiae that Wisdom-Word is found everywhere, or at least in all of the great thinkers, pagan and Christian alike. The Cribratio even shows that he found the concept of Wisdom as incarnate in Christ within the Qur'an. Perhaps, in the end, Cusanus conceived of an all-encompassing religion unrecognizable to both Christians and Muslims. We would do well, however, to approach Cusanus through his own words.

\footnotetext{
97 De pace fidei II, 7.

98 Cf., Formula of Concord, Article VIII.

99 See Cusanus's recounting of possible interactions with Muslim converts to Christianity in Cribratio Alkorani, prologus 3 .

100 For example, Cod. Cus. 205 includes Al-Ghazali on philosophy, Lib. De universali philosophia, with notes by Cusanus, and Avicenna's Metaphysics with a note by Cusanus on f. 8ov. Cod. Cus. 108 contains Ketton's translation of the Qur'an, with numerous notes by Cusanus. For the sometimes inaccurate catalogue to Cusa's library in Kues, see: J. Marx, Verzeichnis der Handschriften-Sammlung des Hospitals zu Cues bei Bernkastel a./Mosel (Trier: Druck der Kunst- und Verlagsanstalt Schaar \& Dathe, Komm.-Ges. a. Akt., 1905).

101 John 14:6. Cf., Cusanus, Sermon CLXXXVI; Sermon CCIII.

102 Augustine, Confessions VII, ix, 13-14.
} 
Therefore, it may be hoped that a theological reading of De pace fide $i$ leads to a greater appreciation of Cusanus's thesis of one religion in the variety of rites, as well as an appreciation of his understanding of the peace of faith through the Word of God as metaphysically rooted in Hellenic thought and the plentitude of ancient conciliar Christology.

Cusanus's conception of the connection between heavenly and earthly, or church and world, is located in the transcendent-immanent Christ, who is both divine wisdom (universalist) and the incarnate Word (exclusivist). As demonstrated by Leo's Tome, cited by Cusanus at the outset of Cribratio, what he sought to avoid was schism - the schism of Christianity and Islam, or any schism between reason and revelation, or between the exclusivity and inclusivity of ancient and conciliar Christology. The concordantia is in and through Christ, the Wisdom of God. With this in mind, three general approaches to religion and religious diversity may be formulated: all religions are the same, all religions are different, or religions exist as unity in plurality. From these, Cusanus comes closest to the third option. For Cusanus, religion is one and cosmic in range and effect, yet rites are many and diffuse in practice. Moreover, rites remain distinct and yet wholly part of one religion. Cusanus, therefore, seems to hold universal and exclusive together dialectically, and through an imagined contemplative and conciliar dialogue, discovers a religious synthesis. There are striking similarities here to the fourth- and fifth-century conciliar Christological debates and formulations over holding to one hypostasis/ persona in two distinct but inseparable natures. De pace fidei sometimes accentuates the exclusive character of the Christian faith, while at other times highlights the universal scope of Wisdom through the plethora of religious rites. Yet ultimately, for Cusanus, truth is found in the Word of God, who "is all and in all."103 While, no doubt, this may prove troubling to Christians and Muslims today, it seems to be truer to Cusanus's thought and intentions. By letting Cusanus speak, we might hear that De pace fidei has something to say to the complexities of our multi-religious world. The ongoing work of finding common ground and conversation instead of conflict continues in such landmark efforts as the textually focused $A$ Common Word.

While Cusanus lived in what he conjectured were the last days, he creatively constructed the contemplative dialogue of De pace fidei as a religious synthesis in a world drastically demarcated by belief. Of course, contra Cusanus, the world did not end in the fifteenth century. Against his archetypal meditations on the peace of faith, violence has perpetuated but religion persists. Throughout the vicissitudes of past and present, Cusanus's prayer for

103 De pace fidei II, 7; Colossians 3:11 NRsv. 
religious peace continues to resonate. The fifteenth century, while no stranger to end-time fervor, was in Southern's terms 'a moment of vision' for Christians perceiving Islam. ${ }^{104}$ These visions of peace, however, were soon eclipsed by the realities of war. Today, through a religious dialogue like A Common Word, we perchance glimpse the moment of vision anew. Amidst proponents of apocalyptical clashes of civilizations and religious conflagrations, Cusanus's De pace fidei reminds both Christians and Muslims of their shared philosophical concepts and the recurrent need for respectful and honest conversation. From a Christian perspective, Cusanus maintains the tension between universality and exclusivity inherent in ancient and conciliar Christology. In so doing, he ultimately points to the dialectical and hierarchical cosmic fullness of the hypostases of the Logos. While Christians and Muslims will continue to differ on fundamental points of belief and practice, adherents of both great Abrahamic faiths still pray along with Cusanus for peace. And, for the fifteenth-century theologian Nicholas of Cusa, the common word for peace between Christians and Muslims is none other than Jesus Christ.

104 The title of chapter three of R. W. Southern's now classic lectures, Western Views of Islam in the Middle Ages (Cambridge: Harvard University Press, 1962), 67-109. 


\title{
The Trinity as a Challenge to Christian-Muslim Dialogue in Nicholas of Cusa: Nicholas of Cusa's Philosophical Translation of Trinitarian Faith as a Response to Islamic Rejection
}

\author{
Felix Resch
}

Nicholas of Cusa provides an interesting example of fostering a ChristianMuslim dialogue. ${ }^{1}$ Thus, the focus of this essay is on Cusa's method of dealing philosophically with the Islamic accusations raised against the Christian doctrine of the Trinity. To explore this topic, I will first of all contrast contemporary interreligious dialogue with Cusa's interreligious dialogue, in order to get an idea of what the latter aims at. Then, I will turn to discuss the logical or philosophical objections against the Trinity mentioned in the Qur'an, after which I will examine the ways that Christians could respond to these accusations. Among the different options available, the kerygmatic trinitarian theology, which reduces the three divine persons to proper names of three individual entities, will draw particular attention. Therefore, the philosophical and theological meanings of proper names will also have to be analyzed, in order to understand why Cusa saw the need to translate trinitarian proper names into philosophical concepts, despite the fact that naming the trinitarian God was still important for him.

In our globalized world, characterized by the decline of social, national, political, and religious borders, isolation turns out to be more and more of an

1 Given that there is vast literature on this issue in general, I will just mention some works: Tom Kerger and Walter Andreas Euler, eds., Cusanus und der Islam, 1st ed. (Trier: Paulinus, 2010); Rudolf Haubst, ed., Der Friede unter den Religionen nach Nikolaus von Kues, thematic issue of Mitteilungen und Forschungsbeiträge der Cusanus-Gesellschaft 16 (1984); Walter Andreas Euler, Unitas et Pax: Religionsvergleich bei Raimundus Lullus und Nikolaus von Kues, 2nd ed., Religionswissenschaftliche Studien, 15 (Würzburg: Echter, 1995); Tibor Bakos, On Faith, Rationality and the Other in the Late Middle Ages. A Study of Nicholas of Cusa's manuductive approach to Islam. Dissertation presented to fulfill the requirements for the degree of Doctor (Ph.D.) in Philosophy (Leuven: unpublished dissertation, 2003); Markus Riedenauer, Pluralität und Rationalität: Die Herausforderung der Vernunft durch religiöse und kulturelle Vielfalt nach Nikolaus Cusanus, Theologie und Frieden, 32 (Stuttgart: Kohlhammer, 2007). 
impossible option. As a consequence, each collective entity is forced to adopt an attitude toward the others. Rather than resorting to confrontation, indifference, or surrender, dialogue seems to be the most useful attitude to adopt in order to respect others while remaining faithful to oneself. In our post-9/11 world, we see the urgent need for religions to search for common ground in order to overcome misunderstandings and hostilities, which often lead to violence. Apart from fundamentalists, most religious leaders agree that interreligious dialogue is preferable to forced conversion, as dialogue is used to foster mutual understanding. ${ }^{2}$ Proselytism and syncretism are both excluded as alternatives. $^{3}$

I would call this a hermeneutical dialogue with social implications, enabled by the rise of the modern secular state. ${ }^{4}$ Modern Western societies are based on religious plurality, where due to the secular constitutional and judicial framework, religious diversity must no longer lead to political conflicts. As we know, the origins of the modern secular state are deeply rooted in European history, especially in the experiences of the bloody wars of religion in the Early Modern Age. ${ }^{5}$ That is why in the Late Middle Ages, when religious unity and social peace were still regarded as inseparable, religious diversity was consequently interpreted as a danger for society. Conversely, achieving religious unity was seen as a necessary condition for social peace. Obviously, there are different ways of achieving religious unity. The first method, to conquer or submit to another religion, lost a lot of popularity in the fifteenth

2 A good example of trying to foster mutual theological understanding between Christians and Muslims is Christian W. Troll, Muslime fragen, Christen antworten, Topos-plus-Taschenbücher, 489, 2nd ed. (Regensburg: Pustet, 2004).

3 An interesting example of a grassroots interreligious dialogue is the French organization 'Coexister, founded in 2009 by young Christians, Jews, and Muslims under the slogan "Diversité dans la foi, Unité dans l'action" (http://www.coexister.fr/association.html, accessed December 4, 2012).

4 Ernst-Wolfgang Böckenförde's famous dictum points out that the liberal, secularized state is based on presuppositions that cannot be guaranteed on their own (Ernst-Wolfgang Böckenförde, Staat, Gesellschaft, Freiheit: Studien zur Staatstheorie und zum Verfassungsrecht (Frankfurt: Suhrkamp, 1976), 6o). Hence, Jürgen Habermas insists on the importance of religions as a resource even for a secular society. See Jürgen Habermas, "Glauben und Wissen," in Friedenspreis des Deutschen Buchhandels 2001-Jürgen Habermas, ed. Börsenverein des deutschen Buchhandels, 9-15, especially 13. To fulfill this task, religions are requested to translate their religious contents into a secular language (12-13).

5 Böckenförde, Staat, Gesellschaft, Freiheit, 42-64. 
century. ${ }^{6}$ Thus, in his letter to John of Segovia in 1454, Nicholas of Cusa agrees with his interlocutor that military actions against the expanding Turks should be replaced by rational argumentation, in order to convince the Muslims of central Christian doctrines like the Trinity and the hypostatic union. ${ }^{7}$ In the same work he mentions his dialogue De pace fidei, written one year before, where he had attempted to put such a program into practice. ${ }^{8}$

Since such an endeavor entails the risk of being refuted by the other religion, this attitude presupposes a deep conviction of the rational superiority of Christian faith, as well as an assurance of the importance of a rational discussion between Christians and Muslims, with the aim of defeating the latter through rationality. ${ }^{9}$ Contrary to hermeneutical dialogues, I would call this an

6 On the decreasing approval of combating the Turks after the fall of Constantinople, see Thomas M. Izbicki, "The Possibility of Dialogue with Islam in the Fifteenth Century," in Nicholas of Cusa in Search of God and Wisdom, ed. Gerald Christianson and Thomas M. Izbicki (Leiden: Brill, 1991), 175-185 at 175 .

7 Nicholas of Cusa, "Epistula ad Ioannem de Segobia 2," in Nicolai de Cusa opera omnia iussu et auctoritate academiae litterarum Heidelbergensis ad codicum fidem edita: Volumen VII (Hamburg: Meiner, 1970). In his dialogue with a Persian, held in 1391, the Byzantine Emperor Manuel II considers faith as a fruit of the soul and not of the body (Manuel II. Palaiologos, Dialoge mit einem Muslim, I: Kommentierte griechisch-deutsche Textausgabe von Karl Förstel, Corpus Islamo-christianum: Series Graeca, 4 (Würzburg-Altenberge, 1993), VII. Dialog 1.6, 240-243). Instead of violence, speech and reasoning should be used as tools to convince someone (240-243). On this issue see Pope Benedict's well-known Regensburg lecture held on September 12, 2006, and edited in Benedikt XVI, Glaube und Vernunft. Die Regensburger Vorlesung: Vollständige Ausgabe, commen. Gesine Schwan, Adel Theodor Khoury, and Karl Kardinal Lehmann (Freiburg: Herder, 2006), 15-17. An interesting comparison between Nicholas of Cusa, Manuel II, and Pope Benedict XVI is given in Walter Andreas Euler, Papst Benedikt XVI, Kaiser Manuel II und Kardinal Nikolaus von Kues: Das Verhältnis von Glaube und Vernunft und die christliche Sicht des Islams, 1st ed., Kleine Schriften der Cusanus-Gesellschaft, Heft 17 (Trier: Paulinus, 2007).

8 The Prologue narrates the deep impact the fall of Constantinople has on the author (De pace fidei 1, n. 1 [h VII]) who begs God to end the bloody fights and to overcome religious differences. Thus, God convokes a heavenly council of wise men representing different cultures (3, n. 9). Despite the Christian setting, which is exemplified by the chair of the divine Logos and the Apostles Peter and Paul, all the discussions are held in a rational and peaceful way.

9 I agree with Markus Riedenauer that according to Cusanus, philosophical rationality seems to be the adequate basis for an interreligious dialogue (Markus Riedenauer, Pluralität und Rationalität: Die Herausforderung der Vernunft durch religiöse und kulturelle Vielfalt nach Nikolaus Cusanus, Theologie und Frieden, 32 (Stuttgart: Kohlhammer, 2007), 103). As Thomas M. Izbicki puts it: "Dissent on important matters of belief or practice, especially dissent based on a clear, informed conscience, was almost incomprehensible to the intellectual leaders of Europe" (Izbicki, "The Possibility of Dialogue with Islam in the Fifteenth Century," 183). 
alethic dialogue, the main goal of which is not to give testimony to one's own faith without commenting on the other, but rather, to scrutinize the articles of faith - in particular the Trinity and the hypostatic union - through natural reason. This is possible because the Christian and Muslim religions are not mere psychological phenomena, but instead entail an alethic dimension ${ }^{10}$ and raise absolute and universal truth claims. ${ }^{11}$

Given that Christians and Muslims hold contradictory positions toward God's personality and revelation, both positions cannot be true; according to the law of non-contradiction, one must be true and one must be false. Within this logical framework, the epistemic challenge consists in finding out which position is in fact true. ${ }^{12}$

\section{The Logical and Doxological Accusations Raised against the Doctrine of Christian Trinity in the Qur'an}

To better understand how Cusa's trinitarian faith was challenged by Islam, I cite one of the most significant Qur'anic rejections of the Christian doctrine of the Trinity, which is found in Sura 4:171-172:

People of the Book, do not transgress the bounds of your religion. Speak nothing but the truth about God. The Messiah, Jesus the son of Mary, was no more than God's apostle and His Word which he cast to Mary: a spirit from Him. So believe in God and His apostles and do not say: 'Three.' Forbear, and it shall be better for you. God is but one God. God forbid that He should have a son! His is all that heavens and the earth contain. God is the all sufficient protector. The Messiah does not disdain to be a servant

10 Of course, they entail other dimensions as well, like an aesthetical or ethical one, the latter of which is underlined by Hans Küng's well-known 'Global Ethic.' See Küng, Projekt Weltethos (Munich: Piper, 1990).

11 On the absolute and universal truth claims of the three monotheistic world religions, see Markus Enders, “'Denn Gott ist die Wahrheit' (Koran 22,6 63; 31.30): Anmerkungen zum Wahrheitsverständnis und zu den Wahrheitsansprüchen der drei monotheistischen Weltreligionen," Philotheos. International Journal for Philosophy and Theology 12 (2012): 17-35; on the importance of philosophy in interreligious dialogue, see Josef Schmidt, S. J., "Zur Bedeutung der Philosophie im Religionsdialog," Jahrbuch für Religionsphilosophie 9 (2010): 9-24.

12 On the systematic and historical aspect of conflicting truth claims in the Renaissance, see the excellent epilogue in Paul Richard Blum, Philosophy of Religion in the Renaissance (Farnham: Ashgate, 2011), 177-183. 
of God, nor do the angels who are nearest to Him. Those who through arrogance disdain His service shall be brought before Him. ${ }^{13}$

With respect to content, we find two accusations raised against the Christians in this passage. First, the doctrine of the Trinity is incompatible with God's unity. Second, the christological doctrine of the hypostatic union, or Jesus Christ's divine sonship, is incompatible with God's transcendence. Both are logical objections assuming a formal contradiction between the core doctrines of the Christian faith and God's true nature. Finally, both correspond to Islam's doxological accusation of shirk, i.e., associating someone or something with God, ${ }^{14}$ which is contrary to tawhid, the traditional Islamic confession of God's unity. ${ }^{15}$

It is interesting to observe that in Sura 4:171-172, the Trinity doctrine is only rejected, but not elucidated in detail. Rather, the emphasis lies on the interpretation of Jesus Christ. On the one hand, Jesus, who is conceived in a miraculous way by the Virgin Mary, ${ }^{16}$ is said to deserve the title 'Messiah. ${ }^{17}$ On the other hand, Christians are accused of assigning a son to God and divinizing Jesus, although according to the Qur'an, he only claimed to be a servant of God. The sura underlines the absolute transcendence of God, who possesses "all that the heavens and the earth contain." Each being depends on his will, because all are created by him. ${ }^{18}$ Hence, the general relationship between all creatures and their creator can never be replaced by a special relationship between the son and his father.

Another text, Sura 5:116-118, deepens the impression that Christian doctrines do not remain faithful to Jesus Christ's own teaching:

13 Sura 4:171-172. All English translations of Qur'anic suras are taken from N. J. Dawood, The Koran: Translated with notes by N. J. Dawood, 5 th revised ed. (London: Penguin, 1990).

14 On this issue, see Muhammad Ibrahim H. I. Surty, The Qur'ān and Al-Shirk (Polytheism), 2nd revised ed. (London: Ta-Ha, 1990). The doxological accusation is also raised against the ecclesiastic hierarchy: "They make of their clerics and their monks, and of the Messiah, the son of Mary, Lords besides God; though they were ordered to serve one God only" (Sura 9:31).

15 Sandra Toenies Keating, "'Say Not Three': Some Early Christian Responses to Muslim Questions on the Trinity," The Thomist 74 (2010): 85-104 at 86.

16 Khoury states that it is his virgin birth that makes Jesus so pure that he can be called 'spirit from God' (Adel Theodor Khoury, Der Koran: Übersetzt und kommentiert von Adel Theodor Khoury (Gütersloh: Gütersloher Verlagshaus, 2007), 155, note 4, 171).

17 On Jesus' peculiar prophetic mission, see Sura 3:48-55.

18 E.g., Sura $36: 81-82$. 
Then God will say: "Jesus, son of Mary, did you ever say to mankind: 'Worship me and my mother as gods besides God?'” "Glory to You," he will answer, "how could I ever say that to which I have no right? If I had ever said so, You would have surely known it. You know what is in my mind, but I know not what is in Yours. You alone know what is hidden. I told them only what You bade me. I said: 'Serve God, my Lord and your Lord.' I watched over them while living in their midst, and ever since You took me to Yourself, You have been watching over them. You are the witness of all things. If You punish them, they surely are Your servants; and if You forgive them, surely You are mighty and wise. ${ }^{19}$

In this passage, Jesus Christ is presented as God's prophet, who claims that neither he nor his mother is to be worshipped as God. ${ }^{20}$ Obviously, this sura rejects the idea of a familial Trinity made up of Father, Mother, and Son. ${ }^{21}$ However, Sura 5:72-73 makes it clear that any type of Trinity is considered a violation of tawhid, because being reduced to one of three persons, God is no longer one:

Unbelievers are those that say: "God is the Messiah, the son of Mary." For the Messiah himself said: "Children of Israel, serve God, my Lord and your Lord." He that worships other gods besides God, God will deny him Paradise, and Hell shall be his home. None shall help the evil-doers. Unbelievers are those that say: "God is one of three." There is but one God. If they do not desist from so saying, those of them that disbelieve shall be sternly punished.22

This sura leaves no doubt that unbelievers, i.e. everyone committing shirk, shall be punished in hell.

\section{How Should Christians Respond?}

There are several different ways to respond to such accusations. The first option would be to surrender. Seeing no possibility of refuting the Islamic objection

\footnotetext{
19 Sura 5:116-118.

20 Sura 5:17 repeats that Jesus and Mary are creatures depending totally on God's will: "Say: 'Who could prevent God, if He so willed, from destroying the Messiah, the son of Mary, his mother, and all the people of the earth? [...]."

21 On this issue see Khoury, Der Koran, 155, note 4,171.

22 Sura $5: 72-73$.
} 
against the trinitarian doctrine, the Christian interlocutor could admit that the assertion that God is triune is incompatible with the assertion that God is one. Remaining faithful to the latter, he would consequently give up the first. ${ }^{23}$ Such a strategy could be motivated by a strong admiration for the monotheistic heritage, while underestimating the rationality of trinitarian belief. It is evident that this option abandons orthodox Christian faith. ${ }^{24}$

A second option would be confrontation. Instead of trying to refute the Islamic objection against trinitarian doctrine, the Christian interlocutor could begin to distract the Muslim's attention by raising other objections against Islam, or simply enter into polemics. Obviously, this option would turn out to be an intellectual non-starter.

The third option, however, seems to be much more subtle. Apparently, indifference can help to deal with accusations raised against the trinitarian doctrine. Philosophical or logical objections could seduce the Christian interlocutor to withdraw from a speculative trinitarian theology by taking refuge in a mere kerygmatic trinitarian theology. ${ }^{25}$ Instead of refuting the Islamic attack, the Christian could remind the Muslim interrogator of the salvific history where God reveals himself as trinitarian. This includes a shift in emphasis from the immanent to the economic Trinity. Rediscovering the particular role each divine figure plays in the salvific history, this option takes 'Father,' 'Son,' and 'Holy Spirit' primarily as proper names of individual entities.

In the next section, I will discuss the philosophical and theological meanings of proper names in order to show why they are not sufficient for an adequate understanding of the Trinity. This will also elucidate why Cusa saw himself challenged to translate trinitarian proper names into philosophical concepts.

\section{Philosophical and Theological Considerations on Proper Names}

In the last few decades, proper names have drawn a lot of philosophical interest, especially by analytic philosophers. One of the most interesting theories

23 On the development of non-trinitarian theologies see Gavin D'Costa, "The Trinity in Interreligious Dialogues," in The Oxford Handbook of the Trinity, ed. Gilles Emery, O. P. and Matthew Levering (Oxford: Oxford University Press, 2011), 573-585 at 574-576.

24 The modalistic view arguing that 'Father,' 'Son,' and 'Holy Ghost' are only three names for one and the same entity without any real distinction boils down to the same heterodox result.

25 E.g., Jürgen Moltmann, Trinität und Reich Gottes: Zur Gotteslehre (Munich: Kaiser, 1980); Barbara Andrade, Gott mitten unter uns: Entwurf einer kerygmatischen Trinitätstheologie, Europäische Hochschulschriften, 631 (Frankfurt: Lang, 1998). 
is Saul A. Kripke's Theory of Reference. In his lectures Naming and Necessity, held in January of 1970 at Princeton University, he treats proper names as rigid designators. ${ }^{26}$ While rejecting Gottlob Frege's and Bertrand Russell's reduction of proper names to definite descriptions, Kripke points out the essential role proper names play to guarantee transworld identity:

One of the intuitive theses I will maintain in these talks is that names are rigid designators. Certainly, they seem to satisfy the intuitive test mentioned above: although someone other than the U.s. President in 1970 might have been the U.s. President in 1970 (e.g., Humphrey might have), no one other than Nixon might have been Nixon. In the same way, a designator rigidly designates a certain object if it designates that object wherever the object exists; [...]. [...] Those who have argued that to make sense of the notion of rigid designators, we must antecedently make sense of 'criteria of transworld identity' have precisely reversed the cart and the horse; it is because we can refer (rigidly) to Nixon, and stipulate that we are speaking of what might have happened to him (under certain circumstances), that 'transworld identifications' are unproblematic in such cases. ${ }^{27}$

Kripke argues that the main reason for searching for criteria or descriptions to identify an object is the confusion of the metaphysical and the epistemological dimension, or, in other terms, of necessity and a prioricity. ${ }^{28}$ If one holds that objects are identified in all possible worlds by a property or a set of properties known a priori, he ignores that "( 1 ) Generally, things aren't 'found out' about a counterfactual situation, they are stipulated; (2) possible worlds need not be given purely qualitatively, as if we were looking at them through a telescope."29 What Kripke offers, therefore, is a different view on beings, which is not driven by an attempt to reduce individual entities to bundles of properties, but rather, by a desire to reestablish the ontological primacy of the substance. ${ }^{30}$ Hence, he tries to fix reference by what he calls an "initial "baptism."'31 Here, it is the name "'passed from link to link" 32 that marks exactly an individual being. Recently,

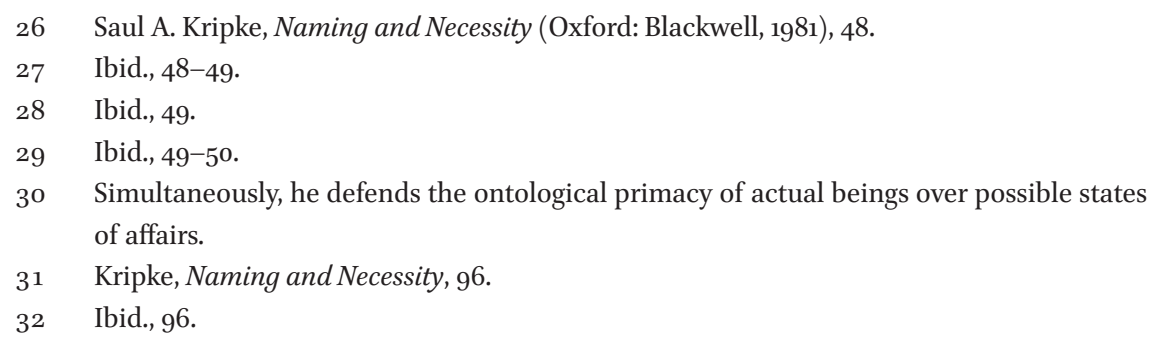


Kripke's insistence on proper names has been adopted by Robert Spaemann for the purposes of philosophical theology. In his speech Was ist das, 'quod omnes dicunt deum'? held in March of 2011 in Tübingen, Spaemann attempts to treat the word 'God' as a proper name, ${ }^{33}$ arguing that its reference is fixed by a causal chain dating back to a kind of 'initial baptism.' According to Spaemann, we can only believe that this causal chain is without a gap. ${ }^{34}$

In his book Trinität und Reich Gottes, published in 1980, Jürgen Moltmann treats even the trinitarian names as proper names. ${ }^{35}$ Consequently, he rejects the concepts of substance and subject to explain the unity of the three trinitarian figures. Rather, he considers the Father, the Son, and the Holy Spirit as three different subjects playing different roles in the trinitarian history. ${ }^{36}$ According to Moltmann, even the unity of these three must be understood in a trinitarian way: the Father as the origin, the Son as the mutual consent, and the Holy Spirit as the glorifying community. ${ }^{37}$ It is hard to see how this kind of social trinity avoids the danger of tritheism. ${ }^{38}$

Taking the Father, the Son, and the Holy Spirit as three numerically different subjects who share one common predicate 'God' is incompatible with monotheism. In this case, God would be reduced to a mere universal, thus the Islamic objections would be justifiable. The only way I see how to refute these objections and make sure that Christian trinitarian faith is indeed monotheistic is through an alethic dialogue, which still remains as a fourth option for Christians to turn to when responding to the Qur'anic accusations. Since Muslims do not share the same source of revelation, Christians have to translate the revealed proper names-'Father,' 'Son,' and 'Holy Spirit' - into philosophical concepts, in order to foster communicability and claim absolute and universal truth.

In the following section I will therefore focus on Cusa's translation of the trinitarian proper names into philosophical concepts, within the framework of his dialogue with Islam.

33 Robert Spaemann, "Was ist das, 'quod omnes dicunt deum'?, in Gottesbeweise als Herausforderung für die moderne Vernunft, ed. Thomas Buchheim, Friedrich Hermanni, Axel Hutter, and Christoph Schwöbel, Collegium Metaphysicum, 4 (Tübingen: Mohr Siebeck, 2012), 33-45 at 37 .

34 Spaemann, "Was ist das, 'quod omnes dicunt deum'?," 37.

35 Moltmann, Trinität und Reich Gottes: Zur Gotteslehre, 179-194.

36 Ibid., 173-174.

37 Ibid., 194.

38 On tritheism, see Christophe Erismann, "The Trinity, Universals, and Particular Substances: Philoponus and Roscelin," Traditio 63 (2008): 277-305. 


\section{Cusa's Translation of Trinitarian Proper Names}

Generally speaking, in Cusa's works we find two different approaches to Islam. First, there is his philosophical approach, the manuductio of Muslims toward the Mystery of the Trinity, especially in De pace fidei and parts of Cribratio Alkorani. Second, there is his exegetical approach, the pia interpretatio of the Qur'an in Cribratio Alkorani. ${ }^{39}$ In this essay, I will only focus on the first one, for which I hold that Cusa uses a double strategy: on the one hand, he shares the Muslim concern about God's unity, while on the other hand, he attempts to convince the Muslims that God is in fact triune.

In Chapter 8 of De pace fidei, the Chaldean interlocutor picks up the traditional accusation of shirk: "But the view that God has a Son and that He partakes of the deity - this the Arabs (and many [others] along with them) call into question." 40 Thus, the Divine Word as Cusa's spokesman is forced to translate the trinitarian proper names into philosophical concepts:

Some [writers] name Oneness Father, Equality Son, and Union Holy Spirit because these terms, though not proper, nonetheless signify the Trinity suitably. For the Son is from the Father; and Love, or Spirit, is from Oneness and from the Son's Equality. For the nature of the Father passes over into a certain equality in the Son; therefore, Love-and-Union arises from Oneness and Equality. And if simpler terms could be found, they would be more fitting - as are Oneness, Itness, and Sameness. For these terms seem to explicate better the most fecund simplicity of the essence. And since in the essence of the rational soul there is a certain fecundity_viz., mind, wisdom, and love, or will—notice that mind, of itself, begets understanding or wisdom, from which [proceeds] will, or love.

39 On this issue, see Tom Kerger, Pia interpretatio: Vier christliche Theologen im Gespräch mit dem Islam, 1st ed., Trierer theologische Studien, 75 (Trier: Paulinus, 2010); Ludwig Hagemann, Der Kur'än in Verständnis und Kritik bei Nikolaus von Kues: Ein Beitrag zur Erhellung islämisch-christlicher Geschichte, Frankfurter theologische Studien, 21 (Frankfurt: Knecht, 1976); Jasper Hopkins, "The Role of pia interpretatio in Nicholas of Cusa's Hermeneutical Approach to the Koran," in Concordia discors, ed. Gregorio Piaia (Padua: Antenore, 1993), 251-273.

40 Jasper Hopkins, Nicholas of Cusa's De pace fidei and Cribratio Alkorani: Translation and Analysis, 2nd ed. (Minneapolis, MN: Banning, 1994), 645. De pace fidei 8, n. 23: "Sed quod Deus habeat filium et participem in deitate, hoc impugnant Arabes et multi cum ipsis." 
And this trinity in the soul's oneness of essence is a fecundity which [the soul] has in likeness to the most fecund uncreated Trinity. ${ }^{41}$

It is noteworthy that within the henological-apophatic framework of Cusanian metaphysics, even the names of the trinitarian characters are not adequate to express the ineffable mystery of the Trinity. ${ }^{42}$ This is perhaps one of the most striking facts for a Christian philosopher. ${ }^{43}$ Unlike Thomas Aquinas, ${ }^{44}$ Cusa explicitly states that the trinitarian names, though 'suitable' (convenienter), are not proper (non sint proprii). Philosophical concepts like 'Oneness,' 'Equality,' and 'Union,' or alternatively 'Oneness,' 'Itness,' and 'Sameness,' are much more precise because they are simpler and less anthropomorphic. This triadunitas, aequalitas, and conexio or concordia - goes back to Augustine's De doctrina christian $a^{45}$ and was developed further by the School of Chartres,

41 Ibid., 645-646. De pace fidei 8, n. 24: "Nominant aliqui unitatem Patrem, aequalitatem Filium, et nexum Spiritum Sanctum; quia illi termini etsi non sint proprii, tamen convenienter significant trinitatem. Nam de Patre Filius, et ab unitate et aequalitate Filii amor seu Spiritus. Transit enim natura Patris in quandam aequalitatem in Filio. Quare amor et nexus ab unitate et aequalitate exoritur. Et si simpliciores termini reperiri possent, aptiores forent, ut est unitas, iditas et idemptitas. Hii enim termini magis videntur fecundissimam essentiae simplicitatem explicare. Et attende, cum in essentia rationalis animae sit quaedam fecunditas, scilicet mens, sapientia et amor seu voluntas, quoniam mens ex se exerit intellectum seu sapientiam, ex quibus voluntas seu amor, et est haec trinitas in unitate essentiae animae fecunditas quam habet in similitudine fecundissimae increatae trinitatis."

42 A similar position is held in De docta ign. I, 9 (h I), Sermo XXII (h XVI4 n. 21), and De non aliud 5 (h XII).

43 See Gilson's reaction in Etienne Gilson, Die Metamorphosen des Gottesreiches, trans. U. Behler (Munich: Schöningh, 1959), 169: "Unmöglich kann man sich dem Buchstaben des Dogmas gegenüber noch fügsamer zeigen. Die Einheit im Glauben, von der Nikolaus träumt, wird es nicht einmal mehr erfordern, daß man vom Vater, Sohn und Heiligen Geist spricht."

44 Thomas, "STh I q. 33 a. 2," in Editio Leonina: Sancti Thomae Aquinatis doctoris angelici Opera omnia iussu impensaque Leonis XIII. P.M. edita: Tomus quartus: Pars prima Summae theologiae: A quaestione 1 ad quaestionem XLIX ad codices manuscriptos vaticanos exacta cum commentariis Thomae de Vio Caietani Ordinis Praedicatorum S.R.E. Cardinalis cura et studio fratrum eiusdem ordinis (Rome: Ex Typographia Polyglotta S. C. de Propaganda Fide, 1888), 359 .

45 Augustine, "De doctrina christiana I, V, 5," in Aurelii Augustini Opera: Pars IV,1: Sancti Aurelii Augustini De doctrina christiana-De vera religione, ed. Josef Martin, Corpus Christianorum: Series Latina, 32 (Turnhout: Brepols, 1962), 9. 
especially Thierry of Chartres. ${ }^{46}$ In his main work, De docta ignorantia, Cusa dedicates two chapters to this triad in order to elucidate the intradivine processions. ${ }^{47}$ There he also mentions the triad unitas, iditas, and identitas. ${ }^{48}$

The passage cited above from De pace fidei makes it clear that Cusa is truly aware of the difficulties a naïve discussion about the Trinity could cause in the Muslim world. It is interesting to observe that the Chaldean interlocutor's concern about monotheism produces a certain backlash in the answer of the Divine Word, who denies that the trinitarian names of the Christian creed are proper names. So Cusa's trinitarian speculation also contributes to a certain demythologization or purification of the Trinity doctrine from popular misunderstandings.

The tools necessary for this demythologization process are unitymetaphysics and negative theology. Thus, since God is beyond any human concept, even religious concepts lose their weight. Accordingly, Cusa's reading of Neoplatonic sources like Proclus ${ }^{49}$ shows his optimism in assuming that religious differences consist much more in a different manner of speaking (in modo dicendi) than in different eternal truths. ${ }^{50}$ Passing from the logical to the ontological level, the cardinal insists on the absolute transcendence, infinity, and oneness of God, who is beyond all otherness. Hence, it is impossible that there is any otherness, i.e., numerical difference between the three divine persons, because numerically different entities would be plural—and therefore, in theological terms, created. In De non aliud, Cusa explicitly remarks: "non aliud est non aliud quam non aliud."51

46 Thierry's use of this triad is vast in his most important works-Commentum, Lectiones, Glosa, and Tractatus de sex dierum operibus - which are edited in Nikolaus M. Häring, ed., Commentaries on Boethius by Thierry of Chartres and his School (Toronto: Pontifical Institute of Medieval Studies, 1971).

47 De docta ign. I, 8-9.

48 Ibid., I, 9.

49 On Proclus, see Werner Beierwaltes, Proklos: Grundzüge seiner Metaphysik, 2nd revised and extended ed., Philosophische Abhandlungen, 24 (Frankfurt: Klostermann, 1979).

50 In the margin 557 to the 7 th book of Proclus' In Parmenidem, Cusa writes: “[... ] videtur igitur subtiliter consideranti. in modo dicendi pocius esse diuersitatem, inter platonicos iudeos cristianos et arabes" (Marg. 557, CUSANUS-Texte: III. Marginalien:2. Proclus Latinus: Die Exzerpte und Randnoten des Nikolaus von Kues zu den lateinischen Übersetzungen der Proclus-Schriften: 2.2. Expositio in Parmenidem Platonis, ed. Karl Bormann: Vorgelegt am 23. Mai 1985 von Werner Beierwaltes, Abhandlungen der Heidelberger Akademie der Wissenschaften: Philosophisch-historische Klasse: Jahrgang 1986: 3. Abhandlung (Heidelberg: Winter, 1986), 136-137).

$5^{1} \quad$ De non aliud 1. 
Within Cusa's unity-metaphysics, the principle of presupposition plays a key role. Thus, in chapter 4 of De pace fidei the Greek interlocutor states that all philosophers presuppose wisdom, ${ }^{52}$ in chapter 5 the Italian holds that God must be wisdom, ${ }^{53}$ and in chapter 6 , the Arab agrees that even polytheists presuppose divinity as the eternal principle in which the particular gods participate. ${ }^{54}$ According to Nicholas of Cusa, the common ground of different religions is absolute oneness, which is explicitly presupposed by monotheists and implicitly presupposed by polytheists. ${ }^{55}$ However, his search for common ground must not be misunderstood as a pluralistic theology of religions, ${ }^{56}$ because he attempts to point out that Christian core doctrines like the Trinity or the Incarnation are also presupposed by people from other religious traditions, especially by Muslims.

If we take another look at the passage cited above from chapter 8 of $D e$ pace fidei, we can understand the reason why Cusa insists on the trinitarian structure of God. Here, he establishes an analogy between the fecundity of the human mind and the fecundity of the divine mind. As the human mind begets wisdom or understanding, the divine mind similarly begets divine wisdom. Like the human mind and wisdom, the divine mind and wisdom are also both connected by will or love. ${ }^{57}$ This analogy is made possible because every creature receives its being and fecundity from its creator, who must therefore be considered fecund as well. 58

\footnotetext{
$52 \quad$ De pace fidei 4 , n. 11.

53 Ibid., 5 , n. 14 .

54 Ibid., 6, n. 17.

55 On this issue, see Klaus Kremer, "Die Hinführung (manuductio) von Polytheisten zum Einen, von Juden und Mohammedanern zum Dreieinen Gott," in Der Friede unter den Religionen nach Nikolaus von Kues, ed. Rudolf Haubst, thematic issue of Mitteilungen und Forschungsbeiträge der Cusanus-Gesellschaft 16 (1984): 126-163; Markus Enders, "Die eine (wahre) Gottesverehrung in der Vielfalt der Religionen: Zur Begründungsfunktion der spekulativen Einheitsmetaphysik des Cusanus für seine Vision eines immerwährenden Religionsfriedens," in Metaphysik und Religion: Die Wiederentdeckung eines Zusammenhanges, ed. Hermann Deuser, Veröffentlichungen der wissenschaftlichen Gesellschaft für Theologie, 30 (Gütersloh: Gütersloher Verlagshaus, 2007) 119-153.

56 E.g., John Hick and Paul F. Knitter, eds., The Myth of Christian Uniqueness: Toward a Pluralistic Theology of Religions (Maryknoll, NY: Orbis, 1987). Some critical remarks are given in Gavin D'Costa, ed., Christian Uniqueness Reconsidered: The Myth of a Pluralistic Theology of Religions (Maryknoll, NY: Orbis, 1990).

57 De pace fidei 8 , n. 24.

$5^{8}$ Ibid., 8, n. 24.
} 
It appears that the Divine Word tries to convince its Chaldean interlocutor by claiming: Whoever affirms that God is the creator and the fecund source of all, must affirm that he is triune. Evidently, in order to guide its interlocutor to the trinitarian God, the Divine Word does not resort to supernatural sources of revelation or to salvific history, but rather to natural knowledge. In this vein, Cusa follows the Iberic tradition of the Castilian John of Segovia ${ }^{59}$ and the Catalans Raymond Lull ${ }^{60}$ and Raymond of Sabunde, ${ }^{61}$ all of whom saw the urgent need to convert Muslims by proving disputed doctrines like the Trinity through reason. Consequently, Cusa's philosophical translation of the trinitarian doctrine is open to public — but profoundly metaphysical—reason. In this respect, he differs significantly from modern postmetaphysical philosophers like Habermas. ${ }^{62}$

The main problem, though, still needs to be solved: How can Cusanus overcome the apparent contradiction between the negation of otherness in God and the affirmation that God is in fact triune? Following Boethius' De Trinitate ${ }^{63}$ the cardinal maintains that the trinitarian persons only differ in relation to each other but not in their essence, in contrast to the varying nature of numerically different, finite beings. ${ }^{64}$ Since the Trinitarian figures therefore do not violate absolute unity, they neither multiply God nor limit each other. Hence, the Islamic accusation of shirk is philosophically rejected.

59 On John of Segovia's apologetics, see Darío Cabanelas Rodríguez, Juan de Segovia y el problema islámico (Madrid: Universidad de Madrid, 1952).

60 On Raymond Lull's apologetics, see Viola Tenge-Wolf, "Erstes Kapitel: Allgemeine Einführung," in Doctoris Illuminati Raimundi Lulli Opera latina cum cura et studio Instituti Raimundi Lulli in Universitate Friburgense Brisigavorum ad fidem codicum manu scriptorum edita: Tomus XXVII: 53: Tabula generalis In mari in portu Tunicii in medio septembris anno MCCXCIII incepta et in civitate Neapolis in octavis Epiphaniae anno MCCXCIV ad finem perducta, ed. Viola Tenge-Wolf, Corpus Christianorum: Continuatio Mediaevalis, 181 (Turnhout: Brepols, 2002), 13-52.

61 On Raymond of Sabunde's apologetics, see Walter Andreas Euler, "Raimund von Sabunde," Theologische Realenzyklopädie 28 (1997): 122-125.

62 E.g., Jürgen Habermas, "Ein Bewußtsein von dem, was fehlt," in Ein Bewußtsein von dem, was fehlt: Eine Diskussion mit Jürgen Habermas, ed. Michael Reder and Josef Schmidt (Frankfurt: Suhrkamp, 2008), 26-36. However, it is hard to see why a secular society ought to be necessarily postmetaphysical, as Habermas states (33).

63 Boethius, De Trinitate 5 in Boethius, The Theological Tractates, ed. and trans. H. F. Stewart and E. K. Rand, The Loeb Classical Library (London: Heinemann., 1918), 26-27.

64 De pace fidei 8 , n. 23. 


\section{Why Naming the Trinitarian God is Still Important for Cusa}

This translation of kerygmatic proper names into philosophical concepts should not, however, be misunderstood as a reduction of proper names to definite descriptions, as is done by Russell. ${ }^{65}$ Proper names are constitutive for interpersonal communication, revelation, and religious practice. Contrary to conceiving something, naming someone means getting familiar with him or her. In one of his main theological works, Introduction to Christianity, Joseph Ratzinger points out the difference between a mere philosophical concept of God that points at God's essence, and a name of God that is relevant for religious life, as the latter enables an interpersonal communication with God. ${ }^{66}$ Already in his first lecture held at the University of Bonn in 1959, Ratzinger states that God's accessibility (Ansprechbarkeit) in prayer is one of the most important innovations of monotheism compared to polytheism. ${ }^{67}$ In doing so, he differentiates between the meaning of personality in metaphysics and in philosophy of religion. In terms of metaphysics, even Aristotle's unmoved mover can be called personal, due to his self-reference or self-reflection. However, in terms of philosophy of religion, personality must entail accessibility. 68

Nicholas of Cusa shares both meanings of personality. On the one hand, God is absolutely self-referential. At the same time, God's accessibility is also central to Cusa's thought, testified by many passages ${ }^{69}$ and by the mystagogical framework of his entire oeuvre.

Above all, there always remains a gap between God's First-Person-Speech in revelation, the Second-Person-Speech in prayer, and the Third-Person-Speech in philosophy or theology.

In his book In Excess, Jean-Luc Marion refers to the Jewish tradition of the ineffable name of God, which can never be pronounced as a proper name. ${ }^{70}$

65 On Russell's description theory, see his article "On Denoting," Mind 14/4 (1905): 479-493.

66 Joseph Ratzinger, Einführung in das Christentum: Vorlesungen über das Apostolische Glaubensbekenntnis, 4th ed. (Munich: Kösel, 2005), 122-123.

67 Joseph Ratzinger, Der Gott des Glaubens und der Gott der Philosophen: Ein Beitrag zum Problem der theologia naturalis, ed. Heino Sonnemanns, 3rd ed. (Trier: Paulinus, 2006), pp. 27-28.

68 Ibid., 63, note 7 .

69 E.g., De docta ign. I, 26; III, Prol.; III, 12; De vis. Dei 4 (h VI n. 9)—25 (h VI n. 119); Sermo XXIII (h XVI, 4 n. 37).

70 Jean-Luc Marion, In Excess: Studies of Saturated Phenomena, trans. R. Horner and V. Berraud, Perspectives in Continental Philosophy, 27 (New York: Fordham University Press, 2001), 157 . 
But even in Christianity, this apophatic tradition is still present and deploys a religious transformation of human beings:

For the name no longer functions by inscribing God within the theoretical horizon of our predication but rather by inscribing us, according to a radically new praxis, in the very horizon of God. This is exactly what baptism accomplishes when, far from our attributing to God a name that is intelligible to us, we enter into God's unpronounceable Name, with the additional result that we receive our own. This pragmatic theology is deployed, in fact, under the figure of the liturgy (which begins with baptism), where it is never a matter of speaking of God, but always of speaking to God in the words of the Word. ${ }^{71}$

According to Marion, the essence of Christian theology does not consist in talking theoretically of God, but in talking to God in worship. Since worship presupposes a certain accessibility of God, God must render himself accessible by revealing himself to mankind. Here we must be aware of an important difference between man and God. Human beings always reveal themselves after having been named by someone else, for example parents who choose a certain name and start talking with their child. After some time of getting familiar with words, it is the child who reveals him- or herself as a person by calling or conversing with his or her parents. ${ }^{72}$ God, in contrast, does not need to be named or called by human beings in order to reveal himself as personal. As the trinitarian formula "non aliud est non aliud quam non aliud"73 indicates, it is God who names himself. Although God's proper name, which enfolds the essence of all beings, is absolutely transcendent, ${ }^{74}$ it becomes visible in our contingent world through Jesus Christ, God incarnate. In fact, for Cusa, Jesus is God's proper name. ${ }^{75}$ As universal mediator, he connects divinity and humanity, or, more precisely, he enables the human image to be part of its divine exemplar without being absorbed by it. ${ }^{76}$

\footnotetext{
71 Ibid., 157 .

72 An interesting phenomenological investigation on the correlation between revelation and personality is given in August Brunner, Offenbarung und Glaube: Eine phänomenologische Untersuchung (Munich: Berchmans, 1985), 11-28.

73 De non aliud 1.

74 De docta ign. I, 24.

75 Sermo XXIII, n. 28-40.

76 De vis. Dei 18, n. 82.
} 
So we can draw the conclusion that Cusa's trinitarian theology finally boils down to a Christology aiming at guiding humans-including people from other religions - to the heart of the Trinity. ${ }^{77}$ In doing so, he differs significantly from contemporary Christian-Muslim dialogue, which excludes proselytism as well as syncretism. Nevertheless, Cusa still shares the Muslim concern about God's unity. Therefore, the Islamic rejection of the trinitarian doctrine plays a key role in Cusa's trinitarian speculation. On the one hand, it serves as a starting point for Cusa's rational apologetic of the Trinity, meant as a response to Qur'anic objections. On the other hand, it helps him to deepen and purify his own trinitarian belief, separating it from popular, especially tritheistic, misunderstandings. In this way, contemporary trinitarian theology could learn a lot from Cusa's awareness that the trinitarian doctrine is still monotheistic. But also, contemporary interreligious dialogue could be reminded that both Christianity and Islam entail an alethic dimension.

77 On the mystical dimension of Cusa's trinitarian speculation see Bernard McGinn, "Unitrinum seu triunum: Nicholas of Cusa's Trinitarian Mysticism," in Mystics: Presence and Aporia, ed. Michael Kessler (Chicago: University of Chicago Press, 2003), 90-117. 
PART 2

Historical Perspectives 



\title{
Deficient Sacraments or Unifying Rites? Alan of Lille, Nicholas of Cusa, and Riccoldo da Montecroce on Muslim and Jewish Praxis
}

\author{
Rita George-Tvrtković
}

Baptismal washings occur among both Hebrews and Arabs; [accordingly,] it will not be difficult for them to accept for their profession of faith the washing instituted by Christ. They will quite readily consent to their children being baptized. ${ }^{1}$

Nicholas of Cusa (d. 1464) was not the only medieval Christian to mention quasi-baptismal washings such as Muslim wudu and Jewish mikveh in his discussion of non-Christian religions. In fact, most medieval theologians concentrated their critique of 'infidel' rites on the same few practices: ablution, circumcision, abstinence from pork or wine, polygyny, and the literal interpretation of scripture. However, Nicholas's perspective here is unique. His glib suggestion-that wudu and mikveh are so similar to Christian baptism that Muslims and Jews would 'quite readily' accept it - is striking for its optimism (and naiveté). Furthermore, Nicholas's relatively positive view can be contrasted with the more commonly held negative views of theologians like Alan of Lille (d. 1202/3), who condemned wudu as a deficient sacrament, and Islam itself as a 'monstrous sect.'

Alan and Nicholas might seem to have divergent views of Muslim and Jewish praxis, but they are actually more similar than they first appear. Alan understood non-Christian rites in a pessimistic way, seeing only their ability to divide. Nicholas, on the other hand, understood non-Christian rites in an optimistic way, seeing only their ability to unify. But in both cases, the theologian was unable to appreciate or even articulate the particularities of these

1 Nicholas of Cusa, De pace fidei in Nicholas of Cusa's De Pace Fidei and Cribratio Alkorani: Translation and Analysis, trans. Jasper Hopkins, 2nd ed. (Minneapolis: Arthur J. Banning, 1994), 67. Critical Latin text of De pace fidei can be found in Raymond Klibansky and Hildebrand Bascour, eds., Nicolai de Cusa Opera Omnia, vol. 7 (Hamburg: Meiner, 1959); here, XVII.61. All citations of De pace in this essay will refer both to the Latin edition (chapter and paragraph number), and to Hopkins's English translation (page number). 
non-Christian practices, and instead simply dismissed them-either negatively like Alan (who deemed the rites deficient) or positively like Nicholas (who believed the rites could be easily transformed). Luckily, the reductionism of Nicholas and Alan does not exhaust medieval perspectives on non-Christian rites. A few other theologians, including the Dominican Riccoldo da Montecroce (d.1320), offer a more nuanced but also more ambivalent approach. In Riccoldo's case, this complexity is no doubt partly due to the fact that he lived in Baghdad for over a decade and witnessed Muslim praxis firsthand, unlike Nicholas and Alan who never set foot outside Christendom, as far as we know. Among these three authors, Riccoldo alone takes non-Christian rites seriously, at least in the case of Islam, for he describes Muslim praxis in great detail and with relative accuracy. In a few places he even praises Muslim praxis; this is also true for his descriptions of Eastern Christian and Tartar (Mongol) rites, which he also claims to have observed during his Middle Eastern travels. Interestingly, Riccoldo's descriptions of Muslim rites stand in marked contrast to his discussion of Jewish rites, which out of all the religions he discusses in his books is the least detailed and nuanced.

Alan, Riccoldo, and Nicholas were born in different centuries, came from distinct cultural contexts, and had varying levels of familiarity with nonChristian practices and doctrines. In light of these differences, this article will spotlight what each wrote about both Muslim and Jewish praxis, with an eye to 1) differences in the way the same author treated Muslim versus Jewish praxis, and 2) differences among the three authors in their overall approach to other religions. The three theologians are similar in that they all place their discussion of Muslim and Jewish praxis within an overall hierarchy of religions, stressing relationships among them and providing an implicit Christian theology of religions. Nevertheless, they differ in their conclusions, thus offering us a glimpse at the wide range of medieval Christian views on Muslim and Jewish praxis: from deficient sacraments (Alan), to unifying rites (Nicholas), to practices sometimes even worthy of praise (Riccoldo).

\section{Hierarchy of Religions}

Before turning to an analysis of the texts, a brief word must be said about their structure. Alan of Lille's Quadripartita editio (c. 1185), also known as De fide catholica contra haereticos, Valdenses, Iudaeos, et paganos, is an apologetic handbook meant to help preachers combat various threats to orthodoxy. ${ }^{2}$ Its

2 The Latin text of De fide can be found in Marie-Thérèse d'Alverny, ed., Alain de Lille: Textes Inédits (Paris: Vrin, 1965), as well as in PL 210: 305-430. See also Marie-Thérèse d'Alverny's 
four parts are organized hierarchically: the first two books treat the groups closest to the Roman Church, the heretical Cathars and Waldensians, respectively; the third book treats Jews; and the last book treats pagans, by which Alan means Muslims (he also calls them Saracens and Mahometans, though interestingly he does not call them heretics, as Peter the Venerable and others did before him). ${ }^{3}$ Riccoldo arranges the sections of his missionary handbook, Ad nationes orientales (c. 1300), in roughly the same order as Alan: his first chapter discusses what he calls the heretical Jacobites and Nestorians, his second chapter discusses Jews, and his third chapter discusses Saracens, whom he- unlike Alan-distinguishes from pagans. ${ }^{4}$ The fourth and last chapter discusses Tartars (Mongols). ${ }^{5}$

One can detect this very same hierarchy of religions nearly one hundred and fifty years later in Nicholas of Cusa's De pace fidei (1453), although the hierarchy is reversed and the order is not strictly followed. De pace's dialogue between seventeen different nations begins with the group ostensibly most distant from Christianity, thus: first pagan philosophers discuss wisdom; then an Indian (Hindu) discusses idolatry; then Chaldeans, Jews, and Persians discuss

critical Latin edition and introduction in "Alain de Lille et l'Islam, Le Contra Paganos," Cahiers de Fanjeaux 18 (1983): 301-350. For more on De fide and a general introduction to Alan of Lille, see Gillian Evans, Alan of Lille: The Frontiers of Theology in the Later Twelfth Century (Cambridge: Cambridge University Press, 1983).

3 Terms such as 'pagan,' 'gentile,' and 'infidel' retained a certain fluidity throughout the medieval era. See Yves Congar, “'Gentilis' et 'Iudaeus' au moyen âge," Recherches de théologie ancienne et médiévale 36 (1969): 222-225. Congar argues that the gentile cannot simply be equated with Jews; he points to Alan of Lille's four categories and to the distinction made by Aquinas and others between gentiles and Jews. (Aquinas lists three kinds of disbelief in ST II.II.10.5-11.) For more on the ambiguous identity of the gentile in Alan of Lille, see Evans, Alan of Lille, 128-29. For more on the ambiguous identity of the gentile in Aquinas, see the article by Mark Jordan, "The Protreptic Structure of the Summa contra Gentiles," The Thomist 50 (1986): 173-209.

4 There is no critical Latin edition of Riccoldo's Ad nationes orientales, which exists in three medieval Mss, including one in the author's own hand at Biblioteca Nazionale Fiorenze (MS Conv. Sopp. C. 8. 1173, fols. 21r-244r). Dondaine has published only excerpts in "Ricoldiana: notes sur les œuvres de Riccoldo de Montecroce," Archivum Fratrum Praedicatorum 37 (1967): 119-70. Kurt Villads Jensen formerly posted the entire Latin text online but has since removed it. All English translations in this paper are my own (translated from the Jensen version).

5 Interestingly, Riccoldo offers another (reversed) hierarchy in the prologue of Ad nationes. Here, he places the Tartars (Mongols) first because he believes religions that are doctrinally the most distant from Latin Christianity are also the easiest to convert, while those who are doctrinally closest, such as the Jacobites, are placed last, because they are most difficult to convert: "Experience shows that the Tartars are easier to convert than the Saracens, the Saracens easier to convert than the Jews, and the Jews easier than the [Eastern] Christians." 
the Trinity and Incarnation; and finally, Armenians, English, and Bohemians discuss the sacraments. In general, Nicholas sticks to the hierarchy despite several anomalies, ${ }^{6}$ and the overall movement of the discussion goes from truths obtained by reason (e.g., the existence of truth and the one God), to articles of faith obtained by revelation (e.g., the Trinity and Incarnation), to issues of ritual diversity (e.g., circumcision and the Eucharist).

In short, Alan, Riccoldo, and Nicholas all use the same hierarchy of religions to structure their writings, where the hierarchy is based on each religion's perceived proximity to or distance from the Roman Church. But similar structure does not necessarily generate similar content, for in the end, each theologian reaches a vastly different conclusion about 'infidel' rites.

\section{Alan of Lille: Deficient Sacraments}

Alan of Lille (d. 1202/3) was a Cistercian master who taught at Chartres and Paris, but also preached against the Cathars while living in Montpellier. He aimed to provide a comprehensive view of all non-orthodox groups in his book De fide catholica, as a way to combat heresy. This goal is not surprising when taking into account when and where Alan was writing; scholars date his text to circa 1185, just a year after the Council of Verona's condemnation of the Waldensians, one of the heretical groups targeted by Alan in his book. ${ }^{7}$ Alan's emphasis on Christian errors over Jewish and Muslim ones can be inferred simply by the amount of ink he spilled on each group; the section on Cathars contains seventy-six chapters, while the section on Jews has only twenty-one and the one on pagans (Muslims) has even less at fifteen. In the first section of the work, Alan focuses his discussion on the seven sacraments, which also makes sense given his Cathar target. A discussion of Jewish and Muslim rites, albeit far from comprehensive, is featured in the other sections as well.

Because Alan had spent time in southern France, much of his information on Cathar and Waldensian doctrine and practice was probably obtained firsthand. However, his information on Jews and Judaism most likely was not. There is evidence that he learned about Judaism mainly from Gilbert Crispin's late eleventh-century Disputatio Judaei et Christiani, a text that seems to have been based on a real conversation. ${ }^{8}$ David Berger observes that roughly forty

6 The Tartars (Mongols) are not presented with the Indians as one might think, and the Turks are tossed in with Spanish and German Christians.

7 Evans, Alan of Lille, 104.

8 David Berger, "Gilbert Crispin, Alan of Lille, and Jacob ben Reuben: A Study in the Transmission of Medieval Polemic," Speculum 49/1 (1974): 34-47. 
percent of Alan's chapter on the Jews in De fide is copied nearly verbatim from Crispin, ${ }^{9}$ while Jeremy Cohen notes that Alan's writings "contain no evidence of any personal familiarity with rabbinic literature."10 As for Alan's chapter on Islam, it is unclear whether he had access to the most up-to-date information available in Northern Europe at the time, which would have included either Peter the Venerable's Summa totius haeresis Saracenorum (a primer on Islam written for Christians), or the so-called Toledan Collection (a compendium of Islamic primary texts Peter had had translated into Latin in the mid twelfth century, which included the first Latin translation of the Quran by Robert of Ketton). ${ }^{11}$ If Alan did consult Peter's Summa or the Toledan Collection, there is scant evidence of it in Contra paganos. ${ }^{12}$

In fact, Alan's short sections on Jewish and Muslim doctrine and practice contain very little originality, except in terms of their organization (some scholars believe it is organized like a handbook for quick reference by preachers) ${ }^{13}$ For example, in his section on Islam, Alan mentions the very same rites that almost every medieval Christian mentions when writing on Islamic practice: wudu (ablution), prayer, fasting, almsgiving, the prohibition of wine and pork, and circumcision. From these, the Muslim ritual of wudu was especially popular among Christians due to its seeming similarity to baptism. ${ }^{14}$ And indeed, two entire chapters of Alan's Contra paganos (which contains only fifteen chapters, as noted above) are devoted to wudu. Since Alan most likely

Berger, "Gilbert Crispin," 34. Berger argues that some of the same passages from Crispin that were copied by Alan were also translated into Hebrew by Jacob ben Reuben in his Wars of the Lord; it is possible that both Jacob and Alan consulted a collection of polemical texts circulating in northern France at the end of the twelfth century that included substantial material from Crispin, 37.

10 Jeremy Cohen, Living Letters of the Law (Berkeley: University of California, 1999), 309.

11 For more on the Toledan collection, see the classic article by Marie-Thérèse d'Alverny, "Deux traductions latines du Coran au Môyen Age," Archives d'histoire doctrinale et litteraire du môyen age 16 (1948): 69-131. For a more recent treatment, see José Martínez Gázquez, "Translations of the Qur’an and Other Islamic Texts before Dante (Twelfth and Thirteenth Centuries)," Dante Studies 125 (2007): 79-92.

12 d'Alverny, "Alain de Lille et l'Islam," 305.

13 Evans, Alan of Lille, 117.

14 One example of the widespread medieval interest in wudu can be seen in a manuscript of Riccoldo's Liber peregrinationis (MS Vatican Library, Barberini, Lat. 2687, f. 1r-12v), where several later annotators had underlined Riccoldo's entire discussion of wudu. For the critical Latin edition of Liber peregrinationis (hereafter LP), see René Kappler, ed., Pérégrinationes et Letters (Paris: Honoré Champion, 1997). An English translation of LP can be found in Rita George-Tvrtković, A Christian Pilgrim in Medieval Iraq: Riccoldo da Montecroce's Encounter with Islam (Turnhout: Brepols, 2012). All page references to LP in this article are to the English translation by George-Tvrtković, unless otherwise noted. 
never witnessed an actual Muslim performing this ritual, it is not surprising that he does not describe it in any detail. Rather, he focuses on intentionality, form, and efficacy, with the primary question: is the Muslim 'ablutio corporis per aquam' sufficient for the remission of sins? Alan concludes-without providing any concrete details about Muslim ablution at all—that wudu is insufficient for the remission of sins because it is merely an external washing, with no internal contrition involved. ${ }^{15}$ Alan's critique is therefore focused on the superficiality of the external act, which he believes has no interior component. This parallels his critique of Muslim heaven, which he likewise condemns as entirely carnal because he believes that Muslims interpret the Qur'anic description of heaven literally, never allegorically. ${ }^{16}$ Alan's focus on the relationship between the internal and external aspects of Muslim rites makes sense given his overall argument against heresy, especially against the Cathars, who argued for the spiritual inefficacy of sacraments, which they deemed purely physical in nature. ${ }^{17}$

Moreover, Alan not only criticizes the intentionality or inner reality of Muslim wudu, he also criticizes its outward form. In Alan's view, there are at least two problems with the form of wudu: it does not invoke the Trinitarian formula, and it can be repeated. Here too, Alan explicitly parallels the repetitive nature of Muslim wudu with the kind of rebaptism practiced by some heretics. ${ }^{18}$ In short, Alan deems Muslim wudu as a deficient baptism in every sense, from its inner reality to its outward form. And if that were not enough, Alan ends his chapters on wudu with one last criticism: he accuses Muslims of 'Judaizing,' not only in wudu but also in other practices, such as when they abstain from pork or take multiple wives. ${ }^{19}$ In Alan's eyes, Jewish and Muslim rituals are equally ineffective and are both forms of idolatry, primarily because they are rooted in an overly literal interpretation of the Law of Moses. ${ }^{20}$

Alan had meant for his Contra paganos on Muslims (Book Four of De fide) to be read in tandem with Contra Iudaeos (Book Three), since his argument for the Trinity in Book Four consists simply of a short reference to what had already been stated in Book Three. ${ }^{21}$ Likewise, what he writes about Jewish

15 Contra paganos (Ch. 9), 342. All page references are to the critical Latin edition of Contra paganos, edited by d'Alverny.

16 Contra paganos (Ch. 5-6), 338-39.

17 Evans, Alan of Lille, 105.

18 Contra paganos (Ch. 10), 343.

19 Contra paganos, (Ch. 10), 343.

20 Contra paganos, (Ch. 10), 343.

21 Contra paganos, (Ch. 1), 332: "Ad quos confuntandos que contra iudeos de unitate et trinitate diximus dicta sufficiant." 
practice in Book Three is connected to what he later says about Muslim practice in Book Four. In both cases, he condemns Jews and Muslims for their literal interpretation of the Law. He thus criticizes the Jewish abstinence from pork as unnecessary in Chapter Eight (this is one of the sections he copied from Gilbert Crispin), ${ }^{22}$ while in Chapter Ten he connects Jewish rituals to a literal interpretation of the Law, which he calls a kind of 'death' (this section is original to Alan). He argues for the abandonment of all such rituals by citing history, claiming that there have been times in the past when Jews themselves have changed their observance of the Law of Moses. And since now there is no longer any sacrifice, priests, prophets, temple, or places of sacrifice, ${ }^{23}$ Alan concludes that Jewish practices such as abstaining from pork can likewise also be abandoned, as Christians already know.

\section{Nicholas of Cusa: Unifying Rites}

We will now jump ahead two centuries to Nicholas of Cusa's De pace fidei, a short tract written explicitly as a response to the fall of Constantinople in 1453. De pace is presented as a heavenly 'dialogue' between the members of seventeen different religious groups, including Jews and Muslims. It is important to note that Nicholas studied Islam and the Qur'an later in life (his 'sifting' of the Qur'an, Cribratio Alkorani, appeared in 1461), but his knowledge of Judaism in 1453 remains unclear. He never wrote a text devoted entirely to Judaism, and only refers to the religion in passing in just a few places, including: two sermons on God's name, legislation regarding Jewish dress in the German diocese of Minden, and a few short passages in De pace. ${ }^{24}$

The goal in writing De pace, says Nicholas, is to prevent global religious violence by convincing all religions to agree that there is only "one religion in a variety of rites." 25 To reach such an agreement, however, the dialogue partners must first grapple with their diverse doctrines and practices. With respect to praxis, Christian sacraments are discussed alongside non-Christian practices

\footnotetext{
22 Berger, "Gilbert Crispin," 34.

23 Contra Iudaeos, Chapter 10, PL 201:410.

24 Thomas Izbicki, "Nicholas of Cusa and the Jews," in Conflict and Reconciliation: Perspectives on Nicholas of Cusa, ed. Inigo Bocken (Leiden: Brill, 2004), 119-130. Sections of De pace that mention Judaism: IX.25-26; XII.41; XIII.42, 44; XV.53; XVI.54-55, 59; XVII.62. (Hopkins's corresponding page numbers: $46-47,55-56,62-63,65,67$.)

25 De pace I.6 (Hopkins, 35): "Non est nisi religio una in rituum varietate." For more on this phrase (about which scholars have debated for years), see the essay by Wilhelmus Valkenberg in this volume.
} 
such as circumcision and the 'baptismal washings,' as mentioned in the quote at the beginning of this essay. Like Alan, Nicholas sees parallels between Muslim wudu and Christian baptism, though Nicholas also adds Jewish washings to the mix. However, unlike Alan, who deems wudu unsatisfactory, Nicholas instead suggests that Jewish and Muslim 'washings' are similar to baptism. ${ }^{26}$ For Nicholas, the mere presence of baptism-like ablutions among Jews and Muslims is yet another proof that the 'same one religion' underlies different rites:

For baptism is nothing other than a confession of that faith [in Christ] by means of a sacramental sign ... Baptismal washings occur among both Hebrews and Arabs; [accordingly,] it will not be difficult for them to accept for their profession of faith the washing instituted by Christ. ${ }^{27}$

What is more, Nicholas believes that the rite of baptism could even be used to unify the members of various religions. This belief is evident in the following amazing assertion:

[Hebrews and Arabs] will quite readily consent to their children being baptized. Since for religious reasons they have allowed males to be circumcised on the eighth day, then the transformation of circumcision to baptism will be acceptable to them, and a choice will be given to them as to whether or not they wish to be content with baptism alone. ${ }^{28}$

Of course, Nicholas thought that the rite of baptism would unify the various religions because he believed that baptism is rooted in a single faith, and that single faith, furthermore, 'presupposes Christ' (a point he repeats numerous times throughout De pace).

In some ways Nicholas's approach to non-Christian rites is the exact opposite of Alan's, but in other ways, it is indeed quite similar. While Alan is too quick to reject Muslim and Jewish rituals as deficient sacraments, thus proving that these religions are not de fide catholica, Nicholas seems too quick to accept the rites as a means to interreligious unity. In several places throughout De pace, Nicholas states how easy it will be to get a certain group to agree to a modification of practice. Two examples will suffice. First, as noted above, Nicholas

\footnotetext{
26 De pace, XVII.61 (Hopkins, 67).

27 De pace, XVII.61-62 (Hopkins, 67).

28 De pace, XVII.62 (Hopkins, 67).
} 
asserts that "washings occur for religious devotion among the Hebrews and Arabs" therefore "it will not be difficult for them to accept the washing instituted by Christ" and "they will quite readily consent to their children being baptized."29 Second, and even more interestingly, Nicholas seems to be open not only to a modification of Jewish or Muslim practice (how generous of him!), but at one point even expresses a willingness to modify Christian practice. He supports this by noting the presence of ritual diversity between Eastern and Western Christians, acknowledging the fact that 'Ethiopian Jacobites' (Ethiopian Orthodox Christians) even practice circumcision. ${ }^{30}$ He then goes on to make a surprising suggestion (given traditional Christian concerns about Judaizing), proposing that all Christians should be willing to get circumcised, if such a concession would preserve peace among the religions: "Indeed, if for the sake of peace the majority were to conform itself to the minority and to receive circumcision, then I would deem that this should be done, in order that in this way peace might be established."31 It seems that for Nicholas, at least in De pace fidei, peace among the nations is at least as important as doctrinal orthodoxy, and certainly more important than ritual agreement. ${ }^{32}$

\section{Riccoldo da Montecroce: Ambivalence}

Riccoldo da Montecroce (d. 1320) was a Florentine Dominican who lived for over ten years in Baghdad, where he studied Islam and Arabic with Muslim masters in their schools, mosques, and homes. Riccoldo's writings on other religions-which include not only the missionary handbook Ad nationes orientales, but also his Liber peregrinationis, Contra legem Sarracenorum, and Epistolae ad ecclesiam triumphantem-are replete with descriptions of

29 De pace, XVII.61 (Hopkins, 67). Emphasis mine.

30 De pace, XVI.6o (Hopkins, 66).

31 De pace, XVI.6o (Hopkins, 66). When writing this section, Nicholas surely had in mind the discussions about circumcision that took place between Latin and Coptic Christians at the Council of Ferrara-Florence (1438). While the Council eventually came down on the side of non-accommodation, this section of De pace suggests that Nicholas disagreed with the Council's decision. I am grateful to Dr. Walter Andreas Euler for bringing this point to my attention at the American Cusanus Society conference at Gettysburg in October 2012.

32 Nicholas's involvement in efforts to reunite Eastern and Western Christians must not be forgotten. In the fall of 1437 , he even visited Constantinople as part of a papal delegation to the Greeks-all in preparation for the so-called 'reunification council' at FerraraFlorence the following year. Like Alan, Nicholas's opinions about the rites and doctrines of other Christians and non-Christian religions are connected. 
his personal experiences of Muslims (as well as of Eastern Christians and Tartars). ${ }^{33}$ Of all the religions he describes, he says the least about Judaism, even though he does write a lengthy section about it in Ad nationes, and elsewhere mentions that he witnessed a debate in a synagogue between Dominicans and the large community of Jews in Mosul, Iraq. ${ }^{34}$ While Riccoldo boasts repeatedly about his knowledge of Arabic (including several Arabic terms and even adding a few words in Arabic script in one manuscript), his knowledge of Hebrew is unknown but probably nil, as there is no evidence for it in his writings. ${ }^{35}$

Riccoldo writes a great deal about Muslim praxis; in fact, it could be proposed that he writes more about it than any other medieval Christian author. ${ }^{36}$ In Liber peregrinationis, he devotes an entire section to the description and praise of seven Muslim practices that he calls 'works of perfection,' which consist of: prayer, almsgiving, devotion to study, respect for God's name, strictness of morals, hospitality to strangers, and fraternal love. ${ }^{37}$ Three aspects of Riccoldo's discussion of Muslim praxis are noteworthy. First, he describes Muslim practices mentioned by no other medieval Christian (such as their reverence for the name of God). Second, some of these details could not have

33 For the critical Latin edition of Epistolae ad ecclesiam triumphantem (hereafter Epistolae), see Reinhold Röhricht, "Lettres de R. de Monte-Cruce," Archives de l'Orient Latin 2 (1884): 258-269. The English translation of Epistolae, to which I will be referring in this essay, can be found in George-Tvrtković, A Christian Pilgrim in Medieval Iraq. For the critical Latin edition of Contra legem Sarracenorum (hereafter Contra legem) see Jean-Marie Mérigoux, "L'ouvrage d'un frère prêcheur en Orient à la fin du XIII ${ }^{\mathrm{e}}$ s., suivi de l'édition du Contra legem Sarracenorum," Memorie Domenicane XVII (1986): 1-142.

34 LP, 200.

35 George-Tvrtković, A Christian Pilgrim in Medieval Iraq, 24-25.

36 William of Tripoli is a close second, both in terms of accuracy of description and substantive commentary. See Peter Engels, ed. and trans., Wilhelm von Tripolis: Notitia de Machometo (Würzburg: Echter, 1992), especially 256-57. Yet, Riccoldo still writes more pages and a more sustained commentary on Islamic praxis than William. For more on William of Tripoli, see Thomas O'Meara, "The Theology and Times of William of Tripoli: A Different View of Islam," Theological Studies, 69 (2008): 80-98. Petrus Alfonsi also writes on Muslim praxis throughout the fifth part of Dialogi, but his descriptions are short and perfunctory, with little commentary.

37 It is interesting that Riccoldo omits fasting from this list, for almost all other Christians, whether medieval or modern, are quick to acknowledge the triumvirate of fasting, prayer, and almsgiving. Petrus Alfonsi lists all five pillars of Islam, including prayer, fasting, and almsgiving. Roger Bacon and Ramon Martí also mention all three. Fasting, prayer, and almsgiving are the only Muslim practices specifically mentioned in the 1965 Second Vatican Council document Nostra Aetate. 
been gleaned simply from reading Islamic literature (for example, the looks on the faces of Muslims while praying), and instead, they seem to be the result of his personal observation of actual praxis. And thirdly, Riccoldo not only describes Islamic praxis, but he actually praises it, and his praise is explicit and sustained. Riccoldo's praise is such that not only does he claim that Muslims are equal to Christians in some of their practices (e.g., hospitality), but furthermore, he maintains that Muslims even surpass Christians in some cases (e.g., forgiveness). No other medieval theologian is as complimentary about Muslim praxis as Riccoldo. ${ }^{38}$

Of the seven works of perfection, there are five works that I have never seen mentioned by any other medieval Christian that I know of. They are: devotion to study, hospitality, reverence for the name of God, mutual concord among Muslims, and solemn demeanor. Here I will briefly describe two of them: devotion to prayer and reverence for the name of God.

\section{Devotio in oratio}

Riccoldo begins this section by admitting to his readers that Muslim devotion to prayer is so great that it 'stupefied' (obstupuimus) him. ${ }^{39}$ He had already expressed the same sentiment earlier, when describing his surprise at the very existence of the seven works of perfection among the Saracens. In this section, he says that his amazement is the result of his experience (per experientiam) seeing Muslims pray daily. Furthermore, this firsthand experience enables him to describe the various types of comportment he has seen among Muslims in prayer: some swoon or their faces drain of all color, while others dance, change their voice, or shake their heads. Some seem to be in ecstasy, while others appear possessed by demons. ${ }^{40}$

The remainder of Riccoldo's discussion of prayer (which amounts to half of the section) is devoted to wudu. He lists which body parts are washed, and in what order: first private parts, then hands, then face, and lastly the soles of

38 William of Tripoli includes a long description of prayer in the mosque, but his account includes only several short compliments interspersed throughout, not sustained praise. See his Notitia, especially $25^{6-58 .}$

39 LP, 212. For an expanded discussion of the works of perfection, see George-Tvrtković, A Christian Pilgrim.

40 LP, 212. Riccoldo seems to be describing Sufi prayer practices here, rather than the highly ritualized daily salat. This is different than other medieval Christians who mention Muslim prayer such as Petrus Alfonsi, who merely note that Muslims pray five times a day, or that prayer is preceded by ablutions (both facts can be found in the Qur'an). 
the feet. ${ }^{41}$ Riccoldo notes that this practice is "observed by all the sects" and then offers specific details about Hanafi wudu, which he claims is "reputed to be more perfect than the others." 42 As proof of Hanafi fastidiousness, Riccoldo reports that if they touch a cat, dog, or donkey, they must bathe in at least fifteen hundred buckets of water (for this reason they usually wash in a river). They are so scrupulous, claims Riccoldo, that even after bathing in a river, they place a finger in the anus and smell it to confirm their cleanliness. ${ }^{43}$

Riccoldo's emphasis on Muslim comportment during prayer, as well as on the ablution which precedes it, indicates his focus on the physical aspects of Muslim prayer. Riccoldo does not tell us what Muslims say when they pray, nor does he venture into intentionality. ${ }^{44}$ So even though Riccoldo includes unique details regarding Sufi prayer postures and the particularities of Hanafi $w u d u$, in the end his description of Muslim prayer is nearly as superficial as that of Petrus Alfonsi, who also lists all the body parts washed during wudu. However, Riccoldo's description of prayer still remains significant due to its overall complimentary tone. Unlike Alan of Lille, who considers wudu a deficient form of baptism, Riccoldo regards it as a key part of Muslim prayer, which he calls a 'work of perfection.'

\section{Reuerentia ad nomen Dei}

As proof of the great reverence Muslims have for the name of God, Riccoldo begins by describing their practice of saying or writing the basmala-before beginning any letter, speech, trip, or other important act—in order to demonstrate that all is done in God's name.${ }^{45}$ Riccoldo's description of the basmala is accurate and sympathetic:

\footnotetext{
$41 \quad$ LP, 212.

42 The Hanafi, along with the Shafii, Hanbali, and Maliki, comprise the four traditional Muslim schools of jurisprudence.

43 LP, 212.

44 Only William of Tripoli speculates about Muslim intentionality: "In so doing [praying], amazingly, I think, they please God and men, if they have true faith," Notitia, 258. Evidently, William is as amazed as Riccoldo at how devoted Muslims are to prayer.

Basmala is derived from the first word in the phrase, bismillah ar-rahman ar-rahim, which means, "In the name of God, the merciful, the compassionate." The basmala is the very first line of the Qur'an, and can be found before every Sura of the Qur'an except the ninth. It is the most oft-recited prayer in Islam, said during all five daily prayers and many other times during the day.
} 
They take the greatest care in never doing, saying, or writing anything of importance without first beginning with the name of God. Also in all the letters they send, they first write reverently the name of the Lord and therefore diligently take care to avoid destroying or throwing away any writing. If they find a piece of paper covered with writing, they reverently pick it up and place it up high in the wall, lest the name of the Lord be trampled underfoot. ${ }^{46}$

Riccoldo is highly complimentary here; note that he repeatedly describes Muslims as acting with care, diligence, and reverence. As additional proof of Muslim reverence for God's name, Riccoldo describes another quintessentially Islamic custom: the salawat. This is the adding of praises such as 'glorified and exalted is he' after mentioning the name of Allah, or 'peace be upon him' after saying the name of one of the prophets: "When they come across the name of the Lord while reading or speaking, never does anyone say it alone, but they always add a praise like, 'God who is praised,' or something of this nature." ${ }^{37}$

The fact that Riccoldo includes 'reverence for the name of God' in his list of Muslim good works is significant. Unlike the other Muslim practices he mentions (e.g., prayer and almsgiving), which he recognizes and praises in Islam in part because they are Christian works already familiar to him, in this section he highlights a practice that finds no easy counterpart in Christianity. Furthermore, Riccoldo's description of the basmala demonstrates a sound understanding of Islamic theology. Thus, when listing the seven Muslim works of perfection, Riccoldo is careful to entitle this particular virtue 'reverence for the name of God,' and not merely 'reverence for God,' demonstrating that he knew the basmala reflects Islam's particular focus on the name of God itself. 48

However, Riccoldo's descriptions of Muslim praxis elsewhere are less than complimentary. For example, in another book, Riccoldo ridicules how and why - and even questions whether-Muslims fast. ${ }^{49}$ Elsewhere he criticizes the Qur'an for recommending fasting and almsgiving as means to repent for

\footnotetext{
$46 \quad$ LP, 213.

47 LP, 213.

48 Cf. Suras 7:180, 17:110, 20:8, 59:24, where some of the names of God are listed. The hadiths elaborate on this concept, and refer to God's 'ninety-nine names.'

49 Contra legem, 142.
} 
one's sins, suggesting that this encourages Muslims to sin. ${ }^{50}$ This criticism is especially strange, given that fasting and prayer are similarly important for Christians.

Riccoldo is clearly ambivalent about Muslim praxis. In his Contra legem he concedes that the Qur'an "contains works difficult to implement, like circumcision, not drinking wine, avoiding inebriation, fasting, praying, and giving according to one's means. ${ }^{51}$ However, he immediately mitigates this concession by adding that it does not really matter what the Quran says, since according to his experience, Muslims do not observe it anyway:

Yet that they do not observe [the Qur'an] is obvious; for they drink wine, they get inebriated with weed, they eat illicit things, they do not fast or pray, nor do they give what they can, and many other things which one knows better who tries to converse with them..$^{52}$

Furthermore, in his Epistolae he asserts that Muslims only 'appear' to have good works, ${ }^{53}$ and after praising the seven works of perfection in his Liber peregrinationis, he feels the need to add a disclaimer: "We have narrated the above less to praise Saracens than to shame certain Christians who refuse to do for the law of life what these damned do for the law of death." ${ }^{54}$ Here Riccoldo repeats an idea frequently repeated by other medievals: that while Muslim praxis often puts Christian praxis to shame, nevertheless it is void of efficacy because the underlying doctrine is false.

It is interesting to contrast Riccoldo's view of Islam with his view of Judaism; the former is informed by serious study and a decade of lived experience, while the latter is most decidedly not. Despite the fact that he claims to have witnessed a debate between Dominicans and Jews in the synagogue of Mosul, his section on Judaism does not seem to be informed by any personal experiences of Jews whatsoever, nor any knowledge of Hebrew. Unlike all the other sections of Ad nationes on Eastern Christians, Muslims, and Tartars, which

50 Contra legem, 115-16: "For [perjury], the feeding of ten poor boys is enough, or the giving away the same number of robes, or the freeing of one slave. However, he who cannot do these things will fast for three days (Qur'an 5:89)."

51 Contra legem, 142.

52 Contra legem, 141.

53 Epistolae, $150-151$.

54 LP, 216. 
are filled with detailed firsthand descriptions of their rituals, ${ }^{55}$ the section on Judaism alone contains almost nothing at all about Jewish ritual. Riccoldo only mentions circumcision and the observance of the Sabbath in passing, and he does so merely to say that there were times in history that Jews themselves did not practice these rituals (e.g., during the time of Maccabees). ${ }^{56}$

Unlike his unique account of Muslim praxis, Riccoldo's conclusions about Judaism are standard: Jews read the Old Law literally, they are blind for not accepting Christ as messiah, they crucified Christ knowingly, and their captivity is punishment for deicide. Riccoldo bases his argument largely on Augustine (some scholars claim that he is unique in preserving the 'Augustinian Witness' argument so late into the early fourteenth century), ${ }^{57}$ and copies much of his anti-Jewish polemic from Ramon Martís Capistrum Iudaeorum. Nevertheless, despite Riccoldo's reliance on Martí, he differs in tone, as Riccoldo is much more irenic. He refers to the Talmud only twice but does not condemn it, ${ }^{58}$ and also refers to Jewish 'captivity'59 rather sympathetically, possibly because he describes his own time in Baghdad as a kind of 'captivity.' 60

While Riccoldo frequently underscores his proficiency in Arabic and his personal experience of Muslims, he never claims to have studied Hebrew or to have had any extended contact with Jews. The disparity between his unremarkable, unoriginal account of Judaism and his exceptional and unique account of Islamic praxis may perhaps be explained by the disparity between his intellectual and personal experience-or lack thereof-of the two religious communities.

55 For example, in Ad nationes, section 103, Riccoldo discusses ritual diversity in Eastern Christianity by mentioning differences in Lenten fasting, communion recipients, the ingredients of communion bread including leaven, the kinds of chalices used, etc.

56 Ad nationes, sections 118-121.

57 Lydia Walker, "A Fourteenth Century Augustinian Approach to the Jews in Riccoldo da Monte Croce's Ad nationes orientales," Comparative Religion Publications (2011): Paper Three, 38 .

$5^{8}$ Walker, "A Fourteenth Century Augustinian Approach," 40.

59 Walker, "A Fourteenth Century Augustinian Approach," 39.

6o He begins his letters after the fall of Acre with this line (Epistolae, 137-38): "And so it came to pass that I was in Baghdad 'among captives on the banks of the Chebar' [Ez 1.1], the Tigris. A part of me delighted in the charm of the verdant place in which I found myself ... But the other part of me was urged to sadness over the slaughter and servitude of the Christian people and their degradation after the lamentable loss of Acre." 


\section{Conclusion}

Scholars have suggested that Christian arguments against Jews and Muslims have been increasingly connected, beginning in the twelfth century. ${ }^{61}$ Ryan Szpiech highlights how Islam was used in the construction of anti-Jewish arguments and suggests that, "like the imaginary Judaism of early anti-Jewish polemic, the idea of Islam took on, on limited occasions, a purely symbolic, hermeneutical role for Christian polemicists as witness to Christian truth." 62

While that may indeed be the case for some medieval authors, it is not so for Alan, Nicholas, or Riccoldo. Perhaps this is partly because the primary goal for none of them is to refute Judaism. Rather, they all have much broader aims. And this brings us back to the hierarchy of religions, utilized by all three of our authors. Within that hierarchy, Alan and Nicholas continuously see connections between the various religions and their rites. For Alan, Muslim wudu is clearly connected to other Muslim practices such as circumcision and polygyny, all of which he considers to be equally 'Judaizing.' Furthermore, he believes that Muslim wudu is likewise connected to heretical Christian forms of baptism. For Nicholas, who plays down the differences between Muslim wudu and Jewish mikveh, these ablutions (along with circumcision) are an opportunity to unite Christians, Jews, and Muslims, no matter how doctrinally problematic such a union might be. Unlike Alan and Nicholas, however, Riccoldo makes no explicit connections at all between the few Jewish rites he discusses (circumcision and Sabbath observance) and Muslim rites, to which he devotes a great deal of space. Of these three authors, only Riccoldo disconnects Muslim rites from the hierarchy of religions - if only for a while - by treating them separately and on their own terms. Of course, elsewhere he uses Muslim praxis to admonish Christians against their failures. Nevertheless, he begins with an accurate description of Muslim praxis as such.

Although Alan and Nicholas are furthest away from one another chronologically, it can be said that their views of Muslim and Jewish praxis are more similar to each other's than to Riccoldo's. Neither Alan nor Nicholas seems able to appreciate non-Christian rites on their own terms. Why? One reason might be that both Alan and Nicholas were unfamiliar with the lived reality of

61 Ryan Szpiech, "Hermeneutical Muslims? Islam as Witness in Christian Anti-Judaism," unpublished paper, and Jeremy Cohen, "The Muslim Connection; or, On the Changing Role of the Jew in High Medieval Theology," in From Witness to Witchcraft: Jews and Judaism in Medieval Christian Thought, ed. Jeremy Cohen (Weisbaden: Harrassowitz, 1997), 141-63.

62 Szpiech, "Hermeneutical Muslims," 6. 
the religions they describe. We have no evidence that Alan read Jewish texts on his own (after all, he copied nearly forty percent of his book on the Jews from Gilbert Crispin). And while he might have known Jews personally, given his northern French context, he does not draw on that experience in De fide. Furthermore, as far as we can tell, Alan does not use the most up-to-date information about Islam. Nicholas, similarly, had little if any personal experience of Jews or Muslims, and also had little knowledge of their texts at the time he wrote De pace. ${ }^{63}$

Riccoldo is different, at least in regard to Islam. He lived among Muslims for a decade and studied their literature in its original language. His Arabic was so advanced that not only does he brag about it repeatedly in his work, but he actually uses it to write marginal comments on an extant manuscript of an Arabic Qur'an. ${ }^{64}$ In stark contrast, Riccoldo's knowledge of Judaism is very limited; we can see this in his over-reliance on Ramon Martí, Petrus Alfonsi, and Augustine. Riccoldo's writings on Judaism and Jewish praxis do not demonstrate any knowledge of Hebrew, Jewish texts, or actual Jews. But in his discussion of Muslim praxis, Riccoldo's experience truly shines through. Only someone with extensive personal experience of a lived religion could have the ability to describe Muslim praxis with such detail. In Riccoldo we therefore see an interesting dichotomy: his views of Judaism are more like Alan's (because he copies from others and has no direct experience of Jews), but his views of Islam are unique; after all, his praise of the Muslim 'works of perfection' is so effusive that he feels the need to apologize for it twice! ${ }^{65}$

To conclude, in terms of their overall views of Muslim and Jewish rites, we see significant differences between these three medieval theologians. Lille is pessimistic (their rites are deficient sacraments), Cusa is optimistic (their rites have the potential to unify), and Riccoldo is stupefied, ambivalent, and uneven in his assessment, due to the asymmetry between his knowledge and experience of Judaism and Islam.

63 See Izbicki, "Nicholas of Cusa and the Jews," 119-130, and James Biechler, "A New Face toward Islam: Nicholas of Cusa and John of Segovia," in Nicholas of Cusa: In Search of God and Wisdom, ed. Gerald Christianson and Thomas Izbicki (Leiden: Brill, 1991), 185-202.

64 Riccoldo's Arabic knowledge has been confirmed recently by Thomas Burman, who suggests that the Latin marginal glosses in an Arabic Qur'an in Paris (Bibliothèque nationale de France, Ms fonds arabe 384) are the friar's. See Burman, "How an Italian Friar Read his Arabic Qur'an," Dante Studies 125 (2007): 89-105. For more on these glosses, see also François Déroche and José Martínez Gázquez, "Lire et traduire le Coran au Moyen Âge: les gloses latines du manuscrit arabe 384 de la BNF," Comptes rendus de l'Académie des inscriptions et belles-lettres 154 (2010): 1023-42.

65 LP, 211 and 216, respectively. 
Even though constructing a Christian theology of religions is primarily an internal task, that is, it requires the theologian to define other religions 'on Christian terms,' it is no less important for the theologian to attempt to understand the other, as much as possible, on that particular religion's own terms. This might seem anachronistic, yet all three medieval theologians discussed in this chapter did try to learn about Jewish and Muslim praxis as best they could. Alan remained rather ignorant about the concrete details of Muslim doctrine and practice, but he did try to get information on Judaism by going to a reliable source, namely, Gilbert Crispin. Although Nicholas's curiosity about Islam eventually led him to study the Quran in greater depth and consequently critique it, until this later point, his views of Islam (as expressed in De pace) were not much better informed than Alan's. Neither of them were able to appreciate or articulate the particularities of Jewish and Muslim practices, and instead set them aside too easily, either because they were thought to be too different from Christian practice (Alan), or similar enough (Nicholas). Therefore, Riccoldo's knowledge of Islam appears the deepest: he studied the Qur'an in Arabic with Muslim masters, attended Muslim schools, and observed Muslim praxis in situ. Partly because of this firsthand experience, Riccoldo takes Muslim rites seriously, and sometimes even 'on their own terms.' Of our three authors, he alone describes Muslim praxis in detail and with relative accuracy. And as a result, his assessment of Islam, though still quite negative, is better informed and much more nuanced. Hence, Riccoldo shows us that when constructing a Christian theology of religions, direct experience of the other really does matter. 


\title{
Perspectives on Islam in Italy and Byzantium in the Middle Ages and Renaissance
}

\author{
Marica Costigliolo
}

In this article I shall sketch some common features and differences between medieval and Renaissance approaches to Islam, which will be done by analyzing the various perceptions of Christian authors on Islam from the thirteenth to the fifteenth centuries. This is part of an extensive project on the formation of Western identity in the Middle Ages and the Renaissance, ${ }^{1}$ tracing the ways in which Latin and Byzantine thinkers defined their own civilization over and against Islam. In the line of scholars such as Nancy Bisaha, Thomas E. Burman, and Cary J. Nederman, who have illuminated the changing perceptions of Islam, ${ }^{2}$ I shall explore how both Western and Byzantine thinkers sought to deepen their approach to the foreign religion. Central to this story are the Renaissance humanists, whose views on the Turks acted as a bridge between medieval and modern attitudes regarding the West and Islam. ${ }^{3}$ Indeed, the exchange between Byzantium and the Latin West intensified as they formed strategic alliances against the Turkish enemy, ${ }^{4}$ and the consequent humanist

1 My extensive research project will also consider works of authors such as Bessarion, Plethon, Ciriaco d'Ancona, Guarino Veronese, Enea Silvio Piccolomini, Francesco Filelfo, Manuele Crysolora, and Nicetas Choniates.

2 Thomas E. Burman, Reading the Qur'an in Latin Christendom (Philadelphia: University of Pennsylvania Press, 2007); Cary J. Nederman, Worlds of Difference: European Discourses of Toleration, c. 100-c. 1500 (University Park, PA: Pennsylvania State University Press, 2000). Extremely relevant is the work Nancy Bisaha, Creating East and West: Renaissance Humanists and the Ottoman Turks (Philadelphia: University of Pennsylvania Press, 2004). See also Alain De Libera, La philosophie médiévale (Paris: Presses Universitaires de France, 1993).

3 Bisaha, Creating East and West, 9. See also William R. Jones, "The Image of the Barbarian in Medieval Europe," Comparative Studies in Society and History 13 (1971): 376-407; Michele Angelo Piemontese, "Il Corano latino di Ficino e i Corani arabi di Pico e Monchates," Rinascimento 36 (1996): 227-73; and Margaret Meserve, Empires of Islam in Renaissance Thought (Cambridge, MA: Harvard University Press, 2008).

4 James Hankins, "Renaissance Crusaders: Humanist Crusade Literature in the Age of Muhammad II," Dumbarton Oaks Papers 49, Symposium on Byzantium and the Italians, 13 th15th Centuries (1995): 111-207. 
responses to the Ottoman advance greatly influenced Western perceptions of the Turks and Islam, continuing to do so to this very day. However, to form their opinions, these humanists relied on earlier accounts of Islam, especially the Contra legem Sarracenorum, which was written by the thirteenth-century Dominican friar Riccoldo da Montecroce, and was one of the most widely circulated and influential works about Islam until the eighteenth century.

Due to its significance, I shall first briefly examine Riccoldo's Contra legem Sarracenorum $[C L S]$, and then trace its rich legacy as it was translated and used in the works of five representative authors from the fourteenth and fifteenth centuries. From these five, Fazio degli Uberti's Dittamondo shows that the CLS was so widely known that it was even echoed in fourteenth-century vernacular poetry. Riccoldo's work also informs the Byzantine responses to Islam in Demetrius Kydones' Pro subsidio Latinorum and De non reddenda Callipoli, and in the treatise On the Eternal Glory of the Autocrat by George of Trebizond, written to Mehmed II. Finally, Nicholas of Cusa's Cribratio Alkorani and Marsilio Ficino's De Christiana religione both adapt $C L S$ to argue that Islam presupposes Christian truth - a truth that Muslims nevertheless fail to acknowledge.

As we shall see, Riccoldo's legacy vividly demonstrates both the shift in rhetoric concerning Islam and Muslims, and the slowly changing perception of Islam from 'enemy' to 'other.' The circulation of texts on the interpretation of the Qur'an, especially Riccoldo's $C L S$, created a slow but growing knowledge about the affinities and the differences between Islam and Christianity, which consequently shaped the formation of a Christian and Western identity in opposition to the 'uncivilized' Turk. A pattern thus emerges: until the thirteenth century Islam was considered a terrifying enemy, however starting in the fourteenth century, apologetic and polemical works turned towards emphasizing the barbarism and ignorance of the Muslims more than the dangers that they posed. ${ }^{5}$

5 The transformation of the perception of another social or religious group is a slow process in cultural history, and it is possible to trace it through the analysis of metaphors, sentences, and the use of sources in the texts. By analyzing the repetitions, the differences or affinities with the previous tradition (in this case with $C L S$ ), or the insistence on one theme (the theme of 'ignorance') against another (the theme of 'enemy'), I demonstrate how during Humanism the perception of Islam begins to change. See Jan Assmann, Das kulturelle Gedächtnis: Schrift, Erinnerung und politische Identität in frühen Hochkulturen (München: C. H. Beck, 1992). 


\section{The Source on Islam from the Middle Ages to the Renaissance: Riccoldo da Montecroce}

To begin, let us first ask a fundamental question: What was the goal of Western humanists writing about Islam? Were they trying to increase general knowledge about Islam, or were they trying to erase all traces of Islamic influence on the West? An approach to answering this question can be provided by an analysis-for example, as undertaken by Thomas Burman and Norman Daniel $^{6}$ - of the work of Riccoldo da Montecroce, whose influential Contra legem Sarracenorum argues against the Qur'an, and in the process addresses wider issues of Christian-Muslim relations. This text is of major historical importance because of its vast influence, and remains strikingly relevant as it deals with relations between Christian and Muslims-a topic powerfully linked to political and social tensions today.

Riccoldo da Montecroce (1243-1320) was a Dominican friar at the priory of Santa Maria Novella in Florence. ${ }^{7}$ For many years he was a missionary in Mesopotamia (today's Iraq) and lived in Baghdad. We can reconstruct his biography through his works, some of which are kept at the National Library of Florence. In particular, his Liber peregrinationis (also known as the Itinerarium) describes his journeys in the Holy Land, Lebanon, Greece, Armenia, Turkey, Persia, and Mesopotamia, the land of the Chaldean Christians, where Riccoldo became acquainted with Jacobitism and Nestorianism. ${ }^{8}$

Nevertheless, his fundamental work is the Contra legem Sarracenorum, a work structured in the medieval form of quaestio..$^{9}$ Its tone is aggressive throughout, as Riccoldo seeks to demonstrate the irrationality and

6 Norman Daniel, Islam and the West: The Making of an Image (Edinburgh: Edinburgh University Press, 1960).

7 About Riccoldo da Montecroce, see Jean Marie Mérigoux, "L'ouvrage d'un frère prêcheur florentin en Orient à la fin du XIII siècle: Le Contra legem Sarracenorum de Riccoldo da Monte di Croce," in Memorie Domenicane 17 (Rome: Centro Riviste della Provincia Romana, 1986), 1-142; Mérigoux publishes the critical edition of Contra legem Sarracenorum, which will be cited as $C L S$, followed by Prologue or chapter and page number; translations are my own. Emilio Panella, "Ricerche su Riccoldo da Montecroce," Archivum Fratrum Praedicatorum 58 (1988): 5-85; Thomas E. Burman, "How an Italian Friar Read His Arabic Qur'an," Dante Studies 125 (2007): 93-109; Rita George-Tvrtkovic, A Christian Pilgrim in Medieval Iraq: Riccoldo da Montecroce's Encounter with Islam (Turnhout: Brepols, 2012).

8 Mérigoux, "L'ouvrage d'un frère prêcheur florentin," 22.

9 Giuseppe Rizzardi, "Introduzione," in I saraceni, Italian translation of the Contra legem saracenorum (Firenze: Nardini, 1992), especially $25-47$. 
insubstantiality of Islam. He describes Muhammad as a persecutor of the divine - that is, Christian—law, ${ }^{10}$ and Muslims, moreover, as persecutors of Christians.

In the first chapter, Riccoldo writes that Muhammad's principal intention is to convince readers that Christ is neither a god nor the Son of God, but only a wise man. ${ }^{11}$ Accordingly, Riccoldo outlines the affinities between Islam and heresies such as Arianism and Manichaeism. Furthermore, he underlines the lecherous reputation of Muhammad, as the Prophet affirms, according to Riccoldo, that beatitude consists in carnal pleasures and in food, in marvelous clothes, and in living in gardens rich in water. To support this, Riccoldo notes that in the Qur'an Muhammad aims to eliminate everything that is difficult to believe or to do, and instead permits believers to indulge the sensual pleasures. In chapter two of his work, Riccoldo writes that because Muslims cannot grasp the mystery of the Trinity, it is easier to prove to them that their own law is false than to prove the truth of the Christian religion. ${ }^{12}$

Later in the second chapter, Riccoldo continues to relate that the Saracens deny the miracles and words of the Apostles, since they contradict the Qur'an. He insists that the Qur'an is not a divine law but is in fact perfidious, and that the Saracens must therefore accept the authority of the Gospel. To demonstrate these arguments he turns to his analysis of the Qur'an, pointing out several times the theme of violence. Thus, he concludes that the Qur'an does not fit with the divine law, since God's law does not permit murder, robbery, and concupiscence, while the Qur'an, on the contrary, does. Throughout the work, Riccoldo describes Muhammad as being wicked, a thief, adulterous, incestuous, and as a man who committed homicide. ${ }^{13}$ Then, in chapter ten, Riccoldo repeats that the Qur'an promotes violence. By insisting on the violence inherent in Islam and Muhammad's cruel nature, Riccoldo aims to demonstrate the dangerous threat that Islam poses to Christianity.

Another tactic Riccoldo employs for this purpose is to point out contradictions in the Qur'an. ${ }^{14}$ Furthermore, he argues that the Saracen law contains not only many contradictions, but also many lies and fabrications. He also points out the lack of logic or order in the Qur'an, and therefore states in chapter eleven: "I do not remember finding in all of that book [the Quran] an adequate

\footnotetext{
$10 \quad C L S$, Prologus, 62.

$11 C L S$, ch. $1,64$.

$12 C L S$, ch. 2, 69.

$13 \quad C L S$, ch. 8, 91-93.

$14 C L S$, ch. $6,83$.
} 
argument. This law cannot derive from God, since it does not follow any order."15 $^{15}$

Defensive arguments are also found throughout the treatise, as Riccoldo felt the need to defend Christianity against a powerful enemy. He does this in three ways. Following the Dominican rhetorical tradition, he first presents some sentences from the Quran in order to prove their falsity. In contrast to these, he then exalts the coherence of the Christian texts and the rationality of Christian doctrine. Finally, he turns the Islamic denial of miracles against the 'Muslim law' itself, since — unlike Christian faith—Islam cannot be verified by miracles. ${ }^{16}$

In sum, in the work of Riccoldo we can note the following elements: there is a patent fear of Islam as the enemy of Christianity and its persecutor, and accordingly, there is a rhetorical use of many defensive arguments, as well as a stress on the irrationality of the Qur'an. As we shall see, Riccoldo's later readers used and modified these elements from the $c L S$ in their own writings.

\section{The Stereotypes about Islam in a Vernacular Work: Fazio degli Uberti}

One of the many genres influenced by Riccoldo's Contra Legem Sarracenorum is the vernacular literature from fourteenth-century Italy. ${ }^{17}$ For example, the poet Fazio degli Uberti (1301-1367) makes extensive use of the $C L S$ in his Dittamondo (c. 1345), ${ }^{18}$ an encyclopedic poem in six books with a meter of chained

$15 \quad C L S$, ch. 11, 113.

16 CLS, ch. 7, 90.

17 For example, Cod. 205, University of Bologna, cited in Fazio degli Uberti, Il Dittamondo e le rime, ed. Giuseppe Corsi (Rome: Laterza, 1952), 333.

18 About the work of Fazio degli Uberti, see Corsi's introduction to his edition of Dittamondo, and Charles Edward Whitmore, The Lyrics of Fazio degli Uberti in their relation to Dante (Boston: Ginn \& Co, 1917). For a biography of Fazio, see Filippo Villani, De civitatis Florentiae et eiusdem famosis civibus, ed. Giovanni Calò (Rocca San Casciano: L. Cappelli, 1904). For additional information on Fazio, see Eleanor F. Jordain, "Holyday's 'Survey of the World' and the Dittamondo" The Modern Language Review 2/1 (1906): 44-55. Also intriguing is the relationship between Fazio and Dante, in order to trace the possible influence of Riccoldo in the work of Dante; see, for example, Leonardo Olschki, "Mohammedan Eschatology and Dante's Other World," Comparative Literature 3/1 (1951): 1-17; John Tolan, "Mendicants and Muslims in Dante's Florence," Dante Studies 125 (2007): 227-48; and Karla Mallette, "Muhammad in Hell Author(s)," Dante Studies 125 (2007): 207-24. See also 
triplets. ${ }^{19}$ The theme of the poem is a journey through Europe, North Africa, and Palestine. Many legends and much of its geographical and historical information are drawn from the works of Solino, Pliny the Elder, Martin Polonio, and Riccoldo. Of the latter, Fazio writes, "Here I came and I heard about Riccoldo / Po di qua venni e di Ricoldo m'è deto,"20 and Dittamondo does indeed contain many details about the Islamic tradition from $C L S$. Furthermore, Riccoldo had travelled along the same route that Fazio intended to take, namely, the route in the eastern lands, although Fazio died before completing his poem and travels.

In Book Five, chapters ten-twelve and fourteen are dedicated to explaining the Islamic religion and the figure of Muhammad. Among the claims about the Prophet that Fazio includes ${ }^{21}$ is Riccoldo's assertion that Muhammad was lascivious and inclined to drink. ${ }^{22}$ Fazio repeats this assertion in chapter Twelve, ${ }^{23}$ where he describes Muhammad as attracted to the vices of gluttony and lust. Another theme likely drawn from the $C L S$ is the absence of miracles in the Islamic tradition. ${ }^{24}$ According to Fazio, Muhammad raised no one from the dead, nor did he heal the blind or disabled, but instead, he often received his support through weapons. Fazio thus recalls the argument of the sword that is found in the $c L s$ : Muhammad proclaims that he was not sent to perform miracles but to fight with weapons, to which the priests of the Quran then wave the sword. ${ }^{25}$ The themes of the sword and violence are also repeated to support the argument of the inconsistency of Qur'anic law: in the Qur'an, Fazio recounts, we read many indecent things, but it also commands believers to obey Muhammad or to die. ${ }^{26}$

Although he attributes all information about Islam to Riccoldo, it is unclear whether Dittamondo in reality relies solely on this text as a source about Islam. ${ }^{27}$ For example, Fazio quotes the Qur'an to illustrate a legend that is

José Martínez Gázquez and Andrew Gray, “Translations of the Qur’an and Other Islamic Texts before Dante," Dante Studies 125 (2007): 79-92.

19 Pierangela Izzi, "Il vocabolario dantesco nel Dittamondo di Fazio degli Uberti," www.italianisti.it.

20 Henceforth, I shall cite Corsi's edition of Dittamondo by page, Book, and chapter, as here:

Dittamondo, 364, Bk. 5, c. 9 .

21 Dittamondo, 365, Bk. 5, c. 10.

22 Dittamondo, 368 , Bk. 5, c. 11.

23 Dittamondo, 373, Bk. 5, c. 13.

24 Dittamondo, 374, Bk. 5, c. 13.

25 Dittamondo, 371, Bk. 5, c. 12.

26 Dittamondo, 371, Bk. 5, c. 12.

27 Corsi, Dittamondo, appendix, vol. ii, 330-33. 
found in the $C L S$, while Riccoldo correctly locates the legend's source not in the Qur'an, but in the Doctrina Machumeti. This misattribution reflects Fazio's broader confusion about his sources, and we are aware now that he also drew from the Legenda Aurea of Jacopo da Voragine.

Nevertheless, in the work of Fazio we can observe the use of $c L S$ as the main source of information about Islam in a vernacular work, and there is a clear repetition of Riccoldo's stereotypes about the Islamic tradition and the figure of Muhammad. And yet, Fazio takes a noticeably less aggressive tone towards Muhammad and the Islamic tradition than Riccoldo does.

\section{Different Rhetoric on Islam: Demetrius Kydones and George of Trebizond}

Alongside its usage by fourteenth-century Italian writers, as discussed above, the $C L S$ was also utilized by Byzantine scholars. By analyzing works of two such scholars, Demetrius Kydones and George of Trebizond, we can see how they use Riccoldo's work, and repeat his stereotypes of Islam, as well. Yet their rhetoric also displays a shift from perceiving Islam as an 'enemy' to viewing the Turks as merely 'uncivilized. 28

\section{A Demetrius Kydones}

Demetrius Kydones (1324-1398) was a Byzantine humanist at the Court of John Kantakouzenos, a mesazon or minister for government affairs. He was the teacher of George Gemisto Plethon, and had also travelled to Italy, where he intensively studied Latin culture. ${ }^{29}$ His work is important for two main reasons:

28 The works of Kydones and Trebizond show also that "one last variable that encouraged classical treatment of the Turks was the influence of contemporary Byzantine attitudes. The result was not only an increase in classically inspired rhetoric on the Turks but also the development of a more unified discourse of European civility versus Asian barbarism," as Bisaha rightly states (Creating East and West, 44).

On Kydones, see Giovanni Mercati, Notizie di Procoro e Demetrio Cidone, Manuele Caleca e Teodoro Meliteniota (Vatican City: Biblioteca Apostolica Vaticana, 1931). Cf. Frances Kianka, Demetrius Cydones (c. 1324-c.1397): Intellectual and Diplomatic Relations between Byzantium and the West in the Fourteenth Century (Ph.D. diss.: Fordham University, 1981); and Raymond-Joseph Loenertz, ed., Démétrius Cydonès: Correspondance, 2 vols. (Vatican City: Biblioteca apostolica vaticana, 1956, 1960). Cf. George T. Dennis, "Demetrios Cydones and Venice," in Bisanzio, Venezia e il mondo franco-greco (XIII-XVsecolo): Atti del Convegno Internazionale Organizzato nel Centenario della nascita di Raimond-Joseph Loenertz O.P., Venezia, 1-2 dicembre 2000 (Venice: Istituto ellenico di Studi Bizantini e Postbizantini di 
he translated many works from Latin into Greek, among them the Summa contra gentiles of Thomas Aquinas, and he was dedicated to fighting the Ottomans. Furthermore, his works provide valuable insight into the Byzantine scholar's attitude towards both Ottomans and Latins.

He is also responsible for translating Riccoldo's Contra legem Sarracenorum from Latin into Greek, ${ }^{30}$ and sent the work to Emperor Manuel II in 1358. Nor is this the end of the story - in the late fifteenth century, Bartolomeo Picerno di Montearduo retranslated $c L s$ back into Latin from Kydones's Greek, ${ }^{31}$ and dedicated it to Ferdinand II, king of Aragon and Sicily. In the prologue, Bartolomeo asserts that Kydones' Greek translation admirably enriches Riccoldo's original text. Hence, rather than sending Riccoldo's Latin text directly, Bartolomeo was motivated to retranslate the $c L S$ into more elegant Latin, as a gift to the king who was fighting the Muslims in Spain. These different versions of the $C L S$ show how Riccoldo's treatise against Islam circulated from the Byzantine territories to Spain, and highlight the relation between Byzantine scholars and the Latin heritage. Moreover, they also exemplify how a common image of Muslims was building between the Western and Eastern Empires.

Kydones's approach towards the Turks can be seen in his works about relations with the Ottomans, namely, the Pro subsidio Latinorum (1366) and the De non reddenda Callipoli (1369). ${ }^{32}$ Both works concern the site of Gallipoli (Turkey), a strategic point in the Hellespont, and both are important sources about the political strategies of the Byzantines towards the Ottomans and Latins. Following the surrender of Gallipoli to the Turks, Kydones calls for

Venezia, 2002), 495-502. See also Dimiter G. Angelov, ed., Church and Society in Late Byzantium (Kalamazoo, MI: Medieval Institute Publications, 2009); Judith R. Ryder, The Career and Writings of Demetrius Kydones: A Study of Fourteenth-Byzantine Politics, Religion and Society (Leiden: Brill, 2010); Vasileios Syros, "Between Chimera and Charybdis: Byzantine and Post-Byzantine Views on the Political Organization of the Italian CityStates," Journal of Early Modern History 14 (2010): 1-54. See also Frances Kianka, "Demetrios Kydones and Italy," Dumbarton Oaks Papers 49 (1995): 99-110; Frances Kianka, "Byzantine-Papal Diplomacy: The Role of Demetrius Cydones," The International History Review 7/2 (May, 1985): 175-213; and Ihor Ševcenko, "The Decline of Byzantium Seen through the Eyes of its Intellectuals," Dumbarton Oaks Papers 15 (1961): 167-86.

Ryder, The Career and Writings of Demetrius Kydones, 156 . The translation, dated 1350, is found in PG 154. See Mérigoux, "L'ouvrage d'un frère prêcheur florentin," 58 , as well as works by Kianka, Ryder, and Mercati.

31 The Latin version of $C L S$, translated by Picerno, is in PG 154.

32 Demetrius Kydones, Oratio pro subsidio Latinorum, PG 154, cols. 961-1008; and De non reddenda Callipoli, PG 154, cols. 1012D-1013B. 
Latin assistance, considering the Latins as allies of Byzantium in the fight against the Ottomans, the enemies of freedom. ${ }^{33}$ The De non reddenda points to the fall of Gallipoli in 1354 as immediately "provoking great panic, while his work on the Contra legem Sarracenorum shows him already concerned with a theological confrontation with Islam." ${ }^{34}$ Also, in the Oratio pro subsidio Latinorum, Kydones affirms that western Europe and the papacy were not Byzantium's enemies, but rather, its most natural political and military allies against the aggression of the Turks. ${ }^{35}$

How does Kydones describe the Ottomans in these works? He uses term 'barbaroi' to describe the Turks, which he uses to refer to other social groups as well. As in the $c L s$, the Turks are represented as fundamentally uncivilized and cruel, with "all characteristics directly in contrast with the Christians of the oikumene," 36 where 'Christianity' means the unity of the Latin and Greek Churches. Here we see at play the process of building Western identity as a phenomenon in contrast with the Islamic tradition. ${ }^{37}$

Another description of the Turks emphasizes the "cupiditas Barbarorum," 38 which is a way of underlining the evil nature of the Ottomans; this also seems to recall the argument of $C L S$ about the depraved attitude of Muslims. Nevertheless, in $c L S$ the mistakes of Muslims are connected to the errors of Muhammad as a false prophet, while in Kydones's works, the negative attributes describe the entire community of Muslims, in contrast with the virtuous Christians. Kydones also recalls the violent character of the Islamic people, and affirms that they conquered the Greek territories though the use of enslavement and violence. ${ }^{39}$ Again, this theme of violence echoes Riccoldo's $C L S$.

33 See Ryder, Career and Writings of Kydones, 79.

34 Ryder, Career and Writings of Kydones, 156.

35 Kianka, "Kydones and Italy," 103.

36 Ryder, Career and Writings of Kydones, 59. About the relationship between Byzantium and Islam, see Adel-Théodor Khoury, Les théologiens byzantins et l'Islam: textes et auteurs (VIII-XIII s.) (Paris-Louvain: Béatrice-Nauwelaerts, 1969).

37 See Kianka, "Demetrios Kydones and Italy," 102: "Kydones attempted solutions [through] anti-Turkish, pro-Latin policy and an intellectual appreciation for and defence of the philosophy and theology of the Latin West, seen primarily in his attraction to the work of Thomas Aquinas."

38 Demetrius Kydones, De non reddenda Callipoli, PG 154, 1027.

39 See Kianka, "Demetrios Kydones and Italy," 103: "Faced with the continuing conquests and settlements of the Ottoman Turks in Byzantine territory, especially in Thrace, [Kydones] pursued the forging of alliances with the Catholic powers of the West - a new crusade, directed not at the recovery of the Holy Land but at rescuing what remained of Byzantine lands from the aggression of their Muslim enemy." 
In summary, we can identify three distinguishing features in Kydones's writings: his scorn towards the Ottomans, called 'barbaroi;' an attempt to unify the Latin and Greek Churches against the Ottomans; and the influence of the CLS on his approach to Islam.

\section{B George of Trebizond}

In his response to the Turks, George of Trebizond uses a very different rhetoric. Rather than employing Kydones's approach of scorning the Turks to build an alliance with the Latin West, Trebizond aims instead to convert the sultan Mehmed II, and hence his tone is more subdued and even laudatory.

George of Trebizond (1395-1472/73) was born in Crete, then converted to Roman Catholicism and began a new life in Italy, all the while remaining devoted to the Greek cause. ${ }^{40}$ For most of his career he was attached to the papal court as a secretary and Greek translator, but he also lectured and taught in Florence, Rome, and Venice on topics such as rhetoric, poetry, and the Greek language.

Here we shall focus on Trebizond's treatise On the Eternal Glory of the Autocrat and His World Empire, written to the Emir, Mehmed II, when he stormed Constantinople, as an attempt to convert him to Christianity. We also find this attempt in other works of Trebizond, addressed to Mehmed as well. ${ }^{41}$

The translation and comments on Trebizond works are in John Monfasani, ed., Collectanea Trapezuntiana: Texts, Documents and Bibliographies of George Trebizond (Binghamton, N.Y.: Medieval \& Renaissance Texts \& Studies in conjunction with the Renaissance Society of America, 1984). George Trebizond, "Preface of His Translation of Plato's Laws," trans. John Monfasani, in Cambridge Translations of Renaissance Philosophical Texts, vol. 2: Political Philosophy, ed. Jill Kraye (Cambridge: Cambridge University Press, 1997), 128-34. See Thomas Berns, "Construire un idéal vénitien de la constitution mixte à la Renaissance: L'enseignement de Platon par Trébizonde," in Le Gouvernement mixte (SaintEtienne: Université de Saint-Etienne, 2005), 25-38; Franco Gaeta, "Giorgio da Trebisonda, le Leggi di Platone e la costituzione di Venezia," Bullettino dell'Istituto storico italiano per il Medio Evo e Archivio Muratoriano 82 (1970): 479-501; John Monfasani, George of Trebizond: a Biography and a Study of His Rhetoric and Logic (Leiden: E. J. Brill, 1976), 171-74; Giorgio Ravegnani, "Nota sul pensiero politico di Giorgio da Trebisonda," Aevum 49 (1975): 310329; and Carl Joachim Classen, "The Rhetorical Works of George of Trebizond and Their Debt to Cicero," Journal of the Warburg and Courtauld Institutes 56 (1993): $75^{-84}$. See Bisaha, Creating East and West, 116: "George of Trebizond, by focusing on Greece's position in antiquity as defender of all Europe, and therefore as a crucial part of Europe,... firmly brings Byzantium within the Western cultural identity." See Monfasani, George of Trebizond, 131-136. 
As John Monfasani notes about one of these treatises, On the Truth of Faith of Christians to the Emir, written in 1453:

Nor was he alone in attempting to convert Muhammad II. We have the famous letter of Pope Pius II to the Conqueror. Scholars have never fathomed what George meant by this letter. He was not motivated by an extraordinary irenic spirit, as some have suggested, nor by eccentric political ideas, as others have supposed. ${ }^{42}$

According to Monfasani, the answer to what motivated Trebizond lies in his treatise On the Eternal Glory of the Autocrat and in another letter to Mehmed II, On Divine Manuel, Shortly to be King of the Whole World. ${ }^{43}$ These writings are inspired by the apocalyptic text of Pseudo-Methodius, who predicted that the sons of Ishmael would conquer the Latin Empire. ${ }^{44}$ Thus,

By converting Mehmed II, Trebizond hoped to avert the dreadful reign of the Ishmaelites: he would remake the Moslem conqueror of Constantinople into the universal Christian Emperor. Trebizond considers Greece and Latin West as a unity. ${ }^{45}$

How, then, does George of Trebizond try to convert Mehmed II? Which rhetorical strategies does he use? In On the Eternal Glory of the Autocrat, he calls Mehmed II 'King of kings' and 'Mightiness,' 46 and his words in general are extremely positive towards Mehmed II: "Now I do not think it escapes you, $\mathrm{O}$ wondrous autocrat, that God has selected you and yours to rule the whole world." 47

42 Monfasani, George of Trebizond, 131.

43 George of Trebizond, "On the Eternal Glory of the Autocrat," and "On the Divinity of Manuel," in Collectanea Trapezuntiana, 492-527, 564-574.

44 Monfasani, George of Trebizond, 132: "According to the script of Pseudo-Methodius, the all conquering Ishmaelites would usher in a reign of terror which would only end when the last true Christian emperor arose to disperse them and bring about the reign of peace which must precede the coming of Gog, Magog, and the Antichrist."

45 Ibid.

46 George of Trebizond, "On the Eternal Glory of the Autocrat," in Collectanea Trapezuntiana. See Bisaha, Creating East and West, 136: "By combining aspects of medieval conversion treatises with humanist rhetoric, they hoped to persuade the Turks to accept the enlightened path of Christianity."

47 George of Trebizond, "On the Eternal Glory of the Autocrat," in Collectanea Trapezuntiana, 524 . 
At the beginning of On the Eternal Glory of the Autocrat, Trebizond proposes to use the Aristotelian rule "by which in the comparison of conflicting propositions, men would find the truth and cast falsity aside,"48 since he had heard that "every day you [Mehmed] philosophize as much as possible."49 Although this text exalts Mehmed, we also note some topics drawn from the medieval tradition. Was Trebizond then familiar with the work of Riccoldo? The answer to this question is 'probably,' since he quotes Demetrius Kydones, the translator of the $C L S$, in a letter from $145^{2}$ (Exhortation to Pope Nicholas V Ad defendenda pro Europa Hellesponti claustra), ${ }^{50}$ and because in On the Eternal Glory of the Autocrat we find many topics about Islam that are also present in $C L S$, such as: how it is difficult for Muslims to comprehend the Trinity (from chapter six to chapter sixteen), as well as the crucifixion and death of Christ (fifteen-sixteen) and his resurrection (chapter seventeen).51 But unlike Riccoldo, George of Trebizond believes that for Mehmed, and indeed for all Muslim people, it is necessary to convert to Christianity, however difficult it may be. Furthermore, for Trebizond, the only real hope to save the Christian empire is by converting Mehmed II.

In this work, Trebizond perceives Westerners and Byzantines as a unity against the Turks. ${ }^{52}$ This perception changed, however, after being warned of the capture of Constantinople, ${ }^{53}$ as becomes clear in another work, the abovementioned Exhortation to Pope Nicholas V. Here, the author requested the

48 George of Trebizond "On the Eternal Glory of the Autocrat," in Collectanea Trapezuntiana, 496.

49 Ibid.

5o George of Trebizond, "Exhortation to Pope Nicholas V ad defendenda pro Europa Hellesponti claustra," in Collectanea Trapenzuntiana, 434-444.

51 George of Trebizond, "On the Eternal Glory of the Autocrat," in Collectanea Trapenzuntiana. Although these themes are common in the medieval tradition on Islam, $C L S$ was the most popular treatise on the Qur'an. Furthermore, in Trebizond's elite circle of humanists, Riccoldo's treatise was read and used. About the relations between Byzantine and Italian scholars, see Kenneth M. Setton, "The Byzantine Background to the Italian Renaissance," Proceedings of the American Philosophical Society 100/1 (1956): 1-76. See also Mérigoux, "L'ouvrage d'un frère precheur florentin," 53: "George of Trebizond, humanist and theologian was affected by the influence of the work of Riccoldo."

$5^{2}$ See Bisaha, Creating East and West, 132: "Despite the hostility Europeans once felt toward Byzantines, and which some individuals continued to express, the year 1453 marked the beginning of a change in Western perceptions of the Greeks. Greeks had been settling in Italy before this date, and thousands more came to settle afterward."

53 About this point, see Carlo Maria Mazzucchi and Agostino Pertusi, Bisanzio e i Turchi nella cultura del Rinascimento e del Barocco (Milan: Vita e Pensiero, 2004); Roberto Weiss, 
Pope's help in order to protect Constantinople from the Turks. Undoubtedly, it was after the fall of Constantinople that Trebizond's approach to Islam changed. Whereas he previously considered the Pope as the only one who could save the Empire, in his letter of 1466 to Mehmed, Trebizond requests the help of the Autocrat himself. I suggest that this change was caused by multiple factors. First, it was due to geopolitical strategy: after the fall of Constantinople, Christians inevitably acknowledged Mehmed to be both a great conqueror and a great political figure, as the famous letter of Pius II shows. ${ }^{54}$ Second, there were traditional theological and eschatological beliefs involved (like the prediction of Pseudo-Methodius), as Monfasani stresses. ${ }^{55}$ Third, there began a slow evolution in the perception of Muslims, who were no longer viewed so much as 'enemies,' but rather as Christians who did not know that they are Christians.

Although Trebizond uses many topics from medieval tradition-for example, the insistence on the incapacity of Muslims to grasp the truth of Trinityhe nevertheless attempts to convert Mehmed by using an elaborate rhetoric of praise, rather than a fierce diatribe like Riccoldo's. Thus, in the works of Trebizond, the perception of Islam seems to change yet again: Mehmed is no longer considered an 'enemy', but instead becomes a possible ally.

\section{Nicholas of Cusa and Marsilio Ficino: 'Presupposition' and the Changing Face of Islam}

The following section will highlight the use of $C L S$ in Nicholas of Cusa's Cribratio Alkorani and Marsilio Ficino's De Christiana religione. Specifically, I shall discuss Cusanus and Ficino's rhetorical strategy of praesuppositio, namely, their claim that whatever is true in the Qur'an reflects its borrowings from the Christian Scripture, which it 'presupposes.' We shall also see how this strategy fits within the larger scheme of perceptions shifting from Islam as 'enemy' to 'other.'

La scoperta dell'antichità classica nel Rinascimento, Italian translation (Padua: Antenore, 1989).

54 Enea Silvio Piccolomini, "Letter to Mehmed II"; see Luca d'Ascia, Il Corano e la tiara (Bologna: Pendragon, 2001).

Monfasani, George of Trebizond, in particular 131-135. 


\section{A Nicholas of Cusa}

Nicholas of Cusa (1401-1464) $)^{56}$ knew Riccoldo's $C L S$ well. Cusanus himself informs us: "In Rome I saw the book of Brother Riccoldo, of the Order of Preachers, who studied Arabic in Baghdad; this [book] was more gratifying than the others. ${ }^{\prime 57}$ Nicholas's manuscript of $C L S$, with marginal notes in his own hand, survives in his library at St. Nicholas Hospital in Bernkastel-Kues, ${ }^{58}$ and his Cribratio Alkorani makes extensive use of it. However, according to Jean Marie Mérigoux, Cusanus distorts the original intention of $C L S$, because instead of considering it a missionary theological work, he sees it as a source of information on Islamic culture and religion. ${ }^{59}$

Nicholas of Cusa wrote the Cribratio Alkorani in 1461, three years before his death. This work is dedicated to Pope Pius II, who is urged to consider the 'Mohammedan sect' as originating from the Nestorian heresy and, consequently, erroneous but able to be refuted. Following $C L S$, Nicholas writes about Muslim violence against Christians, the overall violent nature of the Qur'anic law, and the 'continuous persecutions' put into effect by the Muslims against Christian populations. ${ }^{60}$ Cusanus insists over and over again on

56 On Nicholas of Cusa and Islam, see the essays in Part I this volume. See also James E. Biechler, "Interreligious Dialogue," in Introducing Nicholas of Cusa: A Guide to a Renaissance Man, ed. Chistopher M. Bellitto, Thomas M. Izbicki and Gerald Christianson (Mahwah: Paulist Press, 2004), 270-96; G. Christianson and T. M. Izbicki, eds., Nicholas of Cusa: In Search of God and Wisdom (Leiden: Brill, 1991); Walter A. Euler and Tom Kerger, eds., Cusanus und der Islam (Tier: Paulinus, 2010); Pim Valkenberg, "Sifting the Qur’an: Two Forms of Interreligious Hermeneutics in Nicholas of Cusa," in Interreligious Hermeneutics in Pluralistic Europe, ed. D. Cheetham, U. Winkler, O. Leirvik and J. Gruber (Amsterdam: Rodopi, 2011), 27-48; Rita George-Tvrtkovic, "After the Fall: Riccoldo da Montecroce and Nicholas of Cusa on Religious Diversity," Theological Studies 73 (2012): 641-62; Marica Costigliolo, Islam e cristianesimo: mondi di differenze nel Medioevo. Il dialogo con l'Islam nell'opera di Nicola da Cusa (Genoa: Genova University Press, 2012).

The critical edition of Cribratio Alkorani is in Ludwig Hagemann, ed., Nicolai de Cusa Opera omnia, vol. 8 (Hamburg: Felix Meiner, 1986). I shall cite this edition by Prologue or Book, chapter, paragraph number (n.), and lines, as here: Prol., n. 4, lines. $3-5$ : "Vidi... Romae libellum fratris Ricoldi ordinis praedicatorum qui arabicis literis in baldach operam dedit et plus caeteris placuit." English translation by Jasper Hopkins in Complete Philosophical and Theological Treatises of Nicholas of Cusa, vol. II (Minneapolis: Banning, 2001), 963-1105, here, 966.

$5^{8}$ James E. Biechler, "Three Manuscripts on Islam from the Library of Nicholas of Cusa," Manuscripta 27 (1983): 91-100. See also Marica Costigliolo, "Qur’anic Sources of Nicholas of Cusa," Mediaevitisk 24 (2011): 219-238.

59 Mérigoux, "L'ouvrage d'un frère precheur florentin," 48.

6o Cribratio Alkorani, III, iii, n. 168. 
Muhammad's dominating actions. ${ }^{61} \mathrm{He}$ also acknowledges that Christians might convert to Islam but will nonetheless remain Christian in their hearts; he therefore argues that persecution on religious grounds is senseless for both religions. ${ }^{62}$ In Cusanus's opinion, Muhammad's sole purpose was to pursue power through the sword, to extend his property on the pretext of religion and God. ${ }^{63}$ Muhammad's work on the Quran would be completed later, thanks to a group of counselors, among whose number were some heretical Christians and 'perverse' Jews. ${ }^{64}$

Nicholas describes the Cribratio's project as follows:

Nonetheless, we intend to critically examine, presupposing the Gospel of Christ, Muhammad's book, and prove that also that book includes some things, which would notably confirm the Gospel, should it need to be confirmed, and wherever it disagrees with the Gospel, it was caused by ignorance, and consequently, by perversity in Muhammad's intentions.... For he did not pursue the glory of God and the salvation of man, but rather his own glory. 65

Nicholas's comment - that 'the Qur'an confirms the truth of the Gospel'severely limits his textual hermeneutics because he declares that he already knows the outcome of his analysis, namely, the affirmation of the Gospel's truth through an analysis of the Qur'an. To support this thought, Nicholas wants to thoroughly and critically examine (cribrare) the Qur'an. To do so, he makes use of 'pia interpretatio' (pious or faithful interpretation), ${ }^{66}$ a method he had already used in his dialogue De pace fidei (1453). He thus begins his argument from a conceptual principle that he had developed in his earlier dialogical work: there is only one truth, the truth of the Gospel, and no comparisons can be made without this presupposition. However, in the Cribratio, praesuppositio is no longer used to prove the uniqueness of truth appearing in a variety

61 In particular, Cribratio Alkorani, III, viii n. 184.

62 Cribratio Alkorani, III, vi, n. 180, lines 10-15.

63 Cribratio Alkorani, III, viii, n. 184, lines 1-5.

64 Cribratio Alkorani, I, i, n. 23, lines 9-11.

65 Cribratio Alkorani, Prol., n. 10, lines 1-7, my translation.

66 See J. Biechler, "Interreligious Dialogue," 289: "The Sifting utilizes a hermeneutic principle which like the foregoing elements, has an ameliorative effect on the Christian-Muslim confrontation. Cusanus uses what he terms an interpretatio pia, a kind of benign understanding by means of which certain Qur'anic passages are understood in a sense not contradictory to Christian belief." See also P. Valkenberg, "Sifting the Qur'an," 36-46; and Cribratio Alkorani, II, xii, nn. 119-120. 
of rites, ${ }^{67}$ but instead, is meant to demonstrate the wicked intention of the Qur'an's author Muhammad, who, Nicholas claims, perversely subverted the truth of the Gospel.

The Cribratio Alkorani is grounded on the premise that if the Qur'an is correctly understood, it shall prove the truth of the Gospel, as Nicholas affirms in the work's prologue. The work is filled with polemical and apologetic intentions, and consistently uses the rhetorical strategy of praesuppositio. Cusanus does not deal with the specific traditions and rites of Islam, as he had done previously in De pace fidei. Here his gaze is not introspective and self-critical, and he does not attempt to investigate whether historical reasons or common affinities exist. Rather, Nicholas does not change his general theoretical approach and resorts to the same concepts expounded in his previous theological works, since here too he analyzes the differences between the two religions based on the presupposition that the truth is in the Gospel. Hence, he concludes that if anything beautiful or truthful can be found in the Qur'an, it necessarily originates from the Gospel. ${ }^{68}$

In the Cribratio, Cusanus presents two different kinds of analyses of the Quranic text. First, Nicholas examines the Qur'an without criticizing its contents, since he wants to confront his opponent on equal terms and prove that the Qur'an actually bears witness to Christian truths. But at the same time, Nicholas also intends to prove that the Qur'anic text cannot be the fruit of a divine revelation. Thus, the Cribratio shows a strong textual consistency with both the tradition of the Bible and Nicholas's own thought. This consistency emerges in particular in his comparison between the holy books, especially in the chapter entitled "The Qur'an is not trustworthy in the points in which it contradicts the Holy Scriptures." ${ }^{\prime 9}$ Nicholas maintains that in a comparison between the two holy books, the term 'variation' means not only the replacement of words, but also the different meaning of the Qur'an's words compared to the evangelical word. In that case, he adds, the Qur'an cannot be justified; therefore, we must admit that it was not God who transmitted the Quranic word to Muhammad. ${ }^{70}$

Hence, the use of praesuppositio can be seen as part of the slow transformation of the perception of Turks from 'enemy' into 'other.' Indeed, Cusanus considers Muslims 'different' from Christians because of their ignorance, and he

67 See Pim Valkenberg, "Una Religio in Rituum Varietate: Religious Pluralism, the Qur’an, and Nicholas of Cusa," in this volume.

68 Cribratio Alkorani, I, vi, n. 41, lines 1-5.

69 Cribratio Alkorani, III, vi, n. 179, lines 10-15.

70 Cribratio Alkorani, III, vii, n. 183, lines 12-16. 
underlines the obliviousness of Muslims, who must be converted to Christianity. To summarize, Cusanus's Cribratio Alkorani exhibits two key features: a reliance on $C L S$ for many themes, including the violence of the Qur'anic law, and the use of praesuppositio to guide Nicholas's reading of the Qur'an. Thus, by arguing that the Qur'an presupposes the Gospel's truth, Nicholas simultaneously modifies his perception of Muslims by insisting on their ignorance.

\section{B Marsilio Ficino}

In the De Christiana religione of Marsilio Ficino (1433-1499) we can also clearly see the influence of the $c L S$, as Angelo Michele Piemontese asserts:

The Contra legem Sarracenorum is the main source for Marsilio Ficino about Muhammad and the Qur'an in the De Christiana religione (1474), in particular chapters Twelve and Twenty-six. In chapter Two Ficino quotes his source. ${ }^{71}$

Furthermore, the De Christiana religione is not the only text where Ficino tackles the issue of Islamic culture. As Bisaha notes:

In October 1480 Marsilio Ficino, the Florentine humanist and Neoplatonic scholar, wrote a letter to Matthias Corvinus of Hungary entitled "An exhortation to war against the barbarians." Ficino implores Matthias to help and save Italy and all of Christendom from the ravages of the inhuman Turks. He chose to emphasize the damage the Turks had done to learning. ${ }^{72}$

This theme (of the Turks as 'barbaro,' or 'uncivilized') is repeated also in De Christiana religione. Though the premises of Ficino's philosophy might seem

71 De Christiana religione, in Marsili Ficini Florentini, Opera quae hactenus extitere et que in lucem nunc primum prodiere omnia, Basileae, ex officina Henricpetrina, MDLXXVI, ed. Mario Sancipriano, vol. II (Turin: Bottega d'Erasmo, 1983). On Ficino and his work De Christiana religione, see Sebastiano Gentile and Stéphane Toussaint, Marsilio Ficino: fonti, testi, fortuna: atti del convegno internazionale (Firenze, 1-3 ottobre 1999) (Rome: Edizioni di storia e letteratura, 2006). See also Giuseppe Saitta, Marsilio Ficino e la filosofia dell'umanesimo (Bologna: Fiammenghi \& Nanni, 1954); Paul Oskar Kristeller, Marsilio Ficino and his work after five hundred years (Florence: F. S. Olschki, 1987); and Cesare Vasoli, "Per le fonti del De christiana religione di Marsilio Ficino," Rinascimento 38 (1988): 135-234.

72 Bisaha, Creating East and West, 74. 
open to a religious exchange, as will be discussed below, this treatise clearly displays the opposite tendency.

According to Ficino, the soul is the fixed center of the world, and links everything in a concrete unity. ${ }^{73}$ From this, he moves to develop an original theory of natural religion, which is deeply rooted in man, and distinguishes men from animals. ${ }^{74}$ The philosophical doctrine is meant to show the truths of religion with theoretical arguments. ${ }^{75}$ Although Ficino bases these arguments on the concept of natural religion, which would seem to make all religions equal, he firmly asserts the superiority of the Christian religion. Indeed, he tries to defend Christian theology, a project that he undertakes in his major apologetic work, De Christiana religione. In the first part of the work, in addition to his famous remarks on the relationship between philosophy and religion, he explains how the authority of the Christian religion can be justified with good reasons against the Jews and Muslims. ${ }^{76}$

In his library, Ficino had a Qur'an translated into Latin as well as other texts from the Islamic tradition (e.g., Avicenna's writings), and he had the CLS of Riccoldo. Indeed, Ficino's works echo several arguments found in Riccoldo's $C L S$, including the disorder and fabrications of the Qur'an, and the violence of Muhammad. Furthermore, Ficino states that this fiction that is the Qur'an is credible among foolish people such as the Muslims, and has spread through violence and deception (a theme from $C L S$ ), since it seems ridiculous to intelligent and wise men. Here we can note a difference between Ficino and Riccoldo: although Riccoldo also describes Muslims as unlearned people, Ficino considers ignorance to be their primary fault.

In chapter twelve of the De Christiana religione, Ficino writes that although Muslims may seem Christian, they are in fact heretics or Arians or Manicheans: "We conclude that Jews, Muslims, and pagans recognize the Christian religion as the most excellent above all." He then adds: "Although these people prefer their doctrine, however, they put the Christian religion before all the others." ${ }^{77}$ Therefore, if a Muslim were to judge with sincerity, he would prefer the Christian religion without doubt. In this case Ficino uses the same rhetorical strategy of Cusanus, namely, the praesuppositio: Muslims must recognize that

73 Paul Oskar Kristeller, Il pensiero filosofico di Marsilio Ficino, Italian translation (Florence: Sansoni, 1953). See also Paul Richard Blum, Philosophy of Religion in the Renaissance (Farnham: Ashgate, 2010), 109-27.

74 Kristeller, Il pensiero filosofico di Marsilio Ficino, 344.

75 Kristeller, Il pensiero filosofico di Marsilio Ficino, 345. Bisaha, Creating East and West, 172.

76 Bisaha, Creating East and West, 265.

77 Marsilio Ficino, De Christiana religione, chapter twelve. 
the Truth is the Christian truth, since rational thinking necessarily leads to this conclusion. Unlike the $c L S$, Ficino insists that Quranic statements confirm the truth of the Gospel, and he uses this argument to affirm that Muslims should then accept Christianity. He emphasizes that Muhammed himself recognized the affinities between Islam and Christianity, and that this is a sign of the Gospel's superiority, since only ignorant people would disregard these similarities and believe instead that Muhammed was the last Prophet and not Jesus.

By using the rhetorical device of 'praesuppositio', Ficino aims to prove that there is only one truth, the truth of the Gospel, and that it is impossible to make any other comparison without starting from this presupposition. Like Cusanus, he uses the praesuppositio to claim that the Quran's author Muhammad perversely subverted the Gospel's order of truth. For this reason, some parts of the Qur'an deviate from the points where it agrees with the Christian text.

We can therefore note Ficino's insistence on the ignorance of Muslims, as well as his description of them as 'barbarians.' Moreover, like Cusanus, Ficino uses the praesuppositio to insist on the affinities between Muslims and Christians, and to highlight how Muslims are really Christians but simply refuse to recognize this. Although Ficino drew many themes from $C L S$, they are nevertheless modified in his work, since his perception of Islam is focused less on the dangers that it poses, and more on the ignorance of Muslims.

\section{Conclusions}

In conclusion, by comparing the works of six authors, I have been able to highlight some themes in Christian apologetic treatises, in order to show how the perception of Muslim culture changed over time. The different ways of writing on Islam are quite clear: whereas Riccoldo considers Muslims as enemies, Ficino describes them less harshly as 'those who do not know.' Thus, the main point shifts to an insistence on the ignorance of Muslims - a modification that is also noticeable in the works of other authors, such as Piccolomini. ${ }^{78}$

78 A debate on the source of his Letter to Mehmed II is still open. I support the thesis of the use of Contra Legem in the work of Pius II; see Costigliolo, Islam e Cristianesimo, 120-21. For essays on Islam and Piccolomini, see Luca D'Ascia and E. Mecacci, eds., Conferenze su Pio II nel sesto centenario della nascita di Enea Silvio Piccolomini (1405-2005) (Siena: Accademia senese degli intronati, 2006). See also Luigi Totaro, ed., Pio II nei suoi Commentarii, un contributo alla lettura della autobiografia di Enea Silvio de Piccolomini 
As demonstrated by the wide circulation of Riccoldo's work, humanists inherited a medieval perception of Islam, which has since been carried forward into modern Western thought. ${ }^{79}$ Because $C L S$ was the main source about Islam for Christian authors throughout the centuries, it is essential to uncover how this work was used, as well as identify its translations and assess its influence on the course of history. Riccoldo wrote the $c L S$ in light of his long experience in an Arabic-speaking country: throughout the work he appears to be angry and continually fighting against Islam, with no hope that Muslims would accept Christianity ${ }^{80}$ In the space of one century, however, the perception begins to change, and Christian authors, both Catholic and Orthodox, study Islam from a different perspective. Islam is no more the enemy but the 'other'something that can be controlled and must necessarily be converted to Christianity. Here the work of George of Trebizond is extremely important for two reasons: it shows the change from a medieval to a humanist perception, as well as the development of a more unified discourse of European civility, contrasted with an Islamic barbarism. ${ }^{81}$

Regarding this last aspect, it is important to note that over the course of time fewer Italian scholars traveled to Byzantium, largely because Byzantine Greeks were coming to Italy in increasing numbers. "A combination of pressure from the Turks and growing opportunities in the West led many Greeks to leave their homelands in search of employment in Italy, while others relocated to different areas of Greece and Venetian Crete." ${ }^{22}$ The work of Trebizond and others such as Bessarion, Plethon, and Kydones is an important indication of this tendency.

According to Edmund Reiss, ${ }^{83}$ the literary and philosophical production of the Middle Ages is consistently characterized by strong polemical intentions.

(Bologna: Patron, 1978). Studies on the centrality of Humanism in Piccolomini's works can be found in F. Nevola, ed., Pio II Piccolomini: il papa del Rinascimento a Siena: atti del convegno internazionale di studi, 5-7 maggio 2005 (Colle Val d'Elsa: Protagon, 2009).

79 Bisaha, Creating East and West, 41.

8 o About the emotions of Riccoldo about Islamic expansion, see René Kappler, trans., Epistolae ad ecclesiam triumphantem, Riccold de Monte Croce, Pérégrination en Terre Sainte et au Proche Orient, Lettres sur la chute de Saint-Jean d'Acre (Paris: H. Champion, 1997); for the Italian translation, see Davide Cappi, ed., Libro della peregrinazione; Epistole alla Chiesa Trionfante (Genova-Milano, 2005).

81 Bisaha, Creating East and West, 44. See also Weiss, La scoperta dell'antichità classica nel Rinascimento.

82 Bisaha, Creating East and West, 140.

83 Edmund Reiss, "Conflict and its Resolution in Medieval Dialogues," in Arts libéraux et philosophie au Moyen Age, Actes du quatrième Congrès international de philosophie médiévale (Paris: Vrin, 1969), 863-872. 
As a matter of fact, disputes, apologetic treatises, polemical libels, and similar texts converged in the literary genre of 'dialogue.' In fifteenth-century political and social life, religious problems were hardly separable from the political context; thus, they were particularly thorny everyday issues for both scholars and the mighty of that age. Dialogue between different religions was therefore an urgent and topical matter on which authors debated, putting forward a variety of philosophical, theological, and political arguments. Nevertheless, the medieval genre of 'dialogue' was constructed through paraphrases, quotations that were frequently unattributed, and a range of textual misinterpretations that often depended on unreliable sources and inaccurate translations of original texts.

According to Thomas Burman, the translations of the Qur'an that circulated in Europe until the eighteenth century show evidence of a deep interest among Western scholars in the Islamic world, despite the translations' many inaccuracies. ${ }^{84}$ Based on these translations and polemical works on the Qur'an, it finally became possible to start weaving an intercultural and interreligious dialogue. Even a polemical and apologetic work can be considered a form of interreligious dialogue, since it is constructed with a continuous comparison of the essential texts and themes of two monotheistic religions, namely, Christianity and Islam.

As mentioned above, Bartolomeo Picerno re-translated the $c L s$ from Greek back into Latin as a gift for Ferdinand II, who in 1492 conquered the kingdom of Granada; furthermore, Bartolomeo's letter invites the king also to liberate Jerusalem and the African countries from Muslim control. In the sixteenth century, anti-Islamic propaganda continued to use the $C L S$ as the source of 'inspiration' for fighting the Muslims (for example, through Luther's widely known translation). However, if it is true that dialogue is a sort of mutual knowledge, then it is also true that we can detect a change in this respect during the fourteenth and fifteenth centuries. If on one hand the circulation of the texts on the interpretation of the Qur'an (like Riccoldo's work) created a slow but growing knowledge about the similarities and differences between Islam and Christianity, then on the other hand, this textual and theorical comparison also contributed to the formation of a Christian and Western identity that saw itself as the center of Roman and Greek culture, in direct opposition to the 'uncivilized' Turks. This theme must be considered as part of the birth of two polar images: the Turk becomes not only the 'wild beast' but also the barbarian and adversary of learning, while the West finds its own identity through this very contrast with the totally strange 'other.' 
In the Middle Ages, as Christian sources on the Islamic world show, Muslim culture was perceived as extremely threatening. Hence, there were many defenses for Christianity, such as the treatises on the 'mistakes' of the followers of Allah. However, as our analysis has illustrated, over the course of time this textual attitude was modified, and authors aimed to point out the Christian truth in comparison with the 'falsity' of Islamic theology, in order to reinforce Christian identity through the presupposition of its own absolute truth. Thus, the apolegetic aim is gradually replaced by a systematic comparison based on partial translations of the Qur'an. The comparison with the 'other', moreover, becomes the basis for reinforcing identity, in order to demonstrate the truth and consequently the supremacy of one's own theoretical position. The 'other' the Muslim, is no longer the enemy; instead, he takes on the role of the nonWestern, the non-European, the 'something' different and alien. Alongside the forced conversion of Muslims and Jews conducted by the Spanish Inquisition, the works of the authors analyzed above show the Western European passage from a position of fear and open hostility towards Muslims, to a progressive position of supremacy, which finally turns into the disappearance of any notion of an 'other' and a respect for legitimate differences. ${ }^{85}$

85 I dedicate this article to my children, Antonio and Adele. I wish to thank Donald Duclow, who provided crucial support. I thank Ian Levy and Rita Tvrtkovic for their questions and editing. Thanks also go to Thomas E. Burman, Gerald Christianson, and all who participated in the Gettysburg conference on "Christian-Muslim Dialogue in the Late Middle Ages." 


\title{
Juan de Segovia on the Superiority of Christians over Muslims: Liber de magna auctoritate episcoporum in concilio generali 10.6
}

\author{
Jesse D. Mann
}

No discussion of dialogue between Christians and Muslims in late medieval Europe can overlook the contributions of the Spanish theologian Juan de Segovia (ca. 1393-1458). As is now increasingly well known, especially to those interested in Nicholas of Cusa, Segovia initiated an important correspondence regarding Islam with several prominent churchmen (including Cusa) after the fall of Constantinople in 1453 and subsequently produced the first trilingual Quran (Arabic, Latin, and Castilian), which unfortunately has not come down to us. ${ }^{1}$ Although the Ottoman conquest of the Byzantine capital surely gave new urgency to Segovia's interest in the 'Islamic question,'2 that interest

1 On Segovia, his correspondence pertaining to the 'Islamic question,' and his trilingual Qur'an, see Rudolf Haubst, "Johannes von Segovia im Gespräch mit Nikolaus von Kues und Jean Germain über die göttliche Dreieinigkeit und ihre Verkundigung vor den Mohammedanern," Münchener Theologische Zeitschrift 2 (1951): 115-29; Darío Cabanelas Rodríguez, Juan de Segoviay el problema islámico (Madrid: Universidad de Madrid, 1952); R. W. Southern, Western Views of Islam in the Middle Ages (Cambridge: Harvard University Press, 1962), 86-103; James E. Biechler, "A New Face Toward Islam: Nicholas of Cusa and John of Segovia," in Nicholas of Cusa: In Search of God and Wisdom, ed. Gerald Christianson and Thomas M. Izbicki (New York: Brill, 1991), 185-202; Anne Marie Wolf, Juan de Segovia and Western Perspectives on Islam in the Fifteenth Century (Ph.D. diss., University of Minnesota, 2003); Victor Sanz Santacruz, "Juan de Segovia y Nicolás de Cusa frente al Islam: su comprensíon intelectualista de la fe cristiana," Anuario de Historia de la Iglesia 16 (2007): 181-194; Thomas E. Burman, Reading the Qurān in Latin Christendom, 1140-1560 (Philadelphia: University of Pennsylvania Press, 2009), 178-197; Walter Andreas Euler and Franz-Bernhard Stammkötter, "Johannes von Segovia und Nikolaus von Kues im Gespräch über den Islam," in Cusanus und der Islam, ed. Walter Andreas Euler and Tom Kerger (Trier: Paulinus, 2010), 49-63; and most recently, Juan de Segovia, De gladio divini spiritus in corda mittendo Sarracenorum: Edition und deutsche Übersetzung, ed. Ulli Roth, 2 vols. (Wiesbaden: Harrassowitz, 2012) [hereafter Roth, De gladio].

2 On the significance of the fall of Constantinople, see Erich Meuthen, "Der Fall von Konstantinopel und der lateinische Westen," Mitteilungen und Forschungsbeiträge der Cusanus-Gesellschaft 16 (1984): 35-6o, esp. 58-6o. 
long antedated $1453 \cdot{ }^{3}$ We also know that Segovia and Cusa shared their mutual interest in Islam while they were together at the Council of Basel in the 1430 s. $^{4}$

Until recently, scholarly attention has primarily focused on Segovia's correspondence with Cusa, Jean Germain, and Aeneas Sylvius Piccolomini. ${ }^{5}$ Now, however, scholars are studying and editing Segovia's other writings on Islam, as the work of Ulli Roth attests. ${ }^{6}$ Santiago Madrigal has also rightly observed that even in works seemingly unrelated to Islam, such as his Liber de magna auctoritate episcoporum in concilio generali, Segovia occasionally addresses issues pertaining to Christian-Muslims relations. ${ }^{7}$ Indeed, it is a chapter from this work that concerns us here.

Of course, what has particularly stimulated modern interest in Segovia's views on Islam is his seeming openness to dialogue with Muslims, which he repeatedly calls "the way of peace and doctrine rather than the way of war." Regardless of whether Segovia's dialogic and pacifistic approach to Islam

3 For examples, see Wolf, "Juan de Segovia," 111ff.; Burman, Reading the Qur'an, 179; and Santacruz, "Juan de Segovia," 184. See also Roth, De gladio, 1: xxx-xliii.

4 See Biechler, "A New Face," 189; and Santacruz, "Juan de Segovia," 183.

5 Davide Scotto's recent doctoral thesis (Florence, 2012) on this correspondence, which I was unable to consult for this article, should provide a better textual foundation for further study of this correspondence.

6 See, e.g., Roth's edition cited above (n. 1). See also the recent improved edition of Segovia's prologue to the trilingual Qur’an by Jose Martínez Gázquez, "El Prólogo de Juan de Segobia al Corán (Qur’ān) trilingüe (1456)," Mittellateinisches Jahrbuch 38 (2003): 389-410.

7 Santiago Madrigal Terrazas, "Lex Christi, lex Moysi, lex Machometi: Juan de Segovia y la polémica anti-islámica," in Umbra, imago, veritas: homenaje a los profesores Manuel Gesteira, Eusebio Gil y Antonio Vargas-Machuca, ed. Secundino Castro et al. (Madrid: Universidad Pontificia Comillas, 2004), 339-365; and idem, "Judíos, moros y cristianos: La vision teológica de Juan de Segovia (1393-1458) acerca de las tres culturas ibéricas," in Christlicher NordenMuslimischer Süden: Ansprüche und Wirklichkeiten von Christen, Juden und Muslimen auf der iberischen Halbinsel im Hoch -und Spätmittelalter, ed. Matthias M. Tischler and Alexander Fidora (Münster: Aschendorff, 2011), 489-504. Anne Marie Wolf has also noted this point as evidence of the connection between Segovia's ecclesiological and Islamic writings, see Wolf, "Juan de Segovia," 238-239. According to Rolf De Kegel, the Liber de magna auctoritate (hereafter: $L M A$ ) is the only ecclesiological work in which Segovia discusses Islam. See Rolf De Kegel, ed., Johannes von Segovia, Liber de magna auctoritate episcoporum in concilio generali (Fribourg: Universitätsverlag, 1995), 34.

8 See Wolf, "Juan de Segovia," 222-23; and Biechler, “A New Face," 191. 
derives from Scripture, ${ }^{9}$ from his university background, ${ }^{10}$ from his personal experiences in Spain or Basel, ${ }^{11}$ or from some combination of these factors, this approach has understandably made him attractive to those seeking nonviolent models for Christian-Muslim interaction. As I have argued elsewhere, however, the attractive aspects of Segovia's approach to Islam should not blind us to his ultimate aim, namely the conversion of Muslims to Christianity, ${ }^{12}$ nor to his seemingly longstanding reliance on the traditional and quite negative Western image of Islam and Muslims. ${ }^{13}$

Hence, as Thomas Burman has so ably discussed, Segovia presents us with a fine example of the tension or oscillation experienced by some medieval Christians between hostility toward Islam and a desire to study and understand Islam, or between "polemic and philology."14 While manifest in his work

This is Wolf's argument, see, e.g., her, “Juan de Segovia," iv, 255-257, and idem, "Pleas for Peace, Problems for Historians: A 1455 Letter from Juan de Segovia to Jean Germain on Countering the Threat of Islam," in Religious Conflict and Accommodation in the Early Modern World, ed. Marguerite Ragnow and William D. Phillips, Jr. (University of Minnesota: Center for Early Modern History, 2011), 55-68.

I have myself advanced this view, though not to the exclusion of the others listed here. See Jesse D. Mann, "Truth and Consequences: Juan de Segovia on Islam and Conciliarism," Medieval Encounters 8 (2002): 79-90.

On the Spanish context, see, e.g., Wolf, "Juan de Segovia," esp. chap. 3; idem, "Pleas for Peace," 62-63 (with bibliography); and Gerard Wiegers, Islamic Literature in Spanish and Aljamiado: Yça of Segovia (fl. 1450), His Antecedents and Successors (Leiden: Brill, 1994). Leyla Rouhi's "A Fifteenth-Century Salamancan's Pursuit of Islamic Studies," in Under the Influence: Questioning the Comparative in Medieval Castile, ed. Cynthia Robinson and Leyla Rouhi (Leiden: Brill, 2004), 21-42 is an interesting, but ultimately unconvincing attempt to apply a postmodern analysis to the collaboration between Segovia and Yça Gidelli. For relevant experiences at Basel, see Thomas M. Izbicki, "The Possibility of Dialogue with Islam in the Fifteenth Century," in Nicholas of Cusa: In Search of God and Wisdom, ed. Gerald Christianson and Thomas M. Izbicki (New York: Brill, 1991), 175-183 at 179-180. Segovia himself suggests that the 'success' of Basel's negotiations with the Hussites supported his approach. See Mann, "Juan de Segovia," 88; Roth, De gladio, 1:xlxli; and below, p. 21.

For a fuller discussion of this aim, see Wolf, "Juan de Segovia," 204ff.

13 See Mann, "Truth and Consequences." On this image, see Norman Daniel, Islam and the West: The Making of an Image (Edinburgh: University Press, 196o); and John Tolan, Saracens: Islam in the Medieval European Imagination (New York: Columbia University Press, 2002). Wolf notes that Segovia employs a "pejorative description of Muslims" already in one of his earliest works dating from 1427, see Wolf, "Juan de Segovia," 119. See also Roth, De gladio, 1:xxxi.

See Burman, Reading the Qur'an, 180, 186. 
on the trilingual Quran, this tension also shows itself in Segovia's 'plan'15 to foster debate between Christians and Muslims while simultaneously bemoaning the paucity of worthy Muslim interlocutors and decrying the supposed Muslim contempt for reason and aversion to disputation. ${ }^{16}$ In the words of a modern advocate of honest interreligious dialogue, Segovia often engages "not a real, but a projected other."17 And so we come to the text translated in this chapter.

Segovia's LMA is one of his 'late' works, probably composed after the Council of Basel (1449) but before November $1453 .{ }^{18}$ Although an ecclesiological treatise that seems to represent some modifications of Segovia's previous conciliarist views, ${ }^{19}$ the $L M A$ also contains numerous references to Islam and Muslims. ${ }^{20}$ The most extensive discussion of Islam appears in Animadvertencia 10, chapter 6. Rolf De Kegel has called this chapter the "earliest passage in Segovia's writings in which he treats Islam at such length." ${ }^{21}$ More importantly, De Kegel also notes that this passage contains the central themes of Segovia's

15 Wolf has rightly observed that Cabanelas overstated the coherence or systematic nature of Segovia's 'plan.' See Wolf, "Pleas for Peace," 65, n. 9.

16 These were, of course, traditional Christian criticisms of Islam. See, e.g., Daniel, Islam and the West, 123-124; and Mann, "Juan de Segovia," 85.

17 See David Tracy, Dialogue with the Other: The Inter-Religious Dialogue (Grand Rapids: Eerdmans, 1990), 4.

18 For a critical edition, see De Kegel, $L M A$ (see above n. 7). On the dating of this work, see De Kegel, $L M A$, 31-36. For more on the $L M A$, see Werner Krämer, Konsens und Rezeption. Verfassungsprinzipien der Kirche im Basler Konziliarismus (Münster: Aschendorff, 1980), 248-251; H. J. Sieben, "Basler Konziliarismus konkret (II). Der 'Liber de magna auctoritate episcoporum in concilio generali' des Johannes von Segovia," in Vom Apostelkonzil zum Ersten Vatikanum. Studien zur Geschichte der Konzilsidee, ed. H. J. Sieben (Paderborn: Schöningh, 1996), 157-95; Rolf De Kegel, "Johannes von Segovia und die verfassungsmässige Vereinbarkeit von Papst und Konzil," in Nach dem Basler Konzil: Die Neuordnung der Kirche zwischen Konziliarismus und monarchischem Papat, ca. 1450-1475, ed. Jürgen Dendorfer and Claudia Märtl (Münster: LIT Verlag, 2008), 45-66; and Thomas Prügl, "Herbst des Konziliarismus? Die Spätschriften des Johannes von Segovia," in Das Ende des konziliaren Zeitalters (1440-1450): Versuch einer Bilanz, ed. Heribert Müller (Munich: Oldenbourg, 2012), 153-174, esp. 159ff.

19 See Prügl, "Herbst des Konziliarismus," 159: "Am sichtbarsten änderte Segovia seine frühere Position im LMA."

20 For examples, see Madrigal, "Lex Christi," 350-355; and Wolf, "Juan de Segovia," 238. De Kegel, "Johannes von Segovia und die verfassungsmässige Vereinbarkeit," 63 also notes that about twenty citations from the Qur'an appear in $L M A$.

21 See De Kegel, $L M A$, 34: "Es ist die früheste Stelle in Segovias Schriften, die so ausführlich über den Islam berichtet." 
more detailed discussion of Islam in his subsequent correspondences and in his later tract De gladio divini spiritus in corda mittendo Sarracenorum. ${ }^{22}$ Others, too, have seen the significance of this chapter. ${ }^{23}$

LMA 10.6 is part of Segovia's larger argument that monarchy has always been and will always be the 'political' structure of the Christian church or polity (politia). ${ }^{24}$ In discussing the superiority of this monarchical structure as well as the general superiority of the Christian polity over other 'polities' (including Jewish, Muslim, and pagan), Segovia advances four reasons for Christianity's preeminence. ${ }^{25}$ From these, the fourth reason is that the Christian religion excels in its number of learned men. On this point, Segovia compares Christianity to both Judaism (10.5) and Islam (10.6), but he is especially interested in explaining why the Muslims lack learned men, despite their large population and their extensive political power. ${ }^{26}$

Such is the context and principal aim of LMA 10.6. This brief introduction to the appended translation cannot even attempt to address all the issues raised by this rich chapter. Nevertheless, I should like to offer four observations here.

First, while it clear that Segovia intends to criticize and denigrate Muslims in this chapter, he does not hesitate to criticize Christians as well. He accuses Christians, notably learned Christians, as well as Muslims and Jews, of hypocrisy, of preaching virtue but practicing vice (10.6.9). More significantly, he also suggests that Christians have been woefully remiss in explaining their faith to Muslims, and that this failure has plagued Christianity since the rise of Islam (10.6.6). One should not exaggerate its importance, but this self-criticism in the context of criticizing the 'other' is at least noteworthy. ${ }^{27}$

22 De Kegel, $L M A$, 34. See also idem, "Johannes von Segovia und die verfassungsmässige Vereinbarkeit," 63 .

23 See Meuthen, "Der Fall," 58 with n. 104; the articles by Santiago Madrigal cited above (n. 7) repeat arguments Madrigal first advanced in his book, El pensamiento ecclesial de Juan de Segovia (1393-1458): La gracia en el tiempo (Madrid: Universidad Pontificia de Comillas, 2004), esp. chap. 3; see De Kegel's own subsequent discussion in "Johannes von Segovia und die verfassungsmässige Vereinbarkeit," $5^{2-54}$; and Roth, De gladio, 1:xlii-xliii.

24 See LMA 10.1.1 (ed. De Kegel, 366-67).

$25 \quad L M A$ 10.2.2 (ed. De Kegel, 368).

$26 \quad L M A$ 10.5.5 (ed. De Kegel, 376).

27 Both these self-criticisms echo arguments apparently first made in his 1427 Repetitio de fide catholica. See Wolf, "Juan de Segovia," 122-124. Madrigal published an 'edition' of this Repetitio as an appendix to his El pensamiento ecclesial, 193-225. The corresponding passages are found in Madrigal, El pensamiento ecclesial, 223-224. Madrigal seems to have followed a different foliation from Wolf. Recently, Madrigal discussed a plan to re-edit this Repetitio. See Santiago Madrigal Terrazas, "Juan de Segovia y la transmisión de sus 
Second, Segovia seems especially fond of the four reasons he presents in this chapter as to why Islam has so few learned men (10.6.1-4).$^{28}$ In a somewhat modified form, these same four reasons, which echo traditional Christian criticisms of Islam, reappear in Segovia's letter to Jean Germain (18 December, $1455)^{29}$ and even more interestingly in the De gladio divini spiritus in corda mittendo Sarracenorum (1453-57). ${ }^{30}$ That Juan de Segovia recycled his own arguments is not news. ${ }^{31}$ Intriguing, however, are the varying ways in which he employed these arguments. In the De gladio, for example, Segovia sets his four reasons for the Sarracens' lack of wisdom and understanding (here sapientia and intellectus, not sapientes) within the context of Aristotle's discussion of masters and slaves, or rulers and ruled. ${ }^{32} \mathrm{He}$ concludes that, given their intellectual deficiencies and their indulgence of carnal appetites, Muslims are by nature better suited to be slaves than masters. ${ }^{33}$ This is not the place to pursue this matter further, but only to note that it merits more detailed investigation.

manuscritos: El ejemplo del "Liber de substancia ecclesie," in De la prima a la segunda "Escuela de Salamanca": Fuentes documentales y lineas de investigación, ed. M. A. Pena González (Salamanca: Universidad Pontificia, 2012), 43-53 at 50.

28 Briefly stated, these are: 1) their obsession with venery; 2) their emphasis on military training and warfare; 3 ) the deleterious effects of the warm climates they inhabit; and 4) their disdain for reasoned debate and for literary pursuits. I think both Madrigal, "Lex Christi," 354, and De Kegel, "Johannes von Segovia und die verfassungsmässige Vereinbarkeit," 53, somewhat misrepresent Segovia's fourth reason when they suggest that, in Segovia's view, Muslims are so occupied with the study of the Qur'an that they consequently neglect other studies. Apart from other problems with this interpretation, Segovia says quite clearly that Muslims do not merely neglect but actively disdain 'studia litterarum.'

29 See Mann, "Juan de Segovia," 85.

$30 \quad$ See Roth, De gladio, 1:358-386, esp. 366ff. (= consideratio 18). I believe Prof. Roth was the first to notice this specific connection between the $L M A$ and the De gladio. See Roth, De gladio, 1:367, n. 26 .

For additional examples of this practice, see Jesse D. Mann, "The Historian and the Truths: Juan de Segovia's Explanatio de tribus veritatibus fidei," 2 vols. (Ph.D. diss, University of Chicago, 1993), 1:171, 270.

See Roth, De gladio, 1:364-366. Cf. Aristotle, Politics, 1252b-1255b. This seems to be a littlestudied instance of Segovia's use of Aristotle. On the general theme, see H. J. Sieben, "Aristotles bei Konstanzer und Basler Konziliaristen," in Vom Apostelkonzil zum Ersten Vatikanum. Studien zur Geschichte der Konzilsidee, ed. H. J. Sieben (Paderborn: Schöningh, 1996), 196-222 at 214-216.

33 Roth, De gladio, 1:366.120-126: "Quomodo autem Sarracenis natura magis servos quam dominantes esse conveniat, illis presertim, a quibus incepit secta, Machometus ipse omnifariam testis est, cum persaepe affirmet gentem, ad quam missus est, ineruditam et insciam esse legendi scribendive ac rudem, quin immo et scientiae incapacem, sed et 
Third, lest we forget that LMA 10.6 aims to emphasize the superiority of Christians over Muslims, toward the end of the chapter (10.6.13) Segovia asserts that the real leaders in many Muslim communities, including even the military leaders, are apostate Christians. In so doing, he seems to show some familiarity with the devshirme, the obligation to surrender Christian children to be raised as Muslims in Ottoman state service, often as Janissaries. ${ }^{34}$ To wit, Segovia speaks of the exalted status such 'apostates' have achieved in Muslim society, and describes the lengths to which some Muslim parents would go to have their own children included among these 'renegades.' Modern scholars have noted that recruits from the Christian levy did indeed obtain some of the highest offices in the state, and that Muslim parents grew envious of these Christian converts. ${ }^{35}$ Precisely how Juan de Segovia might have known about the devshirme I cannot at present say. And one cannot completely exclude the possibility that Segovia is here simply embellishing the polemical commonplace that the Muslim elite is secretly Christian, ${ }^{36}$ though this seems less likely. In any case, Segovia's point is clear enough: even in military matters, where Islam seemingly surpasses Christianity, there too the Christians are deemed superior to the Muslims.

My final observation does not pertain directly to LMA 10.6; however, it is germane to the theme of interreligious comparison that marks this entire chapter. Before undertaking his comparison of Christianity with Islam, Segovia had noted that there are some differences between Christianity and all other religions or 'polities' (including Islam) that render comparison impossible. One such incomparable difference is Christianity's 'end' ( finis). Accordingly, Segovia writes:

No attempt will be made to compare Christianity's manifold superiority in other matters where one cannot properly speak of 'superiority', since [Christianity] and the other religions (politiae) do not share a common

compendii gratia restringens se pro modo calamus alias explicare rationes commemorat dumtaxat notissimas cuilibet intueri volenti quattuor causas, quare Sarraceni a magnitudine deficiant sapientiae et intellectus..."

34 On the devshirme and the Janissaries, see V. L. Ménage, "Devshirme," in Encyclopaedia of Islam, 2nd ed. See also Godfrey Goodwin, The Janissaries (London: Saqi Books, 1997), esp. chap. 3; and Robert Elgood, The Arms of Greece and Her Balkan Neighbors in the Ottoman Period (New York: Thames and Hudson, 2009), 33. I owe to Rita George-Tvrtkovic and Christine Isom-Verhaaren the suggestion that Segovia may be alluding to the Janissaries here.

35 See Goodwin, Janissaries, 35; and Elgood, The Arms of Greece, 33.

36 On this view, see Tolan, Saracens, $25^{2}$ (citing Riccoldo da Montecroce). 
ground. Such, for example, is Christianity's end, namely the attainment of eternal beatitude and direct vision of God. For, as was explained [above] in the fourth consideratio, no other society (societas) shares in this end. ${ }^{37}$

This may not be quite the same as saying extra ecclesiam salus nulla est, but it is not too far from a similarly exclusive view about salvation. Such a view of the way to salvation helps explain why, in $L M A$ 10.6.12, Segovia states that the goal of engagement with Muslims is "to endeavor to save their souls." 38 Just as ecclesiology is, for Segovia, ultimately a matter of soteriology, ${ }^{39}$ so too is dialogue with Islam ultimately a matter of the salvation of souls. No wonder, then, that Segovia puts this important discussion of Christian-Muslim relations in one of his mature ecclesiological works-a work in which he also suggests that a general council could be an appropriate place for Christians and Muslims to discuss their differences. ${ }^{40}$

37 LMA 10.2.2 (ed. De Kegel, 368 ): "Nec fit comparacio de aliis multis preeminenciis eius, in quibus proprie non dicitur excellere, cum cetere policie non sint illorum participes, pote de fine, qui est eterne assecucio beatitudinis in faciali Dei visione constitute. Huius quippe finis, prout in quarta consideratione fuit explanatum, experte sunt cuncte alie societates." Segovia's terminology is notably not uniform here (politia, societas, lex, etc.). LMA 10.6.12 (ed. De Kegel, 382): “... operam dare ad salvandas eorum animas.” Here again, Segovia's position is reminiscent of views expressed in his Repetitio de fide catholica. See Anne Marie Wolf, "Juan de Segovia and the Lessons of History," in In the Light of Medieval Spain: Islam, the West and the Relevance of the Past, ed. Simon R. Doubleday and David Coleman (New York: Palgrave, 2008), 33-52 at 33.

39 On this point, see Jesse D. Mann, "Refuting the Pope: Comments on Juan de Segovia's Gloss on the Bull Etsi non dubitemus," Annuarium Historiae Conciliorum 37 (2005): 323340, esp. 340.

$40 \quad$ See LMA 11.37.3 (ed. De Kegel, 605). For the context of this suggestion, see Sieben, "Basler Konziliarismus konkret," 189; and De Kegel, "Johannes von Segovia und die verfassungsmässige Vereinbarkeit," 62 . For an alternative, but not wholly unrelated view on why Segovia treats Islam in this ecclesiological work, see Madrigal, "Lex Christi," 350-352. 


\section{Appendix \\ A Translation of Juan de Segovia, Liber de magna auctoritate episcoporum 1o. 6 (ed. De Kegel, 377-383)}

Four reasons are provided as to why there is not a multitude of learned men among the Saracens, which is connected to a discussion of how the law of Muhammad saps their strength with blindness.

(§1) The foregoing [chapter] has set out why the Jewish community has contributed, albeit in a limited way, to the support of the Christian faith with a certain multitude of learned men and books. [Now] the reasons must be explained why the Muslim community, despite its large numbers, is not brimming with learned men, or at least has very few. First of all, the most obvious reason is that the Muslims are excessively given to carnal desire. Acts of venery completely distract [their] minds from the height ${ }^{41}$ of mental reflection that is essential for and of great necessity to the growth of knowledge. Wherefore, as Jerome teaches, it is a salutary remedy for scholarly men "to love the science of Scripture in order not to love the vices of the flesh" (Ep. 125.11). The Saracens, however, have the liberty according to their law to take numerous wives; and, as many of them inhabit warm regions, they continuously devote themselves to erotic deeds or, to put it more aptly, to venereal passions. For not satisfied by intercourse with women, many of them burn "with desires for each other, men committing shameless acts with men" (Rom 1:27). Nor is this point undercut just because certain Christians, among whom there are many wise men, may also be charged with this [crime], since such ones are said to be very few, and they hardly dare to commit this outrage even in secret. Moreover, these Christians are not at all interested in wives so that, except to produce offspring, they are hardly said [even] to engage in intercourse. Those considered most learned are rarely or never accused of this terrible crime. But the Saracens, who have many children, burn greatly with that heinous crime and even permit public brothels of adolescent youths. Consequently, since they love vices of the flesh too much, they do not at all apply themselves to the study of Scripture. Book II of Maccabees recounts the story [that] impious Jason made use of this very evil, indeed, one might even say, diabolical stratagem [when] he tried to convert his coreligionists to the Gentile rite so that they might forget God's law and stray from all moral discipline. Under the citadel of Jerusalem he established a gymnasium, and "he put the noblest youths in brothels" (2 Mc 4:10, 12).

\footnotetext{
* I should like to thank Bernard McGinn and Tom Izbicki for their helpful suggestions. As will be evident, this translation is more literal than literary. 
(§2) Here is the second reason why the Muslims do not enjoy an abundance of learned men, a situation excused - indeed commanded — by their law. For among all the commands contained in the Qur'an one very frequently finds that good men are required to go to war, and the exhortations toward this end are quite numerous. Consequently, the Qur'an regularly reproves indolence and cowardice. We see, however, that certain [religious] orders that are trained to fight against infidels produce few literate men, while the Mendicant orders that were established to preach do [produce such men], since the training of the military orders was not geared toward knowledge, as was the case with the Mendicants, but rather toward military ends. Since, therefore, the religion of Muhammad so zealously incites Muslims to fight against Christians, whom they call 'unbelievers,' wanting to fulfill this commandment, the Saracens prefer to devote themselves to military training rather than to study. Their concern is not so much to abound in a multitude of learned men as in a multitude of [military] victories.

(§3) Furthermore, the nature of the regions where the Saracens dwell provides a clear indication [of] why there should be a lack of learning among them. For those regions are very hot and thus not so conducive to the study of sciences, while the regions where the Latins live are neither [very] hot nor very cold, but rather cool. For knowledge is gained by intense consideration that requires a collectedness of spirit; however, it is characteristic of heat to melt and of cold to break down. Thus, we know from repeated experience that in universities and schools, students who learn in winter rather than in summer succeed. The proof of this is that both in the time of the pagans and of the Christians, the vast number of books was not written by those residing in very hot places, but rather by those residing in cool places, with the exception of those areas that are near the coast and thus tempered by the coolness of the sea air. So we see that the Saracens who live among the Christians, although very few in number, have an aptitude for learning sciences provided they abstain from venery.

(§4) The final reason for the lack of learning among the Saracens, at least as regards the study of their law, [is] that being strong in numbers, they do not think it worthy to debate according to reason, and thus they do not so much neglect as contemn the study of letters. And this has been the case since the beginning of that sect. Consequently, by this very fact they show themselves [to be] devoid of truth. They are only willing to defend themselves with an armed multitude so that by means of that multitude they might defeat those whom they cannot overcome by reason.

$(\S 5)$ This defect of theirs in no small measure helps the Catholic faith. For if, like the Jews, the Saracens were willing to engage in debate, since they are so numerous, they would perhaps frequently change the minds of many faithful [into] thinking that they 
are on the side of truth. But since they avoid debate, they serve to strengthen the faith of Christians. They avoid debate when they come together with others [i.e., nonMuslims] not, as many believe, because their law so mandates-for the law of Muhammad in Surah 38 actually exhorts all men of laws (except the evil ones) to speak and dispute always with respectful words - but rather, Muslims avoid debate perhaps, nay rather undoubtedly, because their priests fear being confuted. Whoever carefully observes the Muslim religion will find that it is not so much malice as blindness that causes it to deviate so strongly and fundamentally from the law of grace. To wit, Islam asserts that Christians believe that the Son and the Holy Spirit are like companions or consorts of God. It asserts that the Son and Holy Spirit are 'participants' in deity and that [Christians] worship them [as such]. If this were in fact the case, then Muslims would rightly ridicule Christians as they [now] do, calling them 'worshipers of the companions or participants of God.' For they say that none but the one sole God should be worshiped [and] that sect thinks that Christians worship Father, Son, and Holy Spirit as if they were three essentially different gods.

(§6) Now in truth it would appear that much work must be done so that the Christian faith might be cleared of this abominable calumny. For the failure to expound the doctrine and to demonstrate that such was not the case was greatly detrimental from the beginning of that diabolical sect that blasphemes the Christian faith to such a degree, because they are unable to understand that the three persons [of the Trinity] are one and the same God. Note, however, that I have said 'unable' not 'unwilling.' Indeed, it greatly appears from the tenor of that religion ${ }^{42}$ that smallness of intellect and dullness of mind have been largely responsible for its propagation.

$(\S 7)$ And just as they failed on account of blindness in regard to the mystery of the Trinity, so too [they have failed] in regard to the mystery of the Incarnation. For they consider it impossible that God should have taken on human form. They do not know or do not want to declare that God took on not the person but rather the nature of humanity.

(§8) Likewise, the book of the Qur'an, which makes mention of this point more than fifty times, speaks so equivocally and variously that it frequently contradicts itself; and as proof that [their] religion is true, it expressly alleges that all the devils of hell could not compose so much as even a single one of its very complicated chapters.

42 Here, as elsewhere, I have translated lex as 'religion' rather than 'law' when context and sense suggest and justify such a translation. 
(§9) In the same way it speaks most confusedly about the Gospel, the books of Moses, of David, and of the other prophets because, rightly wanting to defend their religion, they hate the light. Actually, one can understand these four books clearly, indeed concretely, through learned reasoning. All Muslims, to the extent that they are learned in their law, indeed the more learned they are, the more clearly [they] understand that their religion lacks any basis in authority or reason. What happens to them, just as Augustine says of the philosophers in his book Devera religione (1.1), is that they understand one thing and do another. Indeed, the philosophers understood that those 'gods' worshiped in the temples were not really gods; but not wanting to contravene the common error, they venerated them [anyway] along with the [entire] population. Even the Apostle did not pass over this crime in silence, saying that they "suppress the truth of God in wickedness" (Rom 1:18). The learned among the Jews were not free from reproach of this type. For while preaching that one should not steal, they themselves stole; and while preaching to others that one should avoid adultery, they themselves committed adultery; and while [supposedly] abhorring idols, they themselves committed sacrilege. In general: those who instructed others did not instruct themselves. Of course, many learned men in the Christian religion are entangled in that vice. As the Apostle testifies, their minds and consciences are befouled, because, trusting themselves in [their] words, they deny God in [their] deeds. Thus they become abominable and disbelieve "and reject every good work" (Ti 1:15).

(§10) Surely, therefore, if such is the case among learned Saracens, [then] as the old proverb says, "believe the one with experience in the matter." Those who wish to meet and debate with Muslims must have at the ready reasons and arguments [for] why, with the coming of the law of grace, the law of Moses had to cease, and [why] the one law does not support the other but rather constitutes an obstacle to its observance. That most evil sect glories in this, namely that it has mixed together the law of Scripture and the law of the Gospel. Properly speaking, it has made a pastiche, preserving neither law but rather destroying both. Thus, once one has established the incompatibility between the law of grace and the law of Scripture, [i.e.,] the law of the Gospel and of Moses, by this fact the bond of that mixture disappears, and the one wanting to sustain it sees its foundation crumble. [Then], because he believes that these two laws were given by God, unless he is quite shameless, he necessarily must adhere to the law of the Gospel. And for the Muslims, who find the rites and condition of the Jews especially odious, it is no mean step, once they understand these things, to prefer living under the law of the Christians after they have heard an explanation of the truths that especially belong to the catholic faith from which they shrink, thinking [Christians] to be worshipers of the Son and Holy Spirit, not as if one with God the Father, but as if companions or associates in deity. 
(§11) Moreover, they also judge it to be impossible that God's son should be the son of Mary. They are unable to understand that great love by which "God so loved the world that he gave his only begotten Son so that all who believe in Him should not die but have eternal life" (Jn 3:16). Likewise, they misunderstand the Passion, thinking only in human terms that a father whose son has been condemned to prison would beseech the judge and offer him gifts and even kiss his hands, as they say, that the judge might free his son. They therefore consider the Christian faith stupid for affirming such things. Additionally, since Christianity involves eating Christ's body and drinking His blood, the Muslims ridicule the Christians for 'eating' their God and for forgiving men's sins and for other such things they consider absurd. But this misapprehension is due solely to a lack of understanding. For when one explains the mysteries of faith to them, they are stupefied and, conscious of their ignorance, they admire those who explain these mysteries. Consequently, anyone having honest discussions with them has profound pity on the ignorance of the Muslims that derives from their lack of thorough instruction, as well as on their blindness that seeks in so many things to be illuminated.

(§12) There is one point we cannot pass over in silence, namely that for three hundred years now numerous Christian armies have made expeditions against the Muslims both by land and by sea. They have achieved very little in regard to the intended goal of liberating the Holy Land and of exterminating Muhammad and his followers. Rather, these expeditions have greatly harmed the Christian religion. And today, with the Muslims so numerous and the way of war so difficult, it would perhaps not be useless nor ill-advised to try another way to win them over. For an enemy is not always conquered by the sword, but often by many other means, and this would be the greatest victory: to endeavor to save their souls. Have we not seen in our own days that many great armies of the faithful had little success against the Hussites and other heretics of the kingdom of Bohemia, who were going around devastating with fire and sword? But when they agreed to the church's exhortation to examine their differences in a public debate, it was noteworthy that they ceased the persecution they had previously inflicted on the neighboring territories on account of their errors. Nor did they afterwards boast, as they had previously done, about their widely disseminated letters as if those letters contained the truth and everyone else had erred. ${ }^{43}$

43 Segovia is referring to the debates with the Hussites at the Council of Basel. On these debates, see Johannes Helmrath, Das Basler Konzil 1431-1449: Forschungsstand und Probleme (Cologne: Böhlau, 1987), 353-372; and more recently, Gerald Christianson, "Church, Bible, and Reform in the Hussite Debates at the Council of Basel, 1433," in Reassessing Reform: A Historical Investigation into Church Renewal, ed. Christopher M. 
(§13) We will put off for another time the discussion of the method the church should employ in its debates with the Saracens regarding the aforementioned four points, namely: the mystery of the Trinity, the mystery of the Incarnation, the book of the Qur'an, and of the Gospel and the other books of the sacred canon commemorated therein and similar matters. Would that this may come to pass in our days! However, it was relevant to our purpose to have shown that the community of the faithful exceeds all others in its number of learned men. As the Philosopher teaches, wisdom is the greatest of all joys in the world (cf. Aristotle, Ethics 10). And as Solomon testifies, "wisdom is better than arms" (Ws 6:1). Regarding military strength, which is inferior to wisdom, it is well known that, when one compares the faithful Christian people with the Muslim people in the neighboring regions, apostate Christians constitute the strength and core of their army such that these apostates rule over them. Furthermore, in certain Muslim domains only a renegade Christian can become the ruler. For reliable sources have observed that in numerous Muslim principalities no one except renegade Christians assumes the captainship or [any] offices of higher rank. Wherefore the more astute Muslims who want to comply with this custom have their children baptized so that these children may be judged worthy of such offices. Then when the children are older, they induce or coerce them to abjure the Christian faith so that they might be considered apostate Christians. Thus, when they die, their children succeed to the posts that their parents held. Accordingly, the Muslims themselves attest that [even] in regard to this military strength those marked by the name of Christ are superior.

(§14) Of the other three aforementioned points in which the Christian religion surpasses all others, it is not necessary to say much. They follow directly from this, given the presupposition regarding the number of learned men. For given that the greatest number of learned men is found among the [Christian] faithful, and given that by nature everything strives to preserve itself, in order that this multitude of learned men should not diminish, there should be an increase in the number of universities, libraries, and books, as well as an expansion of the Latin language, which is useful to all these ends. Now given this excellence, namely the multitude of learned men by which the faithful people outshines all others, it is quite clear that the community of God's people was most rightly established from the beginning of the world and will continue in this way forever. As the Philosopher teaches, "it is the mark of the wise man to [establish] order" (Aristotle, Metaphysics 1). "It is in the very nature of wisdom that powerfully links one end to another to order all things well" (Ws 8:1) and give order to the things of the universe, to declare [them to be] from God and to show this to others.

Bellitto and David Zachariah Flanagin (Washington, DC: Catholic University of America Press, 2012), 124-148. 
Whence, since [the Christian religion] outstrips all others in its number of learned men, anyone can very clearly see that the Christian community is most rightly established over all others and indeed that, by virtue of its abounding wisdom, this community is the measure and order of all others. For in any genus whatsoever, that which is first is the measure of the other [elements], and surpasses them in this virtue that the others might imitate in a proportional manner but never fully attain. 


\title{
How to Deal with Muslims? Raymond Lull and Ignatius of Loyola
}

\author{
Paul Richard Blum
}

As a small contribution to the topic of the relationship between Christians and Muslims, I should like to exploit two sources that shed light on it from a late medieval and a Renaissance angle. ${ }^{1}$ One is Raymond Lull's Vita coetanea ${ }^{2}$ and the other is Ignatius of Loyola's autobiography, which was originally referred to as Acta P. Ignatii. ${ }^{3}$ What is peculiar about these sources is that both are non-thematic accounts of the relation of a Christian to Muslims; each is an autobiographical narrative about events that occurred before the author's main career, but which was dictated late in his life. In addition, the narratives are indubitably designed to instruct their followers, as they are written in the third person, which decreases subjectivity and enhances authority. I tend to read the two accounts as deliberate messages about what was important to each author, to the effect that all of Acta may be read as an agenda et vitanda because the narrated facts acquire emblematic meaning. If we keep in mind Ignatius's instruction to visualize the life of Christ (compositio loci), we may as well visualize the episodes of his life for the sake of gaining delight and instruction about our own courses of action. Without further ado, here is a quick summary of the two stories:

1 The title of this article has been deemed provocative by some people. The word 'to deal with' appeared to be demeaning. However, there must have been a suspicion that this 'dealing' might be derogatory because it is about Muslims. Honi soit qui mal y pense. And indeed, both Ignatius and Lull did not think highly of Muslims. Therefore, I want to share the way both converted in their views, in addition to the conclusions we may draw.

2 Raimundus Lullus, Vita coetanea, n. 189, in Raimundi Lullii Opera Latina, ed. Hermogenes Harada, vol. 8, Corpus Christianorum Continuatio Medievalis, 34 (Turnholti: Brepols, 1980), 261-309. English quotations are taken from Anthony Bonner, ed., 'Doctor illuminatus'. A Ramon Llull Reader (Princeton: Princeton University Press, 1993).

3 Acta S. Ignatii in Scripta de Sancto Ignatio de Loyola, vol. 1, Monumenta Ignatiana, series quarta (Matriti: Lopez del Horno, 1901), 31-98 (Spanish). English quotations, cited as Reminiscences, are taken from Ignatius of Loyola, Personal Writings, ed. Joseph A. Munitz and Philip Endean (London: Penguin, 2004); on the production of the autobiography see Introduction, 8-11. 
Raymond Lull's (1232-1315) narrative has to do with his Saracen slave who had taught him Arabic. One day in 1273, he and his slave began to fight after the slave uttered some anti-Christian slurs. While the Saracen was in prison, Lull was tormented by the thought that he might be obliged to kill his teacherservant. When the prisoner had hanged himself, Lull thanked God for sparing him from having to soil his hands. Ignatius of Loyola's account, on the other hand, occurred in 1522, when he encountered a Moor who ridiculed the virginity of St. Mary. Unsure about whether or not to go after him, Ignatius let his mule decide. As a result, he saw it to be God's will to proceed to Montserrat, instead of fighting the Muslim.

In both cases, it is not the wickedness or ignorance of the Muslims that drives the conflict; instead, it is the weakness of the Christians. Let us now take a closer look into the biographical and theoretical contexts of each story, in order to see whether there is a pattern that helps in conceptualizing the Christian-Muslim relationships.

\section{Raymond and the Slave}

There is no need to explain further the structure and origin of the Vita coetanea $;{ }^{4}$ however, what is worth stressing is the fact that it is a narrative of conversion and illumination. ${ }^{5}$ In this narrative construction, the slave episode is located after Raymond had completed a peregrination and had accepted that he would return home instead of going to Paris. When he arrived at home, he tells us, he did three things: he dressed himself in the simplest fashion, he learned Latin (here rather than in Paris), and, "having bought himself a Saracen,

4 Cf. Vita coetanea, 261-263; Erhard Wolfram Platzeck, Raimund Lull. Sein Leben-Seine Werke, Die Grundlagen seines Denkens, 2 vols (Düsseldorf: Schwann, 1962-1964) vol. 2, p. 66*; idem, Das Leben des seligen Raimund Lull. Die 'Vita coetanea' und ausgewählte Texte (Düsseldorf: Patmos, 1964), 21-26. Jordi Gayà, “'De conversione sua ad poenitentiam' Reflexiones ante la edición crítica de Vita Coetanea," Estudios Lulianos 24 (1980): 87-91. Anita Obermeier, The History and Anatomy of Auctorial Self-Criticism in the European Middle Ages (Amsterdam: Rodopi, 1999), 229-231 (nothing on the slave episode). Cf. Domínguez and Gayà, "Life," in Raimundus Lullus. An Introduction to his Life, Works and Thought, ed. Alexander Fidora and Josep E. Rubio, Corpus Christianorum Continuatio Medevalis 214; Raimundi Lullii Opera Latina 2 (Turnhout: Brepols, 2008), 3-124; on the Vita $5^{-8 .}$

5 Mark D. Johnston, "Ramon Llull's Conversion to Penitence," Mystics Quarterly 16/4 (1990): 179-192. 
he learned the Arabic language from him." ${ }^{\prime 6}$ From this, we gather that his role as a hermit and his study of Latin and Arabic are one act.

After that, there follows a lacuna of nine years: "Nine years later, it happened that... his Saracen slave blasphemed the name of Christ." ${ }^{7}$ This gap in time is famous because filling it would provide details about Raymond's education. From the narrative point of view, it is pointless to speculate what he might have been doing during those nine years. In fact, what matters is that Lull refuses to tell us. The plot says: the upshot of nine years of retirement and study was that the slave spoke up against his master. Since the episode ends with the death of the slave, one may even interpret this gap as the effective obliteration of the content of the nine years of formation. ${ }^{8}$

The exact blasphemy regarding the name of Christ is unclear. As an indication, however, one may turn to the narrative in the manuscript Breviculum, which has the merit of giving a historically close interpretation. In this account, the Saracen says: "Christ is fake, because he preached to be God and deified man, and incarnate." ${ }^{9}$ Here is not the place to contemplate the probability that the slave may have uttered something to this effect, because it would require a historical discussion of the Muslim interpretation of Christ. To grasp the implications of the narrative, it is more interesting to look instead at Lull's Christology. His teaching on Christ emphasizes humility. For instance, the

6 Vita coetanea, $\mathrm{n}$. 11 ; Bonner, Doctor illuminatus, 15 . On slaves and Moors in Mallorca at Lull's times, see Domínguez and Gayà, "Life", passim. The question of symbolism in this phase of Lull's life has been raised in Fernando Domínguez Reboiras, "Idea y estructura de la Vita Raymundi Lulii," Estudios Lulianos 27 (1987): 1-20, 12-13.

7 Bonner, Doctor illuminatus, 16.

8 Amador Vega, Ramon Llull and the Secret of Life (New York: Crossroad, 2002), 7. Another possibility is that the elderly Lull, in affirming his authority, wanted to blur over heterodox sources he had studied: Massimo Candellero, "Un importante documento biografico lulliano: la Vita coetanea," Istituto Univeristario Orientale Annali, sezione romana 34/1 (1992) [Atti del Convegno Internazionale Ramon Llull, il lullismo internazionale, l'Italia]: 15-33, $28 \mathrm{f}$.

9 Ramon Llull, Breviculum seu Electorium parvum Thomae Migerii (Le Myésier), ed. Charles Lohr, Theodor Pindl-Büchel and Walburga Büchel, Corpus Christianorum, Continuatio Mediaevalis. Raimundi Lulli Opera Latina. Supplementum Lullianum, 1 (Turnhout: Brepols, 1990), 283-8, 311-356. Here I take advantage of the online edition http://lullianarts.net/ miniatures/mini/BREVo3.HTM, retrieved April 1, 2014, table 3: "Numquid vides, Raimundus, in hoc Alcorano, quod cum scias legere, intelligere et loqui arabicum, quod pulchrius dictamen nec aequale in pulchritudine homo nec angelus possent facere, a quo igitur factum est a Deo solo, et ex quo ergo a Macometo nobis traditus est? Numquid Dei nuntius et propheta dici potest et exaudiri a Deo, cum pro nobis Deum rogaverit in die iudicii? Falsum Christum, qui praedicavit se Deum hominem deificatum, incarnatum, qui dixit Deum tantum et trinum et unum esse?" (my translation). 
Liber contemplationis subsumes Christ's humility under humility as a divine attribute:

Praise and glory and blessing to Your sacred humility; for in the same measure as it is great and admirable through the fact that You willed to descend from the highest good and highness into this world to take on flesh, so the magnitude of haughtiness in us wants to elevate us to the dignities and heights and honors to which we are not entitled. ${ }^{10}$

The Saracen's allegation stands in stark contrast with the theological interpretation of what is known as kenosis, which according to Lull is inversely proportionate to man's arrogance. Elsewhere, Lull emphasizes that God became incarnate not for the sake of human redemption, as often expected, but rather for the sake of self-revelation and consequent love. ${ }^{11}$ This is a theology based on divine dignity and hierarchical imbalance. ${ }^{12}$ Lull suggests remedying exaggerated pride by contemplating God's humble descent into human flesh. In fact, in the following chapter, Lull relates haughtiness to irascibility: "As haughtiness makes humans irascible, boorish, and ill-behaved, so Your [Christ's] humility made man amiable, simple, and well-behaved while You were in this world among humans." ${ }^{13}$ With due fairness, in his Book of the Gentile, Lull has the Saracen interlocutor claim the same divine humility for the Prophet Mohammed, which has been bestowed upon him by God in order to prevent

10 Raimundus Lullus, Liber magnus contemplationis in Deum, tomus 3 (Palma de Mallorca: Cerdà, Antich, Amoròs, 1746), vol. 1, l. 2, dist. 19, cap. 87, n. 13, p. 211: "Tuae sanctae Humilitati sit laus et goria et benedictio; quia, sicut ipsa est magna et mirabilis per hoc, quod voluerit (!) de supremis bonis et altitudinibus Te descendere in hunc mundum ad assumendum Carnem; ita magnitudo superbiae, quae est in nobis, vult nos elevare ad nobilitates et ad altitudines et ad honores ad nos non pertinentes." In Catalan: Ramon Llull, Libre de Contemplació en Deu, ed. Antoni M.a Alcover and Mateu Obrador i Bennássar, vol. 2 (Palma de Mallorca: Comissió Editora Lulliana, 1906), (Obres de Ramon LLull, vol. 3; reprint Palma: Miquel Font, 1989), 152.

11 Tomás and Joaquin Carrèras y Artau, Historia de la filosofia española. Filosofia cristiana de los siglos XIII al XV, vol. 1 (Madrid: Real Academia de ciencias exactas físicas y naturales, 1939), 505-507. Cf. Carles Llinàs Puente, "Angelología y Cristología en Ramon Llull," Studia Lulliana 48 (2008): 41-68; 56-64.

Details in Walter Andreas Euler, Unitas et Pax. Religionsvergleich bei Raimundus Lullus und Nikolaus von Kues, 2nd. ed. (Würzburg-Altenberge: Echter/Oros, 1995), 84-92.

13 Liber Contemplationis, ibid., cap. 88, n. 27, p. 225: "Sicut superbia facit hominem iracundum et rusticum et male morigeratum, ita Humilitas Te fecit esse hominem dulcem et simplicem et suavem et bene morigeratum, quando eras in mundo hominum." Libre de Contemplació, 159 . 
pride and vainglory. ${ }^{14}$ These two sources were composed around the time of the event with the Saracen; later, we see Lull accusing infidels (Jews in this case) of using the name of God 'in vain,' that is, as an accidental description rather than invoking His theological essence. Here, the blasphemy consists of understanding the name of God in human terms. ${ }^{15}$ In his later Disputation with Hamar the Saracen (1308), written a few years before dictating his reminiscences, Lull has the Muslim contrast the absolute attributes of God with the finitude that is entailed in the incarnation. ${ }^{16}$ Lull, the narrator, certainly does not suggest that his slave-teacher had such sophisticated arguments at hand, but he does return to the subject of strife. In the conclusion to the disputation, he notes that the book made use exclusively of "rational arguments rather than authorities, for authorities become acrimonious through conflicting interpretations." ${ }^{17}$ Exaggeration, pride, haughtiness, and concomitant ire surround his Christology, and that is precisely what follows in the autobiographical narrative.

Following the aforementioned incident, Raymond loses his temper (nimio zelo motus) and beats the slave. ${ }^{18}$ The slave, however, resisted — but what made him resist? He grew enraged to the same extent that Raymond had exceeded what was appropriate: "As a result, the Saracen became extremely embittered (rancore nimio inde concepto), and he began plotting against his master."19

14 Lullus, The Book of the Gentile and the Three Wise Men, book 4, n. 3, in Bonner, Doctor illuminatus, 144.

15 Ramón Lull, El “Liber predicationis contra Judeos," ed. José M.a Millás Vallicrosa (MadridBarcelona: Istituto Arias Montano, 1957), de 9.o sermone, p. 87: "Idcirco infideles nomen Dei accipiunt in vanum, eo quia blasphemunt nomina Dei intrinseca, scilicet deitantem, deitatum et deitare. Item infideles accipiunt nomen Dei... quo ad descriptionem, sicut homo qui magis perfecte nominat alium hominem diffiniendo ipsum quam describendo..."

16 Raimundus Lullus, Disputatio Raymundi Christiani et Hamar Saraceni, in Opera, vol. 4 (Mainz: Mayer, 1729) (separate pagination), 2-12. On the specific theology of this work see Hans Daiber, "Raimundus Lullus in der Auseinandersetzung mit dem Islam. Eine philosophiegeschichtliche Analyse des Liber disputationis Raimundi Christiani et Homeri Saraceni," in Juden, Christen, und Muslime. Religionsdialoge im Mittelalter, ed. Matthias Lutz-Bachmann and Alexander Fidora (Darmstadt: Wissenschaftliche Buchgesellschaft, 2004), 136-172; on the Saracen's, view 138-148.

17 Disputatio, 46: “... ut Christianus et Saracenus per Rationes, non per Autoritates, ad invicem disputarent; nam Authoritates calumniantur ratione diversarum expositionum." This does not at all mean that Lull would desist from accusing Muslims from converting Christians, as Lull continues.

18 Vita coetanea, n. 11; Bonner, Doctor illuminatus, $16 \mathrm{f}$.

19 Vita coetanea, n. 11; Bonner, Doctor illuminatus, 17. Peers, following the later Catalan version, has: "Now the said slave was of a very haughty spirit, and further... he had a great 
Charles de Bovelles (1479-1567) broadened this analysis by narrating that the "purchased Saracen feared that Raymond's education might become dangerous for the Mohammedan religion (particularly because he had exacted to be trained in speaking Arabic only for the purpose of preaching)." ${ }^{20}$ While this may be true, Raymond focuses on the equivalence of passions. The question evoked is not about the intentions of the Muslim or the would-be missionary, but the pent-up zeal on both sides.

Consequently, the slave plotted to kill his master. While shouting "You're dead!" he managed to get hold of a sword, with which he attacked and wounded his master. But Raymond overcame the attacker. ${ }^{21}$ While the athletic Franciscan friar Erhard Wolfram Platzeck relished the prowess and strength of his hero, ${ }^{22}$ it appears to be more important that Lull, after so many adventures, still reminds his readers that he had been wounded and that physical violence was needed to stop the assault. Whereas the philosopher emerges from the event physically victorious, he finds himself in a spiritual and moral standoff. Having prevented his household from killing the Muslim, and having locked him up, he subsequently faced a dilemma: ${ }^{23}$ to put him to death would have been severe and harsh, since the culprit was his Arabic teacher, after all; however, to release him appeared too dangerous. Obviously, the dilemma comes from the very same relationship that had led to the fight, namely, that the slave-owner was subordinate to the slave as a teacher, or in other words, the Christian had made himself dependent on the Muslim for the sake of subduing him (or any other version that describes this imbalanced relationship).

If we look at Lull's predicament as a paradigm of a global pattern, we may say: one conundrum encountered in the attitude of the Christian world towards the Muslim world is that any assertion of hegemony depends upon the ability to understand the allegedly lower religion; however, any effort to understand the other religion creates a kind of coexistence in which using violence would be contradictory. This mutual dependency appears to be the result of the most elementary attempt at living with the target of the mission.

wrath at these blows..." (E. Allison Peers, Ramon Lull. A Biography (London: Society for Promoting Christian Knowledge, 1920), 41).

20 Carolus Bovillus, Vita, in Acta Sanctorum, Junii tomus septimus (Paris-Rome: Palme, 1867), June 30, 613-618; n. 5, cap. 2, p. 616A: "Timensque ideo emptitius Saracenus, qui eum docuerat, ne Raemundi doctrina Mahumenticae legi perniciosa fieret (praesertim cum solius praedicationis causa, Arabici sermonis peritia, ab eo se imbui postulasset)..."

21 Vita coetanea, n. 12; Bonner, Doctor illuminatus, 17.

22 Platzeck, Das Leben des seligen Raimund Lull, 152: "Die Szene zeigt uns einen körperlich noch gewandten Raimund, der dazu über beachtliche Kräfte verfügte."

23 This has been carefully analyzed in M. V. Dougherty, Moral Dilemmas in Medieval Thought. From Gratian to Aquinas (Cambridge: University Press, 2011), 94-101. 
In terms of slave-master relationship, we see that the mutual instruction (language traded for Christian education) brings the slave-teacher to hate the master's religion, whereas the master-student is prevented from bluntly exercising his power. Since this leads the slave to take recourse to verbal abuse, the master then falls into violence, which only induces the slave to attempt taking the master's life. At this point, the master gains the upper hand not only by overwhelming the attacker, but, more importantly, by putting an end to the violence. Now, let us see how the story ends.

In his 'perplexity,' Raymond retires to praying to God. In a classic mystical pattern, he is 'sad' about God's persistent silence. Upon returning home, he made a detour to the prison cell in order to see after the captive, and found that his slave had hanged himself with the very "rope with which he had been bound." 24 Obviously, the poor man had no other tool for his suicide, a reader might flippantly remark. Why should Lull remember this detail after forty years? In a symbolic reading, the Muslim was put to death by his Christian host, and yet he agreed to it and participated actively in his defeat. In this sense, he took the weapon out of his master's hand (as the master had extorted the sword from his own hand) and executed himself. We moderns would, of course, expect that upon seeing this, Lull would mourn the loss of his teacher of Arabic. Instead, we learn that Lull "joyfully gave thanks to God, not only for keeping his hands innocent (innoxias) of the death of this Saracen but also for freeing him from that terrible perplexity concerning which he had just recently so anxiously asked Him for guidance."25

According to Michael Dougherty, it is a pattern of the Vita coetanea that Lull ascribes, or even imputes, the solution of moral dilemmas to divine intervention. ${ }^{26}$ In fact, this is consistent with the mystical persona that emerges from the Vita. The solution is external to his actions, and yet, it resolves his conflicting intentions: the blasphemer and attacker is dead without having soiled the missionary's hands.

The next step in the narrative is the divine inspiration of the Ars major. In a symbolic reading, post haec is propter haec. ${ }^{27}$ After retiring for nine years to study Latin and Arabic, the Muslim teacher becomes a threat that is removed by divine intervention, thus clearing the way for the intuition of the new

24 Vita coetanea, n. 13: "inuenit, quod ipse fune, quo ligatus fuit, iugulauerat semet ipsum"; Bonner, Doctor illuminatus, 17.

25 Ibid.

26 Dougherty, Dilemmas, 101.

27 Vita coetanea, n. 14, p. 280: "Post haec Raimundus ascendit in montem quendam..." 
method to convert Muslims with rational arguments. What are we then supposed to learn from this narrative?

- Mission inevitably requires acculturation, that is, immersion in the culture of those who are the intended subjects of conversion.

- Familiarity with the world of the others, however, tends to become mutual: the inherent negation of the culture to be converted will be turned against the missionaries and their haughty behavior. The slave sees through the ruse of the master and consequently emulates him.

- The 'sword' of the sermon therefore tends to fall back into the sword of violence, which is an instantaneous and mutual twist.

- Hence, there follows a predicament of violence and non-violence that cannot be resolved but by external intervention.

- Does this not tell us, regarding mission to non-believers: do not even try?

As we all know, Lull kept trying and advocating — continuously and with endurance - for the usage of both swords. ${ }^{28}$ The Breviculum underscores this through its use of military imagery, even when illustrating Aristotelian and Lullian logic. ${ }^{29}$ Also, to give up mission would indeed end the dialectics of acquaintance and hostility that is at the heart of our episode. One might even argue that the contention in verbal disputations carries out this very dialectic. In the same way as only God could have it both ways, namely, leaving Lull innocent and yet having the attacker killed, it is also God who commands him to try both swords, and not only the militant one. In this dialectical reading, the most troubling sub-dilemma is the death of the Saracen, if we identify him as both the target of mission (manifest in his role as a slave) and the facilitator of the acculturation attempt by Lull (manifest in his role as the teacher). Why must the teacher die? The answer may lie in two details: first, that Raymond did not regret his teacher's death, and second, that Raymond quotes his teacher's threatening remark: "You are dead!" The first point indicates that this is not a novel about sensibilities, but about the dilemmatic structure of mission as such. The second, moreover, says that the religion to be converted must 'die,' or in other words, disappear from the tribulations of the missionary, and only

28 Cf. Paul Richard Blum, Philosophy of Religion in the Renaissance (Farnham: Ashgate, 2010), 1-14, on Lull's advocating the two swords in the sense of conversion by the word and by crusade.

29 See Breviculum, images 6 and 7. 
then is the mission accomplished. ${ }^{30}$ In historical reality, Lull repeatedly travelled to Northern Africa, where he engaged in disputes with Islamic authorities. Eventually, he was attacked and driven out. Despite this, the divine command remains: maintain your innocence! Whether it is possible to remain innocent while subjugating another culture is a question that Lull patently answers in the affirmative. Thus, Lull's way of speaking about God to Muslims is totally independent of the Holy Scripture because it is purely logical; consequently, he hoped his new logic would be apt to convince Muslims of the truth of Christianity, and that is what he kept doing for the rest of his long life. His paradoxical way to teach Christian revelation was based on his personal revelation that there might be a transcultural method of communication, namely, his Lullian art.

\section{Ignatius and the Moor}

Let us now switch to Ignatius of Loyola's encounter with a Moor. ${ }^{31}$ This event happened in 1522, about two hundred and fifty years after Lull. As I previously mentioned, the narrative structure of his account is the same as Lull's: Ignatius is telling, in third person, the story of his own life to a confidant. ${ }^{32}$ Furthermore, both events occur at similar points in each author's life: the saint is also approaching his spiritual and intellectual breakthrough. In the narrative, Ignatius is on his way to Montserrat to pay homage to the Black Madonna. It is here that he inserts the episode of when he met a Moor. The epithet 'moor' may have been derogatory at that time,,$^{33}$ and if so, it was probably intentional because the thrust of the narrative argument is to desist from persecution, as

$30 \quad$ A symbolic interpretation, ventured in Johnston, "Conversion to Penitence," 184, would be: "Ignorant of Divine Truth, they [the Averroist and Muslim audiences] will inevitably destroy themselves and, like suicides, incur eternal damnation." Among the irenic interpretations championing inter-cultural exchange I may mention Berthold Altaner, "Glaubenszwang und Glaubensfreiheit in der Missionstheorie des Raymundus Lullus. Ein Beitrag zur Geschichte des Tolleranzgedankens," Historisches Jahrbuch 47 (1928): 586-610, 591 .

31 For the socio-cultural context, see Marjorie O'Rourke Boyle, Loyola's Acts. The Rhetoric of the Self (Berkeley: University of California Press, 1997), 6o-65. The status of the debate about Saint Mary's virginity in Islamic sources is beyond the scope of my study.

That the words recorded are his is obvious from Louis Gonçalves da Câmara, the secretary who received the dictation and describes in detail Ignatius's design and determination. See Munitz and Endean, "Introduction," in Personal Writings, 4-7. 
we will see. Moreover, already fifty years later when Pedro Ribadeneira (15271611) wrote the first biography of the founder of the Society of Jesus in 1572, he felt the need to explain that there actually lived "Saracens or Moors" in Aragon as remainders of that "ancient tribe." ${ }^{34}$ Daniello Bartoli (1608-1685) also uses the term 'Moresco' in his very popular biography from 1650 , and adds that this person was a Muslim. ${ }^{35}$ From this we are reminded that, from the narrative standpoint of the later Ignatius, the Moor had to be a Muslim for the story to be plausible. ${ }^{36}$

Ignatius emphasizes that it is worthwhile for the episode "to have [been] written, so that people can understand how our Lord used to deal with this soul." This is because the not so young but newly converted man is on his way to Montserrat; however, his soul at the time "was still blind, though with great desires to serve [God] as far as its knowledge went." ${ }^{37}$ And so, with youthful vanity, he dreams of great 'exploits' (hazañas) in the footsteps of the great saints, unaware that his dreams were nothing but 'exterior deeds' devoid of humility and patience, not to mention discernment. ${ }^{38}$ It cannot escape the intended readership that Ignatius is inserting key terms regarding his spirituality. Even after the Moor incident that he is about to recount, Ignatius entertains chivalric fantasies, modeled on the knight errant Amadis that would later be parodied by Cervantes. We shall return to the motif of chivalry. At this point,

34 Petrus Ribadeneira, Vita Ingatii Loiolae...(Matriti: Gomezius, 1586), cap. 3, fol. 8r: "Sarracenus quidam sive Maurus", and he explains: "Erant per id tempus in Hispania Tarraconensi adhuc aliqui ex antiquis eius gentis reliquiis." Cf. Pedro Leturia, Iñigo de Loyola, trans. Aloysius J. Owen (Syracuse: Le Moyne College Press, 1949), 137 f.

35 Daniello Bartoli, Della vita e dell'istituto di S. Ignatio ... libri cinque (Roma: Manelfi, 1650), lib. 1, cap. 9, p. 25: "Un viandante, di stirpe Moresco, e di Religione Maomettano, de quali, in que' tempi era gran numero ne' Regni di Valenza, e d'Aragona..." From these testimonies that are closer to the events than modern interpretations we may gather that, if there was any negative ring in the autobiography, then the early Jesuits clarified the terminology and the historical facts.

36 Boyle, Acts, 61 surmises that at that time the 'moor' must have been a Morisco, i.e. baptized. However, that does not play out in the narrative.

37 Ignatius, Reminiscences, n. 14, p. 18. Acta S. Ignatii, p. 44.: “... será bueno escriuirse, para que se entienda cómo nuestro Señor se abía con esta ánima, que aun estaua ciega, avunque con grandes deseos de servirle en todo lo que conociese..."

38 Ignatius, Reminiscences, n. 14, p. 18-19; "exploits" n. 17, p. 20 (Acta, p. 46). Acta, p. 45: “... no mirando á cosa ninguna interiror, ni sabiendo qué cosa era humildad, ni charidad, ni patiencia, ni discretion..., sino toda su intención era hazer destas obras grandes exteriores..." 
though, we may assume that the irony of Ignatius following the knightly path on a mule may have been narrated on purpose. ${ }^{39}$

During the journey, Ignatius encounters another traveler on a mule, a Moor. The two of them begin conversing about Our Lady. In their exchange, the Muslim accepts the virginity in conception but doubts the possibility that Mary remained a virgin after giving birth, invoking 'natural reasons.' We do not learn what kind of response Ignatius had to offer. ${ }^{40}$ We only see that he loses the argument, which is depicted in the narrative with the image that he lost sight of the speeding Moor. The reported detail that this fellow traveler appealed to natural reasons may have suggested to readers that the Moor was a physician and was therefore capable of arguing as a naturalist. At any rate, the Moor must have been well versed in Christian doctrine.

It is well known that the virginity of Our Lady can only be defended by theological or mystical arguments. A mystical argument has been imputed to Ignatius by the dramatist Pedro Calderón de la Barca (1600-1681).41 Thomas Aquinas, moreover, had adduced a series of theological arguments, based on the dignity of the Mother for the sake of the dignity of the son, Christ. ${ }^{42}$ The Jesuit Francisco Suárez (1548-1617) will later comment on this article and ascribe the blasphemy - specifically that Mary could not remain a virgin after giving birth - to Protestant heretics (not to Muslims), singling out Erasmus of Rotterdam. His discussion of the question regarding her virginity post partum alone extends over four folio pages and invokes a great number of Church Fathers and scholastic authorities, which shows that the Muslim's objection was not at all outrageous. ${ }^{43}$ Jacobus Pontanus (1542-1626), the Jesuit professor in Augsburg, however, poked fun of the issue in the 1580s. In one of his school comedies, the main character Stratocles ridicules classic education by scolding the muse "Lady Calliope, allegedly a virgin (a 'virgin' who gave birth to both

39 Mules were not appropriate for gentlemen, see Boyle, Acts, $53 \mathrm{f}$.

40 Also Ribadeneira has "naturales rationes aliquot" without saying how Ignatius responded (Vita, 8r). Bartoli makes the Moor appear "empio" and arguing "perfidiosamente," to which Ignatius responded "con similitudini, e con ragioni" (Della vita, 26), thus blaming the Moor.

Pedro Calderón de la Barca, El gran Príncipe de Fez Don Baltasar de Loyola, jornada II, esc. 16 compares the birth of Christ with sunlight passing through glass; excerpts in Leturia, Iñigo, $177 \mathrm{f}$.

43 Franciscus Suárez, Commentariorum et disputationum in tertiam partem divi Thomae tomus secundus (Venetiis: Apud Minimam Societatem, 1594), q. 28, art. 1-3, disp. 5, sect. 2, $75^{-78 .}$ 
Linus and Rhesus)." ${ }^{44}$ We may conclude from these parallels that the goal of the narrative was not to expose the content of the blasphemy, but the change of attitude in Ignatius.

Given the careful choice of words in Ignatius's seemingly simple narrative, it may be significant that the narrator refers to himself as 'the pilgrim' at this point, since it is not the charisma of a pilgrim to engage in theological and scientific debates. At any rate, following the incident, he becomes enraged and feels "obliged to stand up for [St. Mary's] honor" and to stab the blasphemer. ${ }^{45}$ Instead of praying explicitly, the Pilgrim follows a pattern familiar to him from his beloved chivalric novels: since the Moor was continuing for a while on their common route but soon would turn off the shared road, Ignatius decided not to decide himself, but let the mule go on a loose rein and choose whichever path it would take. ${ }^{46}$ Ignatius reports that God willed to have his mule choose the path that would spare the Muslim's life. ${ }^{47}$ After this incident, Ignatius proceeded to Montserrat.

With this course of action, the author is employing a chivalric plot device that would have been very familiar to his audience. For instance, Amadis, in the anonymous novel with this same title, had a dream in which his horse, with loosened reins, would carry him out of troubles. ${ }^{48}$ And early in his career as a knight, Don Quixote comes to a crossroads and, undecided where to go and explicitly imitating the knights-errant, lets the horse decide (which then chooses to return home) ${ }^{49}$ Although I have no evidence that Ignatius was aware of it, it is worth mentioning that Raymond Lull, in his book on the Order of the Knights, also discusses the symbolism of the reins, rendering it the following way:

44 Jacobus Pontanus, Soldier or Scholar. Stratocles or War, ed. Thomas D. McCreight and Paul Richard Blum (Baltimore: Apprentice House, 2009), lines 46 f.: "Domina Calliope, quam esse narrant virginem / (Si virgo est, quae Linumque, Rhesumque peperit).” Translation from this bilingual edition; cf. comment, $133 \mathrm{f}$.

45 Ignatius, Reminiscences, n. 15, 19.

$46 A c t a$, n. 16, p. 46: “... no hallando cosa cierta á que se determinasse, se determine en esto, scilicet, de dexar yr la mula con la rienda suelta...”

47 Ignatius, Reminiscences n. 16, p. 19.

48 Vasco Lobeira, Amadis of Gaul, vol. 1 (London: Smith, 1872), book 2, chapter 3, 266.

49 Miguel de Cervantes, El ingenioso hidalgo don Quijote de la Mancha, [1605], I 4; read at http://www.gutenberg.org/files/2000/200o-h/2000-h.htm\#1_iv. Leturia, Iñigo, 140, note 6o, mentions Don Quijote. 
A bridle is put on the horse, and into the hands of the knight the reins are given. This signifies that with the bridle the knight shall bridle his mouth from speaking evil or false words, that he shall bridle his hands not to give so much as to need to beg thereafter, nor shall he be so reckless that his courage becomes mindless. And through the reins he should understand that he shall let himself be guided wherever the Order of the Knights wants to engage or send him. And whenever necessary [...] he should be courageous and not fear his enemies, and if he hesitates to injure them, make it vanish from valor. And if he does the contrary of that, then his horse, which is a beast without reason, will follow the rule and duty of knighthood better than the knight. ${ }^{50}$

This advice is unmistakably Lullian, as it pairs rationality with trust in divine authority. Ignatius adopts a similar attitude that leaves emotional response behind while trusting the wisdom of the beast.

In a more direct way than Lull, Ignatius finds himself in a dilemma, namely, to murder the Muslim or to let him go. Ignatius's biographer, Daniello Bartoli, outlines the dilemma in a way similar to what we saw with Lull: outrage and zeal inflamed Ignatius, who already perceived himself as a 'Cavaliere di Christo', which brought him into 'doubt and perplexity' as he heard an 'inner spirit' saying that punishment is public whereas private revenge does not befit a Christian. As a result, "he left the judgment to Chance, or-as he thought—-to Heaven." Eventually, it was God's compassion (pietà) for the inexpert novice, still unable to tell the duties of a Christian from the impulses (spiriti) of a knight, which willed that the horse (cavallo, not mule) take the other way. "Hence Ignatius concluded it to be God's will that [the Moor] lived or at least he should not kill him."51

5o Raimondo Lullo, Libro dell'Ordine della Cavalleria [Libre qui és de l'Ordre de Cavalleria], ed. Giovanni Allegra. ([Carmagnola]: Arktos, 1994), part 5, sect. 14, 206: "A cavall és donat fre, e a les mans del cavaller són donades regnes, a significança que cavaller pe lo fre refrèn sa boca de parlar letges paraules e falses; e refrèn ses mans que no dó tant que haja a quérrer, ni sia tan ardit que de son ardiment git seny. E per les regnes entena que ell se leix menar vers qual part l'ordre de cavalleria lo vulla aempar ni trametre. E con hi serà mester, $[. .$.$] e que sia ardit, e no dubte sos enemics; e con dubtarà de ferir, leix flaquea de$ coratge. E si d'açò lo cavaller fa lo contrari, son cavall, qui és bèstia que no ha raó, segueix mills la regla e l'ofici de cavalleria que lo cavaller."

$5^{1}$ Bartoli, Della vita, lib. 1, p. 26, the episode concludes with the words: “... d'onde Ignatio interpretò, esser voler di Dio, o che colui vivesse, o almeno ch'egli non l'uccidesse." This sentence is missing in the English translation: Daniel Bartoli, History of the Life and 
We know that throughout his years of pilgrimage, Ignatius always wanted to go to Jerusalem. In fact, he planned to go there right after his visit to the Black Madonna of Montserrat. Eventually, after many frustrations and disappointments, while his still unofficial Society never managed to get a passage to the Holy Land, he desisted from his plans only because Christ himself appeared to him at La Storta, saying: "In Rome I will be more favorable to you." ${ }^{52}$ The choice of the mule in our episode has the same message as Christ on the way to Rome: divert your itinerary away from your mission to the Muslims and towards what later would be called the Catholic Reformation!

In terms of ideology and personal mindset, the universal message of Ignatius's narrative may actually lie in the chivalric framework. Pierre Quesnel (1699-1774), an eighteenth-century French biographer, enhanced exactly those motives and called Ignatius a 'Chevalier de la Vierge' in the title of his book, which bears a title plate with the Saint holding vigil in front of the Madonna. ${ }^{53}$ While following closely the autobiography and Bartoli's biography, ${ }^{54}$ he points out that Ignatius compared the mundane and the spiritual versions of knighthood, opting for the latter, though still with 'marvelous things' in his head. ${ }^{55}$ This interpretation agrees with that of Ribadeneira, who surmises that Ignatius at that juncture was still too much of a soldier and held on to fallacious ideals

Institute of St. Ignatius de Loyola ..., trans. Author of "Life in Mexico," vol. 1 (New York: Dunigan, 1855), 42.

Acta, n. 96.

53 [Pierre Quesnel], Histoire de l'admirable Dom Inigo de Guipuscoa, Chevalier de la Vierge, et fondateur de la Monarchie des Inighistes... Par le Sieur Hercule Rasiel de Selva, vol. 1 (La Haye: Charles le Vier, 1736). This book has been reprinted a few times. According to Dr. Hoefer, Nouvelle biographie générale, vol. 41 (Paris: Didot, 1862), col. 323 f., Quesnel is also author of an anonymous critical Histoire Des Religieux De La Compagnie De Jesus... Pour servir de Suplément a l'Histoire Ecclésiastique des XVI, XVII \& XVIII siécles, in four vols. (Soleure: Librairies Associés, 1740), which also narrates Ignatius' life, however in a very different tone. There is more on Quesnel as a journalist in Lynn Hunt, Margaret C. Jacob, and Wijnand Mijnhardt, The Book that Changed Europe. Picart and Bernard's "Religious Ceremonies of the World" (Cambridge, Mass.: Harvard University Press, 2010), 336 n. 22. Thanks to Ugo Baldini for ascertaining in the Jesuit archives that Quesnel was not affiliated with the Jesuits.

54 Quesnel's book presents itself as a chivalric novel, suppressing the name Loyola, but de facto it is a biography.

55 Quesnel, n. XIII, 16: “... après avoir comparé la Chevalerie errante Mondaine avec la Spirituelle, donna la Préférence à celle-ci, parce qu'il y trouva un plus grand Merveilleux.” 
of honor. ${ }^{56}$ Quesnel further explains that Ignatius followed the model of Amadis and other 'Histoires Romanesques,' which requires that new knights hold a 'vigil in armes' before being accepted into the order. ${ }^{57}$ In his view, Ignatius wanted to fulfill this 'essential formality,' and therefore held the vigil described in the autobiography. This is how he became a Knight of the Virgin. ${ }^{58}$ Shortly thereafter, Quesnel continues, the unknown knight would make the hitherto unknown town of Manresa 'extrémement célèbre,' thanks to the Pilgrim's 'penitence.' Although he adopted this observation from Bartoli's account, ${ }^{59}$ he added that in this Ignatius surpassed "Amadis de Gaule... et...Dom Quichotte." ${ }^{60}$ Even though we are aware that in reality it was Cervantes who imitated Ignatius and his role models, this remark does not necessarily abate the piety of the Saint, but rather ridicules-in agreement with the Pilgrim - the exterior orientation that remains ostentatious in its modesty. An English translation of the book has even promoted Ignatius to a 'Spiritual Quixote.' ${ }^{61}$ With this, however, the author and the translator clearly take advantage of the Pilgrim's self-critique, especially the critique of the chivalric ideology and pride that kept besetting him. We should remember that Ignatius dictates his memoir late in his life when he was critical of his chivalric beginnings, and that he is showing how slowly he freed himself from them.

From this perspective, the vigil at Montserrat may acquire an important meaning for our interpretation of the Moor episode. For Ignatius does not immediately hold this vigil; rather, in the order that he tells it, he first ponders the examples of "Amadis of Gaul and books of that sort" and chooses "to abandon his clothes and to clothe himself in the armour of Christ."

$5^{6}$ Ribadeneira, Vita, cap. 3, fol. 8v: "Homo quippe militaris, et fallaci veri honoris imitatione olim delusus..."

57 Similarly, Bartoli, Della vita, 28. On this and other rules concerning the chivalric vigil, see Leturia, Iñigo, 141-144. On such vigils in honor of St. Mary, required from new to be invested knights in the Middle Ages, see Léon Gautier, La chevalerie (Paris: Welter, 1895), 288-291, which included depositing weapons on the altar. Also Lull reports the vigil in arms: Libro dell'Ordine della Cavalleria, part 4, sect. 3, 180-182 and note 4.

$5^{8}$ Quesnel, n. XVI, 25 f. Cf. Acta/Reminiscences, n. 17-18. Cf. Bartoli, Della vita, 28, and Ribadeneira, Vita, cap. 4, p. 9 v.

59 Bartoli, Della vita, cap. 11, p. 29: "E Manresa ... famosa hoggidì, e venerabile per le memorie che conserva ... dell'estreme penitenze, che S. Ignatio vi fece."

6o Quesnel, n. XVIII, 27 .

61 [Pierre Quesnel], The Spiritual Quixote; Or, the Entertaining History of Don Ignatius Loyola, Founder of the Order of the Jesuits.... (London: Bouquet, 1755). The French text (p. 3) says at the beginning that Ignatius made himself "aussi fameux dans la Chevalerie errante Spirituelle, que Dom Quichotte, son illustre Compatriote, l'a été dans la Mondaine.” 
Following this, he delivers a general confession to his confessor, and with the same confessor he arranges to take the mule and to hang his sword and dagger in the church "at the altar of Our Lady." Ignatius emphasizes that this was an important decision. ${ }^{62}$ Then, he enacts his plans and abdicates all attributes of violence by dressing as a mendicant and pilgrim, and by holding the vigil "with his staff in his hands," i.e., as a pilgrim. So, the French biographer was correct: Ignatius does change the worldly knighthood into a spiritual one, and by giving his weapons as $e x$ voto $^{63}$ to St. Mary, he begins transforming courtship into Marian devotion. ${ }^{64}$ While conducting the ritual of initiation into knighthood, Ignatius sheds the mundane knighthood and becomes a vassal of Christ. From now on persecuting Muslims is no longer an objective, the founder of the Jesuits ultimately exhorts his readers.

Compared with Lull's experience and message, Ignatius's is simpler; however, it also simplifies and reduces the problem. For in his narrative, the drive to the Holy Land and to convert Muslims appears to be a mere impulse, the naïve calling of a descendant of the knightly class. He describes it as the same impulse to imitate the saints: 65 mere daydreams of a youth who has not yet realized that the role of a hero and the role of a companion of Jesus are conflicting and incompatible. God and the mule must determine the true calling. ${ }^{66}$

It is understandable now that the Moor episode foretells the La Storta vision, which was held to be the key to the Jesuits' mission away from the Muslims and towards reform within the Christian world (which was almost torn apart by

62 Ignatius, Reminiscences, n. 17, 20; Acta, 47 uses the term “determinación”. [See p. 171, with note 46]

63 James Broderick, Saint Ignatius Loyola. The Pilgrim Years (New York: Farrar, Straus and Cudhay, 1956), 85. Bartoli, Della vita, lib. 1, cap. 10, 28 has Ignatius leave dagger and sword only after the night and assigns the act no specific importance.

64 I am indebted to Robert Miola for prompting me to investigate this motif.

65 Acta, nn. 7, 9, 14, 24.

66 Andrew Olesh, Jr., suggests comparing both narratives with the experience of St. Francis of Assisi. Indeed, the Fioretti tell an episode that is comparable, namely, when Francis converts the Sultan. See Guido Davico Bonino, ed., I fioretti di San Francesco (Milan: Einaudi, 1964), chapter 24, 66-68. The components of predication and God's intervention are there; however, it is not the saint who refrains from violence but the Muslim; and it is (most likely) not a firsthand dictated narrative. John Victor Tolan, Saint Francis and the Sultan: The Curious History of a Christian-Muslim Encounter (Oxford: Oxford University Press, 2009) is a study of the episode in the medieval context and its reception through the centuries. 
heretics of all brands). Therefore, compared with Lull's narrative, the CounterReformation narrative teaches:

- Mission in the post-medieval world requires rational discourse.

- The other knows at least as much about the would-be missionary as the missionary does about the other. Hence, a civil discourse is necessary but possibly without result.

- The sword of the sermon has turned into the sword of persuasion, and where that fails, even violence is pointless.

- If the missionary is ignorant of the dialectics of violence and non-violence, he should take recourse to external intervention.

- Consequently, regarding mission to non-believers: do not even try! Reform your own religious behavior instead.

These are the conclusions we may draw from Ignatius's narrative. When compared with the conclusions drawn from Lull's narrative, they mark a clear development following the realization of the paradoxical or even dialectical nature of converting others, which eventually led towards the internal reform of Christianity as it took place during the sixteenth century. 
PART 3

Muslim Responses to Christianity 



\title{
The Messiah 'Isa, Son of Mary: Jesus in the Islamic Tradition
}

\author{
Asma Afsaruddin
}

\begin{abstract}
Although Abraham is considered the common progenitor of the world's three monotheistic religions, Jesus may be considered the central figure in defining their relationship to one another. Jews reject him as the promised Messiah, Christians embrace him as their Redeemer, and Muslims both accept him as a messianic prophet and reject him as a savior. The status of Jesus in these three religious traditions is therefore critical in demarcating their outer boundaries in relation to one another. Until not too long ago, it was assumed that these were essentially antagonistic positions, incapable of amelioration. As Jews, Christians, and Muslims increasingly co-habit today, however, many of these positions have softened and each is willing to listen to the other's perspective as a way of illuminating one's own. In this essay, I will discuss Muslim perceptions of Jesus as shaped by foundational religious texts within Islam and the larger, internally diverse Islamic tradition, in the context of Christian-Muslim conversations on the importance of Jesus in each religion. Muslim and Christian valorizations of the servant of God, whom both call the Messiah (Christ), will thus be seen as both distinctive and as sharing many common features, which will consequently allow for Jesus to emerge not as a divisive figure but as one who creates opportunities for greater appreciation of the other's tradition.
\end{abstract}

\section{Jesus in the Qur'an}

The name Jesus, 'Isa in Arabic, is mentioned twenty-five times in the Qur'an. Al-Masih 'Isa, or Jesus the Messiah (Christ), is a Qur'anic prophet in a long line of prophets, sent by God to an erring humanity over time. This point is underscored through the frequent mention of Jesus' name in connection with other biblical prophets in the Quran. Jesus is therefore part of a long line of prophets, who were righteous men sent by God through time to various communities in order to preach an unchanging divine message of monotheism and to bring an erring humanity back to the primordial religion of islam, understood in a non-confessional sense of surrender to the one universal God. Jesus is also 
among a select group of prophets who were given a specific revelation that constituted the proofs for the truth of their mission. Thus Qur'an 2:87 states: "And truly We gave to Moses the Books and We caused a train of messengers to follow after him, and We gave to Jesus, son of Mary, clear proofs and We supported him with the holy spirit." The holy spirit (al-ruh al-qudus) is glossed in the exegetical literature as a reference to the angel Gabriel, ${ }^{1}$ who was also the bearer of heavenly revelation to the Prophet Muhammad.

The revelation vouchsafed to Jesus is specifically termed the Injil or the Gospel, and, like the Qur'an, it does not represent a supersession or abrogation of previous revelations, but rather, is considered a confirmation. Thus, Qur'an 5:46 says:

We caused Jesus, son of Mary, to follow in their footsteps, confirming what was before him, and We bestowed on him the Gospel in which there is guidance and light, confirming that which was before it in the Torah-a guidance and a reminder to those who are careful.

In fact, the Quran instructs the Prophet Muhammad to declare to his listeners that Muslims must believe in the prior revelations vouchsafed to God's messengers, who are equally righteous and blameless. The equality of God's messengers is a recurrent theme in the Qur'an and in the Islamic tradition, even though a number of medieval Muslim theologians went on to articulate a doctrine of supersessionism ${ }^{2}$ vis-à-vis the Jewish and Christian scriptures, ${ }^{3}$ in explicit defiance of verses such as Qur'an 3:84:

1 See, for example, al-Tabari, Jami' al-bayan fi ta'wil al-qur'an (Beirut: Dar al-kutub al-ilmiyya, 1997), 1:448-449. Al-Tabari notes, however, a minority viewpoint that regarded the holy spirit as a reference to the Gospel that strengthened Jesus.

2 Supersessionism (naskh in Arabic) is a doctrine that developed among a considerable number of medieval Muslim theologians, according to which Islam abrogates the validity of Judaism and Christianity before it. For a critique of this position as contrary to the Qur'an, see my article "The Hermeneutics of Inter-Faith Relations: Retrieving Moderation and Pluralism as Universal Principles in Qur’anic Exegeses," Journal of Religious Ethics 37 (2009): $331-54$.

3 See, for example, Ibn Taymiyya, al-Tafsir al-kabir, ed. 'Abd al-Rahman 'Umayra (Beirut: Dar al-kutub al-ilmiyya, n.d.), 4:136-138, where he discounts the possibility that Jews and Christians may still hope for salvation on the basis of their religions, despite the occurrence of Qur'anic verses 2:62 and 3:69, which state the opposite, for he maintains that these religions have been corrupted since their formative period. In addition to supersession, some 
Say: We believe in God and what is revealed to us and what was revealed to Abraham and Ishmael and Isaac and Jacob and the tribes, and what was entrusted to Moses and Jesus and the prophets from their Lord. We make no distinction between any of them, and to Him we have surrendered (muslimun). ${ }^{4}$

The Qur'an further asserts that all the prophets submitted to a similar covenant with God, and each proclaimed the same essential message. Accordingly, the sectarian divisiveness among humans is a result of their faulty understanding over time of the divine eternal message, which was faithfully conveyed by all of God's apostles. Thus, Qur'an 33:7-8 states:

And when We exacted a covenant from the Prophets, and from you (O Muhammad) and from Noah and Abraham and Moses and Jesus, son of Mary. We took from them a solemn covenant; that He may ask the loyal of their loyalty. And He has prepared a painful doom for the unfaithful.

And again, Qur’an 42:13 states:

He has ordained for you that religion which He commended to Noah, and that which We inspire in you (referring to Muhammad), and that which We commended to Abraham and Moses and Jesus, saying, "Establish the religion and do not be divided in it."

Jesus, like all the prophets preceding him, is thus innocent of the theological wrangling that ensued among his followers and the followers of other prophets, and furthermore, the Qur'an affirms that there is no fundamental disjunction between the Judeo-Christian revelation and the Islamic one. ${ }^{5}$ Jesus was granted the proofs and the necessary wisdom to invite all to follow the straight path, which represents God's primordial religion, as stated in Qur'an 43:63-64:

(by no means all) pre-modern theologians have focused on the alleged corruption (tahrif) of Jewish and Christian scriptures to posit the superiority of Islam.

4 For a discussion of inclusivist and exclusivist understandings of this verse and of the term Islam itself, see Abdulaziz Sachedina, The Islamic Roots of Democratic Pluralism (Oxford: Oxford University Press, 2001), 38-40.

5 The Qur'an frequently refers to itself as confirming (musaddiq) the previous revelations vouchsafed to the People of the Book (cf., for example, $2: 41 ; 2: 91 ; 3: 3 ; 3: 50 ; 5: 48 ; 35: 31$, etc.). 
When Jesus came with the proofs, he said, "I have come to you with wisdom, so as to make clear to you that regarding which you used to differ. So worship God and obey me. Indeed, God is my Lord and your Lord, so serve Him; this is the straight path."

These Qur'anic passages are reminiscent of Matthew 11:19, in which Jesus is described as being filled with wisdom, as well as of John 20:17 and Matthew 7:13f., in which he exhorts people to follow the narrow and straight way, which is the path of God. ${ }^{6}$

Jesus, as a Quranic exemplar, is presented as a prophet, a teacher, and a humble servant of God. He is also above all a human being whose biographical details constitute some of the most moving passages in the Qur'an. Through the emotive accounts of Jesus' birth and his brave and almost implausible defense of his chaste and helpless mother, the Qur'an establishes God's deep solicitude for the infant Jesus and his single mother. There are several references to the birth of Jesus in the Qur'an; the lengthiest and one of the most evocative accounts of the dramatic circumstances of Jesus' birth are recorded in the nineteenth chapter, which is wholly devoted to Mary and titled Surat Maryam, in verses 16-34. These verses embody powerful language to convey the significance of this seminal event and to elicit a sense of deep compassion in reference to a defenseless young mother and her child. The bond between them is portrayed as stronger than the usual mother-child relationship, for they are described as also being direct agents in the unfolding of God's selfrevelation to humankind.

In verses 16-34, Mary encounters the spirit (Gabriel) who assumes the likeness of a perfect man and identifies himself as a messenger of God. When he informs her that she would give birth to a blameless son, she remonstrates:

How can I have a son when no mortal has touched me, neither have I been unchaste? He said: So your Lord says: It is easy for Me. And (it will be) that We may make of him a revelation for mankind and a mercy from Us, and it is a thing ordained. And she conceived him, and she withdrew with him to a far place. And the pangs of childbirth drove her to the trunk of the palm tree. She said, "Oh, would that I have become nothing, forgotten!" Then (one) cried to her from below her, saying: Grieve not! Your Lord has placed a rivulet beneath you. And shake the trunk of the palm tree toward you. You will cause ripe dates to fall on you. So eat and drink and be consoled. And if you meet any mortal, say: I have vowed a fast to

6 Cf. Geoffrey Parrinder, Jesus in the Qur'an (Oxford: Oneworld, 1995), 95-96. 
the Compassionate, and may not speak this day to any mortal. Then she brought him to her own folk, carrying him. They said, "O Mary! You have come with an amazing thing. Oh sister of Aaron! Your father was not a wicked man nor was your mother a harlot." Then she pointed to him. They said: "How can we talk to one who is in the cradle, a young boy?" He spoke, "See! I am the servant of God. He has given me the Book and has appointed me a Prophet, and has made me blessed wherever I may be, and has enjoined on me prayer and almsgiving so long as I remain alive. And (has made me) dutiful toward her who bore me, and has not made arrogant, and unblessed. Peace on me the day I was born, and the day I die and the day I shall be raised alive!" Such was Jesus, son of Mary: (this is) a statement of the Truth concerning which they doubt.

Thus, Mary's initial doubt about the possibility of the virgin birth is considerably allayed by her personal encounter with the divine and her receptivity to being selected as an instrument of good in the world - against remarkable odds. Above all, poignantly etched in these verses is a loving mother-child relationship, tinged with desperation but also with unwavering servitude to God. The infant Jesus and his virgin mother appear to be pitted against a faithless world, which is all too eager to pass judgment on them. After all, who could possibly be more vulnerable to societal criticism than a barely pubescent girl and her child, born out of conventional wedlock? Yet God chose to act in history through the medium of these ostensibly contemptible, insignificant individuals, whose obedience to God's calling serves as a paradigm of faith and service for all humanity. And to send this message home, Jesus in the Qur'an is addressed primarily in terms of his relationship to his mother. In a run-of-themill, patriarchal society, the appellation 'Jesus, Son of Mary' must have raised some eyebrows and further underscored their marginal status. One need not be a feminist per se to appreciate how piety in these sacred narratives is rendered in non-gendered terms, and that foundational texts in both Islam and Christianity recognize goodness equally in men and women, as well as their equal agency in transforming the world. This perspective gets elided in the gendered constructions of piety and legal rights that later developed in both traditions, but is fully retrievable from the Qur'an and the Christian Bible. ${ }^{7}$ The tale of Mary and her child destined for greater things is above all a story of how

7 See in general Asma Barlas, "Believing Women" in Islam: Unreading Patriarchal Interpretations of the Qur'an (Austin, Tx: University of Texas, 2002), where she convincingly demonstrates how androcentric interpretations of the Qur'an have progressively masked its fundamental gender egalitarianism. 
a personal relationship with and fealty to God can transcend socially constructed categories and human systems of valuation. ${ }^{8}$

\section{Jesus as the Word of God and the Promised Messiah in Qur'anic Exegesis}

We now proceed to focus on another shorter but significant cluster of verses (Qur'an 3:45-47), referring to the birth of Jesus and to his various attributes. Since some of these attributes appear to be emphasized equally in Islam and Christianity, we will analyze them at greater length and present the views of a number of prominent Muslim exegetes. The verses under discussion state:

Behold the angels said: O Mary! God gives you good tidings of a Word from Him: his name will be Christ Jesus. The son of Mary, held in honor in this world and the hereafter and of (the company of) those nearest to God; He shall speak to the people in the cradle and in maturity. And he shall be one of the righteous. She said; O my Lord! How shall I have a son when no man has touched me? He said: Even so: God creates what He wills: when He has decreed a plan, He only says to it, Be-and it is!

These significant passages in the Qur'an from the third chapter titled Al Imran (the family of 'Imran) are particularly worthy of our attention because they are much cited in the literature comparing the position of Jesus in Islam and Christianity. Furthermore, to Christian ears, they sound similar to the description of the Annunciation that occurs in the Gospel of Luke (1:26-38). It will be a useful exercise for us to review quickly what some of the major Muslim commentators have said concerning several critical concepts pertaining to Jesus in these verses. Among these critical concepts are 'a word' (kalima) and the Messiah (al-masih), which remain contested notions among Muslim exegetes themselves, and which are also of great interest to Christian theologians who have similarly struggled to define these notions in relation to Jesus.

The well-known commentator al-Tabari (d. 923) understands 'a word' as referring to the good tidings imparted by God to Mary concerning 'a son for you whose name is the Messiah, 'Isa son of Mary.' He nevertheless presents an

8 For assessments and appreciations of Mary's exalted role in the Islamic tradition, see, for example, Aliah Schleifer et al., Mary, the Blessed Virgin of Islam (Louisville, KY: Fons Vitae, 1997); Mary F. Thurlkill, Chosen among Women: Mary and Fatima in Medieval Christianity and Shi'ate Islam (Notre Dame: University of Notre Dame Press, 2007). 
alternative interpretation, which understands 'a word' to be a reference to the divine command in the verse, "Be!"9 $\mathrm{Al}$-Tabari also points out that the famous Companion Ibn 'Abbas was of the opinion that the word (al-kalima) was a reference to Jesus himself, "who is the word from God."10 From these, Al-Tabari prefers the first explanation that he lists for kalima; that is, a reference to the good tidings that the angels brought to Mary about Jesus' prophethood and the annunciation that God would grant her a son (walad) without a husband, whose name would be the Messiah or the Christ." ${ }^{11}$ The full designation 'The Messiah, son of Mary,' continues al-Tabari, underscores the fact that Jesus was indeed the son of his mother, thus negating the claims of Trinitarian Christians as well as the accusations of impurity hurled at Mary by the Jews. ${ }^{12}$

As for the term 'The Messiah', it is interpreted by al-Tabari as meaning that God Himself had wiped the sins off Jesus, on account of which 'the Messiah' may be equated with 'the Truthful One' (al-Siddiq). Others, however, have claimed that the name Messiah referred to someone who was touched by blessings (musiha bi'l-baraka). ${ }^{13}$

The noble status (wajihan) promised to Jesus is a reference to the elevated status that he would enjoy both in this world and the next, continues al-Tabari. Furthermore, the verse promises that he would be brought close to God on the Day of Judgment. His ability to speak to people from his cradle allowed him to defend his mother from the slanderous lies circulated about her, and it was a confirmation of his prophecy. Later, his speech to people as a mature man (kahlan) allowed him to convey the message of God as revealed to him, and to enjoin what is good and forbid what is wrong. According to one source, however, the reference to Jesus' speech as a mature man refers to his second coming when he will kill the anti-Christ. ${ }^{14}$ The final part of the verse, according to al-Tabari, is an affirmation that God can create ex nihilo; Jesus' birth by a virgin mother is an attestation to this divine attribute. ${ }^{15}$

A prominent exegete of the Seljuq period, Fakhr al-Din al-Razi (d. 1210), also has much to say on these two verses and hence a synopsis of his extensive commentary is offered here. He comments that just as the just ruler can be described as 'the shadow of God on earth' and 'the light of God,' implying that

$\begin{array}{ll}9 & \text { Al-Tabari, Jamic al-bayan, 3:268. } \\ 10 & \text { Ibid. } \\ 11 & \text { Ibid. } \\ 12 & \text { Ibid., 3:269. } \\ 13 & \text { Ibid., 3:269-70. } \\ 14 & \text { Ibid., 3:271-72. } \\ 15 & \text { Ibid., 3:272. }\end{array}$


he is a medium (sabab) for the appearance of the shadow of justice and the light of charity (al-ihsan), Jesus is similarly a medium for the appearance of the word of God, which serves to elucidate the Truth and dispel doubts and falsehoods. It is in this sense that Jesus is named 'the Word of God the Almighty'16

To someone who might remonstrate that every human being must spring from a father, al-Razi is quick to refute this position by pointing to Qur'an 3:59, which states: "Indeed the likeness of Jesus in the presence of God is the likeness of Adam." Since Adam did not require a father to be born, Jesus does not require a father, either. Furthermore, it is pointed out that the world of animals is replete with examples of auto-genesis, as well as the reproduction of creatures unrelated to the parent. ${ }^{17}$ Interestingly, al-Razi seems to be appealing here to observable facts (as he understands them) and the world of nature to establish the miraculous nature of the birth of Jesus.

The phrase 'a Word from Him' contains the Arabic preposition min, which usually connotes a partitive sense ( $t a b^{\prime}$ id $)$; here, however, al-Razi explains that the preposition cannot be understood in a partitive sense, since that would imply a composite divine nature capable of being divided into constituent parts that could in turn be assembled into a whole. Composite bodies belong to created beings, "and God is far removed from that!" he asserts. Thus, the phrase 'a Word from Him' conduces to the meaning that the Word of God (Be!) was the origin of Jesus' coming into being and has nothing to do with the notion of incarnation. ${ }^{18}$

What, then, is the significance of the Arabic title al-Masih (the Messiah)? Al-Razi lists several possibilities that testify to the fecundity of the root $m s h$ in Arabic, which essentially means 'to rub, to anoint.' According to one source, Jesus earned the title because he would barely touch someone afflicted with disease and that person would be healed. Another source maintained that it was because Jesus had been anointed with a special blessed oil reserved for prophets, which serves as a sign for the angels to recognize all those who were born to be prophets. Yet another source commented that it was so because Gabriel is said to have brushed Jesus with his wings at the time of his birth so that he would be protected from being touched by Satan. ${ }^{19}$

As for the full appellation - the Messiah 'Isa, son of Mary—it indicates to al-Razi that 'Isa is his given name while 'the Messiah' is an honorific title, and

\footnotetext{
16 Al-Razi, al-Tafsir al-Kabir (Beirut: Dar Ihya al-Turath al-'Arabi, 1999), 3:221.

17 Ibid., 3:221-22.

18 Ibid., 3:222-23. Here, of course, al-Razi is specifically taking issue with the Christian position on the Logos and with incarnationists in general (al-Hayluliyya).

19 Ibid., 3:222-23.
} 
'son of Mary' is descriptive in the sense that it describes a fact. According to another source, the ascription specifically to Mary underscores that Jesus was born without a father, unlike other prophets, and that contributed to "an increase in his merit and enhancement of stature." 20

Jesus' noble stature in this world and the next is stressed in the Arabic word wajihan used in the verse in relation to him, continues al-Razi. As he explains, this adjective describes someone who is "possessed of [a high] station, honor, and esteem." It can also describe someone who is very generous. The same word was used to describe the status of Moses in Qur'an 33:69, both in this world on account of his function as a prophet, as well as in the next on account of his high rank in the presence of God. With regard to Jesus, it additionally referred to his ability to raise the dead, cure the leper, and heal the sick in this world, while in the next it referred to his status as an intercessor for his community, whose intercession will be accepted, as will that of the other great prophets. Furthermore, the epithet suggests that Jesus was innocent of the slurs cast at him by his enemies in this world, and was assured of an elevated status in the next because of "the plenitude of his merits" (kathrat thawabihi). ${ }^{21}$

From both al-Tabari's and al-Razi's exposition, it is therefore clear that neither the expression 'a Word from Him' nor 'the Messiah' corresponds to Christian notions of the Logos and Savior, respectively. These Qur'anic epithets applied to Jesus are to be understood in the context of his humanity and his role as a prophet selected by God in a long line of prophets, who had varying degrees of skills and aptitudes commensurate with the needs of their time and the people to whom they were sent. Many of the miracles attributed to Jesus in the Gospels are affirmed by the Qur'an and sometimes even elaborated upon by the exegetes, since they are credible manifestations of an all-powerful God who can directly intervene in history when He wants. Furthermore, Al-Razi's caveat that none of these Quranic attributes should be understood as having anything to do with Christian notions of incarnation or immanence is understandable within the Islamic conception of prophethood and its purpose in this world. Despite the similarity in the use of these terms in both traditions, the underlying assumptions about the meaning(s) of Jesus' mission on earth are strikingly different, particularly in the deployment of these epithets. However, the Quran's affirmation of a high status for Jesus in this world and the next would ring true for Christians, and his role as an intercessor in the hereafter on their behalf would sound welcomingly familiar.

20 Ibid., 3:223.

21 Ibid. 


\section{Other Qur'anic Attributes of Jesus}

Jesus' miracles (ayat) are well attested in the Qur'an. In addition to his ability to speak from the cradle, as already mentioned, he healed the leper and the blind man, raised the dead to life (Qur'an 5:110), and breathed life into birds of clay (Qur'an 3:49; 5:110) — deeds that no other prophet has carried out. These exceptional accomplishments attributed to Jesus are balanced in the Qur'an with unequivocal expressions of his servanthood to God and his human status as a messenger of God. Thus, Qur'an 4:172 states: “The Messiah will never scorn to be a servant of God, nor will the favored angels. Whoever scorns His service and is proud, all such will He assemble before Him."22 And again, in Qur'an 5:75 we find the assertion that: "The Messiah, son of Mary, was no other than a messenger, messengers the like of whom had passed away before him. And his mother was a virtuous woman. And they both used to eat (earthly) food."

Jesus is also considered the precursor prophet in the Qur'an, who announces the coming of Muhammad as the Messenger of God after him. In Qur'an 61:6, it is stated:

And when Jesus, son of Mary, said, "O Children of Israel! Lo! I am the messenger of God to you confirming that which was [revealed] before me in the Torah, and bringing good tidings of a messenger who will come after me, whose name is the Praised One (Ahmad).

Ahmad is a variant of the name Muhammad, and is regarded in Muslim apologetic literature as being the equivalent of the Comforter or the Paraclete mentioned in John 16:7, who will allegedly come after Jesus. The Greek word Paraclete is rendered as Periclytos, however, which yields the meaning of 'The Praised One,' which is the meaning of both Ahmad and Muhammad. ${ }^{23}$

From all the Qur'anic references to Jesus, it is perhaps the verses regarding his last days on earth that have sparked the most interest among Christian

22 Kenneth Cragg discerns a similarity between Qur'an 4:172 and the Christological hymn in Philippians, which refers to Jesus taking the form of a servant. Cragg states: "Both Scriptures affirm his being gladly 'servant' to God. That is their unity. The Qur'an however denies his 'Sonship' on the very grounds in which the Christian sees it to consist, namely a loving obedience to God." See his Jesus and the Muslim (London: George Allen \& Unwin, 1985), 30.

23 See a discussion of this in Parrinder, Jesus in the Qur'an, 96-100. 
students of Islam; this topic will now be briefly discussed. The locus classicus for the traditional Muslim understanding of Jesus' last days one earth is Qur'an 4:157-58, which states:

And because of their saying, "Behold, we have slain the Christ Jesus, the son of Mary, the messenger of God-but they slew him not nor crucified but it appeared so to them; indeed, those who disagree concerning it are in doubt thereof; they have no knowledge of it save pursuit of a conjecture; they slew him not for certain but God took him unto Himself. And God is Almighty, All-Wise.

The Qur'anic denial of the killing of Jesus affirms a basic theological premise in Islam, namely, that God does not let evil triumph over goodness (cf. Qur'an $5: 56 ; 9: 32 ; 58: 22 ; 61: 8)$. The wrongdoers may hatch relentless intrigues and plots against Him (Q 3:54; 5:110; cf. Q 8:30; 13:42) and His prophets, but their machinations will never prevail in the end. ${ }^{24}$ Jesus' ascension to heaven is a resounding affirmation of God's omnipotence and the vanquishing of His enemies. William A. Bijlefeld has called the Qur'anic denial of Jesus' death on the cross a "corrective denial," 25 which challenges the Jewish claim that they had crucified him and thereby proved that he was not the Messiah, as well as the Christian belief in the role of the cross in the redemptive atonement, although the cross is not specifically mentioned in these Quranic verses. The prevalent position among the overwhelming majority of Muslim exegetes and scholars is that Jesus was raised by God to His presence while still alive, and thus miraculously delivered from the harm intended by his enemies. ${ }^{26}$

24 Cf. Qur'an 3:54, which states: "And they (the disbelievers) plotted, and God plotted, and God is the best of the plotters."

25 Willem A. Bijlefeld, "Other Faith Images of Jesus: Some Muslim Contributions to Christological Discussions," in Christological Perspectives: Essays in Honor of Harvey K. McArthur, ed. Robert F. Berkey and Sarah A. Edwards (New York: Pilgrim Press, 1982), 204.

26 The rich and diverse exegetical tradition that grew up concerning these verses is discussed comprehensively by Todd Lawson in his The Crucifixion and the Qur'an: A Study in the History of Muslim Thought (Oxford: Oneworld Publications, 2009). For a detailed comparison between Muslim and Christian traditions on this topic, see A. H. Mathias Zahniser, The Mission and Death of Jesus in Islam and Christianity (Maryknoll, NY: Orbis Books, 2008); cf. Parrinder, Jesus in the Qur'an, 121. 


\section{Summary of the Points of Convergence and Divergence between Muslims and Christians Concerning Jesus}

To conclude this section on the Qur'anic depiction of Jesus and his prophetic mission, it is useful to summarize the main points concerning both the fundamental agreement and disagreement that exist between Islam and Christianity. As far as the points of convergence are concerned, both Islam and Christianity:

1) show profound respect for Jesus and affirm that while he lived in the world, he was pure and free of sin, and directly guided by God;

2) believe that Mary, Jesus' mother, was chaste, pure, and obedient to God;

3) assert that Mary was a virgin who conceived Jesus miraculously;

4) affirm that Jesus performed a number of miracles, including healing the sick and raising the dead.

Islam and Christianity, however, differ in the following ways:

1) While Christianity declares Jesus to be both human and divine, Islam rejects the notion of Jesus' divinity. As a result, Christians worship Jesus, while Muslims revere Jesus and accept him as an inspired prophet, based on the Qur'anic accounts of his life and acts;

2) Christians regard Jesus as the son of God, a concept that is not accepted by Muslims, who instead affirm that God does not procreate and have offspring.

3) Christianity asserts that Jesus was crucified. Contrastingly, Islam maintains that it only appeared as if Jesus was crucified, and that God instead raised him up to Himself.

4) Christianity maintains that Jesus died in order to redeem the original sin of humankind. For Muslims, however, Jesus does not serve as a redeemer since the concept of original sin is lacking in Islam. Instead, human beings individually earn their redemption through their belief in God and His revealed scriptures, as well as through their commission of righteous deeds. ${ }^{27}$

These points of convergence and divergence between Muslim and Christian beliefs regarding the life and mission of Jesus Christ have made for lively

27 Adapted from the list developed by Alan Godlas, available at http://islam.uga.edu/ jesusdif.html, last accessed on February 10, 2013. 
debates and conversations throughout the centuries, and continue strong in our own time. ${ }^{28}$

\section{Jesus in the Hadith Literature and Muslim Tradition}

In the standard hadith compilations-mainly the Six Books ${ }^{29}$ revered by Sunni Muslims-Jesus is primarily connected with the end of time. This is unique to the hadith literature, for the Qur'an makes no explicit reference to such an eschatological role for Jesus. Two Qur'anic verses—4:159 and 43:61—are understood to allude to Jesus' second coming by the majority of exegetes, ${ }^{30}$ but this (at best) inchoate idea is fully developed only in the extra-Qur'anic literature. Thus, in one well-known hadith (a statement attributed to the Prophet Muhammad), the Companion Abu Hurayra relates:

The Messenger of God, peace and blessings be upon him, said, "By Him in whose hands my soul is, the son of Mary will soon descend among you as a just judge. He will break crosses, kill swine and abolish the poll-tax, and wealth will pour forth to such an extent that one will accept it and one prostration will be better than the world and what it contains."31

There are also hadiths that contain descriptions of the manner in which Jesus will fulfill his eschatological role of overcoming the anti-Christ, called al-Dajjal ('the Imposter') in Arabic, or more fully al-Masih al-Dajjal ('the false Messiah'). This figure is not mentioned in the Qur'an, but is prominent in the eschatological sections of hadith compilations. Here, Jesus' role is to come back during these end-times when the Dajjal makes his appearance, and eventually to slay him. One well-known hadith occurring in an authoritative collection describes in some detail the appearance of the Dajjal, claiming he will be a young man with curly hair and a defective eye, and who will emerge from between

28 Cragg's remark on the 'Christian potential of the Qur'an' is also worthy of note in this context; see his "Islamic Theology: Limits and Bridges," in The Gospel and Islam: A 1978 Compendium, ed. Don M. McCurry (Monrovia, CA: MARC, 1979), 31.

29 The Six Books are: the Sahih of al-Bukhari (d. 870); the Sahih of Muslim b. Hajjaj (d. 875); the Sunan of Ibn Maja (d. 886); the Sunan of Abu Da’ud (d. 888); the Sunan of al-Tirmidhi (d. 892); and the Sunan of al-Nasa'i (d. 915).

30 See Neal Robinson's discussion of these two verses in his Christ in Islam and Christianity (Albany, NY: State University of New York Press, 1991), 78-105.

31 English translation given by Muhammad Ata ur-Rahim, Jesus: Prophet of Islam (Norfold, England: Diwan Press, 1977). 
Damascus and Iraq and will be able to travel fast on earth. When the Prophet is asked how fast the Dajjal will be on earth, he replies:

Like rain backed by wind. He comes to a nation and they believe in him and accept (his message). He commands the sky to rain and it rains, and the earth to grow grass, and it grows. He provides them with plenty of wealth. He comes to another nation and they reject his message. He turns away from them and they become poor with nothing in their hands. He passes a remnant of an ancient city and tells her "take out your treasures." Its treasures follow him like bees, then he calls a man full of youth and strikes him with his sword, cutting him in two. Then he calls him and he (the youth) comes laughing with shining face (as if al-Dajjal was unable to kill him), at that moment God sends Jesus the son of Mary. He descends on the top of the white minaret at the east of Damascus, putting his hands on the wings of two angels. (He is so beautiful that) When he bows his head, water drops when he lifts it and shines like pearls. Any nonbeliever who finds his breath will be killed; his breath reaches as far as his sight. He pursues al-Dajjal and finds him at the gate of Lydda, then he kills him. Then a nation who was saved in the trial of the Anti-Christ comes to Jesus. He touches them and tells them about their levels in paradise. At that time God inspires Jesus that he has sent some people (Gog and Magog) that no one can defeat. And God says: "Take my servants to the mountain of Tour."32

While some Muslim theologians accept the content of the above hadith and others similar to it as literal references to specific events at the end of time, others detect in them broad allegorical references to a final showdown between good and evil, with a prominent role accorded to Jesus, who will end the frightful reign of the Dajjal and inaugurate the messianic era. He will fill the earth with justice and peace, and put an end to hatred and poverty. Jesus will then marry and beget children, and all will believe in him during this era of peace. ${ }^{33}$

Jesus also plays a prominent role in other, non-standard collections of delightful reports and anecdotes concerning biblical prophets who impart profound wisdom to a Muslim audience and instruct them in the proper ways of

32 Muslim, Fitan, \#110; translation given by Zeki Saritoprak, "The Legend of al-Dajjal (Antichrist): The Personification of Evil in the Islamic Tradition," Muslim World 93 (2003): 293-94.

33 Mahmoud M. Ayoub, "Towards an Islamic Christology, II: The Death of Jesus, Reality or Delusion," Muslim World 70 (1980): 120-21. 
the world. They form part of a literary genre known as the 'Tales of the Prophets' (Qisas al-anbiya'), which have proven to be very popular. A well-known historian of Islam, Tarif Khalidi, has collected many of these reports concerning Jesus and published them in a monograph entitled The Muslim Jesus. In this 'incarnation' of Jesus (to use the term in a non-theological sense), he is, as Khalidi describes it, at times "the ascetic, the prophet of the heart, the gentle teacher of manners, the mystic, the lord of nature, the healer of spiritual ills." ${ }^{34}$ One homiletic tradition states:

It was said that Jesus, son of Mary, peace be upon him, met a man and said to him, 'What are you doing?' He replied, 'I am devoting myself to God.' He said, 'Who is providing you with what you need?' He said, 'My brother.' Jesus then said, 'He is more devoted to God than you.'35

The report contains a gentle rebuke that faith and solitary worship without good deeds is less meritorious and less desirable than good deeds accompanied by faith. Hence, acts of charity and social interactions with one's fellow beings are a necessary complement to private devotion to God.

In another wise saying, Jesus counsels:

Time revolves around three days: a yesterday which has passed away and during which you have been admonished, a today which supplies your needs, and a tomorrow in which you do not know what is in store for you. All matters revolve around three things: a thing whose rightness has become apparent to you and which you must follow, a thing whose evil has become apparent to you and which you must shun, and a thing which appears uncertain to you and which you must defer to God. ${ }^{36}$

Jesus thus exhorts a Muslim audience to adopt a commonsensical approach to time - to learn from past mistakes, maximize today's potential, and not worry unduly about what tomorrow may bring. Furthermore, one must couple selfreliance with a fundamental reliance upon God and His beneficence. Jesus also

34 Quoted in the article "The Fifth Gospel: Tarif Khalidi and Jesus in the "Muslim Gospel," interview and commentary by Salim Tamari, available at www.jerusalemquarterly.org/ images/Articlespdf/15_gospel.pdf, last accessed on February 12, 2013.

Tarif Khalidi, The Muslim Jesus: Sayings and Stories in Islamic Literature (Cambridge, Mass.: Harvard University Press, 2003), 102.

36 Ibid., 77 . 
affirms a basic ethical tenet within Islam in this didactic report, namely, the upholding of what is good and right while avoiding what is evil and wrong.

Jesus is also invoked as a worldly-wise figure that warns against those who would yoke religious authority to worldly power, and admonishes the ostensibly pious who do not practice what they preach. Such a sad state of affairs is a harbinger of the end-times, for which he predicts:

At the end of time, there will be religious scholars who preach abstinence but do not themselves abstain, who encourage yearning for the afterlife but do not themselves yearn, who forbid visits to rulers but do not themselves desist, who draw near to the rich and distance themselves from the poor, who recoil from the lowly and fawn upon the mighty. They are the tyrants and the enemies of the Merciful God. ${ }^{37}$

The great affection and veneration that Muslims are encouraged to harbor towards Jesus and his mother is perhaps best encapsulated in a story about the fall of Mecca in $630 \mathrm{CE}$, preserved in the biography of the Prophet Muhammad by Ibn Hisham. According to Ibn Hisham, when Muhammad entered the Kaba, the shrine that housed the Meccan pantheon, he ordered that all its idols and paintings be cleansed or destroyed. One of the paintings held there was of the Virgin and the Christ-child. The Prophet is said to have approached this icon, covered it with his cloak, and did not allow it to be washed away. ${ }^{38}$ Whether this anecdote is true or apocryphal is irrelevant for our purposes. What matters is that the report is quite archaic and is extracted from some of the earliest historical narratives about the founding of the Muslim community. Its preservation and dissemination in the foundational literature of the Muslim community illustrates a fundamental reverence on the part of Muslims for the figure of Jesus, who along with his virgin mother epitomizes what it means to be a willing and humble servant of God.

\section{Jesus in Edifying and Sufi Literature}

Jesus is much beloved in devotional literature of all sorts, and is especially popular in Sufi literature. The celebrated magnum opus of Abu Hamid al-Ghazali

Ibid., 103-104. As Khalidi comments (ibid., 104), the behavior of these ulama' "echoes the behavior of the Pharisees rebuked by Jesus in Matthew, and merits a more direct censure of Muslim scholars who sell their integrity in order to gain favor with rulers, a reversal of the true vocation of scholars." 
(d. 1111), Ihya 'ulum al-din, contains several reports concerning Jesus that emphasize his proclivity for asceticism and otherworldly spirituality. One such report relates: "Jesus lay down one day with his head upon a stone. Satan, passing by, said: 'O Jesus, you are fond of this world.' So Jesus took the stone and cast it from under his head, saying: "This be yours, together with this world. "39

The Sufi's constant efforts to purify himself or herself by forsaking the vain things of this world and its vain company, all of which distract from the remembrance of God, are exemplified by Jesus and his abstemious ways. To illustrate this, we can once again extract an edifying anecdote from al-Ghazali's Ihya, which relates what Jesus once said to his disciples:

"O disciples, seek the love of God by your hatred of sinners; seek to be near Him by [doing] that which distances you from them; and seek His favor by being angry with them." He [Malik $]^{40}$ said, "I do not know which [commandment] he began with." They said, "O Spirit of God, whose company then shall we keep?" He replied, "Keep the company of him whose sight reminds you of God, whose speech increases your knowledge, whose deeds make the afterlife desirable."41

Jesus, in al-Ghazali's depiction, is a very human Jesus, who accepts his lot in life as divinely ordained, experiences frustration and despair, and makes no attempt to use physical force to overcome any adverse situation. His gentleness and patient resignation are invoked by al-Ghazali as a model to be emulated by mystical practitioners, and he encourages them to pray the way Jesus did:

O God I have arisen from my sleep and am not able to ward off that which I hate and am not able to possess the benefit of that which I desire and the matter rests in hands other than mine. And I have pledged myself to my work and there is no man so poor as I am. O God, let not my enemies rejoice over me and let not my friends deal ill with me, and let not my afflictions come to me in matter of my religion. And do not allow the world to occupy my care, and do not allow the unmerciful to overcome me, O Thou Eternal! ${ }^{42}$

\footnotetext{
39 Samuel Zwemer, "Jesus Christ in the Ihya of al-Ghazali," The Muslim World 7.2 (1917): $144-45$.

40 This is Malik b. Mighwal (d. 776), who was an early traditionist from Kufa and transmitted many sayings attributed to Jesus.

41 Khalidi, Muslim Jesus, 57.

42 Ibid., 150.
} 
Jesus' meekness and ascetic piety are celebrated by other Sufis as well, as he constitutes a model and guide for their way of life, centered on a renunciation of the wealth and luxury of this world. This is the path to true happiness, says Jalal al-Din Rumi (d. 1273), as confirmed by Jesus' ministry, which he describes as follows:

From all sides the people ever thronged Many blind and lame, halt and afflicted At the door of the house of 'Isa at dawn, That with his breath he might heal their ailments.

As soon as he had finished his orisons?....

He spoke to them saying, "O stricken ones,

The desires of you all have been granted by God,

Arise, walk without pain or affliction,

Acknowledge the mercy and beneficence of God. ${ }^{43}$

In mystical literature, Jesus is often called the 'man of sorrows,' though he is also considered a prophet who through exemplary piety and abstinence has achieved nearness to God-a trait that Sufis strive to emulate. ${ }^{44}$ Thus, the wellknown Persian Sufi poet Mahmud Shabistari (d. 1340) describes the pious mystic as one who "obtains release from his own knowledge, and, like the prophet Jesus, he becomes near to God. He gives up his existence utterly to be plundered and in the steps of the most pure he ascends." ${ }^{m 5}$

Ibn 'Arabi (d. 1240), a celebrated mystical philosopher from the thirteenth century, went on to call Jesus 'the Seal of the Friends of God' on account of having achieved the highest knowledge of God. In Ibn 'Arabi's understanding, a wali (literally 'friend,' usually translated into English as 'saint') is one who on account of his knowledge of God realizes his essential unity with God the Creator (Arabic, wahdat al-wujud; i.e., monism). Furthermore, Ibn 'Arabi distinguishes between general prophecy and particular prophecy. General prophecy, which is identified with 'friendship with God' (wilaya), refers to "those personal laws which are entrusted to people 'created for Himself, chosen for His service and selected from among His worshipers for His presence." "46 That

\footnotetext{
43 Translation given by Kenneth Cragg, Jesus and the Muslim: An Exploration (Oxford: Oneworld, 1999), 6o-61.

44 Ibid., 59-63.

45 Ibid., 60.

46 Andreas D'Souza, "Jesus in Ibn 'Arabi's Fusus al-hikam," Islamo-Christiana 8 (1982): 196.
} 
is, the Friends of God (awliya) receive certain personal laws directly from God. These personal laws deal with the recipients' relationships to God, and hence are manifested primarily in their worship of God and cannot be propagated. Particular prophecy, on the other hand, which includes both the prophets and the apostles, is related to the institution of laws. Being temporal, it has come to an end with Muhammad, who is 'the Seal of the Prophets.' Therefore, no new law will be proclaimed to abrogate, contradict, or complement the law of Muhammad. ${ }^{47}$ Whereas prophethood and apostleship are temporal, wilaya is eternal and continues into the future. Being eternal, wilaya (or friendship with God) is regarded by Ibn 'Arabi as being of a higher degree than prophethood and apostleship. Thus, Jesus will return to the earth during the end-times as the seal of the Friends of God, for there will be no more awliya after him. ${ }^{48}$

\section{Jesus among the Shi'a}

The Shi'a, like Sunni Muslims, hold Jesus in great esteem. He is regarded as one of the five most important prophets, called the 'Prophets of Power,' the other four being Noah, Abraham, Moses, and Muhammad. However, for the Shi'a, Jesus is not only a prophet but also an imam - that is to say, a spiritual leader and a vicegerent of God. As an imam he is endowed with esoteric knowledge and belongs to both the exoteric and esoteric cycles of prophethood. In Shici Islam, the imams are greater and more exalted than all the prophets who came prior to the Prophet Muhammad. ${ }^{49}$ The Shica also tend to see certain aspects of Jesus' person and life reflected in their imams. For example, the Shi'a believe in the priority of the imams as God's primordial Word and Spirit, and that it is through the imams, and for their sake, that everything was created. According to Mahmoud Ayoub, the conception of Jesus as the divine Logos and God's spirit has probably contributed to the Shici view that the imams are God's primordial Word and Spirit. ${ }^{50}$

Both the first imam 'Ali and the second imam, his son al-Husayn, are considered to be the embodiment of the betrayed and suffering martyr. Al-Husayn, on account of the events at Karbala, in particular is regarded as mirroring Jesus

\footnotetext{
47 Ibid., 197-98.

48 Ibid., 199-200.

49 Ibid., 62.

50 Mahmoud Ayoub, "Towards an Islamic Christology: An Image of Jesus in Early Shici Muslim Literature," The Muslim World 46 (1976): 167-168.
} 
in his sufferings. Several reports recorded by Shi'a scholars relate how Jesus presciently lamented the future martyrdom of al-Husayn. According to one of these accounts, a lion once blocked Jesus and his disciples when they arrived at Karbala during their peregrinations. When Jesus asked the lion the reason for his behavior, the lion said: "Here will be killed the grandson of the Prophet Muhammad and I will not let you pass until you curse his murderers." Jesus then inquired about the would-be murderers of al-Husayn, to which the lion responded: "He is the accursed of the inhabitants of the heavens and earth, of the beasts of the fields, and the fish of the sea, he is Yazid."51 Lifting up his hands to the heavens, Jesus then cursed the murderer and his companions four times, and the disciples responded with "Amen." The lion then allowed them to proceed. ${ }^{52}$

Although the Shi'a do not claim that al-Husayn was born of a virgin mother, some among them believe that both al-Husayn and Jesus had a miraculous nativity because each was in the womb for only six months. Like Jesus, al-Husayn had also praised God from his mother's womb, and was similarly capable of raising the dead. Some among the ghulat - that is, Shici extremists outside the mainstream tradition-have gone even as far as to say that al-Husayn, like Jesus, did not die and was miraculously raised to heaven instead. ${ }^{53}$

Because of the striking similarities in their lives and earthly roles, the Shici in general regard al-Husayn to be Jesus' brother. Although al-Husayn was not a prophet, his position as an imam conferred on him a status similar to prophethood in terms of cosmic importance. This is signaled in a report emanating from the fifth Shi'i imam, Muhammad al-Baqir, who stated:

On the night that 'Ali was killed, under every stone that was turned there was found congealed blood. The same thing happened also when Aaron (Harun), brother of Moses, and Joshua, son of Nun, were killed; when Jesus was lifted up to heaven, and when Simon Peter (Sham'un al-Safa) and Husayn, son of 'Ali, were killed. ${ }^{54}$

$5^{1} \quad$ Yazid was the second Umayyad caliph during whose reign al-Husayn and his family were killed on the battlefield at Karbala' in Iraq.

52 Mahmoud Ayoub, Redemptive Suffering in Islam: A Study of the Devotional Aspects of Ashura in Twelver Shi'asm (Berlin: De Gruyter, 1978), 35.

53 Ibid., 36 .

54 Ibid., 34-35. 


\section{Modern Views}

Moving on to the modern period, we find that there is a tendency among a number of modern Muslim authors to emphasize the universality of Jesus' prophethood, in order to find common ground between Islam and Christianity on the basis of shared universal ethics that can bridge theological differences. Furthermore, the universality of Jesus' mission can be justified on the basis of the Qur'an; verse 2:191, after all, describes Jesus as an aya or 'a sign' for all peoples, in parallel with the New Testament (John 4:1-26 and Luke 7:1-10), which describes Jesus' ministry as embracing not only the Jews but also the Samaritans, Romans, Phoenicians, and Greeks.

In his book 'Abqariyyat al-Masih ("The Genius of the Messiah"), the Egyptian author 'Abbas al-'Aqqad (d. 1964) portrays Jesus as a prophet-teacher whose message has universal significance. Although Jesus and his disciples began their mission in Galilee within the traditional Jewish ethno-religious framework, they eventually embraced universal humanity as they progressively defied the Jewish establishment. Al-'Aqqad emphasizes that the universality of Jesus' mission inheres in his ethical message, which he fought to promote by launching a spiritual warfare against his own baser instincts and vigorously counseling others to do likewise. As he explains it:

It is quite clear that we must recognize that the Messiah is of the same material as his companions, the great prophets, for whom spiritual warfare knew no truce. This continual struggle against themselves condemns them to anguish and brings them to question at the deepest level their own faithfulness or unfaithfulness to the path which God has chosen for them. It is undoubtedly this warfare which is expressed in the gospel narrative of the temptation. Christ is victorious in this trial, like the other prophets, in agony, struggle and anguished acceptance. ${ }^{55}$

Al-Aqqad emphasizes the social justice component of Jesus' universal message, as well as the transformational nature of this project. He was solicitous towards women and the poor, and was charitable and forgiving toward all, including his enemies, notes al-'Aqqad. Jesus the Christ succeeded primarily in a spiritual vein in conveying his message, continues our author, in comparison

55 Translation given by Penelope Johnstone, "Christ Seen by Contemporary Muslim Writers," Encounter 87 (1982): 5 . 
to the Prophet Muhammad, who was successful both spiritually and socially in conveying and establishing his message for all of humanity. ${ }^{56}$

Another Muslim author, Khalid Muhammad Khalid, emphasizes the complementarity of the missions of Muhammad and Jesus in his book Ma'an 'ala al-tariq: Muhammad wa l-masih ("On the Road Together: Muhammad and the Messiah"). He cites the hadith that describes the brotherhood of the prophets as a proof-text, and refers to Jesus' role as the precursor prophet and the eschatological prophet. Thus, Jesus is a necessary complement to Muhammad's prophethood since he had foretold the latter's coming as 'the Seal of the Prophets,' while Muhammad is a necessary complement to Jesus' prophethood since he had announced the latter's second coming as the eschatological prophet. Khalid comments that this complementarity should be an invitation for Christians and Muslims to work together in order to improve human society and further the common good. ${ }^{57}$

\section{Conclusion}

Khalid's message is often repeated in our own times - the way forward for Christians and Muslims is to emphasize the universality of the ethics they share and their common reverence for Jesus, rather than focusing on the theological differences that separate them. In 2009, Robert Shedinger, a Lutheran academic, published a book provocatively titled Was Jesus a Muslim?,58 in which the author explores the question of whether Jesus can be considered a Muslim. His ultimate answer is yes-for if Jesus is regarded primarily as someone who was supremely concerned with social justice, then he was as much of a Muslim as Muhammad or, one could add, as any other prophet was. Perhaps this is shocking to some Christian ears, but to Muslims it reassuringly affirms the commonality of the messages imparted by righteous men chosen by God to be His devoted servants. As we recall, 'Abbas al-'Aqqad had also similarly emphasized the ethical message of Christianity, which was the basis of its common ground with Islam. Even though Muslims reject for the most part the christological doctrines concerning the nature of Christ, they nevertheless embrace him as an essential part of Islam, whose existence and ministry made possible the culminating mission of the Prophet Muhammad.

\footnotetext{
56 Al-Aqqad, Abqariyyat al-Masih (Cairo: Dar Nahdat Misr, 1973), passim.

57 Cragg, Jesus and the Muslim, $5^{2} \mathrm{ff}$.

58 Robert Shedinger, Was Jesus a Muslim? Questioning Categories in the Study of Religion (Minneapolis, MN: Fortress Press, 2009).
} 
It would be fitting to end this essay by quoting Tarif Khalidi, who simply and elegantly explains why Jesus remains the common link between Muslims and Christians, and why their common love for him will continue to bring them together, despite critical doctrinal differences. Khalidi memorably writes:

So: I think it can safely be shown that Islamic culture presents us with what in quantity and quality are the richest images of Jesus in any nonChristian culture. No other world religion known to me has devoted so much loving attention to both the Jesus of history and to the Christ of eternity. This tradition is one that we need to highlight in these dangerous, narrow-minded days. The moral of the story seems quite clear: that one religion will often act as the hinterland of another, will lean upon another to complement its own witness. There can be no more salient example of this interdependence than the case of Islam and Jesus Christ. And for the Christian in particular, a love of Jesus may also mean, I think, an interest in how and why he was loved and cherished by another religion. ${ }^{59}$

Given the increasing dialogic encounters between contemporary Christians and Muslims, Khalidi's comments are particularly appropriate and point the way ahead for more productive conversations regarding the meanings of the life and mission of the Messiah 'Isa, which resonate strongly in both traditions.

59 Remarks posted at www.bbc.co.uk/religion/religions/islam, last accessed on 2/15/2013. 


\title{
Revisiting the Charge of Tahrīf: The Question of Supersessionism in Early Islam and the Qur'an
}

\author{
Sandra Toenies Keating
}

In recent times, a great deal of interest in bringing about peace and harmonious relations between Muslims and Christians has been generated, both within the walls of the academy and beyond. This renewed interest has caused many aspects of the interactions between the two communities to be reassessed, resulting in an explosion of new research, editions, and translations of significant texts, and fresh insights into ancient questions. On the whole, this movement has been positive and productive, engaging people from around the globe in an endeavor that could have far-reaching consequences.

There has also been the propensity, however, to downplay real points of disagreement in an effort to reach the goal of peace. Nowhere is this more apparent than in the tendency to discount the importance of the theological convictions of the communities being studied. In many cases, researchers with little interest in or sensitivity to theological questions discount such evidence as 'bias' in an effort to find 'what really happened.' For some, the answer to tensions between adherents of the two religions is simply to conclude that debates about 'abstract and theoretical' questions of truth are useless in the academy, since no definitive conclusions can be reached by human inquiry. Unfortunately, in many cases this has led to historical and linguistic studies that, although helpful, neglect the cultural values and overall intentions of the author(s) of the texts or of the community within which these texts were preserved and transmitted. Thus, conclusions are drawn concerning texts and accounts of events without taking seriously the theological impact they have had on the communities that preserved them. This approach, moreover, imposes contemporary (often academic) interests and assumptions on authors and communities far removed from our own concerns. One can identify such non-theological interpretations in almost every area of Islamic studies, which has generally been relegated to history, political science, or religious studies.

Nevertheless, these non-theological interpretations obscure the religious convictions of the founder of Islam and his followers. It seems that almost from the very beginning, Muhammad understood himself as a religious reformer, drawing his listeners back to the primordial worship of the One God. It is very clear from the earliest sources that Muhammad and his followers believed that he was a prophet like the prophets of the Jews and Christians, 
and he expected that his message would be recognized and accepted by those communities. When they did not welcome him as one of their own, however, an explanation was necessary. It is here that the notion of tahrif comes into play. In its developed form, tahrif is the Islamic teaching that the scriptures of other monotheists and/or their interpretations have been corrupted, and thus obscure the message that had been previously sent by God. The implication of tahrîf is that the Qur'ān comes both to confirm (cf. Sura 4:46-7) and to correct errors in the teachings of the Jews and Christians, making Islam not simply another monotheistic religion, but rather, the final and most pure revelation by which all others are measured. In recent years, however, some scholars have argued that this was not Muhammad's intent, and that supersessionist ideas should be attributed instead to later sources.

A particular movement among researchers into the origins of the Qurān and the early Islamic community has thus postulated a rather late appearance of sectarian Islam. This movement has taken off in two general directions. One group, characterized by the provocative book of Christoph Luxenberg, ${ }^{1}$ has sought to demonstrate that the religion now known as Islam has its origins in an initial confusion over earlier Syro-Aramaic texts, perhaps as the result of a misguided attempt to evangelize the Arabs. A related view is that the body of literature traditionally identified as the Qurān came to be associated with the Arab chieftain Muhammad at a later date, even though he was only peripherally responsible for it. These scholars have also tended to emphasize socioeconomic rather than theological reasons for the rise of Islam. ${ }^{2}$

A second group of scholars has taken a more irenic approach, suggesting that the earliest followers of Muhammad were an inter-confessional group including Jews, Christians, and other monotheists who, according to Fred Donner, ${ }^{3}$ called themselves 'Believers' and whose primary criterion for membership was belief in the one God. They argue that it was only later, perhaps more than a century after Muhammad's death, that the sayings and traditions associated with him were collected together into the present forms of the

1 Christoph Luxenberg, The Syro-Aramaic Reading of the Koran: A contribution to the decoding of the language of the Koran (Berlin: Verlag Hans Schiler, 2007).

2 In this group I would include many of the contributions of Patricia Crone and Michael Cook and their followers. Theories about the relationships among the appearance of early Islam, Muhammad, and the Qurān are in flux and beyond the scope of this paper. For a good summary of several of them, see Stephen J. Shoemaker, The Death of a Prophet: The End of Muhammad's Life and the Beginnings of Islam (Philadelphia, Pennsylvania: University of Pennsylvania Press, 2012), especially the Introduction and chapters 1-2.

3 Fred M. Donner, Muhammad and the Believers: At the origins of Islam (Cambridge, Massachusetts: The Belknap Press of Harvard University Press, 2010), see especially chapter 1. 
Qurān, Sīra (biography), and hadìth. Consequently, these texts reflect not the original teachings of Muhammad, but rather, a later ideology desiring to establish the community of Believers separate from Christians and Jews. Thus, the ideology shifted from an early emphasis on the commonality of Jewish, Christian, and general monotheistic belief in the One God, the impending Hour of Judgment, and the importance of Syro-Palestine, to the creation of a separate identity for 'Those Who Submit' (muslimūn) and the sacred geography of Arabia. ${ }^{4}$

Recently, a proponent of this approach, Stephen J. Shoemaker, has published an intriguing book entitled The Death of a Prophet, ${ }^{5}$ which builds upon the work of previous scholars such as Donner, Cook, Crone, and Wansbrough. He proposes that the most significant characteristic of the earliest community of Believers who had gathered around Muhammad was the shared belief in an imminent eschatology - the expectation that the final Hour would arrive within the lifetime of Muhammad. Remnants of this teaching can be found both in non-Muslim accounts of the appearance of Islam, as well as in the reshaped orthodox accounts of Muhammad's death. Shoemaker argues, rather convincingly I believe, that when Muhammad died before the coming of the final Hour, his followers needed to rethink and reinterpret his message, ultimately leaving the eschatological aspects of his teaching aside. As a consequence, the contents of the Qurān and Sīra were systematized at a date quite removed from Muhammad's life. They reflect an attempt to collect the material and put it into an order that would make sense out of both the truth of Muhammad's message (and its confirmation through the success of the Islamic conquests) and how events had actually turned out — the Hour had not arrived as expected. I find many aspects of Shoemaker's arguments thought-provoking, and his collection and analysis of early non-Muslim accounts of the rise of Islam is quite helpful. However, he is not able to effectively account for the gap between his hypothetical version of the early community and demonstrable characteristics of Islam less than a century later. ${ }^{6}$

As compelling as the vision of an irenic prophet and his multi-cultural followers is, I am inclined to question many of the conclusions reached by these

4 See various contributions of Patricia Crone and Michael A. Cook, Hagarism: The Making of the Islamic World (Cambridge: Cambridge University Press, 1977); Patricia Crone, Slaves on Horses: The Evolution of the Islamic Polity (Cambridge: Cambridge University Press, 1980); Suliman Bashear, Arabs and Others in Early Islam, vol. SLAEI 8 (Princeton: Darwin Press, 1997); and John E. Wansbrough, The Sectarian Milieu: Content and Composition of Islamic Salvation History, vol. London Oriental Series 34 (Oxford: Oxford University Press, 1978).

5 Shoemaker, Death of a Prophet.

6 See my review of Shoemaker's book in Hugoye 16/1 (2013): 160-165. 
recent books. Two issues in particular do not seem to be accounted for in this approach to the origins of Islam. First, while he is to be commended for taking seriously the evidence found in non-Muslim sources for evaluating the Muslim tradition, Shoemaker has paid little attention to a significant source, namely, those texts that recount early interactions between Muslims and Christians that reveal a deeper awareness of theological differences between the two communities. For example, Christian writers in Greek, such as Anastasius of Sinai (d. ca. 700), ${ }^{7}$ and in Syriac, such as Jacob of Edessa (d. 708), ${ }^{8}$ are quite aware of the teachings of Muslims that are critical of Christian beliefs concerning the Trinity and Incarnation. These, along with several other references to the beliefs and practices of the young Muslim community, imply that at least the broad outlines of Islam's distinctive characteristics were already in place by the end of the seventh century. This is a little-studied area of inquiry, primarily because until recently it was assumed that non-Muslim sources were of little value for understanding what was taken to be a firmly established account of Muslim origins.

Second, although the Qurān was collected and preserved in a manner that appears random, it nonetheless reflects a more developed theological system than these theories acknowledge. One finds in the Qurān a distinctive understanding of revelation, sin, covenant, prophethood, ethics, etc. A peculiar aspect of the Qur'ann, though, is that it does not reflect any attempt to organize the material thematically or historically. In fact, it seems difficult to explain why, if the text was collected and edited in the eighth or even early ninth century as a few scholars have proposed, more effort had not been given to making it more consistent and orderly, as one finds in the Sīra and hadith. ${ }^{9}$ Furthermore,

7 For example, he complains that the Arabs accuse Christians of worshipping two gods (cf. Qurān 16:51, as well as 5:116, in which Jesus denies that he taught his followers to worship himself and his mother as gods). Viae dux I.1, 9 (PG 89, 41A), cited in Robert G. Hoyland, Seeing Islam as Others Saw It: A survey and evaluation of Christian, Jewish and Zoroastrian writings on early Islam, Studies in Late Antiquity and Early Islam 13 (Princeton, New Jersey: The Darwin Press, Inc., 1997), 107.

8 Sidney H. Griffith, The Church in the Shadow of the Mosque: Christians and Muslims in the World of Islam (Princeton: Princeton University Press, 2008), 30-33.

9 Shoemaker sees the possibility of parallels in the formation of the New Testament canon and that of the Qurān. One great difference, though, is that the New Testament writers were apparently interested in offering their readers a consistent 'story line' within a particular context (e.g., Matthew is concerned with demonstrating the ways in which Jesus fulfilled Jewish prophecy, Luke is writing for Gentile converts). The Qurān, however, does not exhibit any attempt at order or even desire to give a clear answer to particular questions. If the collectors and redactors had a particular agenda, they were certainly not as effective in communicating it as they might have been! 
if the Qur'ān had been written down as late as some are suggesting, the clear misunderstanding of Christians and Christianity found in it becomes even more puzzling. How could the Qur'an have been so mistaken about the role of Jesus, Mary, and the Trinity in Christian doctrine during a period in which there was close contact between Muslims and Christians? ${ }^{10}$ If one assumes a very early date for the verses concerning Christian teaching, these errors could be explained as the result of misinformation; later dating, however, renders them inexplicable. ${ }^{11}$

Therefore, the question ultimately is: how aware was the initial community of Muhammad's followers (indeed, Muhammad himself) of the differences between his message and what was regarded as 'orthodox' Christianity and Judaism in the Arabian Peninsula? It has long been recognized that the canonical Qur'ān contains apparently contradictory verses, which can best be understood when assigned to particular contexts. Although the extent to which it is possible to associate these verses with a specific period in Muhammad's life (e.g., 'Meccan' or 'Medinan') has recently been called into question, it nonetheless remains clear that the early community felt compelled to include all of these verses, meaning that it attributed some sort of authority to them. The verses can be grouped together according to the extent that they reflect a positive/optimistic or a negative/skeptical view of the teachings and behavior of Christians and Jews. Given the fact that those verses that display a negative view also imply the possibility of having some authority and power over these other communities, one can surmise that they belong to a later period, after Muhammad's ascendancy had begun. Furthermore, these verses appear to exhibit a development, as Muhammad and his followers began to reflect on what they believed God was doing at that point in history. Inconsistencies and even apparently outright contradictions are likely explained as reflecting historical development in Muhammad's thought and experience. The accounts of Christians, Jews, and both their scriptures found in the Qurān reflect such a development, and the earliest evidence of the teaching of tahrîf can give us some insight into the issue.

10 Jane Dammen McAuliffe, Qur'ānic Christians:An Analysis of Classical and Modern Exegesis (Cambridge: Cambridge University Press, 1991).

11 An explanation of the odd references to Christian teachings that include Mary in the Trinity (4:171, 5:116) and the seemingly garbled account of the Last Supper (5:112-7) has eluded scholars and commentators. Over the centuries some have suggested that these refer to aberrant Christian groups or to Muhammad's confusion about these doctrines. A major contribution toward answering this problem has been made by Sidney H. Griffith in his recent book, The Bible in Arabic: the Scriptures of the 'People of the Book' in the Language of Islam (Princeton: Princeton University Press, 2013). 
As I will argue below, the formulation of the doctrine of tahrif gives us a strong indication that Islam was from its inception supersessionist - the view that the new revelations sent by God would replace the corrupted scriptures possessed by other communities. Muhammad seems to have gradually come to understand himself as a reformer, first bringing the Arabian polytheists to monotheism, and then drawing Jews, Christians, and other monotheists back to their original scriptures. Thus, although, he did not assume that God had commanded identical customs or languages for all people, it seemed clear to him that God would not command contradictory things of different people. Muhammad's teachings thus reflect a unification of monotheistic groups, but with a particular vision of what society should look like. In this sense, the Qurān could be seen as a 'corrective,' as well as a confirmation of what had come before.

\section{Revelation and Supersessionism}

One of the intriguing questions surrounding the origins of the Qur'an is the context that prompted its appearance. Was it a reaction against closed Christian and Jewish communities who made no attempt to draw Arabian polytheists toward monotheism? Or was it the desire of Muhammad and his followers to have a religion in the monotheistic tradition that expressed particularly Arabian norms and values, which was then transformed into a religion claiming roots in the family of Abraham? In my opinion, a glaring problem with current theories of the origins of Islam is the lack of a compelling account of why the early followers of Muhammad did not simply join any of the monotheistic communities available in the Arabian Peninsula at the time, of which there was apparently a wide variety. There are many reasons to expect that the inclination of the tribes toward monotheism would bring them within the folds of Judaism, Christianity, or Zoroastrianism, as had already happened in northern Arabia. Certainly by the end of the sixth century there seems to have been a self-conscious movement among historically polytheistic Arabians toward monotheistic beliefs and nominally Jewish practices. The Qurān, however, does give us a few hints at the answer to this question, suggesting that the revelation to Muhammad is an 'Arabic reading' (qur'änan 'arabiyyan) of 'the clear Book' (al-kitäbi-l-mubin), which brings what had previously been revealed in other languages to the Arabic-speaking tribes (Sura 12:1-3). One might identify in this clue some parallels to the early mission to the Gentiles among the followers of Jesus - the belief that it was imperative that God make the revelation known to these peoples in their native tongue. 
Our available sources do not provide a coherent report of the earliest stages of the interplay between the messages Muhammad received and his interpretation of their meaning and implications. Nonetheless, even if one rejects the traditional Islamic account of the origins of the Qurān and Islam, it does seem to be the case that Muhammad and his followers saw themselves as submitting to an ancient set of monotheistic beliefs and rituals that was different from those of their polytheistic ancestors; the evidence also suggests that the change was prompted by private revelations that had come to Muhammad. These monotheistic beliefs included submission to a single, all-powerful and all-knowing, merciful Creator God, a particular moral perspective that demanded a certain relationship with that God, and apparently an imminent eschatology that expected cosmic judgment. All of these have strong counterparts in nearly every form of Judaism and Christianity. Thus, there is no reason to believe that the original community of 'believers' did not see themselves as participating in a larger monotheistic community, accepting what had been revealed as Truth many times before, while at the same time being concerned that what they held was not exactly what their Jewish and Christian neighbors professed.

A growing awareness of discrepancies between Muslim beliefs and those of other monotheists is evident in the Qurān, although not in a systematic way. Rather, in numerous Suras, statements are made in defense of the primacy of the Qur'ann whenever Christians and Jews make claims that contradict a revelation to Muhammad. These references imply that quite soon after the appearance of Muhammad, differences between the messages he delivered and the teachings of the Jews and Christians became apparent. Many theories have been advanced to explain the various references in the Qurann to this problem, ranging from denial that the Qurān rejects orthodox Jewish and Christian teaching, to the claim that Muhammad's intention was to eliminate all other religious practice. It may well be the case that early on Muhammad was quite convinced of the continuity between his message and that of Jews and Christians, but their refusal to recognize him on theological grounds eventually led to a breach. Thus, (and I believe this is the most likely scenario) he began to emphasize errors, first in their interpretation of their scriptures, and then even in the editions of the scriptures themselves.

The critiques of Jewish and Christian scriptures and their interpretations in the Qur'ān are bolstered by an insistence that Muhammad is a prophet in a long line of prophets who brought the same message to their followers. Seen as a whole, however, the Qur'ann presents a theology of revelation that is profoundly different from that of mainstream Judaism and Christianity, in that a fixed text is identified as the fundamental means of divine communication. Whereas God is understood as revealed in the divine relationships of the 
Covenant (seen in God's actions and commands) for the Jews and in the Incarnation for Christians, the Qurān emphasizes instead the clarity and constancy of God's commands. Theologically, one can say that the Jewish and Christian view of 'salvation history' (a Christian term) is that God's plan for His relationship with humanity unfolds over time, a process that is both ongoing and mysterious. The Qur'ān, on the other hand, is insistent on God's unchanging relationship with Creation, a relationship that was made known even in the first revelation to Adam (Sura 2:30-5).

Nevertheless, there are some difficulties with the Biblical view of salvation history, two of which are relevant here. The first is that it is difficult to determine when a new event or 'revelation' should be interpreted as an authentic expression of God's will in His plan. The second is that it is difficult to explain how God can hold individuals equally accountable at the Divine Judgment. If some people were given different commands or did not know critical requirements, how can God justly judge them? For example, Abraham, whom all Jews, Christians, and Muslims revere, had neither the Mosaic Law nor the sacraments, both of which are understood to be obligations by their respective communities. Over the centuries, Jews and Christians have sought to account for this problem in various ways that cannot delay us here. What this problem does throw into relief, though, is the primary purpose of the Quraan: to explain how the new Arabian monotheists fit into God's ancient plan of salvation. The Qurān proposes that Divine justice requires that God's will for human beings be knowable, known, unchanging, and within human capabilities. Thus, there must be a single clear revelation that has been accessible to all human beings in order for God to judge justly. Because God has been revealed as Merciful and Just, He has indeed made His will known to all people so they cannot say on the Last Day that they did not know. ${ }^{12}$ The Qurān is the most recent (and final) copy of that revelation sent to humanity.

According to the Qurān itself, God sent down the revelation to Muhammad as a 'mercy' (rahm) and a 'reminder' (dhikr) to those who would believe. Muhammad was commanded by the Angel Jibril (Gabriel) to recite what he would be given. The recitation (qur'ān) would come from the divine source, the Preserved Tablet (Sura 85:22). This Preserved Tablet (Lawh al-Mahfüz) is also referred to as the Umm al-Kitāb, the Mother of the Book (3:7), which is preserved and guarded from all corruption (15:9). It is a fixed text, unchanging and reliable, which guarantees God's promise of mercy and justice. Among the many verses illustrating this is Sura 43:2-4: "[By] the Clear Book, We have made it an Arabic recitation [Qurān] so that you may understand, and it is in the

12 Among the many examples, Sura 7 gives an extended account of the final Judgment, emphasizing that no one will be able to hide from God's justice. 
Mother of the Book in our Presence, high, wise."13 Significantly, the Qur'ān is characterized here as being 'in' $(f \grave{\imath})$ the Umm al-Kitāb, but the verse does not imply that it is the totality of the Umm al-Kitāb. The Qur'ann is, rather, the final revelation sent down to humanity as a guide on the 'straight path,' as well as the confirmation and 'correction' of all previous authentic revelations. The very use of the word qur'an to describe the revelation implies that it is the reading of a preexistent text, a text that has been revealed to others and that might be mysteriously read in a multitude of languages.

In line with this notion of revelation, the Qurann acknowledges that the 'Book' has been sent down previously to other chosen prophets, among them Adam, Abraham, Moses, and Jesus. To each of these God has sent a pristine copy of a part of the Umm al-Kitāb, so that every people is guided toward perfect submission to Himself (e.g., Sura 6:84-90;10:47; 16:36-7). God does this out of mercy and justice so that each person can be fully prepared for the Final Hour of Judgment. Significantly, these prophets are upright and trustworthy, unlike many of their followers. The Qurān includes numerous accounts of the prophets themselves reprimanding their followers for misunderstanding or refusing to accept the revelation they have been given. For example, in Sura 2:67-71 (The Heifer), the Israelites badger Moses into requesting of God more and more specifics concerning the red heifer they are to sacrifice, each time implying they cannot comply because they do not understand the command. In Sura 5:116-8, Jesus is described as defending himself on the Day of Judgment against those who worship him and his mother as gods. Thus, the blame for discrepancies in the teachings of the Jews and Christians is laid at the feet of the followers of the prophets, and not the prophets themselves, the revelation, or God.

Seen through this lens, many confusing and apparently contradictory passages in the Qurān make more sense. For example, oft-quoted passages such as "To each of you we have given a law and a clear path; and had Allah willed, $\mathrm{He}$ would have made you one people, but [He wants] to test you concerning what He gave to you" (Sura 5:48) and "to you your religion and to me my religion" (Sura 109:6 $)^{14}$ do not reflect the sort of progressive, pluralistic vision of society as contemporary thinkers wish to imagine. Rather, they are reminders that

13 All translations of the Qurān are my own, unless otherwise noted.

14 This verse is widely misunderstood by non-Muslims because it is usually quoted out of context. When read with the verses immediately preceding it, our point becomes clear: "Say: O you who are unbelievers ( $k \bar{a}$ firūn), I do not worship what you worship and you do not worship what I worship. And I will not worship what you have worshiped, and you will not worship what I worship. To you your religion and to me my religion." 
there is no use disputing with those who do not recognize the authentic revelation - at the Final Judgment, God will vindicate His true servants. On this point, the arguments of Shoemaker are helpful. It seems very likely that the early 'Believers' did not waste time disputing with their fellow monotheists because they expected that the end was near and they would be justified soon. In the meantime, they needed to hold fast to the message God had now sent to them..$^{15}$

Muhammad and his followers were convinced that he was receiving a new iteration of revelations previously given, yet paradoxical verses in the collection of these revelations seem to point to a lack of knowledge about the actual beliefs of those to whom God had sent His angels before. It is only over time that Muhammad began to recognize exactly what was different, and what the implications of those differences were. Simultaneously, to understand why Muhammad and his 'Believers' did not simply become Jews or Christians, one has to assume that he thought he was receiving something new or distinctive, something that needed to be preserved in spite of its differences from the 'Books' of the Jews and Christians - something that should replace what they now possessed. It is in this sense that Islam was from its very origins supersessionist.

\section{Taḥî́f and Supersessionism}

All of this leads to some significant questions about the theological perspective of early Islam. In this short paper, we will address two interrelated issues, which have a sort of 'chicken and egg' relationship. Perhaps the problem can be best expressed in the following questions: in what way did Muhammad and his followers understand the differences between what he was preaching and the teachings of other monotheists, and how did this come to be expressed in the Qurann? From an Islamic viewpoint, the true revelation was given first to Muhammad, followed by communal reflection on its differences from Jewish and Christian teachings. Historical-critical methods, however, have indicated that the multitude of verses commenting on the scripture, teachings, and status of Jews and Christians are likely the result of increased interaction with members of these communities. In any case, the early Muslim community felt it necessary to account for these discrepancies, and traditionally, Muslim answers to these questions have been found in the doctrine of tahriff. At this point we will give some general outlines of the sources for this teaching in the

15 See especially Shoemaker, Death of a Prophet, ch. 3. 
Qurān, and try to ascertain whether those who have questioned its importance for Muhammad and his early followers are correct.

The term tahrif comes from the second form of the Arabic root harafa, which means to slant or bend, distort, misconstrue, or falsify. The expression, as will be discussed below, refers both to a particular type of distortion of the revelation, as well as to distortion of revelation and its general interpretation. A broad definition of tahriff is the Islamic notion that Jewish and Christian scriptural texts, as well as subsequent interpretations of them, have been manipulated or misunderstood. Consequently, the Qur'ān itself claims that God sent this revelation down through Muhammad as a reminder of the true revelation. A particularly relevant passage concerning the relationship between previous scriptures and the Qurān states:

And We have revealed to you (Muhammad) the Book in truth, confirming what was already possessed of the Book and guarding ${ }^{16}$ over it. So judge between them according to what Allah has revealed, and do not follow their vain desires, diverging from what came to you of the Truth. To each of you we have given a law and a clear path; and had Allah willed, He would have made you one people, but [He wants] to test you concerning what He gave to you. Strive, then, towards good deeds. To Allah is the final goal of all of you, He will instruct you concerning that on which you differed. And judge between them with what Allah has revealed, and do not follow their vain desires. Beware of them lest they lure you away from part of what God has revealed to you. And if they turn away, know that Allah only wishes to punish them for some of their transgressions, and that many people are indeed rebellious! (Sura 5:48-49)

Passages such as these have traditionally been understood to teach that the Qurān is both a confirmation that God has revealed scripture to human beings (so they can be judged justly for their actions), and that the 'clear path' has been obscured by 'grave sinners,' necessitating a further corrective revelation. The Qurān thus affirms the authenticity of these previous scriptures while also correcting diverging accretions associated with them, among which are Christian teachings on the Trinity, Incarnation, and celibacy, as well as the suppression of revelations predicting the prophethood of Muhammad. As noted above, the understanding of revelation presented in the Qurann rejects any notion that God's will unfolds or that recent revelation 'builds on' what is more ancient, because such a belief calls God's justice into question. 
In short, there is no principle of 'development of doctrine' as one finds in Christianity. Rather, tahrîf explains how the same revelation received by a myriad of prophets can exhibit such differences in the hands of the followers of those prophets. From the Qurānic perspective, the revelation to Muhammad remains the norm by which other revelations are judged for their authenticity, superseding and correcting all contradictions and deviations from it.

A complication for understanding the role of tahriff in early Islam is that the Qurān hints at the tension among the monotheistic communities in a multitude of ways, preventing any single clear-cut definition. Only a few studies have been made on the term in the Qurān, most significantly in an important (but not often cited) article by Caspar and Gaudeul. ${ }^{17}$ They note that several specific terms are used in the Qur'ān in relation to the divergence between what was taught by Jews and Christians and what Muhammad had 'received.' Each of these terms appears to refer to a different type of 'alteration' of the original revelation, ranging from simple misinterpretation or forgetfulness to intentional changing of meanings and even rewriting of the text. The terms can be categorized according to two recognizable groups: tahrîf al-ma'āni (alteration/corruption of the meaning of authentic scriptures) and tahriff al-naș (alteration/corruption of the actual text of the scriptures). A further distinction made within tahrîf al-ma'ānī is that of ta'wīl, or interpretation of the meaning. ${ }^{18}$ One finds these categories reflected in later commentators, who generally emphasize either the proclivities of Jews and Christians to misinterpret (intentionally or unintentionally) their scriptures, or who maintain that the extant Jewish and Christian scriptures have been physically altered. ${ }^{19}$

17 Jean-Marie Gaudeul and Robert Caspar, "Textes de la tradition musulmane concernant le tahrīf (falsification) des écritures," Islamocrhistiana 6 (1980): 61-104.

18 Gaudeul and Caspar, "Textes de la tradition musulmane," 61.

19 Several significant studies have been done on the later use of tahrif by Muslims, for example I. di Matteo, "Il 'tahrîif' od alterazione della Bibbia secondo i musulmani," Bessarione 38 (1922): 64-111, 223-60; Gaudeul and Caspar, "Textes de la tradition musulmane"; Hava Lazarus-Yafeh, Intertwined Worlds: Medieval Islam and Bible Criticism (Princeton: Princeton University Press, 1992); I. Resnick, "The Falsification of Scripture and medieval Christan and Jewish Polemics," Medieval Encounters (1996): 344-80; Hava Lazarus-Yafeh, "Tahrîf," in Encyclopedia of Islam, Vol. 10 (2000), 111a; and Martin Accad, "Corruption and/or Misinterpretation of the Bible: The Story of the Islamic Usage of Tahrif," Theological Review-Beirut (2003): 67-96; as well as the recent comments by Gabriel Said Reynolds, "On the Qur’anic Accusation of Scriptural Falsification (tahrīf) and Christian Anti-Jewish Polemic," Journal of the American Oriental Society 130/2 (April-June, 2010): 189-202. 
Under the two main headings introduced above, six different verbs or their derivatives are employed in the Quraan when speaking of the corruption of the scriptures through human interference: tahrîf, tabdīl, kitmān, labs, layy, and nisya $\bar{a} .{ }^{20}$ Verses that point to the attempt to distort the meaning of the scriptures often use the word kitmān, which connotes 'hiding or concealing,' (Sura $2: 42,140,146,159,174 ; 3: 71,187)$, and is sometimes found in conjunction with labs, 'disguising' (2:42; 3:71). Sura 2:42, for example, exhorts the Jews of Medina: "And do not disguise (talbisü) the truth with falsehood, nor conceal (taktumū) the truth, for you know it." A third term, lawā, meaning 'to twist,' suggests that pronunciation of certain words during the recitation of the scriptures was corrupted so that the listener either did not understand it properly, or would misunderstand (Sura 3:78; 4:46). For example, Sura 3:78 says of the People of the Book:

And there is among them a group who twist (yalwūna) the Book with their tongues, so you would think it is from the Book, but it is not from the Book; and they say 'it is from Allah,' but it is not from Allah, and they tell a lie against Allah and they know it.

In Sura 4:46, furthermore, this 'twisting' is used to explain tahrîf:

Some of the Jews alter the words (yuharrifunna) out of their places, and they say: 'We have heard and we disobey', and 'Hear without Harkening,' and ' $r \bar{a}$ ' $i n \bar{a},{ }^{21}$ twisting (layyan) their tongues and slandering religion.

Here the verse suggests that by changing the words, the revelation is made to say the opposite of what God intended. The following verses continue with the explanation without clearly stating whether this twisting and alteration is intended, until it is clarified in verse 50 . In this verse, which brings the section to a conclusion, the underlying intentionality is finally discussed: "See how they invent the lie against Allah, and that alone is a clear sin!"

The Qurān also implies that false interpretation of the meaning of the scriptures stems from a disregard for important passages, or from simply forgetting certain revelations. The term nisyān, 'forgetting, overlooking,' is used both in reference to Jews (Sura 7:53, 165; $5: 13$ ) and Christians (5:14; 7:53). Sura 5:13-4 relates how God punished the Jews and Christians because they broke

20 Gaudeul and Caspar, "Textes de la tradition musulmane," 62-3.

21 This is a term of abuse. 
their Covenant by cursing them and making both of them "forget a large part of what was given to them."

A more serious form of tahrîf is tabdīl, the actual changing or substitution of the text of the scriptures with something not revealed. It is mentioned in the Qurān two times explicitly in connection with the Israelites living after Moses (Suras 2:59 and 7:162), in which it is clearly stated that evildoers among them 'substituted' (baddala) what was given to them by God with something else. According to the Qur'an, this intentional distortion of the scripture was not limited to the substitution of words in previously revealed texts; those who heard the new message also tried to corrupt it. In Sura 10:15, God instructs Muhammad to resist those who ask him to substitute (baddilhu) something else for the authentic revelations, either because they are too difficult or contradict the other scriptures. Instead, God tells him to say: "It is not for me to substitute it (ubaddiluha) [with something else] of my own accord..." Unlike the other forms of tahrîf found in the Qur'ān, tabdïl is unambiguously intentional: just as the unbelievers asked Muhammad to change the true revelations he was receiving, those who kept and interpreted previous scripture knowingly and deliberately altered what they had received. The seriousness of this accusation is obvious, and explains why later Christians and Jews felt the need to respond.

One should understand tahrïf, then, as an essential element of a comprehensive and coherent theory of revelation and divine justice. A shortcoming of some of the current scholarly work on this subject is the failure both to distinguish among the various types of corruption, and to understand the significance of each within this larger context. A common approach has been to emphasize the linguistic roots and the various meanings of the term, in order to support the particular theory of the origins of Islam that each researcher is seeking to defend. Consequently, the term tahrîf has been translated in different ways and often reflects the position of the scholar more than the intent of the text itself. These translations include 'falsification,' 'misinterpretation,' 'alteration,' or 'corruption,"22 all of which are sometimes correct, but can also lead to a misunderstanding of the purpose of the teaching. Too much emphasis on parsing terms can cause one to lose sight of the larger trajectory of the text and the intention of its author.

As we have seen above, the Qurānic understanding of revelation requires that an account be given of the obvious discrepancies (both minor and significant) between what Muhammad was receiving and the teachings and scriptures of the Jews and Christians. If God, out of mercy and justice, has revealed 
His divine will to prophets throughout human history, then all authentic versions of this revelation should be identical. But if the prophets have all received different messages, God cannot justly hold all people equally accountable. The teaching of tahrif offers an explanation of the existent discrepancies by placing the blame on human fallibility (and in some cases evil intentions), thus preserving God's integrity as just, merciful, and trustworthy. As a consequence, the Qurann is sent both to confirm what has been given before, and to remind people of the true revelation. All scripture and practice should therefore be judged and purified according to this Arabic revelation, which is presumably the final and perfect revelation so long as Muhammad's followers also take care that it is not corrupted.

Further support for the position that supersessionist teachings have their roots in the earliest period of Islam can be found in the writings of Christians living in the first two centuries after Muhammad. Along with those mentioned above who defended Christian doctrine and practice against Muslim efforts to convert them, one should add more well-known figures such as John, Patriarch of the Church of the East, John of Damascus, and the anonymous writer of the Treatise on the Trinity. The Damascene's systematic explanation of Christian faith, particularly his writings on the Trinity, is best understood within the wider context of the Umayyad conquest. His identification of Islam as a type of heresy is indicative of his opinion that the religion of the conquerors was a distinctive movement, one that saw itself as making truth claims that contradicted the teachings of orthodox Christianity and therefore required a lengthy rebuttal. ${ }^{23}$ Another example of someone who took up this problem is Abu Rāitịa al-Takrīitī, a Syrian Orthodox Christian who died around the year 830. He was one of the first to address the charge of tahrifif in a systematic way. Abu Ràitita took up the problem towards the end of his apology for the Trinity, where he presents a number of logical arguments against any suggestion that Christians and Jews have placed words into the mouths of the prophets, concealed what was revealed, or worse, substituted the words of revelation with other words. ${ }^{24}$ It is clear that all of these writers appear to have been engaged at a very early period in the defense of their beliefs and scriptures against attempts to replace them with the new revelation of the Qurān.

23 See, for example, Sandra Toenies Keating, "'Say Not Three': Some Early Christian Responses to Muslim Questions about the Trinity," The Thomist 74/1 (2010): 85-104.

24 Sandra Toenies Keating, "Refuting the Charge of Tahriif: Abū Rā’ița (d. ca. 835) and His 'First Risāla on the Holy Trinity'," in Ideas, Images, and Methods of Portrayal: Insights into Classical Arabic Literature and Islam, ed. Sebastian Günther (Leiden-Boston: Brill, 2005), $41-57$. 


\section{Conclusion}

The movement of reform put into motion by Muhammad in the early seventh century did not grow out of a simple desire to create a community of likeminded 'Believers,' nor is it the remnant of confused and misunderstood Jewish or Christian teachings floating around the Arabian Peninsula. The Qurān and the earliest teachings of Muhammad display a clear theology of revelation that, though not systematically presented, is concerned with establishing the credibility of the nascent community. Over time, it comes to be articulated in a way that emphasizes its supersessionist character. It is not, however, a type of supersessionism that desires to suppress or destroy monotheistic religions already in existence. In fact, it depends on them. Rather, this is a forwardlooking supersessionism, intent on incorporating Muhammad and his followers into the greater plan of salvation history. To do this, the Qurān insists on God's justice, equality among all believers, and equitable access to revelation. Nevertheless, without a notion of tahrîf, such a vision becomes nearly impossible to defend. 


\title{
Ibn Ḥazm's and al-Ghazzālī's Most Divergent Responses to Christianity: A Question of Epistemology and Hermeneutics ${ }^{1}$
}

\author{
Tamara Albertini
}

Muslims consider themselves the heirs of both Judaism and Christianity. However, the Islamic religion takes the Qur'ān to be a more faithful expression of divine revelation than the Torah or the Gospels, and therefore often 'corrects' biblical narratives. This has to do with the Islamic doctrine of tahrïf, which states that Jews and Christians have either distorted the 'wording' (tahrif al-nașs ) or the 'meaning' (tahrîfal-ma'ānì) of their respective sacred texts. The following Qurānic versions of some biblical stories are representative samples of the various types of 'discrepancies:'2

- Hawwa' (Eve) was not created from Adam's rib (this version only appears in the Hadith, Islam's second scriptural text). Also, she is not responsible for the Fall. Adam and Eve both disobeyed God and, accordingly, were punished equally. ${ }^{3}$

- Contextual clues in the Qur'ānic narrative suggest that Ismāîll (i.e., Ishmael, the ancestor of the Arabs through Hagar)—not Ishāq (Isaac)—was meant to be sacrificed (Q XXXVII, 102-105).

1 There is an earlier study of these two Muslim philosopher-theologians by Roger Arnaldez, "Controverses théologiques chez Ibn Hazm de Cordoue et Ghazali," Les Mardis de Dār el-Salām, Sommaire MCMLIII: 209-248. Arnaldez's study is very rich in information. It is, however, of a more descriptive nature and, accordingly, contributes little to the comparative approach taken in the present essay.

2 On 'Biblicizing' (the Qurānic narrative) and 'Islamicizing' (the Bible) as means for Islam's double appropriation of the biblical tradition, see Sidney H. Griffith, "Arguing from Scripture: The Bible in the Christian/Muslim Encounter in the Middle Ages," in Scripture and Pluralism. Reading the Bible in the Religiously Plural Worlds of the Middle Ages and the Renaissance, ed. Thomas J. Heffernan and Thomas E. Burman (Leiden: Brill, 2005), 29-58.

3 For the many relevant passages on Adam and Eve in the Qur'ān, see the section on "Anthropology" in Tamara Albertini, "Islamic Philosophy: An Overview," in The Companion to World Philosophies, ed. Eliot Deutsch and Ron Bontekoe (Oxford: Blackwell Publishers, 1997), 99-133, at 106-107. 
- King Suleymān (Solomon) is a Muslim, and Bilqīs (as the Queen of Sheba is known to Muslims) converts to Islam after meeting him (Q XXVII, 22-44).

- Maryam (Mary) grows up in the Temple where she is placed in the care of Zakariyyā (Zacharias) and receives religious education (Q III, 35-37). As in the Gospel she is a virgin-mother, but she has no male companion (i.e., no Joseph) and thus raises her son 'Īsā (Jesus) all by herself. As a result, she comes across as a much more independent figure than in Christianity.

- 'Isā is not the son of God, but just the son of Mary. Accordingly, his genealogy is reflected in his name, 'Tsā ibn Maryam, which may explain why Mary is the only woman in the Qur'ân to be called by name (for the identification of other female biblical figures one needs to rely on contextual clues). Therefore, Jesus cannot be one with God, which is why there may be no theological basis for the Christian doctrine of Holy Trinity in Islam. Muslims address Jesus as 'Sayyiduna 'İsă' (Our Lord Jesus) or 'al-Masịh' (The Messiah).

- As the Qurānic chapter named after Maryam states, Jesus performs his first miracle as a newborn by making a palm tree grow dates to help sustain his mother (Q XIX, 24-26). He also defends her against accusations of unchastity (Q XIX, 30-33).

- Finally, Jesus does not die on the cross (Q IV, 157). According to Islamic teaching, God would never submit one of his prophets to such humiliation and pain.

Clearly, the Qurānic narrative is not entirely compatible with the canonical books of the Bible. One should keep in mind, however, that the ancient Christian communities in Muslim lands happened to represent a great variety of Christological views and did not even agree on which books were canonical. Nevertheless, there is still sufficient overlap between the Muslim and Christian records to grant Mary and Jesus, for instance, a prominent place in Islam's sacred history. Many Muslim theologians go as far as to assign Jesus a major role on the Day of Judgment, a role second only to Prophet Muhammad. For this purpose, they rely on a hadīth (narration) preserved solely by Abū Hurayra, a close companion of the Prophet. Abu Hurayra, being the transmitter of over 5300 ahadith (pl. of hadith), was deemed a reliable source. Nevertheless, considering the extremely narrow textual basis, acceptance of the hadith in question by some leading theologians like al-Ghazzâlī may also be read as a testament to their veneration of al-Masīh.

The thesis of the present essay is that the degree to which Muslim theologians are at all prepared to examine Christian teachings, however critically, depends on a pre-existing hermeneutics. Basically, this entails that their attitude towards Christianity, and any other religion for that matter, is determined 
by the kind of scriptural exegesis used in their own schools of thought. The more sophisticated the hermeneutical approach applied to Islamic scripture, the more likely it is that non-Islamic scripture will also be subjected to exegetical scrutiny (rather than rejected or belittled from the outset because it contradicts certain Qurānic narratives). Within this context, the key terms to be explored are 'word' (lafza), 'meaning' (ma'nā), and 'intention' (niyya).

The first part of my paper examines Ibn Hazm (d. ca. 418/1027), who is frequently depicted as a literalist. The following discussion will shed light on the background against which he developed his (so-called) literalism. Rather than summarize his merciless critique of Christianity, as expounded in his Kitāb al-Fișal fi al-Milal wa al-Ahwā' wa al-Nihal (The Separator [Concerning] Religions, Heresies, and Sects), ${ }^{4}$ I will introduce his al-Risāla al-Bähira (The Magnificent Epistle) to uncover the 'authority-centered' epistemological basis of his theology, according to which Truth may solely be found in scripture. Furthermore, I will show the link between this epistemology and Ibn Hazm's linguistic theory, in which words rule over meanings. ${ }^{5}$ The second part of this essay focuses on the prominent Persian philosopher, theologian, and Sufi, al-Ghazzālì (d. 505/1111), whose 'subject-centered' epistemology, in which the seeker is required to validate Truth, permitted him to be inclusive and search for truth in all traditions, sacred or secular, without being limited by wording. This epistemology, moreover, opened the path to a hermeneutical receptiveness that remains unmatched in the Islamic world to this day.

\section{A Ibn Hazm, a Literalist or an 'Apparentist'? The Dominance of Words over Meanings}

Ibn Hazm was an Andalusian logician, theologian, moralist, and littérateur who belonged to the Zāhiri madhhab (=school of law), a school inspired by Dāwūd ibn Khalaf (d. 883), also known as al-Ẓāhirī. The name al-Ẓāhirī is derived from the Arabic word ' $z \bar{a} h i r$ ' (=apparent), as opposed to 'bātin'

4 An excellent discussion of this polemics may be found in Theodore Pulcini, Exegesis as Polemical Discourse. Ibn Hazm on Jewish and Christian Scriptures (Atlanta, Georgia: Scholars Press, 1998). See also Roger Arnaldez, "Controverses théologiques." For more literature see section on Ibn Hazm in David Thomas and Alex Mallett, eds., Christian-Muslim Relations. A Bibliographical History, vol. 3 (Leiden-Boston: Brill, 2011), 137-145.

5 Ibn Ḥazm, al-Risālah al-Bāhirah (The Magnificent Epistle), trans. Muhammad Saghir Hasan al-Ma'sumi (Kuala Lumpur: ISTAC, 1996). This is a different approach from Roger Arnaldez, who takes Ibn Hazm's Tawq al-Hamāma (The Ring of the Dove) to be the key to his thought. See his Grammaire et théorie chez Ibn Hazm de Cordoue. Essai sur la structure et les conditions de la pensée musulmane (Paris: J. Vrin, 1956, 21-23). 
(=hidden, concealed), and is taken to be synonymous with 'literal.' Zāhir and bāțin are paired in Qur'ānic exegesis to allow for (some) scriptural passages to have both an 'apparent' and a 'hidden' meaning, the latter term reflecting what al-Ghazzālī believed to be access to divine 'inner speech,' thus making the text of revelation the expression of God's outer (historic) word. ${ }^{6}$

In our context, the specific (and often overlooked) interest of the Zāhirī madhhab is that it introduced a third approach into the aforementioned dichotomy by differentiating between 'literal' and 'apparent. ${ }^{7}$ To give a concrete example, the frequent Qur'anic reference to the 'Throne of God' may then be read not only metaphorically or literally, but also according to its 'apparent' meaning. Ibn Masarra (d. 319/931), an earlier Andalusian philosopher and Sufi master, took the 'Throne of God' to be a scriptural metaphor for prime matter, thereby suggesting that the act of creation takes effect from where God governs the totality of Being. ${ }^{8}$ By contrast, the literal meaning conjures up the image of the Creator actually sitting, which would imply that God has a corporeal nature. For obvious reasons, literalists have often been attacked by rationalists in Islam, and vice versa. Yet, there is no good reason to think that the apparent meaning should be synonymous with the literal. In fact, this would betray the spirit of Zāhirite teaching that was all bent on fighting anthropomorphisms. To put it succinctly, a Zāhirī is not (necessarily) a literalist, but rather a scholar who rejects the need for a hidden meaning. The middle course therefore consists in focusing on what seems to be the obvious meaning, for instance, understanding that 'Throne' is merely a term used to underline divine majesty. Zāhirites thus succeed in avoiding the trap of an absurd literal reading or of having to assume the existence of a hidden meaning accessible to only few, such as the philosophers and the mystics. Moreover, the method allows the apparent meaning to be either a straightforward or a metaphorical expression. Basically, the school maintains that any Qurānic word or expression has but one meaning in the sentence in which it appears.

6 See Ebrahim Moosa, Ghazālī \& the Poetics of Imagination (Chapel Hill-London: The University of North Carolina Press, 2005), 148-153.

7 Ironically, after having been extinct for many centuries, the Zāhirī School is currently enjoying a comeback in the ultra-conservative Salafiyya scene, where it is being applied rather superficially in defense of a literalist reading of scripture.

8 Miguel Cruz Hernández, "Islamic Thought in the Iberian Peninsula," in The Legacy of Muslim Spain, ed. Salma Khadra Jayyusi (Leiden: Brill, 1992) $777-803$, at 778 . This is precisely the kind of reading denounced later by Ibn Taymiyya (d. 728/1328). In his view, Muslim philosophers who apply their Greek derived knowledge to Qurānic narratives are guilty of corrupting Islamic scripture, both by tabdīl and tahrîf. (See Thomas F. Michel, S.J., ed. and trans., A Muslim Theologian's Response to Christianity. Ibn Taymiyya's Al-Jawab al-Sahih (Delmar, N.Y.: Caravan Books, 1984, 21). 
A good example of eliciting the apparent (as opposed to the literal) meaning of a scriptural passage is when Ibn Hazm underlines that religious injunctions found in scripture apply to both men and women, even when the grammatical expression suggests male addressees only. Following Roger Arnaldez, A. G. Chejne sees Ibn Hazm make use of 'linguistic intuition' in this example, a basic technique consisting of mastering vocabulary, identifying the value of a word within a sentence, and determining the meaning of a word by placing it into the larger textual context. ${ }^{9}$ On a more profound level, Ibn Hazm's exegetical approach relies on his theory of languages as systems of meaning in which every word has an assigned meaning in a given context. Furthermore, the guarantor of univocality in language is God himself:

Any rational being knows that God... arranged languages and provided them with clarity. They consist of expressions resting on clear meanings of designated things. The Almighty God said: "We have not sent any messenger except with the tongue of his people so that he may make things clear to them." The tongue is the language, and there is no disagreement about that. But if speech did not clarify meaning, what things do the deserters of God and His Prophet understand, or with what do they understand each other? ${ }^{10}$

The particular interest of the above quotation is that Ibn Hazm manages to illustrate precisely his approach by pointing out that the apparent meaning of 'tongue' in the Qur'ānic passage cited (Q XIV, 4) does not refer to the muscular organ in one's mouth but to language.' While all languages are able to convey univocal content, the epitome of linguistic clarity is exemplified in scriptural (but not in literary or spoken) Arabic. According to Zāhirī teaching, the Qur’ān not only restores the original revelation once imparted to humankind's first prophets, but it also presents God's words in unambiguous Arabic, as it were, in its primordial purity.11 This explains why, unlike other Muslim theologians, Ibn Hazm did not think that the Bedouins' knowledge of Arabic, however pristine, could be trusted in elucidating scriptural language. Nor was he interested

9 A. G. Chejne, Ibn Hazm (Chicago: Kazi Publications, 1982), 116.

10 Ibid., 120, my emphasis.

11 Roger Arnaldez, Grammaire et théorie, 44-45. On the already existing difference between jurisprudential truth (haqiqa shariyya) and linguistic truth (haqiqa lughawiyya) in Islamic theology, see Ignaz Goldziher, Die Zähiriten. Ihr Lehrsystem und ihre Geschichte. Ein Beitrag zur Geschichte der muhammedanischen Theologie (Leipzig, 1884; repr. Hildesheim: Olms, 1967), 128. 
in tracing the common trilateral roots of scriptural terms in order to elicit their meaning, which represented another common technique borrowed from the Grammarians. Also, Qurānic terms were not to be categorized by genera and species as in Greek logic, but by their meanings, which consequently prompts the question as to how 'meaning' is then to be uncovered.

As Roger Arnaldez has been able to show, Ibn Ḥazm distinguishes between a primary (murād) and a secondary (maqsūd) purport of words (alfāz, pl. of lafza). While the Andalusian recognizes that authors may coin a term by introducing a secondary purport, his focus lies on the primary purport, which is essentially the sense $\left(m a^{\prime} n \bar{a}\right)$ of a word, determined not by an idea or an image but by the word itself and its 'meaning-carrying' intention ('intention significative,' niyya). Basically, Ibn Hazm excludes both the extraneous meaning and the psychological intention that language users introduce in their private vocabulary. ${ }^{12}$ Words are therefore not guided by thought; rather, they determine meanings. Accordingly, truth is not external to the meaning God placed in words.

This extreme nominalism, anchored in the notion that God clarified meaning through the very wording of his revelation, also explains the Zāhirī rejection of qiyās (analogical reasoning) as introduced by Abū Ḥanīfa (d. 150/767), the founder of the Hanafi madhhab, Islam's first and most progressive school of law. Zāhirītes only consider the Qur'ān, Hadìth, and the ïmmác (consensus) of Muhammad's immediate Companions as legitimate sources of law. All other sources are considered bid'a (prohibited innovation). In his Risāla al-Bāhira (The Magnificent Epistle) Ibn Hazm even underlines that the Companions who joined the Prophet on his escape from Mecca to Medina take precedence over later contemporary followers. ${ }^{13}$ And yet, how is one to demonstrate that these are truly the exemplars of knowledge in Islam? Or, put differently, how does one show the futility of the question that asks who among the founders of Islam's (Sunni) schools of law "is grander (ajall), more excellent (afdal), more pious $(a w r a)$, more versed in jurisprudence (afqah), and more knowledgeable

\footnotetext{
12 Ibid., 57.

13 Ibn Ḥazm, al-Risālah al-Bāhirah, 41. The Companions mentioned by name are 'Umar ibn al-Khațāāb (Islam's third Khalīf), the Mother of the Believers 'Ā'isha (the Prophet's favorite wife), 'Alī ibn Abī Tālib (Islam's fourth Khalīf), 'Abd Allāh ibn Mas'ūd, and 'Abd Allāh ibn 'Abbās (a cousin of the Prophet). One cannot help but notice the prominent position given to 'Â'isha. She is on par with the other Companions in respect to "excellence in knowledge, sagacity, grace, and piety" (ibid.).
} 
(alam)?"14 To opponents raising this question, Ibn Hazm replies sharply that they are obviously unable to judge the words (alfäz) used in their own phrasing:

You are ignorant of their meaning ( $\left.m a^{\prime} n \bar{a}\right)$, you do not master their subject $(m a w d \bar{u})$, you do not understand their truth (haqiqa), you do not know their purport (murād bihi), and you do not comprehend their [philological] exegesis $($ tafsir $) .{ }^{15}$

This brief quotation from the beginning of the Risāla al-Bāhira contains nothing less than Ibn Hazm's methodology. What then follows it in the Risäla is an exercise showing how to extract the meaning of words in order to assess their juridical applicability. To mention but one semantic analysis, the Andalusian specifies that the Arabic word 'jalāla' (majesty, same root as ajall, the word translated above as 'grander') refers either to one's rank in society or to one's rank among the believers. Since the first meaning would make no sense in the interrogative sentence cited earlier, while the second one remains necessarily unknown to human beings, Ibn Hazm concludes that the very wording of his opponents' question is inadequate. ${ }^{16}$

It is, therefore, absurd to ask who ... is more learned—Mālik, Abū Ḥanīfa, Shāfììi, Aḥmad or Dāwūd. This question carries no sense, no significance, and is just to care for something useless. No reasonable person will intrigue in a case like this. ${ }^{17}$

Ultimately, the question carries no sense because true knowledge ('ilm) - as needed for legal injunctions - may never be derived. Only the wording found in statements collected directly from a select group of Muhammad's Companions qualifies as such a basis. Therefore, derived knowledge such as in

14 For the original Arabic, see ibid., 100. I have used my own translation, since al-Ma'sumi's rendering of the key words in this passage (ibid., 38) is not consistent with the rendering of the same words later in the text.

15 For the original Arabic, see ibid., 101. Al-Ma'sumi shortens this passage in his rendering (ibid., 38) and seems to be unaware of the importance of the technical terms in it, which is why I offer my own translation. Ibn Ḥazm allows for tafsīr but not ta’wīl (allegorical exegesis).

16 Ibid., $65^{-67 .}$

17 Ibid., 40. The names refer to founders of Sunni schools of law: Mālik ibn Anas (d. 179/795), Abū Ḥanīfa, al-Shāfīīi (d. 205/820), Aḥmad ibn Ḥanbal (d. 241/855), and Dāwūd ibn Khalaf al-Ẓāhirī. 
the outcome of analogical reasoning, which necessarily departs from scriptural wording, is a mere opinion and consequently without authority. As a result, even the views expressed by the venerable founders of Islam's schools of law, including Dāwūd, are not legally binding. ${ }^{18}$

The Magnificent Epistle exemplifies what I meant by Ibn Hazm's 'authoritycentered' epistemology in the beginning of the present essay, the 'authority' being the scriptural content as reflected in the concise wording of divine revelation. This is the epistemology that also determines the hermeneutics used by the Andalusian theologian, as well as the background without which one could not possibly situate Ibn Ḥazm's most polemical work, Kitāb al-Fișal, a treatise examining other world religions, in particular Judaism and Christianity. Here, his condemnation of Christian beliefs belongs to the harshest statements one may find in Islam, surpassing in sharpness even the accusations of Ibn Taymiyya.

Theodore Pulcini provides the following list of epithets used by Ibn Hazm in reference to Christians: stupid, irrational, frivolous, impious, lying, obstinate, blindly submissive to authority, arbitrary on belief and practice, avaricious, inferior, and theologically extremist. ${ }^{19}$ Except for 'avaricious,' which the Andalusian uses in reference to Church leaders whose greed he (rightly) accuses, all other epithets suggest that Ibn Hazm is questioning the orthodoxy and orthopraxy of Christians in the same way he would when scrutinizing Muslims following schools of thought different from his own. A typical example for what he takes to be the Christian lack of 'rationality' (logic) may be found where Ibn Hazm is baffled that Christ should be seated at the right hand of God the Father and also be God himself,, ${ }^{20}$ or similarly, that the Father is the Son and the Son is the Father, making a relative relationship turn into a reciprocal one. ${ }^{21}$ Furthermore, the Andalusian also detects numerous contradictions among the Gospel passages, which he imputes to the lack of an abrogative

18 In fields other than theology, Ibn Hazm's position is remarkably different. In his Categories of the Sciences (Marätib al-'Ulüm) he thus underlines: "For the one who speaks on his own authority and on the basis of what he thinks is not the same as the one who speaks on the authority of someone else. A bereaved mother is not the same as a hired mourner. And he who listens to one scholar only will get almost nothing; he would be like the one who persists drinking from one well containing turbid salt, having abandoned sweet and fresh water were he to drink from other wells. Engaging one's equal and opposing enemies in debates that truth can be discerned from falsehood. There is no other way" (A. G. Chejne, Ibn Hazm, 203).

19 Pulcini, Exegesis as Polemical Discourse, 164.

20 Roger Arnaldez, "Controverses théologiques," 221.

21 Ibid., 220. 
methodology (naskh) in Christian theology. ${ }^{22}$ Finally, he also points out the absence of a sound chain of transmission to help create scholarly consensus $\left(i j m \bar{a}^{c}\right) \cdot{ }^{23}$

The greatest difficulty Ibn Ḥazm faces when approaching Christian scripture has to do with metaphors, parables, and other didactic means used in the Gospels. As Pulcini explains:

For example, according to the Christian scriptures, Christ specifically told his disciples that anyone who becomes angry with his brother is liable to judgment and that anyone who sins with his right eye should pluck it out (cf. Mt. 5:22,29). These, Ibn Ḥazm contends, are clear legal prescriptions from Christ, yet Christians feel no obligation to comply; in failing to obey, they contradict Christ himself. ${ }^{24}$

Whereas Christians read the referenced passages as hyperboles, Ibn Hazm takes them to be religious injunctions with legal force. Essentially, he responds to the quoted Gospel lines in the same way as he would to a verse from Islamic scripture. From where he stands, Christians (who do not make use of the same methodology) are therefore necessarily stupid, irrational, impious, lying, obstinate, arbitrary on belief and practice, inferior, and theologically extremist. Evidently, St. Paul's emphasis on the Spirit of the Law (as opposed to the Letter of the Law, 2 Cor. 3:6) was alien to Ibn Hazm's world of thought.

To answer the question posed in the title of this section, Ibn Hazm can therefore be seen as both an 'apparentist' and a literalist. In respect to his own scriptural tradition, his exegetical goal is to extract the apparent meaning. However, when he applies himself to non-Islamic scriptures such as the Gospels, Ibn Ḥazm takes all non-straightforward expressions à la lettre. In his defense, one may say that since he had to rely on Arabic translations of the Gospels (he mostly focuses on St. Matthew's account) ${ }^{25}$ and had no knowledge of any of the languages relevant to biblical studies (Hebrew, Aramaic, Greek, and Latin), he was in no position to make use of linguistic intuition. It is more

22 Ibid., 226. The Qur'ān is a self-referential text that comments on earlier revealed verses. Naskh is the Islamic exegetical principle that determines which Qurānic verses may be invoked to abrogate, i.e., modify, other verses. For instance, a general principle may require modification in response to historic circumstances.

23 Ibid., 234.

24 Pulcini, Exegesis as Polemical Discourse, 135.

25 For the translation Ibn Hazm most likely used, see Pulcini, Exegesis as Polemical Discourse, $185^{-187 .}$ 
than likely, however, that if Ibn Hazm had been able to read the original Gospels, he would still have insisted on interpreting any imperative phrasing as a divine command ( $a m r)$.

\section{B Al-Ghazzālī: Journeying beyond Words to Reach Meanings}

A very different tone emerges from al-Ghazzālì's writings, which is not to say that the Persian philosopher could not be a polemicist as well. It suffices to mention his harsh invective against the Bāținites, as the Ismāîlīs were called in his native region, or his Tahäfut al-Falāsifa (Incoherence of the Philosophers), in which he brilliantly argues against twenty theses he singled out from the works of the Peripatetic philosophers al-Fārābī and Ibn Sīnā because they challenged or contradicted orthodox Islamic teaching. On the whole, however, al-Ghazzāli appropriates, adapts, and integrates non-mainstream Islamic as well as nonIslamic sources whenever he recognizes the intrinsic value of their teaching, be it a concept, a single statement, or a metaphor. This is in keeping with the strict criteria for certainty formulated in his al-Munqidh min al-paläl (The Deliverance from Error), the autobiography he wrote upon returning home from years of wanderings as a humble Sufi. ${ }^{26}$

In terms of ancient sources, al-Ghazzālī seems to have had a predilection for authors from the Roman period. Thus, without mentioning the name of the Stoic philosopher Epictetus, he expands the latter's sea voyage metaphor in which passengers disembark on an island with some interrupting the journey all together, the island being a metaphor for the trappings of earthly existence. At other times he describes himself as a diver for truth, tacitly borrowing the metaphor from Diogenes Laertius (who attributed it to Socrates). ${ }^{27}$ Naturally, al-Ghazzālī also makes frequent references to themes, terms, and teachings derived from pre-Islamic Persia, such as the Zoroastrian metaphysics of light. As if he had anticipated the attacks of the later Ibn Taymiyya for having dared to quote the verses of a Christian Arab poet in support of there being an 'inner speech' of God, al-Ghazzālī took great efforts to clarify his approach to truth in

26 Al-Ghazali, Deliverance from Error. Five Key Texts Including His Spiritual Autobiography al-Munqidh min al-Daläl, trans. and annot., Richard Joseph McCarthy (Louisville: Fons Vitae, 2004), 57 .

27 Cf. Tamara Albertini, "Mystical Landscapes-Places of the Mind. Emptiness and Plenitude in Islamic Philosophy," in Labirinti della mente. Visioni del mondo. Il lascito intellettuale di Elémire Zolla nel XXI secolo, ed. Grazia Marchianò (Siena: Società Bibliografica Toscana, 2012) 175-190, at 184, 185 . 
The Deliverance from Error: knowledge is not to be defined by identity. ${ }^{28}$ In other words, the provenance of a statement or an insight may not influence either its acceptance or rejection. In the same way as a well-trained magistrate listens to all voiced opinions without adopting any before due scrutiny, the philosopher too is under the obligation to remain impartial when searching for truth in different traditions. To support this, the Persian philosopher cites a famous saying: "Do not know the truth by men, but rather know the truth and you will know its adherents." ${ }^{29}$ The statement is quite poignant, also for the fact that it happens to be a quotation of 'Alī ibn Abī Țālib, Islam's fourth Khalīf and the revered first Imam of the Shī'a. Al-Ghazzāli goes one step further in his uncompromising and impartial embrace of truthfulness, claiming that it is to be acknowledged even where it is mingled with obvious falsehood or errors. Regarding the Ikhwān al-Ṣafā (The Brethren of Purity), another group of Shī'ites for whom he had little sympathy, he thus writes: "If we were... to aim at forgoing every truth which had been first formulated by the mind of one in error, we would have to forgo much of what is true." ${ }^{30}$ What al-Ghazzālì meant to express is that, although he had many issues with the teaching of the Ikhwān, he still gave them credit for citing or deriving truthful statements from scripture, Sufi teachings, and other authoritative sources. Not surprisingly, the Persian philosopher therefore had no difficulty in both accepting and rejecting the statement of a Christian affirming "there is no God but God; Jesus is the apostle of God," i.e., recognizing the validity of the monotheistic creed but objecting to Jesus (rather than Muhammad) being the Apostle of God.

Hence, if he [the Christian] is an unbeliever only because of his denial of the latter [Muhammad's prophethood], he should not be contradicted in matters other than what he disbelieves. I mean something which is true in itself, although the Christian also holds to be true. ${ }^{31}$

Put in a different way, if one were to reject the entire Christian creed, this would also apply to its true portion, i.e., the assertion that God is one. It is tempting to think that al-Ghazzālī had a favorable bias towards Christianity, certainly more favorable than towards the Shi'a. However, this is not the same as having any particular leaning for Christian teaching. Instead, as the following will show, it was al-Ghazzālì's 'Islamized' understanding of Jesus that facilitated a benign attitude towards Christianity.

\footnotetext{
28 Ebrahim Moosa, Ghazālī \& the Poetics of Imagination, 148-153.

29 Al-Ghazali, Deliverance from Error, 68.

$30 \quad$ Ibid., 69 .

31 Ibid., 68, my emphasis.
} 
To return to al-Ghazzâlī's notion of knowledge, a precondition for the one who earnestly desires to find truth in any tradition is to uncover the meaning (ma'na $)$ of a teaching, statement, or injunction. In tune with his ethics, in which the intention (niyya), not the outcome of an act, serves as the measure of one's deeds, the Persian philosopher analyzes Christian Trinitarian teaching in light of what it is designed to convey. Here is his analysis from one of his epistles:

When Christians refer to God as the third of the three, they do not mean that God is [numerically] three... indeed God is one in his essence [dhāt] and three with respect to his attributes [șifât]. And this is the wording of their statement: One in substance [jawhar] and three by way of hypostasis [uqnümiyya]. By 'hypostasis,' they mean attributes. ${ }^{32}$

Al-Ghazzālī is remarkably accurate in rendering the early Christian Trinitarian understanding; some of his wording sounds like a gloss or may possibly be a direct quotation of a Christian source. ${ }^{33}$ Notably, he explores the creed without condemning it beforehand or 'correcting' the message it conveys. He focuses instead on what 'they mean' to express, not what the creed says verbatim. In stark contrast to Ibn Hazm, al-Ghazzāli thinks wording is secondary to intention. For him, the hermeneutical challenge consists in discovering the psychological intention of the author (human or divine), rather than the intention attached to the meaning that the words themselves carry.

Regarding his fellow theologians (mutakallimūn), it is not surprising that al-Ghazzâlī says that they ably defended orthodoxy but utterly failed in arriving at primary and self-evident truths:

They relied on premises which they took over from their adversaries, being compelled to admit them either by uncritical acceptance, or because of the Community's consensus, or by simple acceptance derived from the Qur'ān and the Traditions. ${ }^{34}$

32 Ebrahim Moosa, Ghazālè \& the Poetics of Imagination, 149, my emphasis. In this statement al-Ghazzâli tacitly applies the two categories of divine names in Islam: those that refer to God's essence, and names that are divine attributes.

33 Roger Arnaldez makes reference to an earlier researcher who showed that al-Ghazzālì had consulted a Coptic version of St. John's Gospel during his stay in Egypt. See his "Controverses théologiques," 245-246.

Al-Ghazali, Deliverance from Error, 59 . 
Scripture is considered a source of knowledge, but not knowledge itself. Its truth only makes itself manifest to the one who validates knowledge, either by the use of (critical) credence in other people's testimony (immann), apodeictic proofs, or mystical fruition (dhawq) - basically, by one of the three degrees of knowledge with which the seeker may gain certainty of the veracity of a teaching. ${ }^{35}$

Al-Ghazzālī's 'subject-centered' epistemology accords with the hermeneutical recommendation he issued in his magnum opus, the Ihya a Ulüm al-Din (The Revival of Religious Sciences):

If you examine the writings of anyone who had gained distinction in knowledge, then do not so with condescension... And do not stop where the author's text ends. For, surely, meanings are more expansive than their literal expressions, and the bosoms [hearts] are more capacious than compiled books, for there is much knowledge in what is not articulated. So aspire to grasp all the possible meanings of his writing with the perception of his heart. ${ }^{36}$

There could not be a clearer invitation to explore a text beyond its mere verbal expression. A very different approach, however, may be found in his al-Durra al-Fäkhira (The Precious Pearl), a short eschatological treatise that the Persian philosopher wrote for a wider audience. In it he envisages God summoning Jesus son of Mary on the Day of Judgment to 'recite' the Gospel. Jesus complies and "he brings the Gospel fresh and new, so that even monks think that they have never known one verse of it." ${ }^{\prime 3}$ While al-Ghazzālī remains faithful to the Islamic position that takes the historic Gospel text to be a corrupted version of a pre-existing original, he is careful not to state what the differences between the two versions might be. Instead, he has Jesus most delicately make one single 'correction.' This approach is quite different from Ibn Hazm and Ibn Taymiyya, the latter of whom had once bluntly declared: "And the Christians have erred in the denotation [musammā] of speech [kalām], so they made the messiah [Jesus] self-sufficient, who is then identical to the word of God." ${ }^{38}$

35 Ibid., 82.

36 Ebrahim Moosa, Ghazālı̀ \& the Poetics of Imagination, 114.

37 Jane Idleman Smith, The Precious Pearl. A Translation from the Arabic with Notes of the Kitāb al-Durra al-Fākhira fì Kashf Ulūm al-Ākhira of Abū Hāmid Muhammad b. Muḥammad b. Muḥammad al-Ghazālī (Harvard University: Scholars Press, 1979), 67. 
Obviously, The Precious Pearl does not include the 'original' Gospel. The only change it reflects is the one applied to the notion of Holy Trinity. Thus, before God instructs Jesus to recite the Gospel he asks him: "Did you say to people 'Take me and my mother as gods, apart from God?'” To this Jesus responds:

It is not for me to say what I have no right to say. Had I said it, You would have known it. You know what is in my soul, though I do not know what is in Yours. ${ }^{39}$

Al-Ghazzālì's reaction to Christian Trinitarian teaching in The Precious Pearl is noticeably different from the one expressed in his epistle. In the eschatological treatise composed for the non-specialist, no attempt is made to assess the possible compatibility between Christian and Islamic teachings. Like all welltrained Muslim theologians, al-Ghazzālī is careful not to confuse or put doubt in the mind of believers, who may be insufficiently trained or lack intellectual aptitude to discuss the 'inner meaning' of a scriptural text, either Islamic or Christian for that matter. Remarkably, though, Jesus does not explicitly reject the notion of Holy Trinity in The Precious Pearl. All he does is clarify that he never meant that he and his mother should be divinized. In other words, the Persian philosopher has Jesus only address the vulgarized version of Holy Trinity, which mentions Mary as the third divine person instead of the Holy Spirit. Another point of interest is Jesus's Islamized features. For instance, he is called upon to recite the Gospel the way Muslims ritually chant the Qur'àn from memory. Also, Jesus (who leads the poor on the Day of Judgment) is lauded for his poverty, not for his love, charity, or compassion.

Learn a lesson from the messiah, for it said that he had no purse at all, that he was dressed in the same woolen garment for twenty years, and that in his travels he had only a small mug and a comb. One day he saw a man drinking with his hand, so he threw the mug from his hand and never used it again. Then he passed by a man running his fingers through his beard, so he threw away the comb from his hand and never used it after that. ${ }^{40}$

39 Smith, The Precious Pearl, 67. This is a direct scriptural quotation (Q V, 116).

$40 \quad$ Ibid., 77. 
In al-Ghazzālī's version, when Jesus encounters individuals poorer than he is, he does not offer them his few possessions. Instead, the mug and comb are merely tossed away. Jesus thus comes across as the embodiment of Islamic asceticism from the period preceding the rise of Sufism, i.e., Islamic mysticism, of which al-Ghazzālī stated that its greatest achievement was its injection of love into Islamic spirituality. Therefore, it may not be a coincidence that only two pages after the above quotation, the Persian philosopher cites the famous Muslim ascetic Hasan al-Bașrī, who lived precisely at the time when Islamic asceticism transformed into a mystical movement. From a Christian point of view, one might say that Jesus's poverty was the expression of his love for humankind and that love is therefore the dominant element in Christ's teaching. However, one should also bear in mind that asceticism was a particularly salient feature of Eastern Christianity, which would explain al-Ghazzāli's great emphasis of Jesus's own ascetic lifestyle in the Precious Pearl. Christ's love (of God), however, is greatly alluded to in another work of al-Ghazzālì's.

In Love, Longing Intimacy and Contentment (Kitāb al-Mahabba wa al-Shawq wa al-Uns wa al-Rida $)$, another book of the Ihy $\bar{a}^{3}$ and with a strong emphasis on Sufism, al-Ghazzālī speaks of Jesus as one of God's preferred prophets. He explains the matter by stating: "it was based on the graciousness he [Jesus] had witnessed in the stage of intimacy." ${ }^{41}$ 'Intimacy' is translated from 'uns,' a technical term of Islamic mysticism that al-Ghazzāli interprets as the exultation of the heart that experiences closeness to God. ${ }^{42}$ The language used in Love, Longing Intimacy and Contentment clearly indicates that Christ is taken to be a mystic. Moreover, Jesus's preference for the longing for heaven over the fear of hell, and for the love of God over the desire for heaven, ${ }^{43}$ is reminiscent of a saying attributed to Rābi'a al-'Adawiyya (d. 185/801), one of Islam's earliest mystics, whose loving memory the Persian philosopher helped preserve:

I am going to light a fire in Paradise and to pour water on to Hell, so that both veils (i.e., hindrances to the vision of God Himself) may vanish altogether from before the pilgrims and their purpose may be sure, and

41 Al-Ghazālī, Love, Longing Intimacy and Contentment. Kitāb al-mahabba wa al-shawq wa al-uns wa al-rid̄ā, Book XXXVI of the Revival of the Religious Sciences Ihyä' 'ulüm al-dīn. Translated with an Introduction \& Notes by Eric Ormsby (Cambridge: The Islamic Texts Society, 2011), 142, my emphasis.

42 Ibid., 133. More passages mention the Sufi heart (qalb) in relation to Jesus; see 159, 185 , and 190.

Ibid., 37 . 
the servants of God may see Him, without any object of hope or motive of fear. ${ }^{44}$

Unlike Ibn Hazm, who squarely opposed the Christian notion of Jesus's divinity, al-Ghazzâli teases out a 'meaning' that keeps the communication lines open between Islam and Christianity. Jesus the Sufi is a judicious solution allowing for an allusion to the 'divinity' of Christ in terms that are agreeable if not to all Muslims, at least to those receptive to mysticism. However, an oblique comment inserted in Love, Longing Intimacy and Contentment in reference to a statement made by the crucified Muslim mystic al-Hallāj (d. 309/922) clarifies that the Persian philosopher was not prepared to go as far as to accept the concept of incarnation..$^{45}$ For al-Ghazzālī, Jesus was the intimate of God whose Self was possibly annihilated or absorbed into God. He may even grant Jesus that he experienced the "exchange of attributes" (tabaddul al-sifät) ${ }^{46}$ a mystical transformation al-Ghazzālī speaks of in his autobiography and that entails the surrender of one's human nature to God without entering into a full-scale union with the Creator. While this interpretation may not satisfy Christians, it nevertheless remains the expression of a Muslim scholar anxious to root Christianity in a religious experience common to both Christians and Muslims. Al-Ghazzālī achieved this by taking the subjective experience of a Sufi filled with the presence of God as an explanation for the Christian notion of Jesus's divinity. His approach exemplifies superbly that understanding each other across different religions and cultures does not begin by fighting over words, but by attempting to agree over meanings.

44 Margaret Smith, The Way of the Mystics. The Early Christian Mystics and the Rise of the Süfis (New York: Oxford University Press, 1978), 187-188.

45 Al-Ghazālī, Love, Longing Intimacy and Contentment, 39-40. This is a view one finds expressed also in Al-Radd al-Jamill lī-Ilāhiyya 'Tsà bi-Sarīh al-Injül (The Fitting Refutation of the Divinity of Jesus Through What Is Evident in the Gospel), a short treatise that some scholars take to be an authentic work by al-Ghazzālī (for more details see section on al-Ghazzālī in Thomas and Mallett, Christian-Muslim Relations, vol. 3, 367-369). The style, syntax, and vocabulary used in Al-Radd al-Jamïl are very different from al-Ghazzālī's writing in his other theological works. I, therefore, see no basis to confirm his authorship. Besides, since al-Ghazzālī's interpretation of Jesus as a Sufi master is sufficiently evident in the Ihyä'Ulüm al-Dīn, the present essay has no need of Al-Radd al-Jamill to make that case.

Al-Ghazali, Deliverance from Error, 78. 
One may never establish with certainty whether al-Ghazzālī single-handedly cut the stones needed to build a bridge between Christianity and Islam, or whether he adapted pre-existing, possibly non-mainstream, Christological notions to his interpretation of Jesus the Sufi. What matters in the end is that the Persian philosopher successfully crossed that bridge, and that many more may also endeavor the passage—in both directions. 


\title{
Jesus in the Muslim and Christian Mystical Traditions: Ibn 'Arabi and Meister Eckhart
}

\author{
RobertJ. Dobie
}

The writings of the great mystical thinkers have become a common starting point for interreligious dialogue, no less so in Muslim-Christian dialogue. This is due to the reputation of mystical writers for pushing the doctrinal limits of their own religious traditions and of therefore 'going beyond' them. ${ }^{1}$ There is certainly something valid in this reputation, as can be exemplified by the great Andalusian Sufi Muhyaddin Ibn 'Arabi (1165-1240), who writes in his collection of erotic-mystical poetry, the Tarjiman al-Ashwaq or "The Interpreter of Desires:"

O Marvel! a garden amidst the flames

My heart has become capable of every form:

It is a pasture for gazelles and a convent for Christian monks,

And a temple for idols and the pilgrim's Ka'aba,

And the tables of the Torah and the book of the Qur'an.

I follow the religion of Love: whatever way Love's camels take,

That is my religion and my faith. ${ }^{2}$

Opened by ecstatic love, the heart of the Sufi is described as a receptacle for all that leads to God. What is more, for Ibn 'Arabi, as for many Sufis, Jesus is the model for such radical receptivity and love. Ergo, a natural place to look for convergence and commonality between Christians and Muslims would be to look at the meaning of Jesus in speculative Sufism, of which the thought of Ibn 'Arabi is probably the best example.

1 For a good discussion of ways in which this often has happened, even (or especially) in the Middle Ages, see James Heft, S. M., Reuven Firestone, \& Omid Safi, eds., Learned Ignorance: Intellectual Humility among Jews, Christians, and Muslims (Oxford: Oxford University Press, 2011), and Barbara Roggema, Marcel Poorthuis, \& Pim Valkenberg, eds., The Three Rings: Textual Studies in the Historical Trialogue of Judaism, Christianity, and Islam (Leuven: Peters, 2005), 141-62.

2 R. A. Nicholson, trans., The Tarjuman al-ashwaq: a Collection of Mystical Odes by Muhyiddin Ibn al-'Arabi (Ulan Press, 2011), 67. 
What we shall argue in this essay, however, is that the way a Muslim Suf like Ibn 'Arabi understands the figure of Jesus opens up gaps and reinforces doctrinal lines between Christianity and Islam as much as it closes and blurs them. ${ }^{3}$ The most fundamental question that Ibn 'Arabi's work proposes to MuslimChristian dialogue is this: is creaturely finitude an absolute and insurmountable obstacle to union of the human soul with God, or is creaturely finitude in some way 'redeemable' and even a necessary instrument of such union? As we shall see, Ibn 'Arabi's meditations on the meaning and significance of the 'prophethood' of Jesus expose stark differences with the Christian understanding of Jesus, which do not fit easily into any discourse of the universality of the mystical path. By way of contrast, we shall also look at the thought of a Christian mystic who was close in time as well as in spirit to Ibn 'Arabi-the Dominican friar Meister Eckhart (c.1260-1328). Examining some key themes from Eckhart's mystical writings should help us locate precisely the points of similarity and difference in Christian and Muslim approaches to the figure of Jesus.

\section{Jesus as the Essence of Prophecy in Ibn 'Arabi}

In the Sufi tradition, the prophetic figure of Jesus does not merely illustrate one 'specific and narrowly definite moral type', but rather, he illustrates the fullness

3 The same Ibn 'Arabi who wrote such beautiful and irenic poetry about how divine love can transcend religious boundaries also wrote a letter to the sultan of Konya exhorting him to apply sharia law in its full rigor to his non-Muslim subjects, restraining any public manifestations of the Christian faith lest they make "public show of their polytheism." He adds, "The worst thing that Islam and Muslims suffer in your realm is the sound of bells, the manifestation of infidelity, the affirmation of an associate of God, and the disappearance of the rules instituted by the Prince of Believers, 'Umar b. al-Khattab, regarding dhimmis: namely that neither in the city itself nor in the surrounding regions are they to build new churches, monasteries or hermitages, that they are not to prevent any Muslim from being given food and shelter in their churches for a period of up to three days, that they are not to hide spies, that they are not to conspire in secret against Muslims, that they are not to teach the Qur'an to their children, and that they are not to make public show of their polytheism" (Claude Addas, The Quest for the Red Sulphur, trans. Peter Kingsley (Cambridge: Islamic Texts Society, 1993), 235). This letter should disincline us against constructing a facile narrative of some sort of 'mystical harmony' of religions, which could so hastily be concluded from the passage cited earlier from Ibn 'Arabi's Tarjiman. Ibn 'Arabi, of course, was not just a great Sufi thinker and master but also a man of his time. As a Muslim refugee from the Christian Reconquista of Spain, his views on practical relations between Muslims and Christians would have no doubt been strongly tinged by these conditions and experiences. Cf. Abdelilah Ljami, Ibn Hazm et la polémique Islamo-Chrétienne dans l'histoire de l'Islam (Leiden-Boston: E. J. Brill, 2003). 
of the prophetic type, combining asceticism, a warm human wisdom, and miraculous powers, particularly that of raising the dead. ${ }^{4}$ Indeed, Jesus becomes something like the 'patron saint ${ }^{5}$ of the Suf tradition, and nowhere is this clearer than the important role he plays in the thought of the most philosophically sophisticated of the Sufi mystics, Ibn 'Arabi. The significance of Jesus as teacher and (Muslim) prophet is key to Ibn 'Arabi's thought, and Jesus as prophet is a central figure in his most famous work, The Bezels of Wisdom. In this work, Ibn 'Arabi regards the twenty-six prophets mentioned in the Qur'an - starting from Adam and ending with Muhammad-as 'bezels' or gem-settings, into which the various 'gems' or facets of the divine Essence are set. Each facet is, in turn, a 'word' (kalima) that 'breathes forth' and 'expresses' an aspect of divine wisdom that otherwise cannot be expressed or known in the ineffable unity of the divine Essence, but which the prophet expresses in both his life and in his message. Thus, the text has headings with titles such the 'wisdom of divinity' in the 'word of Adam' and the 'wisdom of light' in the 'word of Joseph' (who, as interpreter of dreams, casts light on the meaning of creaturely significations). In this collection of Biblical and Qur'anic prophets, Jesus holds a central place, for the 'wisdom of prophecy (nabawiyya)' resides in his 'word.' In other words, Jesus incarnates the essence of prophecy in a book that is about prophets, placing each in a setting (or bezel) for a divine word.

This preeminence of Jesus is due to his having incarnated the spirit $(r u h)$ of God in a wholly manifest way. As the Qur'an itself teaches, Jesus was born of the spirit of God blown into the Virgin Mary by the angel Gabriel. Hence, Jesus does not have a father made of flesh and blood, but is instead a direct creation of the spirit of God. It should be noted, of course, that for the Muslim Ibn 'Arabi, Jesus is still a creature and that the spirit is not God in any personal or univocal way. But Jesus does manifest in a particularly striking way how the divine spirit or 'breath' permeates, quickens, and animates the universe, for most prominent among Jesus's miracles was his ability to raise the dead: "Now the measure of life that pervades a creature is called divine, humanity being [preeminently] the locus in which the Spirit inheres. Thus humanity is called a spirit by virtue of that which inheres in it." ${ }^{\prime \prime}$ In a special way then, Jesus as prophet manifests both God's immanence in creation, as the breath or spirit

4 Tarif Khalidi, The Muslim Jesus: Sayings and Stories in Islamic Literature (Cambridge, MA: Harvard University Press, 2001), 29.

5 Khalidi, The Muslim Jesus, 34.

6 Ralph Austin, trans., The Bezels of Wisdom (Mahwah, NJ: Paulist Press, 1980), 175. References to the Arabic text are from Abulailah Affifi, ed., Fusus al-hikam (Beirut: Dar al-Kitab al-Arabi, 2002), 138-39. 
that animates it, as well as God's transcendence, insofar as Jesus is a mere creaturely manifestation.

In order to understand how Jesus functions in Ibn 'Arabi's mystical thought, we must first look at its general metaphysical/theosophical framework. Fundamental to Ibn 'Arabi's thought is his assertion of the wahdat al-wujud, or the 'unity of being (existence).' According to Ibn 'Arabi, existence in itself is one and undifferentiated. God, as one, is Existence in Itself. Creatures, insofar as they exist, exist in and through God; but insofar as they are not existence itself, and are 'this' existent but not 'that' one, they are nothing in themselves. Hence, creatures have a sort of intermediate being (they are the 'isthmus' or barzakh) between God's pure, unitary existence and nothingness.

So far, we have encountered nothing unobjectionable to orthodox Islam. But Ibn 'Arabi carries the principle of wahdat al-wujud a step further than most Muslims and even most Sufis: he argues that insofar as we conceive of God as differentiated from creation, we do not conceive of God properly as God but only as 'Lord' ( $r a b b)$ of creation, as the greatest being among beings, but still as a mere being and hence, in a sense, as a creature. The goal of Ibn 'Arabi's mystical thought, then, is to 'deconstruct' this dualism inherent in traditional monotheism and to show how God is simultaneously immanent in, but also transcendent to, his creatures. In this scheme, all creatures become 'words' of God, manifesting some truth of the divine Essence. The prophets then draw these words together into messages accessible to mankind. Therefore, as 'Abd al-Hakeem Carney puts it, the goal of the realized knower or 'gnostic' is not to theorize about the origin of creatures nor even to have an ecstatic experience that goes 'beyond' them, but rather, to listen to the creatures themselves as divine words:

Mysticism, then, does not consist in seeking out ecstatic experiences that are beyond the pale of everyday life. Rather, it is based upon a kind of listening, whereby the gnostic pays attention to the discourse that is all around him but, hitherto, he has been heedless of. It is a matter of finding God in His immanence to Creation, which means taking the Creation as nothing less than a Divine communication, a discourse between God and humans that demands to be heard. ${ }^{7}$

For a Muslim mystic like Ibn 'Arabi, the prophet does not "mark the entry of God into history" so much as overturn "human beings' comfortable belief in

7 'Abd al-Hakeem Carney, "Imamate and Love: The Discourse of the Divine in Islamic Mysticism," Journal of the American Academy of Religion, 73/3 (2005): 707. 
the God/world dichotomy." ${ }^{\text {P }}$ Thus, the prophet illuminates the immanence of God's existence - the divine wujud — by being a living and breathing manifestation of God's word. He clarifies that God's word is not other than the creatures themselves, who exhibit the plenitude of God's Essence. But at the same time, as a man limited in space and time, the prophet also points to the truth that no creature is God and that no one creature can express the divine Essence completely.

Jesus illustrates this paradox better than any other prophet in Ibn 'Arabi's Bezels. In fact, Ibn 'Arabi asserts that Jesus was indeed a word of God (although just $a$ word) and that, moreover, he was a word analogous to the word given through Muhammad to the Muslim community (umma): "Gabriel was, in fact, transmitting God's word to Mary, just as an apostle transmits His word to his community (umma). God says, He is His word deposited with Mary, and a spirit from Himself." "As the direct word of God's spirit, Jesus was also able to raise or 'animate' the dead: "Jesus came forth raising the dead because he was a divine spirit. Thus, bringing the dead to life was attributed to him both actually (mutahaqiq) and notionally (mutawahim)."10 The two terms, mutahaqiq and mutawahim, are important here because they signify the dual nature of the prophet in Ibn 'Arabi's thought. Jesus raised the dead 'actually' (mutahaqiq) insofar as he was a direct manifestation of God (al-Haqq) and his power; he raised the dead 'notionally' (mutawahim), however, insofar as he and those he raised are all creatures analogous to a dream or a 'presumption' (=wahm) in relation to God. In this way, Jesus points to the instability of any absolute distinction between God and the world, while at the same time acknowledging his own creaturely nothingness.

Furthermore, Jesus's humility is a crucial factor to this destabilization of any absolute difference between God and the world. In Ibn 'Arabi's Sufi thought, Jesus' humility draws our attention to the utter 'poverty' ( fuqura) of creatures in the face of the 'richness' (ghania') of God's being. Creatures are 'poor' in that they are 'as if nothing' or 'having nothing' in comparison to God's absolute being. Accordingly, Ibn 'Arabi emphasizes Jesus's own poverty and humility right near the beginning of his bezel on Jesus. What is at first striking here are the political implications he draws from it:

The humility of Jesus was such that his community was commanded that they should pay the poll-tax completely, humbling themselves, that if any

\footnotetext{
$8 \quad$ Ibid., 714.

9 Austin, 175/Affifi, 139 .

10 Austin, 176/Affifi, 139-40.
} 
one of them were struck on one cheek, he should offer also the other, and that he should not hit back or seek retribution. This aspect [of his teaching] derives from his mother, since woman is lowly and humble, being under the man, both theoretically and physically. His powers of revival, on the other hand, derive from the blowing of Gabriel in human form, since Jesus revived the dead in human form. ${ }^{11}$

But almost immediately thereafter, Ibn 'Arabi brings the discussion of Jesus's humility and asceticism back to metaphysical issues, discussing how the humility and poverty of Jesus allow the divine spirit to work its animating power on creatures. Hence, the casual observer would see him as a 'mortal man performing divine acts:'

It used to be said of him, when he revived the dead, "It is he and yet not he (huwa la huwa)." Both the sight of the observer and the mind of the intelligent man were confused (wa taqa' al-hayra) at seeing a mortal man bring the dead to life, rationally as well as physically, which is a divine prerogative. The spectator would be utterly bewildered to see a mortal man performing divine acts. ${ }^{12}$

There are two terms or phrases here that are important in Sufi thought. The first is that Jesus manifested in a powerful way the truth that each creature is 'He and not He,' in other words, that each creature is in a way God ('He'), insofar as it derives all of its existence from God, but also that each creature is radically other than God, or 'nothing' ('not He'), inasmuch as the creature is bound and limited by both its form and matter. Thus, in his poverty and humility Jesus demonstrates that he is a creature, as he is utterly poor with respect to being; but insofar as in his creaturely nothingness he reveals divine power and raises the dead, he is a theophany - a manifestation of the divine Essence within created being.

11 Austin, 177/Affifi, 140. We perhaps find an echo here of the letter to the sultan of Konya cited earlier. At work here also may be the idea of Jesus as a model of irja' in the Sufi tradition. This is a term denoting an early Muslim movement which generally avoided becoming involved in civil wars and refrained from branding any Muslim an unbeliever because of doctrinal differences, provided faith in one God was not abandoned. Khalidi also notes that Ibn 'Arabi's representation of Jesus reflects the increasing tension between Sufis and legal scholars in his time. Jesus was conventionally inducted into this struggle on the side of the Sufis because of his perceived disapproval of narrow-minded legalism. See Khalidi, The Muslim Jesus, 35, 202. 
For Ibn 'Arabi, those who observed the miracles of Jesus were 'confused' or 'bewildered' by what they saw: a mere mortal performing divine acts. The term for 'confused' or 'bewildered,' hayra, is the second important Sufi term. Hayra refers to that 'stage' ( $\mathrm{hal}$ ) in which the dichotomy between the world and God as a distinct Lord collapses. It is therefore one of the highest stages in the Sufi quest, because it is here that the Sufi experiences God's simultaneous immanence and transcendence in himself and in all creatures. But, according to Ibn 'Arabi, the early Christians misinterpreted their bewilderment and mistakenly attributed divinity to the man Jesus, and so they speak of God's incarnation:

This matter has led certain people to speak of incarnation and to say that, in reviving the dead, he is God. Therefore, they are called unbelievers [concealers], being a form of concealment, since they conceal God, Who in reality revives the dead, in the human form of Jesus. He has said, They are concealers [unbelievers] who say that God is the Messiah, son of Mary. The real error and unbelief in the full sense of the word is not in their saying "He is God" nor "the son of Mary," but in their having turned aside from God by including [God in human form] in the matter of reviving the dead, in favor of a merely mortal form in their saying [He is] the son of Mary, albeit that he is the son of Mary without doubt. Hearing them, one might think that they attributed divinity to the form, making it the form itself, but that is not the case, having in fact asserted that the divine Identity is the subject in the human form, which was the son of Mary. Thus they distinguished between the form and the determination, but did not make the form the same as the determining principle. In the same way, Gabriel was in mortal form [at first] without blowing [into Mary]; then he blew [into her]. Thus the blowing is distinguished from the form, since, although it derives from the form, it is not of its essence. So do the various sects quarrel concerning the nature of Jesus. ${ }^{13}$

I cite Ibn 'Arabi at length here because this passage is central, I believe, to his and the entire Sufi and Muslim understanding of Jesus. The first thing to note here is that Ibn 'Arabi argues that calling Jesus the 'son of God' is neither incorrect nor blasphemy. As Carney explains:

The statement that Jesus is God is not blasphemy. It is, in fact, correct. Al-Qaysari [a medieval Muslim commentator on Ibn 'Arabi's Bezels] writes explicitly that the statement that Jesus is God is correct and true 
insofar as Jesus is a specific epiphanic manifestation of the Divine Being (al-haqq). And the statement that he is the son of Mary is true without any doubt. The act of disbelief, according to Ibn 'Arabi, is the union of the two statements, that is, that Jesus the son of Mary (meaning his nasut) is God. It is the confusion of the human nature of Jesus (symbolized by referring to him as the son of Mary) and the Divine that is the source of the problem, not the idea that Jesus as a theophanic being is identical to God. ${ }^{14}$

The mistake is therefore to confuse the limits or form of the manifestation of God with the divine manifestation itself. Carney then continues to explain:

The problem is not that Jesus is God; this is accepted on face value. The problem is rather that Jesus as a physical being is also a negation of God, because by bringing God out in a particular form (in the case of Jesus, a particularly high form), Jesus qua Jesus is a negation of God, that space in which the Manifest God may come into being. ${ }^{15}$

All finite essences and, a fortiori, all material or physical beings are thus seen as negations of the plenitude of God's Essence. Accordingly, Jesus manifests God and the divine Essence by his divine powers and acts made possible by his receptive humility, and yet he also negates that Essence by the finitude of his humanity and the particularity of his physicality. Ergo, Muslims properly understand Jesus as a mere man and prophet and not as the incarnate Son of God.

Moreover, as Carney points out, this tension between manifestation and negation in Jesus plays out in the reception of the divine word that Jesus manifests. This occurs because all particularity, in effect, alters and distorts the divine word, such that while the divine Essence is made manifest and revealed in the prophetic discourse, it is also distorted and even negated by the very particularity of that discourse:

14 Carney, "Imamate and Love," 716. As Mahmoud Ayoub observes in connection with this point: "Islam draws an absolute distinction between the creator and all created things. Yet ideas such as Ibn al-Arabi's wahdat al-wujud, 'unity of being', can easily accommodate notions of divine sonship" (Mahmoud Ayoub, A Muslim View of Christianity: Essays on Dialogue (New York: Orbis Books, 2007), 128).

15 Carney, "Imamate and Love," 717. 
It is not so much that the subject "reads" into the Divine discourse that which he wants to hear. It is rather the subject qua subject that causes this distortion. It is something implicit in the subject's very subjectivity, in his existence as a being that is simultaneously a sign and manifestation of the Divine discourse (for everything in the universe), and at the same time marks the entry of a fundamental negativity within the Divine being, as a not-God that assures him no other role except as servant ('abd) to the Divine being. This dual situation, these "two natures" (a union that exists in a non-hypostatic fashion) that are united inside the servant, is made clear in Ibn 'Arabi's description of the universe as Huwa/La Huwa, "Him, not Him."16

Hence, Jesus's first followers by necessity misunderstood him and attributed divinity to his human nature and to his individual particularity. In other words, the early Christians did not understand that Jesus was both 'He' and 'not He.' Nevertheless, this was understandable given that Jesus, according to the Qur'an itself, had no human father:

Thus he is [at once] the Word of God, the Spirit of God, and the slave of God, and such a [triple] manifestation in sensible form belongs to no other. Every other man is attributed to his formal father, not to the one who blows His Spirit into human form. God, when He perfected the human body, as He says, When I perfected him, blew into him of His spirit, attributing all spirit in man's being and essence to Himself. The case of Jesus is otherwise, since the perfection of his body and human form was included in the blowing of the spirit [by Gabriel into Mary], which is not so of other men. All creatures are indeed words of God, which are inexhaustible, stemming as they do from [the command] $B e$, which is the Word of God. Now, can the Word be attributed to God as He is in Himself, so that its nature may never be known, or can God descend to the form of him who says $B e$, so that the word $B e$ may be said to be the reality of the form to which He descends and in which He is manifest? Some gnostics support the former, some the latter, while others are confused and do not know what is the truth of the matter. ${ }^{17}$

In this scheme of things, any word from God both reveals God and at the same time (and to the same degree) conceals or even negates the divine word.

16 Carney, "Imamate and Love," 709.

17 Austin, 178/Affifi, 142. 
As explained above, this problem applies not just to 'prophetic words' but to all creatures, since all creatures are words of God. However, Ibn 'Arabi leaves this matter an open question, simply saying that it can only be resolved by 'taste' (dhawq) or 'direct experience.'18 What might this 'taste' that resolves the matter tell us?

As Ibn 'Arabi continues to explain in his bezel on Jesus, we must conceive of the universe and all its forms as being received, as it were, into the Divine Breath as their Primordial Substance, which is Nature herself. ${ }^{19}$ This Breath makes manifest the divine Names, which otherwise remain hidden in the divine Essence, for the divine Names materialize only in their relation to creatures (such as the 'Merciful' or the 'Exalted'). The Essence in itself, however, is beyond these Names and their 'conflicts' (because the Names often indicate attributes that to our limited view seem to be in conflict, such as the 'Avenger' and the 'Merciful'). ${ }^{20}$ Ibn 'Arabi points this out only to make a comparison between the universe (the macrocosm) and the individual soul (the microcosm):

Whoever wishes to know the divine Breath, then let him [first] know the Cosmos, for "Who knows himself, knows his Lord," Who is manifest in him. In other words, the Cosmos is manifested in the divine Breath by which God relieved the divine Names from the distress they experienced by the nonmanifestation of their effects. Thus He bestows favor on Himself by what He creates in His breath. Indeed, the first effect of the Breath is experienced only in the divine Presence, after which it continues its descent by a universal [process] of release, down to the last thing to be created. ${ }^{21}$

So in the individual human being, the divine Essence is paradoxically manifest in the non-manifest consciousness, or internal witness, that makes all aware-

18 Affifi, 141.

19 "The Reality describes Himself as the Merciful Breath, and that all that attaches to an attribute, in the case of something described, should adhere to that attribute. You know that the breath in one breathing is all that needs to be. Therefore, the Divine Breath is receptive to cosmic forms, in relation to which it is like the Primordial Substance, being very Nature Herself" (Austin, 179-80/Affifi, 143-44).

20 "Indeed it is the Breath that has brought about the mutual conflict among the divine Names, which are relationships. Consider, however, how the divine Essence, which is beyond this regime [of conflict], is characterized by [utter] Self-sufficiency, beyond all need of the Cosmos. Because of this the Cosmos has been set forth in the form of its Creator, which is nothing other than the divine Breath" (Austin, 180/Affifi, 144). 
ness possible. This internal witness is constituted by the awareness of the unity of all being or existence as such, and so it is in this internal witness that being or existence is 'found' (mawjud — 'is found' or 'exists') as such. ${ }^{22}$ In this way, Ibn 'Arabi extends his destabilization of the God/world dichotomy even further, so that it includes God and the human individual:

[So I said], Worship God. He uses the name Allah because of the variety of worshippers in their acts of worship and the different religious traditions. He does not use one of the particular names, but rather that Name which includes them all. Then he goes on to say, My Lord and your Lord, whence it is certain that His relationship with one creature, as Lord, is not the same as with another. For that reason he makes the distinction between My Lord and your Lord, referring separately to the speaker and the one spoken to. ${ }^{23}$

God is both immanent in and transcendent to the soul. Accordingly, 'Lord' $(\mathrm{rabb})$ is a term that applies to God when the soul regards God as an object over and against itself, taken in its creaturely finitude and material particularity. But insofar as the soul is conscious of the unity of being, then the boundary and distinction between it and God is fluid and even illusory. No other prophet demonstrates this fluidity for Ibn 'Arabi better than Jesus:

He continued, And when You caused me to die, that is, when You raised me to Yourself, hiding them from me and me from them, You were the watcher over them, not in my material substance, but in theirs, since You were their sight, which required supervision. Man's consciousness of himself is indeed God's consciousness to the name, the Watcher, referring the consciousness to Him. He wishes thereby to distinguish between himself and his Lord, so that he may know that he is himself, a servant, that God is Himself as his Lord, considering himself as witness and God as the Watcher. Thus, in relation to himself, Jesus puts his people first, saying, concerning them a witness, while I am with them, preferring them out of courtesy. He places them last, however, when speaking of God in saying, the Watcher over them, since the Lord is deserving of precedence. ${ }^{24}$

As Peter Coates comments: "For Ibn 'Arabi consciousness of the Self, in its metaphysical depths, is nothing less than consciousness of the Unity of Being" (Peter Coates, Ibn Arabi and Modern Thought (Oxford: Anqa Publishing, 2002), 172). 
Thus, Jesus epitomizes the hadith that states that in the servant who loves God with a pure love, God becomes his 'hearing' and his 'seeing' and his 'walking.'25 God in such a 'knower' (gnostic or 'arif) 'animates' the knower's every act and is, therefore, the 'observer' or 'watcher' (shahid) that grounds every act of awareness and knowing. Furthermore, it is in awareness of this fundamental awareness that the soul comes to 'taste' God as the Watcher (shahid) within.

Ibn 'Arabi is fond of quoting his great Sufi predecessor, Junayd, who used to say about knowledge (ma'arifa) and the knower ('arif): "The water takes on the color of its cup."26 That is, the knowledge that the Sufi has of God (the water) is colored by conditions of his creaturely finitude. We cannot, however, do without the cup, since it is by means of the cup (the sacred text, the sacred tradition) that the water (divine knowledge) becomes accessible to the created intellect. We can only attain divine knowledge, therefore, by taste (dhawq), i.e., by drinking the water in the cup. But a pure, undistorted knowledge of the divine Essence as such (the water as it is devoid of color outside the cup) is impossible. Ibn 'Arabi extends this notion to understand religion itself: thus, the different religions (adyan-din, sing.) take the shape of many different cups, each holding the water of divine knowledge, even though Islam is the clearest and most capacious cup. In this analogy, every religion or din (law) is a 'cup' that 'colors' its view or notion of God (which Ibn 'Arabi calls the 'God of belief,' as opposed to God himself in his hidden Essence). Thus, the Sufi solution to Muslim-Christian dialogue (or, more narrowly, Ibn 'Arabi's solution) is to approach the two religious traditions as two cups out of which the divine Essence may be drunk and tasted, but in which knowledge of God as such eludes the soul, due to its inherent finitude and the historically limited nature of human tradition.

25 Austin, 184/Affifi, 148.

26 Ibn 'Arabi expands upon the saying of Junayd in Meccan Revelations: "Junayd was asked about knowledge (ma'arifa) and the knower ('arif). He replied 'The water takes on the color of its cup'. In other words, the container displays its effects in what it contains. Junayd said this to let you know that you will never judge your object of knowledge except by yourself, since you will never know anything but yourself. Whatever may be the color of the cup, water becomes manifest in that color. The person without knowledge judges that the water is like that, since sight gives that to him. Water discloses itself in the forms of all the cups in respect to their colors, but it does not become delimited in its essence. You only see it that way. In the same manner, the shapes of the containers in which water appears display their effects in it, but in all of them it is still water. If the container is square, the water becomes manifest as square" (Al-Futuhat al-Makkiyya, III, 161.24, translated by William Chittick in The Sufi Path of Knowledge (Albany, NY: State University of New York Press, 1989), 341). 
There is, however, a problem inherent in this solution, as attractive as it might be to the modern mind. Such a solution depends upon an understanding of Jesus, and of divine knowledge in general, that is fundamentally gnostic (in the late antique Hellenistic sense of the term). Here, materiality and created finitude are insurmountable obstacles to knowledge of the divine, and so we must conceive of the knower (or Knower, God) not only as pure spirit, but also as spirit that is purified from matter and finitude and thus totally beyond the human condition as such. Not only is this assertion something any knowledgeable Christian cannot accept, but it also leads to a tension, maybe even a contradiction, internal to Ibn 'Arabi's own speculative Sufism: it asserts a fundamental and insurmountable duality in a system whose entire goal is to surmount or at least destabilize all dualist thinking. Material individuality and the finitude of the creaturely essence can therefore be recognized and relativized in relation to the Sufi's awareness of the oneness of the divine Essence, but they can never be wholly overcome. So, while we can destabilize the God/ world and God/soul distinctions in human language, these distinctions remain insurmountable in reality.

\section{Jesus as the 'Negation of Negation' in Meister Eckhart}

To make clearer what is at stake for Muslim-Christian dialogue, it will be helpful to look at the thought of a Christian mystic close to Ibn 'Arabi not only in time, but also in the fundamental outlines of his mystical thought. Meister Eckhart is such a mystic. The way he appropriates the Christian tradition in the service of a mystical reading of scripture is analogous to Ibn 'Arabi in striking ways. ${ }^{27}$ Like Ibn 'Arabi, Eckhart attempts to disrupt and go beyond any fixed God/world and God/soul dichotomy, thus opening up an understanding of God and his Word that sees their identity in difference and immanence in transcendence. Eckhart himself even talks of a 'God beyond "God," ' meaning not the remote god of ancient Gnosticism but, on the contrary, the living God who is the ground of our very being, knowing, and willing. Indeed, in one of his vernacular sermons, Eckhart asks his hearers to pray to God that we might be free of God, where God is understood as a being distinct and separate from us who is only one being among other beings (even if the greatest or first). With this, we find a way of thinking that is very similar to Ibn 'Arabi. Eckhart also

27 For a much fuller comparative analysis of the mystical thought of these two thinkers, see my book Logos and Revelation: Ibn 'Arabi, Meister Eckhart and Mystical Hermeneutics (Washington, DC: Catholic University of America Press, 2010). 
asserts the 'nothingness' of creatures in comparison to God, claiming that creatures are utterly poor with respect to God, and derive all of their being, oneness, truth, and goodness from God. Thus, for Eckhart, Existence (esse) Itself is God, and creatures are but negations of that pure, unrestricted Existence. ${ }^{28}$

Eckhart, however, goes further. In his thinking, the negativity of the creature is not an absolute barrier between God and man. This is because we cannot logically stop at the mere negativity of the creature or at God's absolute existence, since this would reinforce the duality that he strives to break. Thus, on a higher plane, we must also conceive of God as the negation of negation (negatio negationis), which is simultaneously the purest affirmation of being or existence. Since pure existence (Existence in Itself) is God, God is also the negation of all that may limit or deny existence, which does not, however, deny the limited, individual existence of creatures as existents:

But to existence itself no existence is denied, just as to animal itself is not denied this animal, for example, "lion." Therefore, no negation, nothing negative, belongs to God, except the negation of negation which is what the One signifies when expressed negatively.... The negation of negation is the purest and fullest affirmation - "I am who am" ... Existence cannot deny that it is Existence Itself. ${ }^{29}$

What is important here is that Eckhart asserts that the negation of negation as found in God's utter unity is also a pure and full affirmation. No existence-not even limited, finite, material existence — can be denied to God, if God is indeed the fullness and perfection of Existence Itself. So, just as 'lion' cannot be denied to the category of animal itself, no limited, finite creaturely existence can be denied to God. Of course, this does not mean that God is indistinct from all creatures or that creatures and God are simply one and the same; rather, creatures are radically distinct from God precisely insofar as they are negations of pure existence, but not negations of that negation. Nevertheless, Eckhart argues that no negation as such is or can be absolute; it exists only to be negated in God's purity of being and oneness.

28 See Eckhart's prologues to his Opus Tripartitum, found in Meister Eckhart: Die Lateinische Werke, Vol. I (Stuttgart: Kohlhammer Verlag, 1936- ), 148-84 (henceforth LW); translated in Armand A. Maurer, Master Eckhart: Parisian Questions and Prologues (Toronto: Pontifical Institute of Medieval Studies, 1974), 77-105.

29 In Exod., n. 74 in LW, Vol. II, 77; translated in Bernard McGinn, Meister Eckhart: Teacher and Preacher (Mahwah, NJ: Paulist Press, 1986), 68. 
This dialectic of the 'negation of the negation' holds for the human being as well, and his or her relationship to God. Human nature does not erect an insurmountable barrier between man and God (as was posited by Ibn 'Arabi), but actually opens up the possibility of unity by the very fact that human nature, as both material and spiritual, as embodied yet open to the universality of being by virtue of its intellectual nature, is able to become a locus of the divine negation of negation. And, to the extent that the human soul is capable of freedom from the material conditions of existence by virtue of its intellectual nature, human nature is capable of being assumed by the divine nature in such a way that human nature as such is affirmed in the hypostatic unity of Christ:

Man is an accident of nature. Therefore, abandon everything that is accident in you and preserve yourself as free, undivided human nature. Since this same nature which you possess has become the Son of the eternal Father through its being assumed by the eternal Word, you become the Son of the eternal Father with Christ because you have the same nature which has become God. Therefore, be careful not in the least to hold onto yourself as you are this person or that, but preserve yourself as a free, undivided human nature. And so, if you want to be one Son, separate yourself from all nothing because nothing causes distinction. How is that? Note the following. That you are not a certain person, it is the not which differentiates you from this person. If you want to be without distinction, rid yourself of not (nihte). There is a power in the soul which is separated from nothing since it has nothing in common with any things. Nothing is in this power but God alone. He shines naked into this power. ${ }^{30}$

It is not materiality or finitude that prevents the union of the human soul with Christ — for Christ had assumed both—but rather, it is the soul's attachment to that materiality and finitude. For Eckhart, Christ points the way (through his Incarnation and his death on the cross) to this negation of negation, in which God and world, as well as God and soul, become one without becoming the same. Insofar as we love our neighbor in self-sacrifice, we dwell in our 'undivided' human nature, which is nothing other than the undivided divine nature as well, for human nature in its purity (Christ) is nothing other than the divine nature itself. ${ }^{31}$ Hence, in Eckhart's mystical thought, creaturely finitude and

$30 \quad$ Predigt 46 in LW, Vol. II, 380-82; translated in McGinn, Meister Eckhart, 304-05.

31 Dobie, Logos and Revelation, 154. 
material individuality are united to God and can be united to God insofar as our human nature is redeemed. Our knowledge of this redemption, furthermore, cannot come from the powers of reason alone, but can only be revealed in the birth, death, and resurrection of Christ. ${ }^{32}$ Nevertheless, the powers of human reason and human language are also redeemed, insofar as Christ is the incarnate Word of God. As incarnate Word, Christ not only fully manifests God's presence, but he also takes up and negates the negation of finitude and materiality through the communication of the divine Word, thus making both finitude and materiality fitting vehicles for God's full self-expression. In this way, the soul's intellectual nature is also fulfilled, because it is the nature of the intellect to be "separated from nothing since it has nothing in common with anything." Accordingly, the play of revelation and concealment that we saw with the divine words in Ibn 'Arabi is overcome.

We therefore go 'beyond' the 'God' of creation, to the extent that we see God has united himself essentially and completely to our human nature in Christ, so that what is fully human is also fully divine, and what is fully divine is not alien to anything that is fully human — materiality and finitude included.

For Eckhart, the fact of the Incarnation contains the inner truth of Christianity. The Incarnation tells us that God in the person of Christ did not think 'divinity something to be held onto' but that he 'emptied himself' by becoming a human being (Phil 2:6-8). By doing so the eternal breaks into historical time and abiding truth into the world of shifting phenomena. $^{33}$

Furthermore, the breaking of the eternal into the temporal, the uncreated into the created, and the divine into the human, are all expressed by Meister Eckhart in terms of birth - the birth of the Son into the soul. In this incarna-

32 As Mahmoud Ayoub points out, Islam has no conception of sin and redemption: see his A Muslim View of Christianity, 137. Thus, in Islam in general, and the Sufi tradition in particular, Jesus becomes only an example of piety, love, and asceticism, which is to be emulated. Christ also exemplifies a fulfilled humanity, a humanity illumined by the light of God. This reflection of the divine light in the human heart and soul is known in the language of Islamic mysticism as tajalli, the manifestation of divine beauty and majesty in and through man (Ayoub, A Muslim View of Christianity, 152). Nevertheless, according to Islam and even the thought of someone like Ibn 'Arabi, who was unafraid to stretch doctrinal points, human and divine nature always remain distinct and separate. Thus, as prophet, Jesus can do nothing to affect any unity between God and human beings-he can only be an example or point to the way, not be the way itself. 
tional language of 'birth,' God becomes the lived ground for knowledge, will, and action in the soul where this 'event' has occurred. In this event, any radical dichotomy between word and God or soul and God is abolished; however, in the very act of birth, the materiality and individuality of the believer is also affirmed. In this sense then, it is the affective fulfillment and perfection of the 'negation of negation.'

\section{Ibn 'Arabi, Meister Eckhart, and Interreligious Dialogue}

As noted above, the thought of a Christian mystic like Meister Eckhart has features strikingly similar to that of a Muslim Sufi like Ibn 'Arabi. They both attempt to draw the believer into a deeper appreciation of the 'identity in difference' and 'difference in identity' between God and the world on one hand, and God and soul, on the other. They both do this by pointing to a conceptual difference between God as he is in his Essence, utterly one in himself and with all things (immanent in his transcendence), and God as 'Lord' of creation, as a being distinct and apart from his creation. These, of course, are not two different 'gods,' but one and the same God viewed from different angles, though the first perspective for both our mystics is clearly more adequate and comprehensive than the second. Furthermore, Ibn 'Arabi and Meister Eckhart use similar strategies to effect this shift in perspective for their hearers and readers: both stretch language to the limit, engage in what appears to be blasphemy, and often read sacred texts against themselves. But, as we have pointed out above, there are limits to this convergence. The most important limit is in the notion of redemption, which is totally absent from Islam and thus from the mystical thought of Ibn 'Arabi as well. Thus, while a Christian mystic like Meister Eckhart might find much to appreciate in the writings of Ibn 'Arabithe unity and oneness of God, his immanence in transcendence, the importance of the biblical prophets - he would find it jarring that there is a lack of any notion of the Fall, the Incarnation, the atoning sacrifice of the Cross, and our redemption. For Eckhart, it is precisely this redemptive character of Christ that completes the dialectic of God's immanence in transcendence, which we found only partially complete in Ibn 'Arabi's thought.

If, however, a proper appreciation of difference is the foundation of genuine interreligious dialogue, then our two mystical thinkers have laid the groundwork for this very well indeed. 



\section{Index of Names and Terms}

\author{
Abdallah ibn Salam $\quad 37,39-47$ \\ Abraham 179, 181, 197, 207, 209-210 \\ Abū Ḥanīfa 223-224 \\ Abū Hurayra 191, 219 \\ Abū Rā’ița al-Takrīīī $\quad 216$ \\ Alan of Lille $\quad 6,105,107$ nn. 2-3, 108, 116 \\ Al-'Aqqad, 'Abbas 199-200 \\ Al-Dajjal 191-192 \\ Al-Fārābī $\quad 227$ \\ Al-Ghazali, Abu Hamid 194 \\ Al-Ḥallāj 233 \\ Al-Husayn $\quad$ 197-198 \\ 'Ali $\quad 197-198$ \\ al-ihsan 186 \\ Al 'Imran 40, 184 \\ Al-Masih, 'Isa 179 \\ Altaner, Berthold $\quad 168$ n. 30 \\ Al-Wahidi 44 \\ Amadis de Gaule 174 \\ Arabic language $\quad 162$ \\ Armenians 108 \\ Augustine $59,70-71,73$ n. 34, 81-83, 96, 119, \\ 121,156
}

Baghdad 106, 113, 119, 125, 136

Baldini, Ugo 173 n. 53

baptism 58, 94, 101, 105, 109-110, 112, 116, 120

Bartoli, Daniello $\quad$ 169, 172

Bartolomeo Piceno de Montearduo 130

basmala 116-117

bātin (hidden) 220-221

Bellitto, Christopher M. 49 n. 3

Bessarion, Basilios 123 n. 1, 142

Bibliander (Theodor Buchmann) 37

Biechler, James E. $\quad 1,21,37-38,56$ n. 34, 64 n. 72,69 n. 5,82

Bisaha, Nancy $\quad 123,129$ n. 28, 139

blasphemy $\quad 162,164,170-171,241,251$

Blum, Paul Richard $\quad 6,89$ n. 12,

Boethius 76, 99

Bonner, Anthony $160 \mathrm{n} .2$

Bovelles, Charles de $\quad 165$

Boyle, Marjorie O’Rourke 168 n. 31
Broderick, James 175 n. 63

Burman, Thomas E. 5,46 n. 45,121 n. 64,123 , $125,143,144$ n. 85,147

Calderón de la Barca, Pedro 170

Câmara, Louis Gonçalves da 168 n. 32

Candellero, Massimo 162 n. 8

Carrèras y Artau, Tomás and Joaquin 163 n. 11

Cathars 107-108, 110

Cervantes, Miguel de 174

Christianson, Gerald $11 \mathrm{n} .14$

Christology $\quad 5^{-6,53}, 54$ n. 20, 55-56, 59, 69, $75-76,78-80,84-85,102,162,164$

circumcision $\quad 58,105,108-109,112-113$, $118-120$

Classen, Joachim Carl 132 n. 40

Constantinople $2,10,17,20-22,30-31,34$, $39,49-51,68,70,74,88$ n. $6,111,113$ n. 32, 132-135, 145

Corsi, Giuseppe 127 n. 17

Cribratio Alkorani $\quad$ 1, 6, 10, 12-15, 18, 20-21, 23, 27-29, 33-39, 45, 47, 51, 61, 71-72, $76-77,95,111,124,135^{-136,138-139}$

Daiber, Hans $\quad 164$ n. 16

Daniel, Norman 34 n. 13

De docta ignorantia $6,18,24,51,53-55$, 59-6o, 63, 73, 97

De pace fidei $1-3,6,10,12-13,15,18,20-27$, 29-35, 37-39, 48, 51, 54, 57 n. 41, 58-63, $68-72,73$ n. $34,74-85,88,95,97-98,107$, $111,113,137-138$

devshirme $\quad 151$

Domínguez Reboiras, Fernando 162 n. 6 Dougherty, Michael 166

Eckhart $\quad 235^{-251}$

Ecumenical Councils 76

Erasmus of Rotterdam 170

Eschatology 204, 208

Ethiopian Orthodox 113

Euler, Walter Andreas 86 n. 1, 88 n. 7, 113 n. 31,163 n. 12 
Ficino, Marsilio $\quad$ 124, 135, 139

Francis of Assisi 175 n. 66

Friends of God 196-197

Gabriel (Angel) 42-43, 45, 180, 182, 186, 209, 237, 239-241, 243

Gaeta, Franco 132 n. 40

Gautier, Léon 174 n. 57

Gayà, Jordi 161 n. 4

George of Trebizond 124, 129, 132-134, 142

Gilbert Crispin $\quad$ 108, 111, 121-122

Ḥasan al-Basrī 232

Hadith $42-43,47$ n. 48, 117 n. 48, 191-192, 200, 204-205, 218-219, 223, 246

Hagemann, Ludwig $\quad 12$ n. 20, 14, 16-18, 38-39

Hanafi 116, 223

Hankins, James 124 n. 4

Hermann of Dalmatia $\quad 36,38-40,45-46$

Hick, John 31

Hunt, Lynn 173 n. 53

Ibn 'Abbas $\quad 185$

Ibn 'Arabi $\quad$ 5-6, 196-197, 236-242, 244-247, 249-251

Ibn Ḥazm 4, 220, 222-227, 229-230, 233

Ibn Hisham 40, 194

Ibn Ishaq 40

Ibn Kathir $\quad 43-44$

Ibn Masarra 221

Ibn Sīnā 227

Ibn Taymiyya 221 n. 8, 225, 227, 230

Ignatius of Loyola $\quad 5^{-6,160-161,168}$

Incarnation $29,52-54,59-60,72,74,80,98$, 108, 155, 158, 164, 186-187, 193, 205, 209, 212, $233,241,249-251$

Isa ibn Maryam (Jesus son of Mary) 4 n. 13, 6, 62 n. 63, 89-91, 157, 179-201, 219, 230, 241-242

Islam $1-4,6,9-10,12-14,16-24,26-27$, 29-31, 34-37, 39-40, 42-44, 46-47, 51, 56 n. 33, 6o, 63, 67-69, 71, 76-8o, 83-85, 88 nn. 6, 9, 89, 92, 94-95, 102, 105-106, 109, $111,113,114$ n. 37, 116 n. 45, 117, 120-132, 134-135, 136 n. 56, 137-138, 141-143, 145-152, $155,179,180$ n. 2, 181 nn. 3-4, 183-184, 189-190, 193-194, 197, 199-205, 207-208, 211, 213, 215-216, 219, 221, 223, 225, 229 n. 32, 233-234, 236, 238, 246, 250 n. 32, 251
Izbicki, Thomas M. 88 n. 9, 153

Izzi, Pierangela 128 n. 19

Jacob, Margaret C. 173 n. 53

Jacobites 107, 113

Janissaries $\quad 151$

Jean Germain 145 n. 1, 146, 147 n. 9, 150

Jews, Judaism $\quad$ 105-113, 119-122

John of Damascus 20 n. 1, 216

Johnston, Mark D. 161 n. 5, 168 n. 30

Juan de Segovia $\quad 6,9,145,147$ n. 9, 150-151

Judah Halevi 46

Judaizing 110, 113, 120

Ka'ba 194

Karbala $\quad 197-198$

Khalid, Muhammad Khalid 200

Khalidi, Tarif $\quad$ 193, 201, 240 n. 11

Kianka, Frances 129 n. 29

knighthood $\quad 172-173,175$

Kristeller, Oskar Paul 139 n. 71, 140 n. 73

Kydones, Demetrius $\quad$ 124, 129, 130 n. 32, 131 n. 38,134

lafza, pl. alfäz (word) 223-224

learned ignorance $33,75,79$

Leturia, Pedro 169 n. 34, 170 n. 41

Llinàs Puente, Carles 163 n. 11

Logos $69,71,76,80,85,88$ n. 8,186 n. 18,187 , 197

Lull, Raymond $\quad 160$ n. 1, 161-168, 171-172, 174 n. 57

Mallette, Karla $\quad 127$ n. 18

ma'nā, pl. ma'ānī (meaning) 213, 218

manuductio $\quad 23,95,98$ n. 55

Mary 6, 24, 28 n. 28, 62, 89-91, 157, 161, 170, 174 n. 57, 175, 180-193, 206, 219, 230-231, 237, 239, 241-243

Maryam (see Mary)

masa'il (questions) 39

Mazzucchi, Carlo Maria 134 n. 53

Mecca 27 n. 27, 194, 223

Mercati, Giovanni 129 n. 29, 130 n. 30

Mérigoux, Jean-Marie 114 n. 33, 125 n. 7, 130 n. 30,134 n. 51,136

Meserve, Margaret 123 n. 3

Meuthen, Erich 10 n. 7,38 n. 23, 39, 50 n. 5 , 145 n. 2,149 n. 23 
Mijnhardt, Wijnand $\quad 173$ n. 53

mikveh (Jewish ritual washing) 105,120

Monfasani, John 132 n. 40, 133, 135

monotheism 45, 51-52, 55, 57 n. 41, 6o-61, 94, 97, 100, 179, 207, 238

Montserrat $\quad 161,168-169,171,173-174$

Moors 162 n. 6, 169

Moriscos 169 n. 36

Mosul 114, 118

Mother of the Book (Umm al-Kitāb) 209-210

Muḥammad (Prophet) 37, 39-40, 43 n. 35, 180, 191, 194, 198, 200, 219

Muslims (see also Saracens) 2, 4, 6, 15, $17-19,23-25,28,35-36,41-42,44,46,49$, 56 n. $32,57,59$ n. 51, 61-63, 68-69, 72, $83-85,87$ nn. 2-3, 88-89, 94-95, 98-99, 105, 107-108, 110-112, 114-121, 124-126, 130-131, 134-136, 138-161, 164 n. 17, 167-168, 170, 173, 175, 179-180, 190-191, 194, 197, 200-202, 205-206, 209, 213 n. 19, 218-219, 225, 231, 233, 235, 236 n. 3, 236 n. 3, 238, 242

Nederman, Cary J. 123

Nestorians 107

Nicholas of Cusa $\quad 2,4$ n. 12, 12, 20-27, 29-34, $36-40,45,47,49$ n. 1,65 n. 75, 68, 69 n. 6 , 75 n. 49, 85-86, 88, 98, 100, 105, 111-113, 121 n. $63,136-139,145$

niyya (intention) 220, 223, 229

Obermeier, Anita $\quad 161 \mathrm{n} .4$

Olesh, Andrew 175 n. 66

Olshki, Leonardo $\quad 127$ n. 18

Peers, E. Allison $\quad 165$ n. 19

Pertusi, Agostino 134 n. 53

Peter the Venerable 10, 36-37, 39, 107, 109

Petrus Alfonsi 114 n. 36-37, 116, 121

pia interpretatio $\quad 14-15,27,95,137$

Piccolomini, Silvio Enea 14 n. 29, 123 n. 1, 135 n. 54, 146

Piemontese, Michele Angelo $\quad 123$ n. 3, 139

Platzeck, Erhard Wolfram $\quad 161,165$

Plethon, Gemisto George 129, 142

Pliny the Elder 128

Polonio, Martin 128

Pontanus, Jacobus $\quad 170,171$ n. 44
Preserved Tablet, see Mother of the Book (Umm al-Kitāb)

Proclus 97

Pseudo-Methodius $\quad$ 133, 135

Quesnel, Pierre $\quad$ 173-174

Qur'an 1-2, 4-6, 9-10, 13-16, 18, 20-21, 24-31, 33-39, 41, 43-45, 56 n. 32, 57, 59 n. $51,61-63,67,72,74,83,86,89-90,95$, 109, 111,115 n. 40, 116 n. 45, 117-118, 121-122, 124-129, 134-135, 137-141, 143-148, 150 n. $28,154-155,158,179-184,186-189$, 191, 199, 203-219, 222-223, 229, 231, 235-237. 243

Rābi'a al-'Adawiyya 232

Ramon Martí 114 n. 37, 119, 121

Ravegnani, Giorgio 132 n. 40

Raymond of Sabunde 99

Reiss, Edmund 142

religio una in rituum varietate $30 \mathrm{n} .1$, 32 n. $6,38,40,49,60,64$ n. 72, 71-73,

111 n. 24

revelation (of Qur'ān) $\quad 216$

Ribadeneira, Pedro 169

Riccoldo da Montecroce 4, 6, 37 n. 20, 106,

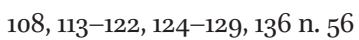

rite $\quad 5^{8-59}, 81,112,153$

Rizzardi, Giuseppe 125 n. 9

Robert of Ketton 9, 14, 20-21, 37-38, 109

Ryder, Judith R. 130 n. 29-30, 131 n. 33-35

Ševcenko, Ihor 130 n. 29

shirk 90-91, 95, 99

Sira 204-205

slaves 150

Smith, Wilfred Cantwell $\quad 31,82$

Suárez, Francisco 170

Sufism (Islamic mysticism) $\quad 232$

Supersessionism 180 n. 2, 217

Tabdīl 214-215, 221 n. 8

Tahriff (corruption of scripture) 213

Talmud 119

Tartars (Mongols) 10, 107, 108 n. 6

theology of religion $\quad 22-29,30-31,47-48$,

$54-60,63-67,84,98,122$

Thierry of Chartres $\quad 97$

Thomas Aquinas $12,96,130,170$ 
Tolan, John Victor 3 n. 9, 127 n. 18, 147 n. 13, 151 n. 36,175 n. 66

Toledan Collection $\quad 31,37-39,45,109$

translation (of Qur'an) 2, 5, 9-10, 14-15, 20, 24-25, 37-38, 43, 109

Trinity $13,23-24,29,52-55,57,59-62,66$, $72,86,88-92,94-99,102,108,110,126$,

134-135, 155, 158, 205-206, 212, 216, 219, 231

uns (intimacy) 232

Valkenberg, Pim 36 n. 16,46 n. 42, 136 n. 56, 137 n. 66,138 n. 67,235 n. 1

Vasoli, Cesare 139 n. 71

Vega, Amador 162 n. 8
Villani, Filippo 127 n. 18

violence $32,49,63,67,70,74,84,87,111,126$, $128,131,136,139^{-140}, 165^{-167}, 175^{-176}$

virginity 161,170

Volf, Miroslav 30,68 n. 1

Waldensians 107-108

Weiss, Roberto 134 n. 53

Wisdom Word 69, 83

wudu (Muslim ablutions before prayer) 109-110

zāhir (apparent) 220

Zāhirī school 220

zeal $32,165,172$ 